WBS: 1.2.2.3.3

QA: L SCPB: N/A Cover Sheet Page 1 of 3

Civilian Radioactive Waste Management System MOL . 19961202.0030 Management and Operating Contractor

\title{
SPENT NUCLEAR FUEL EFFECTIVE THERMAL CONDUCTIVITY REPORT
}

Document Identifier BBA000000-01717-5705-00010 REV 00

July 11,1996

Prepared for:

U.S. Department of Energy

Yucca Mountain Site Characterization Project Office

P.O. Box 98608

Las Vegas, NV 89109-8608

Prepared by:

TRW Environmental Safety Systems, Inc.

101 Convention Center Drive

Las Vegas, NV 89109

Under Contract Number Contract \#: DE-AC01-91RW00134 


\section{PREPARED BY:}
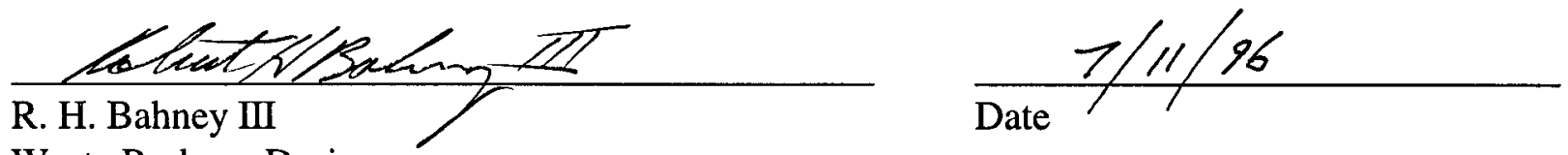

Waste Package Design

CRWMS M\&O, Nevada Site
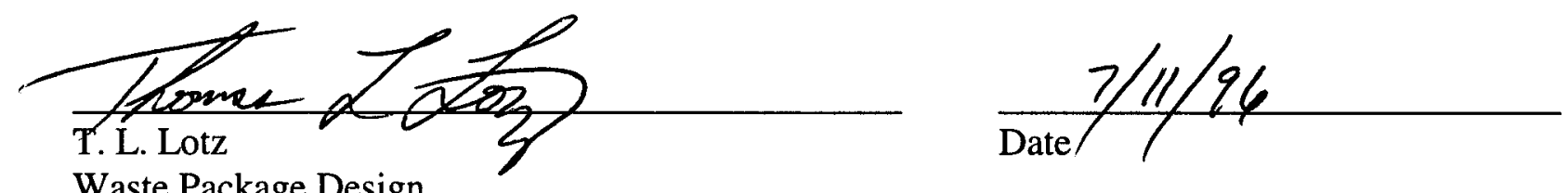

Waste Package Design

CRWMS M\&O, Nevada Site

APPROVED BY:

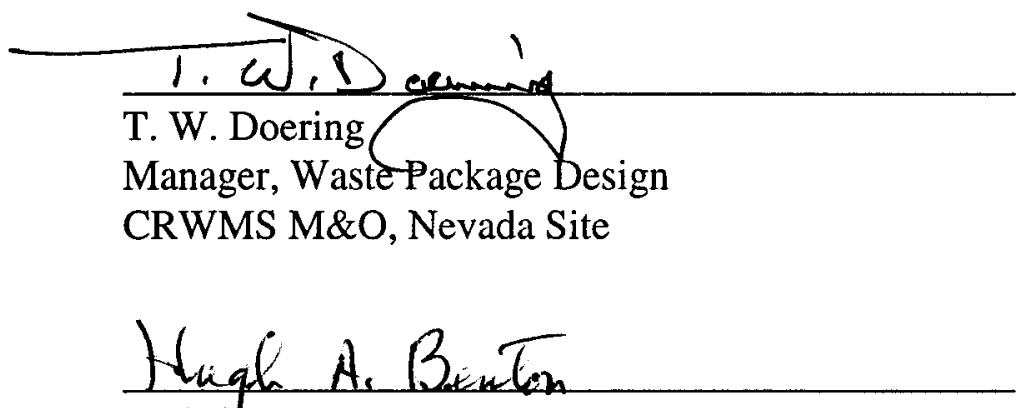

H. A. Benton

Department Manager, Waste Package Development

CRWMS M\&O, Nevada Site

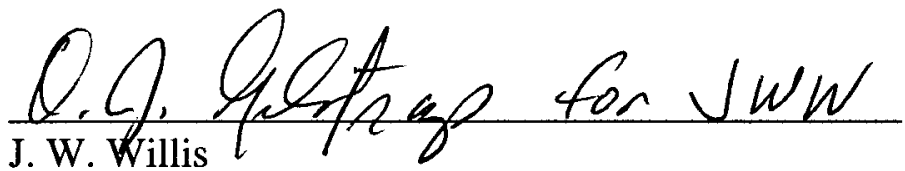

Manager, Quality Assurance

CRWMS M\&O, Nevada Site

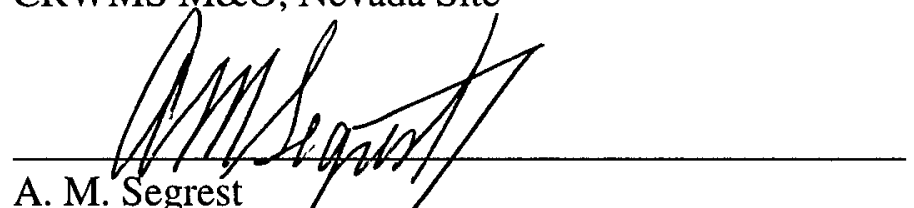

A. M. Segrest

Manager, MGDS Deyelopment

CRWMS M\&O, Nevada Site

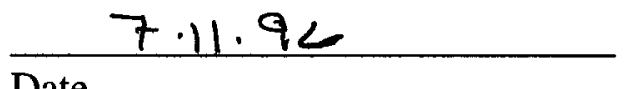

Date

$7 / 11 / 96$

Date
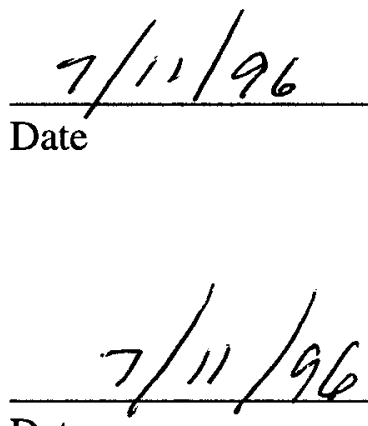

Date 


\section{REVIEW SIGNATURES}

The following individuals performed the Technical Document Review required by QAP-3-5, Section 5.3.2 through 5.3.7. Their signatures below indicate concurrence, required in Section 5.3.5, that any mandatory comments made during the review were resolved satisfactorily, and that resolutions were reflected in the completed report.

Hongyen Wang

H. Wang

Waste Package Design, Thermal Analysis

$\frac{O / \mathrm{L} M \mathrm{Coy}}{\mathrm{J} / \mathrm{McCoy}}$

Performance Analysis and Engineered Materials

\section{A. Ptath}

D. Stahl

Waste Package Materials

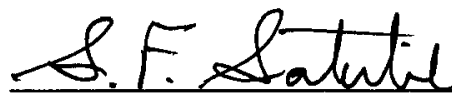

S. F. Saterlie

Systems Engineering

\section{W.S. Wallin}

W. E. Wallin

Product Checking Group

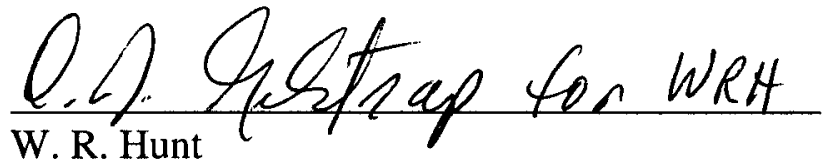

. R. Hunt

Quality Assurance $\frac{7 / 11 / 96}{\text { Date }}$

$7-11-96$

Date

$7 / 11 / 96$

Date

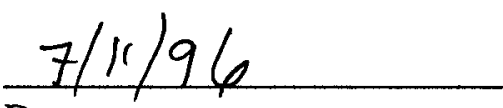

Date

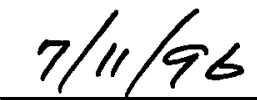

Date

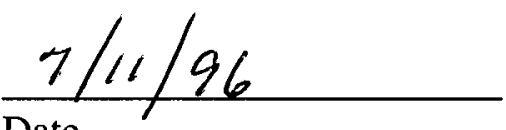

Date 


\section{EXECUTIVE SUMMARY}

This technical document, Spent Nuclear Fuel Effective Thermal Conductivity Report, is Waste Package Development fiscal year 1996 Deliverable No. ALT6226.

The objective of this report is to describe the development of effective thermal conductivities for pressurized water reactor (PWR) and boiling water reactor (BWR) spent nuclear fuel (SNF) assemblies as a methodology for performing future waste package thermal analyses. Finite element models of various SNF assembly types with fill environments of helium, vacuum, nitrogen, and argon have been developed and then used as the basis for the determination of effective thermal conductivities of assemblies with smeared (homogeneous) properties. Effective thermal conductivities are defined here using detailed models of intact SNF assemblies evaluated over a range of temperatures and heat loads. Effective thermal conductivities are an alternate methodology to the Wooton-Epstein correlation ${ }^{[5]}$ for the prediction of SNF peak cladding temperatures. Cladding temperatures determined using derived effective thermal conductivities are compared to temperatures using other cladding temperature prediction methods; and the finite element models and effective thermal conductivities are benchmarked against SNF storage cask tests. The discrete SNF assembly thermal models also provide the trending and thermal behavior of SNF assemblies with a dry fill gas including the effects of channels, water rods, oxidation thickness, and basket wall gradients. The effective thermal conductivities developed here provide a method for predicting (with a high level of confidence) a "best estimate" of peak cladding temperatures for SNF assemblies in a dry environment.

Over-prediction of SNF cladding temperatures due to excessive conservatism can constrain waste package design and limit the capacity of potential waste package design concepts. The analyses performed here indicate that the discrete SNF models are more accurate and realistic than other approaches for predicting SNF cladding temperatures. Further, the effective thermal conductivities, calculated using SNF model results, were found to be primarily a function of temperature, generally not a function of assembly heat load, and suitable for use in predicting best estimate temperatures of PWR and BWR SNF assemblies in fill environments of helium, vacuum, nitrogen, and argon (for at least the center of an SNF container where basket thermal gradients are low).

The effective thermal conductivities, both the basket wall temperature based values and the median temperature based values for use in finite element analyses (FEA), can be applied to SNF containers in a vertical or horizontal orientation. For fill environments of helium and vacuum, convection in a vertical container is minor or nonexistent and the effective thermal conductivity method would provide a best estimate prediction of peak cladding temperatures. For buoyant fill gases such as air, nitrogen, or argon, neglecting convection in a vertical container (a typical industry practice) would result in a small conservative bias when using the effective thermal conductivity method. Also, for horizontal container orientations, contact between the SNF assembly and the basket wall would tend to lower peak temperatures resulting in a best estimate or slightly conservative temperature predictions when using the effective thermal conductivity method. 


\section{Comparisons}

The discrete SNF assembly model results were compared to Wooton-Epstein correlation temperature predictions. For each helium fill gas case, the temperature drop across the assembly was roughly twice that predicted by the discrete PWR and BWR SNF models. For fill environments of vacuum, nitrogen, and argon, the Wooton-Epstein correlation was seen to be conservative at higher basket wall temperatures, but somewhat nonconservative at lower temperatures (however, at low temperatures, SNF cladding temperatures would not be near the design limits). The Wooton-Epstein results are not surprising, however, as the correlation was developed for PWR-sized assemblies in air.

Back check tests of the effective thermal conductivities for FEA were performed. The results showed cladding temperatures within $1.5^{\circ} \mathrm{C}$ of those estimated with the PWR and BWR discrete models (and less than $0.2^{\circ} \mathrm{C}$ in the heat load and temperature range of interest for disposal). The PWR and BWR effective thermal conductivities (for FEA) were also compared to numerical and experimental studies performed for the TN-24P $\mathrm{P}^{[23]}$ and REA $2023^{[20,21]}$ storage casks. For the single assembly comparisons to the TN-24P tests, the discrete PWR SNF model and effective thermal conductivities slightly over-predicted center assembly guide tube temperatures compared to thermocouple data reported. While no thermocouple data was available for peak cladding temperatures in that test, the discrete PWR SNF model predicted peak cladding temperatures nearly identical to those predicted by the COBRA-SFS numerical analysis conducted as part of the TN-24P test. For the half cask benchmark of the TN-24P, the inclusion of basket wall gradients around the homogeneous assemblies (with effective thermal conductivities) resulted in center assembly and basket temperatures that closely matched the experimental data. However, for locations where basket gradients were high (near the cask perimeter) the effective thermal conductivity method was seen to under-predict assembly temperatures. Finally, for the single assembly comparisons to the REA 2023 tests, the BWR effective thermal conductivities (for FEA) slightly over-predicted the cladding temperature of the BWR assembly center rod compared to thermocouple data reported. Also, the effective thermal conductivity method predicted comparable peak cladding temperatures to those predicted by the HYDRA and COBRA-SFS numerical analyses conducted as part of the REA 2023 tests.

For intact PWR and BWR assemblies, the conductivities derived from the discrete SNF models should provide a best estimate of SNF cladding temperatures. Effective thermal conductivities derived from the PWR SNF models compare quite well with effective thermal conductivities developed by General Atomics for the GA-4 cask $^{[33]}$ which were found to be just slightly more conservative. BWR effective thermal conductivities reported for the GA-9 cask, ${ }^{[34]}$ however, were found to be significantly nonconservative compared to the discrete SNF model results and the Wooton-Epstein correlation. Care should be taken, however, not to extrapolate the effective thermal conductivity results to alternate assembly designs (such as consolidated assemblies or assembly sizes not bounded here) or alternate fill gases for which calculations have not been completed at this time. 


\section{Recommended PWR Effective Thermal Conductivities}

Table S-1 summarizes the recommended bounding PWR effective thermal conductivity values to be used in conjunction with Equation 6.1-5 for analyses to predict the peak cladding temperature (based on a known basket wall temperature) without modeling the SNF assembly explicitly. Table S-2 summarizes the recommended bounding PWR effective thermal conductivity values to be used with finite element (or finite difference) methods which explicitly model the SNF assembly as a homogeneous heat source.

Table S-1. Average Effective Conductivities for PWR SNF (Basket Wall Based)

\begin{tabular}{|c||c|c|c|c||}
\hline $\begin{array}{c}\text { Basket Wall } \\
\text { Temperature }\end{array}$ & $\begin{array}{c}\text { Average } \mathrm{k}_{e} \\
(\mathrm{~W} / \mathrm{m} \cdot \mathrm{K}) \\
\text { in Helium }\end{array}$ & $\begin{array}{c}\text { Average } \mathrm{k}_{\mathrm{e}} \\
(\mathrm{W} / \mathrm{m} \cdot \mathrm{K}) \\
\text { in Vacuum }\end{array}$ & $\begin{array}{c}\text { Average } \mathrm{k}_{e} \\
(\mathrm{~W} / \mathrm{m} \cdot \mathrm{K}) \\
\text { in Nitrogen }\end{array}$ & $\begin{array}{c}\text { Average } \mathrm{k}_{\mathrm{e}} \\
(\mathrm{W} / \mathrm{m} \cdot \mathrm{K}) \\
\text { in Argon }\end{array}$ \\
\hline \hline $25^{\circ} \mathrm{C}$ & 0.412 & 0.136 & 0.185 & 0.170 \\
\hline $50^{\circ} \mathrm{C}$ & 0.451 & 0.157 & 0.210 & 0.195 \\
\hline $100^{\circ} \mathrm{C}$ & 0.540 & 0.209 & 0.272 & 0.253 \\
\hline $150^{\circ} \mathrm{C}$ & 0.643 & 0.277 & 0.347 & 0.326 \\
\hline $200^{\circ} \mathrm{C}$ & 0.762 & 0.363 & 0.440 & 0.417 \\
\hline $250^{\circ} \mathrm{C}$ & 0.898 & 0.469 & 0.551 & 0.525 \\
\hline $300^{\circ} \mathrm{C}$ & 1.053 & 0.596 & 0.682 & 0.654 \\
\hline $350^{\circ} \mathrm{C}$ & 1.224 & 0.743 & 0.832 & 0.804 \\
\hline $400^{\circ} \mathrm{C}$ & 1.414 & 0.914 & 1.005 & 0.976 \\
\hline
\end{tabular}

Table S-2. Effective Conductivities for PWR SNF (for FEA)

\begin{tabular}{|c|c|c|c|c|}
\hline $\begin{array}{c}\text { Assembly } \\
\text { Median } \\
\text { Temperature }\end{array}$ & $\begin{array}{c}\mathrm{K}_{\mathrm{e}} \text { for FEA } \\
\text { (W/m } \cdot \mathrm{K} \text { ) } \\
\text { in Helium }\end{array}$ & $\begin{array}{l}\mathrm{K}_{\mathrm{e}} \text { for FEA } \\
\text { (W/m } \cdot \mathrm{K} \text { ) } \\
\text { in Vacuum }\end{array}$ & $\begin{array}{c}\mathrm{K}_{\mathrm{e}} \text { for FEA } \\
\text { (W/m } \mathrm{W} \text { ) } \\
\text { in Nitrogen }\end{array}$ & $\begin{array}{c}\mathrm{K}_{\mathrm{e}} \text { for FEA } \\
(\mathrm{W} / \mathrm{m} \cdot \mathrm{K}) \\
\text { in Argon } \\
\end{array}$ \\
\hline $25^{\circ} \mathrm{C}$ & 0.384 & 0.086 & 0.144 & 0.127 \\
\hline $50^{\circ} \mathrm{C}$ & 0.423 & 0.107 & 0.170 & 0.152 \\
\hline $100^{\circ} \mathrm{C}$ & 0.512 & 0.163 & 0.232 & 0.212 \\
\hline $150^{\circ} \mathrm{C}$ & 0.616 & 0.234 & 0.310 & 0.288 \\
\hline $200^{\circ} \mathrm{C}$ & 0.736 & 0.324 & 0.406 & 0.380 \\
\hline $250^{\circ} \mathrm{C}$ & 0.874 & 0.432 & 0.519 & 0.491 \\
\hline $300^{\circ} \mathrm{C}$ & 1.028 & 0.561 & 0.651 & 0.622 \\
\hline $350^{\circ} \mathrm{C}$ & 1.201 & 0.711 & 0.804 & 0.774 \\
\hline $400^{\circ} \mathrm{C}$ & 1.392 & 0.884 & 0.978 & 0.948 \\
\hline
\end{tabular}




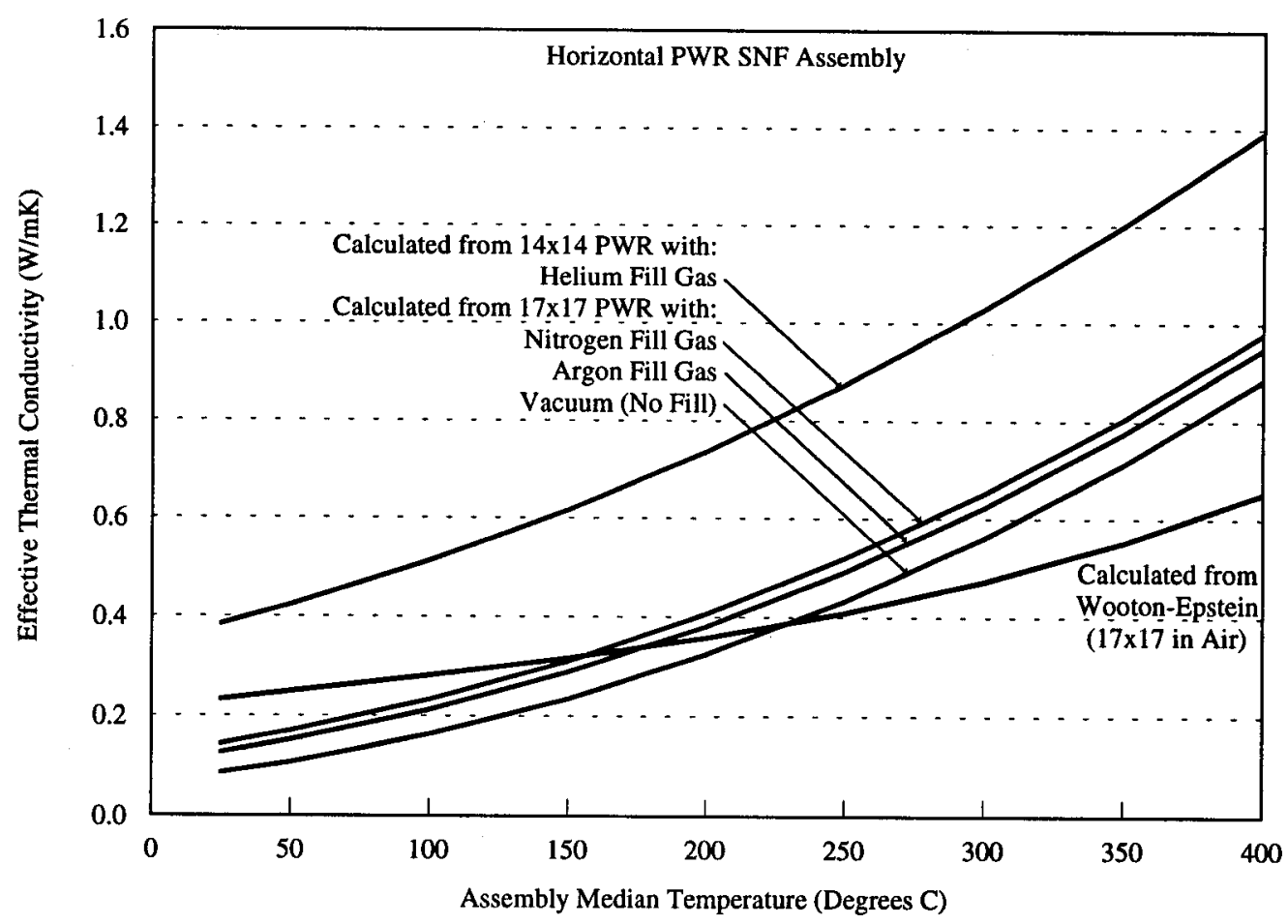

Figure S-1. Recommended PWR Effective Thermal Conductivities

Figure S-1 provides a comparison of the recommended PWR effective thermal conductivities for each fill environment option. For PWR assemblies, the $14 \times 14$ array bounded the other assemblies for helium, and the $17 \times 17$ array was bounding for the other fill environments. While the curves for vacuum, nitrogen, and argon are closely spaced, it is obvious that the use of helium as an SNF container fill gas can significantly reduce peak cladding temperatures. Further, the use of a correlation (such as Wooton-Epstein) developed for assemblies in air could limit the design of SNF containers by significantly over-predicting SNF cladding temperatures in an SNF container with helium fill gas.

\section{Recommended BWR Effective Thermal Conductivities}

For BWR assemblies, sufficient difference was observed between assemblies with the channels and assemblies with the channels removed, that separate effective thermal conductivities are provided for each. Tables S-3 and S-4 (with and without a channel) summarize the recommended bounding BWR effective thermal conductivity values to be used in conjunction with Equation 6.1-5 for analyses which predict peak cladding temperatures based on a known basket temperature without modeling the SNF assembly explicitly. 
Table S-3. Average Effective Conductivities for BWR SNF, with Channel

\begin{tabular}{|c||c|c|c|c||}
\hline $\begin{array}{c}\text { Basket Wall } \\
\text { Temperature }\end{array}$ & $\begin{array}{c}\text { Average } \mathrm{k}_{\mathrm{e}} \\
\text { (W/m/K) } \\
\text { in Helium }\end{array}$ & $\begin{array}{c}\text { Average } \mathrm{k}_{\mathrm{e}} \\
(\mathrm{W} / \mathrm{m} \cdot \mathrm{K}) \\
\text { in Vacuum }\end{array}$ & $\begin{array}{c}\text { Average } \mathrm{k}_{\mathrm{e}} \\
(\mathrm{W} / \mathrm{m} \cdot \mathrm{K}) \\
\text { in Nitrogen }\end{array}$ & $\begin{array}{c}\text { Average } \mathrm{k}_{\mathrm{e}} \\
(\mathrm{W} / \mathrm{m} \cdot \mathrm{K}) \\
\text { in Argon }\end{array}$ \\
\hline \hline $25^{\circ} \mathrm{C}$ & 0.303 & 0.094 & 0.128 & 0.118 \\
\hline $50^{\circ} \mathrm{C}$ & 0.332 & 0.110 & 0.147 & 0.136 \\
\hline $100^{\circ} \mathrm{C}$ & 0.396 & 0.150 & 0.192 & 0.180 \\
\hline $150^{\circ} \mathrm{C}$ & 0.470 & 0.202 & 0.250 & 0.235 \\
\hline $200^{\circ} \mathrm{C}$ & 0.556 & 0.278 & 0.320 & 0.304 \\
\hline $250^{\circ} \mathrm{C}$ & 0.655 & 0.348 & 0.405 & 0.386 \\
\hline $300^{\circ} \mathrm{C}$ & 0.768 & 0.446 & 0.505 & 0.485 \\
\hline $350^{\circ} \mathrm{C}$ & 0.892 & 0.560 & 0.621 & 0.602 \\
\hline $400^{\circ} \mathrm{C}$ & 1.032 & 0.692 & 0.755 & 0.735 \\
\hline
\end{tabular}

Table S-4. Average Effective Conductivities for BWR SNF, No Channel

\begin{tabular}{||c||c|c|c|c||}
\hline $\begin{array}{c}\text { Basket Wall } \\
\text { Temperature }\end{array}$ & $\begin{array}{c}\text { Average } \mathrm{k}_{\mathrm{c}} \\
(\mathrm{W} / \mathrm{m} \cdot \mathrm{K}) \\
\text { in Helium }\end{array}$ & $\begin{array}{c}\text { Average } \mathrm{k}_{\mathrm{e}} \\
(\mathrm{W} / \mathrm{m} \cdot \mathrm{K}) \\
\text { in Vacuum }\end{array}$ & $\begin{array}{c}\text { Average } \mathrm{k}_{\mathrm{c}} \\
(\mathrm{W} / \mathrm{m} \cdot \mathrm{K}) \\
\text { in Nitrogen }\end{array}$ & $\begin{array}{c}\text { Average } \mathrm{k}_{\mathrm{e}} \\
(\mathrm{W} / \mathrm{m} \cdot \mathrm{K}) \\
\text { in Argon }\end{array}$ \\
\hline \hline $25^{\circ} \mathrm{C}$ & 0.311 & 0.110 & 0.144 & 0.134 \\
\hline $50^{\circ} \mathrm{C}$ & 0.344 & 0.130 & 0.166 & 0.156 \\
\hline $100^{\circ} \mathrm{C}$ & 0.419 & 0.180 & 0.223 & 0.210 \\
\hline $150^{\circ} \mathrm{C}$ & 0.507 & 0.246 & 0.293 & 0.279 \\
\hline $200^{\circ} \mathrm{C}$ & 0.611 & 0.327 & 0.380 & 0.364 \\
\hline $250^{\circ} \mathrm{C}$ & 0.730 & 0.429 & 0.486 & 0.467 \\
\hline $300^{\circ} \mathrm{C}$ & 0.867 & 0.550 & 0.611 & 0.591 \\
\hline $350^{\circ} \mathrm{C}$ & 1.021 & 0.693 & 0.756 & 0.736 \\
\hline $400^{\circ} \mathrm{C}$ & 1.192 & 0.858 & 0.922 & 0.902 \\
\hline
\end{tabular}

Tables S-5 and S-6 (with and without a channel) summarize the recommended bounding BWR effective thermal conductivity values to be used with finite element (or finite difference) methods which explicitly model the SNF assembly as a homogeneous heat source. 
Spent Nuclear Fuel Effective Thermal Conductivity Report

DI: BBA000000-01717-5705-00010 REV 00

Page vi of xiv

Table S-5. Effective Conductivities for BWR SNF (for FEA), with Channel

\begin{tabular}{||c|c|c|c|c||}
\hline $\begin{array}{c}\text { Assembly } \\
\text { Median } \\
\text { Temperature }\end{array}$ & $\begin{array}{c}\mathrm{K}_{\mathrm{e}} \text { for FEA } \\
\text { in Helium }\end{array}$ & $\begin{array}{c}\mathrm{K}_{\mathrm{e}} \text { for FEA } \\
(\mathrm{W} / \mathrm{m} \cdot \mathrm{K}) \\
\text { in Vacuum }\end{array}$ & $\begin{array}{c}\mathrm{K}_{\mathrm{e}} \text { for FEA } \\
(\mathrm{W} / \mathrm{m} \cdot \mathrm{K}) \\
\text { in Nitrogen }\end{array}$ & $\begin{array}{c}\mathrm{K}_{\mathrm{c}} \text { for FEA } \\
(\mathrm{W} / \mathrm{m} \cdot \mathrm{K}) \\
\text { in Argon }\end{array}$ \\
\hline \hline $25^{\circ} \mathrm{C}$ & 0.290 & 0.067 & 0.105 & 0.094 \\
\hline $50^{\circ} \mathrm{C}$ & 0.317 & 0.081 & 0.122 & 0.110 \\
\hline $100^{\circ} \mathrm{C}$ & 0.379 & 0.121 & 0.167 & 0.153 \\
\hline $150^{\circ} \mathrm{C}$ & 0.455 & 0.175 & 0.226 & 0.210 \\
\hline $200^{\circ} \mathrm{C}$ & 0.542 & 0.244 & 0.299 & 0.282 \\
\hline $250^{\circ} \mathrm{C}$ & 0.643 & 0.328 & 0.387 & 0.369 \\
\hline $300^{\circ} \mathrm{C}$ & 0.755 & 0.427 & 0.489 & 0.470 \\
\hline $350^{\circ} \mathrm{C}$ & 0.881 & 0.542 & 0.605 & 0.585 \\
\hline $400^{\circ} \mathrm{C}$ & 1.019 & 0.673 & 0.736 & 0.715 \\
\hline
\end{tabular}

Table S-6. Effective Conductivities for BWR SNF (for FEA), No Channel

\begin{tabular}{||c||c|c|c|c||}
\hline $\begin{array}{c}\text { Assembly } \\
\text { Median } \\
\text { Temperature }\end{array}$ & $\begin{array}{c}\mathrm{K}_{\mathrm{e}} \text { for FEA } \\
\text { in Helium }\end{array}$ & $\begin{array}{c}\mathrm{K}_{\mathrm{e}} \text { for FEA } \\
(\mathrm{W} / \mathrm{m} \cdot \mathrm{K}) \\
\text { in Vacuum }\end{array}$ & $\begin{array}{c}\mathrm{K}_{\mathrm{e}} \text { for FEA } \\
(\mathrm{W} / \mathrm{m} \cdot \mathrm{K}) \\
\text { in Nitrogen }\end{array}$ & $\begin{array}{c}\mathrm{K}_{\mathrm{e}} \text { for FEA } \\
\text { (W/m· }) \\
\text { in Argon }\end{array}$ \\
\hline \hline $25^{\circ} \mathrm{C}$ & 0.296 & 0.082 & 0.120 & 0.109 \\
\hline $50^{\circ} \mathrm{C}$ & 0.327 & 0.100 & 0.141 & 0.129 \\
\hline $100^{\circ} \mathrm{C}$ & 0.400 & 0.149 & 0.195 & 0.181 \\
\hline $150^{\circ} \mathrm{C}$ & 0.489 & 0.217 & 0.268 & 0.252 \\
\hline $200^{\circ} \mathrm{C}$ & 0.595 & 0.303 & 0.359 & 0.342 \\
\hline $250^{\circ} \mathrm{C}$ & 0.717 & 0.408 & 0.468 & 0.449 \\
\hline $300^{\circ} \mathrm{C}$ & 0.855 & 0.533 & 0.595 & 0.575 \\
\hline $350^{\circ} \mathrm{C}$ & 1.009 & 0.676 & 0.740 & 0.719 \\
\hline $400^{\circ} \mathrm{C}$ & 1.178 & 0.838 & 0.903 & 0.882 \\
\hline
\end{tabular}

Figures S-2 and S-3 provide comparisons of the recommended BWR effective thermal conductivities for each fill environment option with and without an $80 \mathrm{mil}$ channel, respectively. For BWR assemblies, the 9x9 array bounded the other assemblies for all of the fill environments. Similar trending to the PWR SNF is observed for both the channel and no channel cases. Again, the fill environments of vacuum, nitrogen, and argon are closely grouped with the results of the WootonEpstein correlation. Helium, however, provides a much higher effective thermal conductivity, and therefore would provide significantly lower temperatures in SNF containers that are filled with helium. 


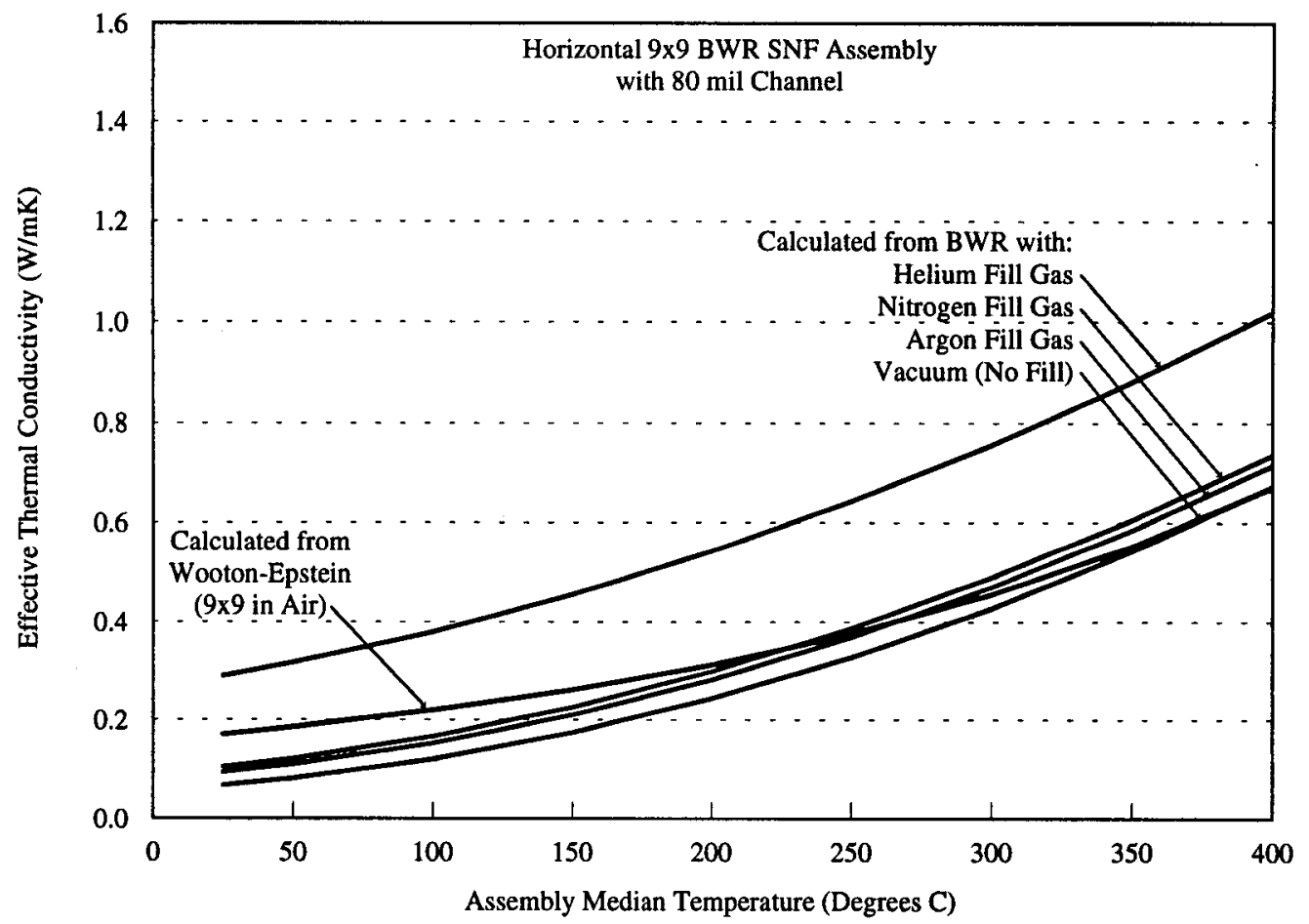

Figure S-2. Recommended BWR (w/ Channel) Effective Thermal Conductivities

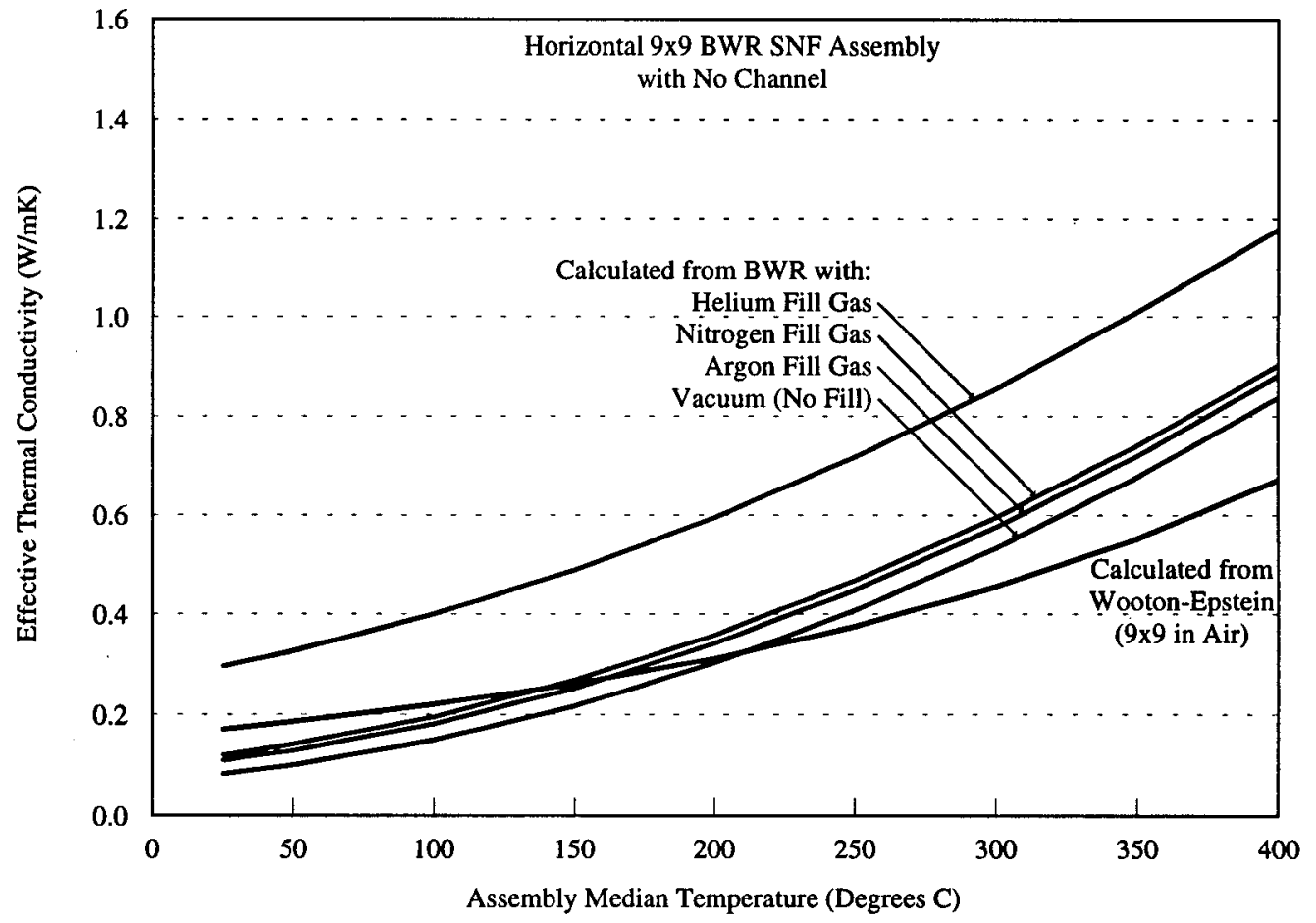

Figure S-3. Recommended BWR (No Channel) Effective Thermal Conductivities 
BWR assemblies without channels can be evaluated using the effective thermal conductivities for assemblies with channels, however, this approach may be overly conservative for some evaluations. Therefore, the conductivities for BWR assemblies both with and without channels are reported here. However, if a "generic" BWR assembly is the target of a thermal evaluation, it is recommended that the effective thermal conductivities for channeled BWR assemblies be used to be conservative. Also, while the different PWR and BWR assembly designs resulted in minor differences that can be bounded by one assembly array for each fill environment, results for different fill environments varied significantly. Therefore, the appropriate effective thermal conductivity should be chosen for use based on the expected fill gas for thermal evaluations of SNF containers.

\section{Evaluation Guidelines}

The following recommendations should be followed when using the effective thermal conductivity data with finite element codes (see Figure 1.5-1). It should be noted that only even mesh grids (14x14 suggested for PWR assemblies and 10x10 suggested for BWR assemblies) should be used when using the effective thermal conductivity results with finite element codes. This mesh spacing places a local node at the center of the SNF assembly and will calculate a temperature at this location directly. If an odd spacing is used, the mesh will interpolate this point consistent with the finite element method. The PWR and BWR basket cell widths assumed for these analyses were 0.2235 meters ( 8.8 inches) and 0.1524 meters ( 6.0 inches), respectively. However, the size of the basket opening or the assembly should not affect the calculation or invalidate the effective thermal conductivity. The derivation of the effective thermal conductivity does not depend on the basket width; it is only an average thermal conductivity for the region being modeled. Also, increasing the gap between the SNF assembly and the basket wall should have a minimal effect since the heat transfer is predominately by radiation; however, this can be affected by fill gas conductivity. Generally, for reasonable basket designs, the gap size will not have a significant impact on the use of the effective thermal conductivity. When calculating the heat load to apply to the SNF region, use the cross sectional area or volume of the modeled region (the SNF basket opening), not the area or volume of the SNF assembly. Using the SNF assembly area or volume will result in a larger heat load per volume for the modeled region and the calculation will over-predict the peak SNF cladding temperatures.

Temperature-dependent SNF effective thermal conductivities provide a simple method for calculating best estimate SNF peak cladding temperatures. The design analyses which contain the calculations performed in support of this technical document are for preliminary design and contain unqualified/uncomfirmed data and assumptions. These input data and assumptions will require further confirmation as the waste package design proceeds. However, the conductivities reported here were developed in a reproducible calculation with an industry standard code, with limited benchmarks to work previously performed within the Civilian Radioactive Waste Management System (CRWMS), such that some confidence can be given to these reported results. 


\section{Table of Contents}

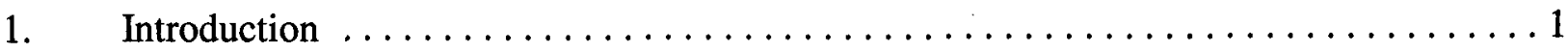

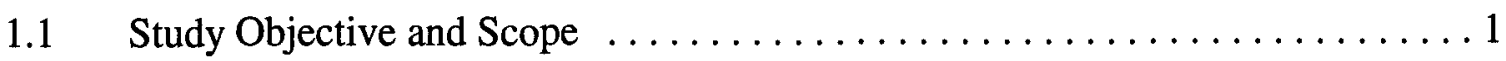

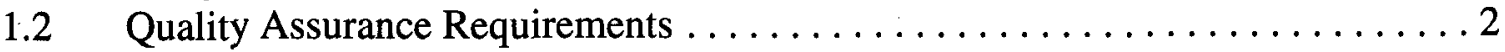

1.3 Design Requirements and Criteria $\ldots \ldots \ldots \ldots \ldots \ldots \ldots \ldots \ldots \ldots \ldots$

1.3.1 Waste Package Development Technical Document ............ 4

1.3.2 Engineered Barrier Design Requirements Document (EB-DRD) . . . . . 4

1.3.3 ASME Boiler and Pressure Vessel Code . . . . . . . . . . . . . . 5

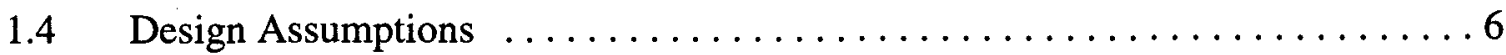

1.5 Background and Technical Approach $\ldots \ldots \ldots \ldots \ldots \ldots \ldots \ldots \ldots \ldots \ldots$

2. Methods of Predicting Peak Cladding Temperatures $\ldots \ldots \ldots \ldots \ldots \ldots \ldots \ldots$

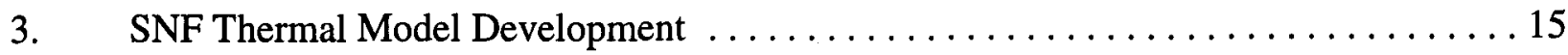

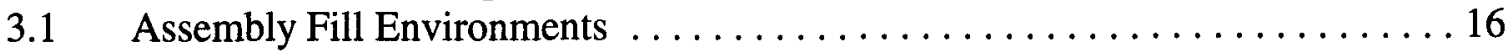

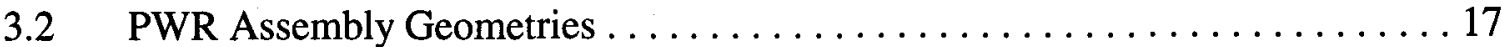

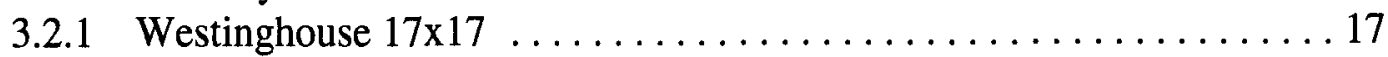

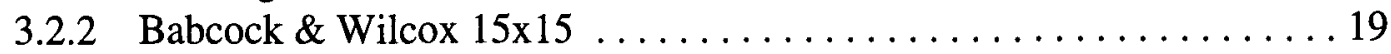

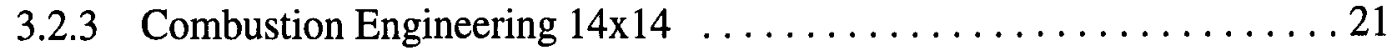

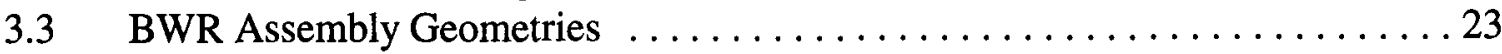

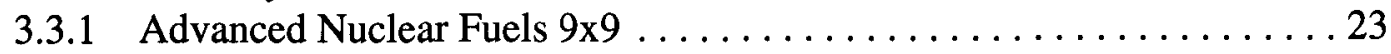

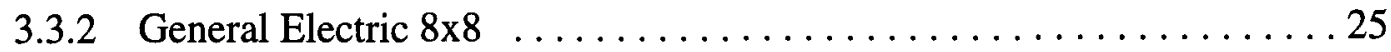

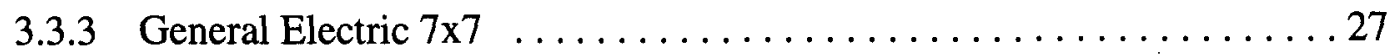

3.3.4 Disposal of BWR Assemblies without Channels ............. 28

3.3.5 BWR Designs with Water Rods ...................... 29

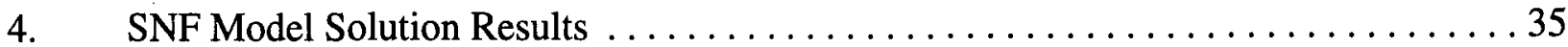

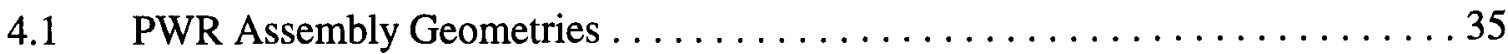

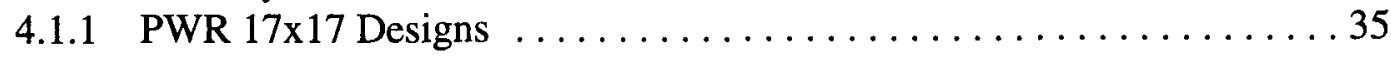

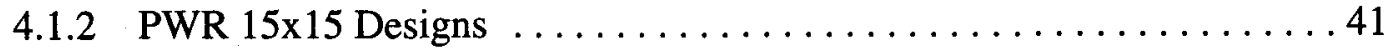

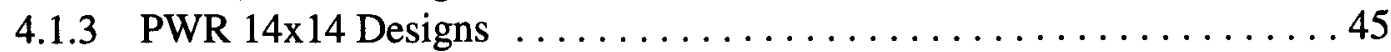

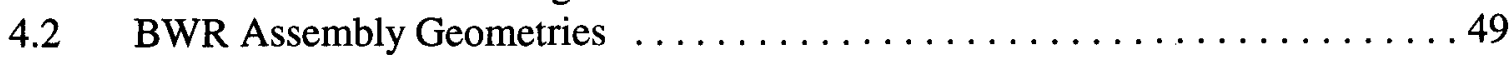

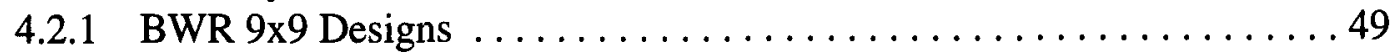

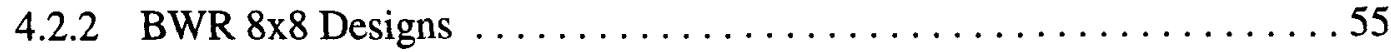

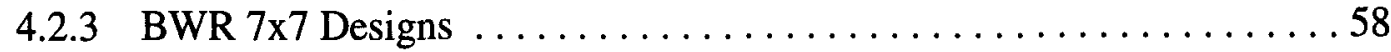

4.2.4 Disposal of BWR Assemblies without Channels . . . . . . . . . . 61

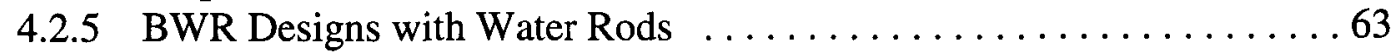

4.2.6 Cladding Oxidation Layer Effects $\ldots \ldots \ldots \ldots \ldots \ldots \ldots \ldots \ldots \ldots$

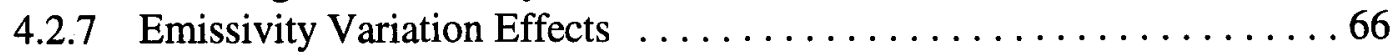

4.2.8 Basket Wall Temperature Gradient Effects . . . . . . . . . . . 67 


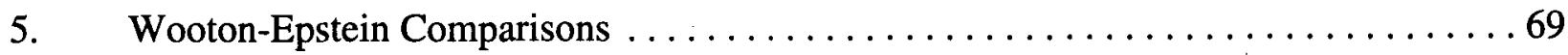

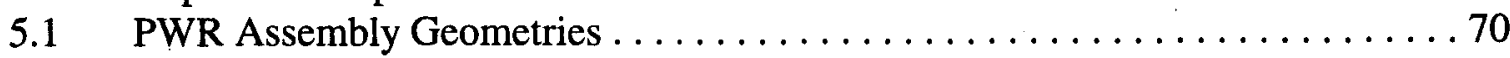

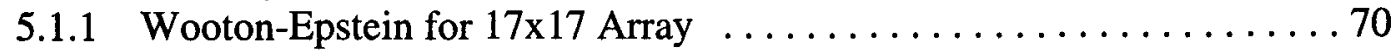

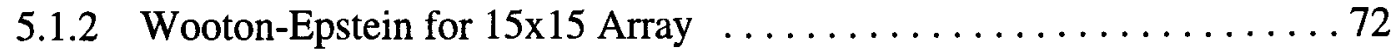

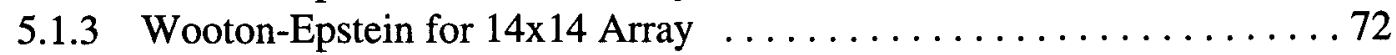

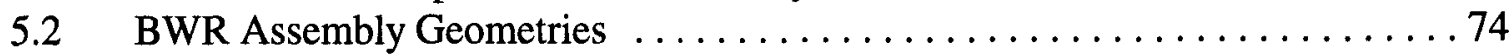

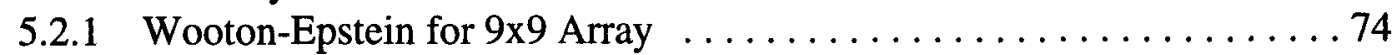

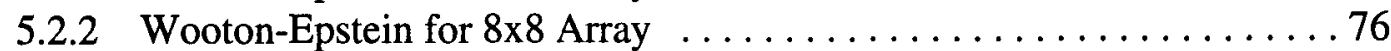

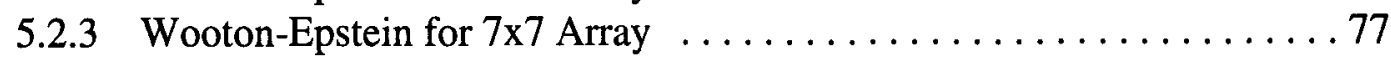

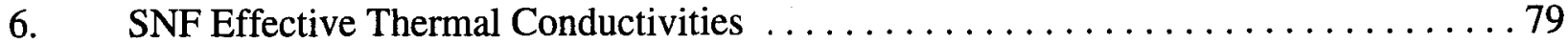

6.1 Effective Thermal Conductivity Development $\ldots \ldots \ldots \ldots \ldots \ldots \ldots$

6.2 PWR Assembly Geometries . . . . . . . . . . . . . . . . . . 82

6.2.1 Effective Conductivity for Known Basket Wall Temperatures . . . . . . 82

6.2 .2 Effective Conductivity for Finite Element Analysis . . . . . . . . . 88

6.3 BWR Assembly Geometries . . . . . . . . . . . . . . . . . 96

6.3.1 Effective Conductivity for Known Basket Wall Temperatures . . . . . . 96

6.3.2 Effective Conductivity for Finite Element Analysis . . . . . . . . . . 102

6.4 Effective Thermal Conductivity Comparisons $\ldots \ldots \ldots \ldots \ldots \ldots \ldots \ldots 11$

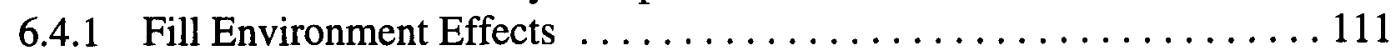

6.4 .2 Assembly Designs $\ldots \ldots \ldots \ldots \ldots \ldots \ldots \ldots \ldots \ldots \ldots \ldots \ldots$

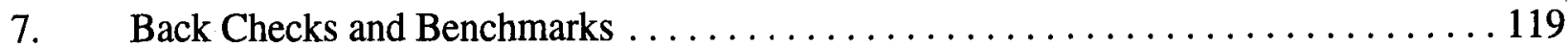

7.1 Back Check of Effective Thermal Conductivity $\ldots \ldots \ldots \ldots \ldots \ldots \ldots \ldots$

7.1.1 PWR Assembly Geometries . . . . . . . . . . . . . . . . . 119

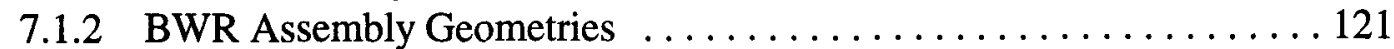

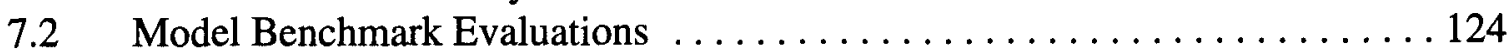

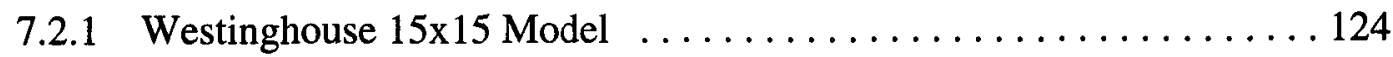

7.2.2 Comparisons to TN-24P Storage Cask Tests . . . . . . . . . . . 125

7.2.3 Comparisons to REA 2023 Storage Cask Tests . . . . . . . . . . . . . 132

7.3 Half Cask Benchmark of Effective Thermal Conductivity . . . . . . . . . 136

8. Conclusions and Recommendations $\ldots \ldots \ldots \ldots \ldots \ldots \ldots \ldots \ldots \ldots \ldots \ldots$

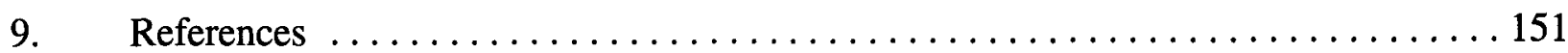




\section{$\underline{\text { List of Figures }}$}

Figure S-1. Recommended PWR Effective Thermal Conductivities $\ldots \ldots \ldots \ldots \ldots \ldots$ iv

Figure S-2. Recommended BWR (w/ Channel) Effective Thermal Conductivities ........ vii

Figure S-3. Recommended BWR (No Channel) Effective Thermal Conductivities ....... vii Figure 1.5-1. Waste Package Thermal Model Using SNF Effective Conductivity . ........ 11 Figure 3.2-1. Finite Element Model, Westinghouse 17x17 PWR Assembly ............ 18

Figure 3.2-2. Thermal Radiation Surfaces, Westinghouse 17x17 PWR Assembly . . . . . . . 19

Figure 3.2-3. Finite Element Model, B\&W 15x15 PWR Assembly ................ 20

Figure 3.2-4. Finite Element Model, CE 14x14 PWR Assembly .................. 21

Figure 3.3-1. Finite Element Model, ANF 9x9 BWR Assembly $\ldots \ldots \ldots \ldots \ldots \ldots \ldots . \ldots 24$

Figure 3.3-2. Thermal Radiation Surfaces, GE 9x9 BWR Assembly ............... 25

Figure 3.3-3. Finite Element Model, GE 8x8 BWR Assembly $\ldots \ldots \ldots \ldots \ldots \ldots \ldots$

Figure 3.3-4. Finite Element Model, GE 7x7 BWR Assembly .................. 27

Figure 3.3-5. Finite Element Model, ANF 9x9 BWR Assembly with Water Channel . . . . . . 30

Figure 3.3-6. Finite Element Model, GE 8x8 BWR Assembly with Water Rod .......... 31

Figure 4.1-1. Temperatures in 17x17 PWR SNF Assembly with Helium Fill Gas . . . . . . . 37

Figure 4.2-1. Temperatures in 9x9 BWR SNF Assembly with Helium Fill Gas . . . . . . . 51

Figure 6.2-1. Average PWR Effective Thermal Conductivities for Helium . . . . . . . . . . 84

Figure 6.2-2. Average PWR Effective Thermal Conductivities for Vacuum . . . . . . . . . 85

Figure 6.2-3. Average PWR Effective Thermal Conductivities for Nitrogen $\ldots \ldots \ldots \ldots . . .66$

Figure 6.2-4. Average PWR Effective Thermal Conductivities for Argon . . . . . . . . . 87

Figure 6.2-5. PWR Effective Thermal Conductivities for FEA with Helium . . . . . . . . . 90

Figure 6.2-6. PWR Effective Thermal Conductivities for FEA with Vacuum . . . . . . . . . 91

Figure 6.2-7. PWR Effective Thermal Conductivities for FEA with Nitrogen . . . . . . . 92

Figure 6.2-8. PWR Effective Thermal Conductivities for FEA with Argon $\ldots \ldots \ldots \ldots \ldots 93$

Figure 6.3-1. Average BWR Effective Thermal Conductivities for Helium . . . . . . . . . . 97

Figure 6.3-2. Average BWR Effective Thermal Conductivities for Vacuum . . . . . . . . . . . 98

Figure 6.3-3. Average BWR Effective Thermal Conductivities for Nitrogen . . . . . . . . . 99

Figure 6.3-4. Average BWR Effective Thermal Conductivities for Argon . . . . . . . . . 100

Figure 6.3-5. BWR Effective Thermal Conductivities for FEA with Helium . . . . . . . . . 104

Figure 6.3-6. BWR Effective Thermal Conductivities for FEA with Vacuum . . . . . . . . 105

Figure 6.3-7. BWR Effective Thermal Conductivities for FEA with Nitrogen $\ldots \ldots \ldots \ldots 106$

Figure 6.3-8. BWR Effective Thermal Conductivities for FEA with Argon . . . . . . . . . 107

Figure 6.4-1. Fill Gas Comparison for PWR Effective Thermal Conductivities . . . . . . 112

Figure 6.4-2. Fill Gas Comparison for BWR (w/ Channel) Effective Conductivities . . . . . 113

Figure 6.4-3. Fill Gas Comparison for BWR (No Channel) Effective Conductivities . . . . . . 114

Figure 6.4-4. PWR \& BWR Effective Thermal Conductivity Comparison for Helium . . . . . 115

Figure 6.4-5. PWR \& BWR Effective Thermal Conductivities Comparison for Nitrogen . . . 116

Figure 7.2-1. Basket and Assembly Thermocouple Locations for the TN-24P Test . . . . . . 126

Figure 7.2-2. TN-24P Benchmark for Assembly D1, Horizontal with Helium Fill Gas . . . . . 129

Figure 7.3-1. TN-24P Half Cask Benchmark, Horizontal with Helium Fill Gas . . . . . . . . . 139 
Spent Nuclear Fuel Effective Thermal Conductivity Report

DI: BBA000000-01717-5705-00010 REV 00

Page xii of xiv

List of Tables

Table S-1. Average Effective Conductivities for PWR SNF (Basket Wall Based) . . . . . . iii Table S-2. Effective Conductivities for PWR SNF (for FEA) $\ldots \ldots \ldots \ldots \ldots \ldots \ldots$ iii Table S-3. Average Effective Conductivities for BWR SNF, with Channel $\ldots \ldots \ldots \ldots \ldots$ v Table S-4. Average Effective Conductivities for BWR SNF, No Channel $\ldots \ldots \ldots \ldots \ldots$ v Table S-5. Effective Conductivities for BWR SNF (for FEA), with Channel $\ldots \ldots \ldots \ldots \ldots$ vi Table S-6. Effective Conductivities for BWR SNF (for FEA), No Channel . . . . . . . . . vi

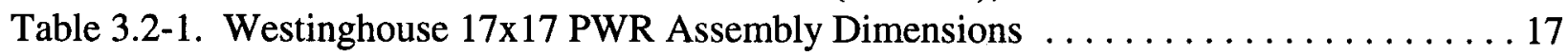
Table 3.2-2. B\&W 15x15 PWR Assembly Dimensions ..................... 20 Table 3.2-3. CE 14x14 PWR Assembly Dimensions ........................ 22 Table 3.3-1. ANF-JP 9x9 BWR Assembly Dimensions .................... 23 Table 3.3-2. GE-5 8x8 BWR Assembly Dimensions ...................... 26

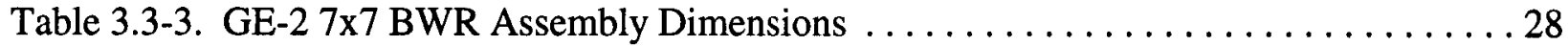
Table 3.3-4. ANF 9x9 BWR Assembly with Water Channel Dimensions ............. 32 Table 3.3-5, GE-9 8x8 BWR Assembly with Water Rod Dimensions ............... 33 Table 3.3-6. ANF 7x7 BWR Assembly with Water Rod Dimensions ................ 33 Table 4.1-1. Peak Cladding Temperatures, $17 \times 17$ PWR Assembly with Helium Fill Gas . ...36 Table 4.1-2. Cladding-to-Basket Delta T, 17x17 PWR Assembly with Helium Fill Gas . . . . 36 Table 4.1-3. Peak Temperature Difference (Vacuum vs. Helium), 17x17 PWR Assembly . . . 40 Table 4.1-4. Peak Temperature Difference (Nitrogen vs. Helium), 17x17 PWR Assembly . . .40 Table 4.1-5. Peak Temperature Difference (Argon vs. Helium), 17x17 PWR Assembly . ... 41 Table 4.1-6. Peak Cladding Temperatures, 15x15 PWR Assembly with Helium Fill Gas . . . 42 Table 4.1-7. Cladding-to-Basket Delta T, 15x15 PWR Assembly with Helium Fill Gas . . . . 42 Table 4.1-8. Peak Temperature Difference (Vacuum vs. Helium), 15x15 PWR Assembly . . . . 43 Table 4.1-9. Peak Temperature Difference (Nitrogen vs. Helium), 15x15 PWR Assembly . .. 43 Table 4.1-10. Peak Temperature Difference (Argon vs. Helium), 15x15 PWR Assembly . . . 44 Table 4.1-11. Peak Cladding Temperatures, 14x14 PWR Assembly with Helium Fill Gas . . . 45 Table 4.1-12. Cladding-to-Basket Delta T, 14x14 PWR Assembly with Helium Fill Gas . ... 46 Table 4.1-13. Peak Temperature Difference (Vacuum vs. Helium), 14x14 PWR Assembly . . 46 Table 4.1-14. Peak Temperature Difference (Nitrogen vs. Helium), 14x14 PWR Assembly .. 47 Table 4.1-15. Peak Temperature Difference (Argon vs. Helium), 14x14 PWR Assembly . . . 47 Table 4.2-1. Peak Cladding Temperatures, 9x9 BWR Assembly with Helium Fill Gas . . . . . 50 Table 4.2-2. Cladding-to-Basket Delta T, 9x9 BWR Assembly with Helium Fill Gas . . . . . . 50 Table 4.2-3. Peak Temperature Difference (Vacuum vs. Helium), 9x9 BWR Assembly . ... 54 Table 4.2-4. Peak Temperature Difference (Nitrogen vs. Helium), 9x9 BWR Assembly . . .. 54 Table 4.2-5. Peak Temperature Difference (Argon vs. Helium), 9x9 BWR Assembly ...... 55 Table 4.2-6. Peak Cladding Temperatures, 8x8 BWR Assembly with Helium Fill Gas ......56 Table 4.2-7. Cladding-to-Basket Delta T, 8x8 BWR Assembly with Helium Fill Gas . . . . . 56 Table 4.2-8. Peak Temperature Difference (Vacuum vs. Helium), 8x8 BWR Assembly . . .. 57 Table 4.2-9. Peak Temperature Difference (Nitrogen vs. Helium), 8x8 BWR Assembly . . . 57 Table 4.2-10. Peak Temperature Difference (Argon vs. Helium), 8x8 BWR Assembly . . . . . 58 Table 4.2-11. Peak Cladding Temperatures, $7 \times 7$ BWR Assembly with Helium Fill Gas . . . . 59 Table 4.2-12. Cladding-to-Basket Delta T, $7 \times 7$ BWR Assembly with Helium Fill Gas . . ... 59 
Table 4.2-13. Peak Temperature Difference (Vacuum vs. Helium), 7x7 BWR Assembly . . .66 60 Table 4.2-14. Peak Temperature Difference (Nitrogen vs. Helium), 7x7 BWR Assembly . . . 60 Table 4.2-15. Peak Temperature Difference (Argon vs. Helium), 7x7 BWR Assembly . . ...61 61 Table 4.2-16. Peak Temperature Difference ( 80 mil vs. No Channel), 9x9 BWR in Helium . . 62 Table 4.2-17. Peak Temperature Difference ( 80 mil vs. No Channel), 9x9 BWR in Vacuum . 63 Table 4.2-18. Oxide Layer Temperature Drop Versus Oxide Layer Thickness . . . . . . . . 66 Table 5.1-1. Peak Cladding Temperatures, Wooton-Epstein Correlation (17x17) . . . . . . 70 Table 5.1-2. Cladding-to-Basket Delta T, Wooton-Epstein Correlation (17x17) . . . . . . . 71 Table 5.1-3. Peak Temperature Difference (Wooton-Epstein vs. 17x17 PWR in Nitrogen) . . 71 Table 5.1-4. Peak Temperature Difference (Wooton-Epstein $17 \times 17$ vs. $15 \times 15$ ) . . . . . . . 72 Table 5.1-5. Peak Temperature Difference (Wooton-Epstein $17 \times 17$ vs. $14 \times 14$ ) . . . . . . . 73 Table 5.2-1. Peak Cladding Temperatures, Wooton-Epstein Correlation $(9 \times 9) \ldots \ldots \ldots \ldots .74$ Table 5.2-2. Cladding-to-Basket Delta $\mathrm{T}$, Wooton-Epstein Correlation $(9 \times 9) \ldots \ldots \ldots \ldots 75$ Table 5.2-3. Peak Temperature Difference (Wooton-Epstein vs. 9x9 BWR in Nitrogen) . . . . 76 Table 5.2-4. Peak Temperature Difference (Wooton-Epstein 9x9 vs. 8x8) . . . . . . . . . 76 Table 5.2-5. Peak Temperature Difference (Wooton-Epstein 9x9 vs. 7x7) . ........... 77 Table 6.2-1. Average Effective Conductivities for PWR SNF (Basket Wall Based) . . . . . . 88 Table 6.2-2. Effective Conductivities for PWR SNF (for FEA) . . . . . . . . . . . . . 94 Table 6.3-1. Average Effective Conductivities for BWR SNF, with Channel . . . . . . . . 101 Table 6.3-2. Average Effective Conductivities for BWR SNF, No Channel ........... 102 Table 6.3-3. Effective Conductivities for BWR SNF (for FEA), with Channel . . . . . . 108 Table 6.3-4. Effective Conductivities for BWR SNF (for FEA), No Channel . . . . . . . . . . 109 Table 7.1-1. Peak Temperature Difference (17x17 PWR in Vacuum vs. Hom. Model) . . . . 120 Table 7.1-2. Maximum Temperature Difference for Homogeneous PWR Back Check . . . . 120 Table 7.1-3. Peak Temperature Difference (9x9 BWR in Vacuum vs. Hom. Model) . . . . . 122 Table 7.1-4. Maximum Temperature Difference for Homogeneous BWR Back Check . . . . 122 Table 7.2-1. Westinghouse 15x15 PWR Assembly Dimensions .................. 124 Table 7.2-2. TN-24P Basket Thermocouple Temperatures at Axial Mid-Length . . . . . . 125

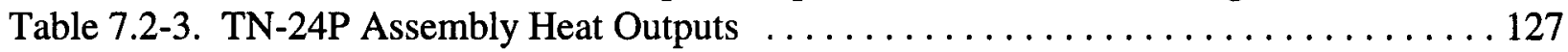
Table 7.2-4. TN-24P Benchmark Temperature Comparisons $\ldots \ldots \ldots \ldots \ldots \ldots \ldots \ldots . \ldots . \ldots . \ldots . \ldots 128$ Table 7.2-5. REA 2023 Thermocouple Temperatures at Axial Mid-Length ............ 132 Table 7.2-6. REA 2023 Assembly Heat Outputs . . . . . . . . . . . . . . . 133 Table 7.3-1. TN-24P Surface Thermocouple Temperatures at Axial Mid-Length . . . . . . . 136

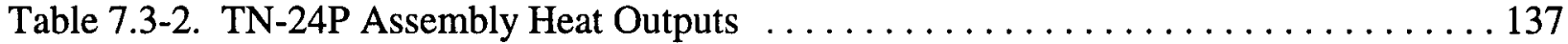
Table 7.3-3. TN-24P Half Cask Temperature Benchmark Comparisons ............... 138 Table 8.0-1. Average Effective Conductivities for PWR SNF (Basket Wall Based) . . . . . . 145 Table 8.0-2. Effective Conductivities for PWR SNF (for FEA) . . . . . . . . . . . . 146 Table 8.0-3. Average Effective Conductivities for BWR SNF, with Channel . . . . . . . . . . 146 Table 8.0-4. Average Effective Conductivities for BWR SNF, No Channel . . . . . . . . . 147 Table 8.0-5. Effective Conductivities for BWR SNF (for FEA), with Channel . . . . . . . . 147 Table 8.0-6. Effective Conductivities for BWR SNF (for FEA), No Channel . . . . . . . 148 


\section{$\underline{\text { List of Abbreviations }}$}

$\begin{array}{ll}\text { ANF } & \text { Advanced Nuclear Fuels } \\ \text { ASME } & \text { American Society of Mechanical Engineers } \\ \text { BWR } & \text { Boiling Water Reactor } \\ \text { B\&W } & \text { Babcock and Wilcox } \\ \text { CDA } & \text { Controlled Design Assumptions (document) } \\ \text { CE } & \text { Combustion Engineering } \\ \text { CFR } & \text { Code of Federal Regulations } \\ \text { CRWMS } & \text { Civilian Radioactive Waste Management System } \\ \text { CSCI } & \text { Computer Software Configuration Item } \\ \text { DI } & \text { Document Identifier } \\ \text { DOE } & \text { Department of Energy } \\ \text { EB-DRD } & \text { Engineered Barrier Design Requirements Document } \\ \text { EBS } & \text { Engineered Barrier System } \\ \text { FEA } & \text { Finite Element Analysis } \\ \text { FEM } & \text { Finite Element Model } \\ \text { GE } & \text { General Electric } \\ \text { GE-MO } & \text { General Electric Morris Operation } \\ \text { GWd } & \text { Gigawatt Day } \\ \text { INEL } & \text { Idaho National Engineering Laboratory } \\ \text { LLNL } & \text { Lawrence Livermore National Laboratory } \\ \text { MGDS } & \text { Mined Geologic Disposal System } \\ \text { MPC } & \text { Multi-Purpose Canister } \\ \text { MTU } & \text { Metric Tons of Uranium } \\ \text { M\&O } & \text { Management and Operating Contractor } \\ \text { NLP } & \text { Nevada Line Procedure } \\ \text { NRC } & \text { Nuclear Regulatory Commission } \\ \text { PNL } & \text { Pacific Northwest National Laboratory } \\ \text { PWR } & \text { Pressurized Water Reactor } \\ \text { QA } & \text { Quality Assurance } \\ \text { QAP } & \text { Quality Administrative Procedure } \\ \text { QARD } & \text { Quality Assurance Requirements and Description (document) } \\ \text { SNF } & \text { Spent Nuclear Fuel } \\ \text { SNL } & \text { Sandia National Laboratories } \\ \text { TBD/V/R } & \text { To-Be-Determined/To-Be-Verified/To-Be-Resolved } \\ \text { TDPP } & \text { Technical Document Preparation Plan } \\ \text { 3-D } & \text { Three Dimensional } \\ \text { 2-D } & \text { Two Dimensional } \\ \text { UCF } & \text { Uncanistered Fuel } \\ \text { WA } & \text { Waste Acceptance } \\ \text { WHB } & \text { Waste Handling Building } \\ \text { WP } & \text { Waste Package } \\ \text { WPDD } & \text { Waste Package Development Department } \\ \text { YMP } & \text { Yucca Mountain Site Characterization Project } \\ & \end{array}$




\section{Introduction}

This technical document, Spent Nuclear Fuel Effective Thermal Conductivity Report, is Waste Package Development fiscal year 1996 Deliverable No. ALT6226. The report establishes effective thermal conductivities of spent nuclear fuel (SNF) assemblies for use in thermal evaluations supporting waste package design. The thermal evaluation analyses are required as described on page 23 of the Waste Package Development Technical Document. ${ }^{[17]}$

\subsection{Study Objective and Scope}

The objective of this document is to describe the development of effective thermal conductivities for SNF assemblies as a methodology for performing future waste package thermal analyses. Finite element models of various SNF assembly types with fill environments of helium, vacuum, nitrogen, and argon have been developed and then used as the basis for the determination of effective thermal conductivities of assemblies with smeared (homogeneous) properties. Effective thermal conductivities are an alternative methodology to the previously developed "Wooton-Epstein"[5] correlation for the prediction of SNF cladding temperatures. Cladding temperatures determined using derived effective thermal conductivities are compared to temperatures using other cladding temperature prediction methods, and the finite element models (discrete and homogeneous) are benchmarked against SNF storage cask tests. The effective thermal conductivities developed here provide a method for predicting (with a high level of confidence) a "best estimate" of peak cladding temperatures for SNF assemblies in a dry environment.

While these evaluations were originally developed for the thermal analysis of conceptual waste package (WP) designs emplaced in the potential repository at Yucca Mountain, the methodology may also apply to the thermal analysis of dry SNF in any container. Primarily, the effective thermal conductivities presented will be used by the Mined Geological Disposal System (MGDS) for the thermal analyses of waste package designs. Effective thermal conductivities developed for different SNF types and fill environments are compared to each other and to other cladding temperature prediction methodologies. Pressurized water reactor (PWR) assembly geometries of $17 \times 17,15 \times 15$, and $14 \times 14$ and boiling water reactor (BWR) assembly geometries of $9 \times 9,8 \times 8$, and $7 \times 7$ are considered. The effect of channels and water rods are considered for BWR assemblies. For each geometry, a finite element model was developed and evaluated over a range of heat loads and SNF basket temperatures with fill environments of helium, vacuum, nitrogen, and argon. The discrete SNF models are used to develop a basis for determining an effective thermal conductivity for an assembly with smeared/homogeneous properties and also to investigate the thermal behavior of a spent fuel assembly. 


\subsection{Quality Assurance Requirements}

The Quality Assurance (QA) program applies to the development of this technical document. The activities described can impact the proper functioning of the MGDS waste package; the waste package has been identified as an MGDS Q-List item important to safety and waste isolation. ${ }^{[1]}$ The waste package is on the Q-List by direct inclusion by the Department of Energy (DOE); a Quality Administrative Procedure (QAP)-2-3 evaluation has yet to be conducted. There are no applicable determination of importance evaluations in accordance with Nevada Line Procedure (NLP)-2-0. The preparation, review, and content of this technical document are covered by three Waste Package Development Department (WPDD) QAP-2-0 work control Activity Evaluations:

1. Develop Technical Documents ${ }^{[6]}$

2. Formal Review of Technical Documents ${ }^{[7]}$

3. Perform Criticality, Thermal, Structural, and Shielding Analyses ${ }^{[2]}$

The Activity Evaluations determine the activities to be subject to Quality Assurance Requirements and Description ${ }^{[3]}$ (QARD) controls. The first and second Activity Evaluations above determined that Management and Operating Contractor (M\&O) QAP-3-5 (Development of Technical Documents) would be followed in the development, review, approval, and any subsequent revision of this technical document. Accordingly, a Technical Document Preparation Plan ${ }^{[9]}$ (TDPP) for this document was developed, issued, and utilized to guide its preparation. Other applicable procedural controls not specifically discussed in the TDPP are listed in the above mentioned QAP-2-0 evaluations.

The third Activity Evaluation above determined that M\&O QAP-3-9 would be followed for the performance of all calculations in support of this technical document. Four supporting QAP-3-9 design analyses were developed which provide the bulk of the input to this report:

1. Determination of PWR SNF Effective Conductivity ${ }^{[48]}$

2. Determination of $7 \times 7$ Rod Array BWR SNF Assembly Effective Thermal Conductivity ${ }^{[49]}$

3. Determination of $8 \times 8$ Rod Array BWR SNF Assembly Effective Thermal Conductivity ${ }^{[50]}$

4. Determination of $9 \times 9$ Rod Array BWR SNF Assembly Effective Thermal Conductivity ${ }^{[51]}$

All calculations performed in support of this technical document are described in the design analyses listed above. The design analyse ${ }^{[48,49,50,51]}$ are for preliminary design and contain unqualified/unconfirmed data and assumptions. These input data and assumptions will require further confirmation as the waste package design proceeds. The finite element analysis (FEA) computer code used for the analyses is ANSYS Version 5.1 which has been qualified for use in quality affecting work in accordance with the M\&O QAP-SI-series procedures and is identified with the Computer Software Configuration Item (CSCI) Identifier 30003 V5.1HP. ANSYS is a commercially available finite element thermal and mechanical analysis code and is appropriate for the thermal analysis of waste packages, waste package emplacements, and the SNF assemblies within the waste package. The use of all computer software in the above design analyses has been controlled in accordance with QAP-3-9 and the QAP-SI-series procedures. 
Distribution of this document will be controlled in accordance with M\&O QAP-6-1, and QA records generated will be handled in accordance with M\&O QAP-17-1. The development of the effective thermal conductivity method for use in waste package thermal evaluations affects no discipline or functional area other than the originating waste package thermal discipline since this evaluation deals with waste package internal conditions/events. Further, this evaluation affects no additional organizations outside of the Waste Package Development Department. Therefore, there are no applicable interfaces having a bearing on this document.

Data and assumptions which are identified in this document are for preliminary design and shall be treated as unqualified; these data and assumptions will require subsequent qualification (or superseding data and assumptions) as the waste package design proceeds. This document will not directly support any construction, fabrication, or procurement activity and therefore is not required to be controlled as TBV (to be verified). In addition, the unqualified/unconfirmed inputs are required to be clearly identified, but are not required to be procedurally controlled as TBV. However, use of any data from this evaluation for input into documents supporting construction, fabrication, or procurement is required to be controlled as TBV in accordance with the appropriate procedures. 


\subsection{Design Requirements and Criteria}

\subsubsection{Waste Package Development Technical Document}

Section 4.2.4.2 of the Waste Package Development Technical Document ${ }^{[17]}$ contains a description of thermal design analyses required for waste package design. The analyses reported in this document were performed to fulfill the requirement that evaluations be performed to determine internal waste package temperatures, including peak SNF cladding temperatures.

\subsubsection{Engineered Barrier Design Requirements Document (EB-DRD)}

The design of the engineered barrier system (EBS) will depend on thermal analyses of the repository host rock, emplacement drifts, waste packages, and the SNF assemblies. Criteria that relate to the thermal analysis of the EBS are derived from the applicable requirements and planning documents. The EB-DRD ${ }^{[16]}$ contains several requirements which relate to peak SNF cladding temperatures considered in this document; however, it is not the intent of the analyses reported here to show direct compliance with the subject requirements. A review of the EB-DRD identified the following relevant requirements:

"The Repository Segment will accommodate the emplacement concept (TBD) selected during ACD. ... The Repository Segment layout will also ensure that the design limit temperatures (TBD) for waste forms are not exceeded."

[EB-DRD 3.2.3.3.A.8.d]

Requirement 3.2.3.3.A.8.d will be addressed by future design analyses that may utilize the SNF effective thermal conductivity method (recommended in Section 8) for the estimation of peak temperatures in the SNF waste form.

"If the design requires the waste form to be transferred for any purpose (such as from shipping casks to waste packages), the Repository Segment is responsible for the following: ...

Repository Segment operations at the surface handling facility will be designed so that cladding failure from mechanical abrasion or deformation considering thermally-induced effects will result in less than five percent (TBV) cladding strain."

[EB-DRD 3.2.3.3.A.10.b]

Requirement 3.2.3.3.A.10.b will be addressed by future design analyses that may utilize the SNF effective thermal conductivity method (recommended in Section 8 ) for the estimation of peak temperatures in the SNF waste form. 
"WA will provide standard SNF meeting the following criteria:

... Cooling: The minimum cooling time for fuel is five (5) years."

[EB-DRD 3.2.3.4.C.1.d]

Requirement 3.2.3.4.C.1.d for Waste Acceptance (WA) is considered in Section 4 where it represents an upper bound for the range of heat loads is assumed for this evaluation (encompassing SNF assemblies with as little cooling time as five years).

"WA will provide standard SNF meeting the following criteria: $\cdots$

Temperature will not have exceeded $350^{\circ} \mathrm{C}$ (TBV) during storage under inert gas."

[EB-DRD 3.2.3.4.C.2]

Requirement 3.2.3.4.C.2 will be addressed by future design analyses that may utilize the SNF effective thermal conductivity method (recommended in Section 8) for the estimation of peak temperatures in the SNF waste form.

"The design of waste packages shall include, but not limited to, consideration of the following factors: solubility, oxidation/reduction reactions, corrosion, hydriding, gas generation, thermal effects, mechanical strength, mechanical stress, radiolysis, radiation damage, radionuclide retardation, leaching, fire and explosion hazards, thermal loads, and synergistic interactions."

[EB-DRD 3.7.1.B]

Requirement 3.7.1.B will be addressed by future design analyses that will utilize the SNF effective thermal conductivity method (recommended in Section 8) for the estimation of peak SNF temperatures to support the thermal design of the waste package .

\subsubsection{ASME Boiler and Pressure Vessel Code}

There are no codes or standards which directly apply to the design of disposal containers. The American Society of Mechanical Engineer (ASME) Boiler and Pressure Vessel Code ${ }^{[8]}$ has been used only as source of material properties in the supporting design analyses. ${ }^{[48,49,50,51]}$ 


\subsection{Design Assumptions}

In the course of developing this document, several assumptions were made regarding the prediction of temperatures within an SNF assembly. The major assumptions along with the assumptions contained in the Controlled Design Assumptions (CDA) Document ${ }^{[18]}$ (TBV-221-DD) are provided below. Documents which use data from this document as input must carry this TBV forward if they are developed in support of construction, fabrication, or procurement.

1.4-1 The discrete SNF assembly model assumes that a two dimensional (2-D) finite element model of a cross section at the midsection of the assembly will be representative of the hottest portion of the assembly. Inherent in this assumption is that axial heat transfer does not significantly affect the solution (i.e., the flow of heat in the radial direction is assumed to dominate the solution). The basis for this assumption is that the metal thermal conductivities and heat generation distributions are such that axial heat transfer is very small or negligible. This was shown by the analyses of References 23 and 26 which modeled a waste package (SNF container) in three dimensions.

1.4-2 For the cross section model of the assembly, an axial power peaking factor of 1.1531 is applied to the PWR SNF heat generation rate and a factor 1.25 is applied to the BWR SNF heat generation rate. These factors are based upon design and reactor operating experience and are assumed to be typical of the range of axial power peaking factors for SNF. ${ }^{[48,49,50,51]}$ The heat loads are multiplied by an axial heat peaking factor to approximate the axial center of the assembly with a 2-D model. An SNF assembly is much hotter at the mid-length than at the ends, and it is conservative to model the hottest cross-section.

1.4-3 The temperatures applied as boundary conditions to the SNF assembly model are assumed to be uniform around the perimeter of the assembly such that a one-quarter model of the assembly is adequate. The hottest SNF assemblies are in the center of a SNF container where temperature gradients in the basket walls are lowest. Assumed uniform temperatures around the assembly allow the use of symmetry to reduce finite element model size.

1.4-4 Heat generation due to the decay of SNF fission products and actinides is assumed to be evenly distributed throughout all of the $\mathrm{UO}_{2}$ pellets. Radial power profiles within the pellets and within the assembly are neglected, and heat generation in the cladding (and other nonfuel hardware) due to activation and radiation energy deposition are ignored. It is conservative to assume that all of the heat produced by the SNF assembly is produced in the $\mathrm{UO}_{2}$ pellet and not in the cladding. Attachment III of Reference 48 provides an analytical discussion of temperature distributions within the pellet and cladding and demonstrates that the highest cladding temperatures result when all of the heat is produced in the pellet. 
1.4-5 Components of the SNF assembly ( $\mathrm{UO}_{2}$, cladding, guide tubes, etc.) are assumed not to touch the SNF basket wall or each other. While the $\mathrm{UO}_{2}$ pellets will likely have swelled and cracked after use in a reactor, it is conservative to assume that there is no conductive contact between the pellet and the cladding such that all heat is transferred by thermal radiation and gaseous (assumed helium, neglecting the effect of fission gas release) conduction across a gap. Also, some spent fuel rods may have bowed such that they contact each other or the SNF basket. Again, it is conservative to assume that heat is transferred only through the fill gas or by radiation.

1.4-6 Fuel irradiation effects are neglected for the purpose of determining material properties in the SNF assembly models. The irradiation of $\mathrm{UO}_{2}$ pellets induces several changes in the porosity, composition, and stoichiometry of the fuel. These changes, however, are generally small in light water reactors. Introduction of fission products into the fuel with burnup and fuel material cracking under thermal cycling lead to a slight decrease in the conductivity; however, these effects are neglected. Also neglected are the effects of fuel densification, swelling, restructuring, and plutonium content; and the oxygen-to-metal ratio of the uranium fuel is assumed to be the theoretical value of 2 . All of these above neglected effects may affect temperatures within the pellet; however, they will have little or no impact on the determination of cladding temperatures, which is the purpose of this evaluation. Zircaloy thermal conductivity is primarily a function of temperature; however, other characteristics such as residual stress levels, crystal orientation, and minor composition differences (Zircaloy-2 versus Zircaloy-4, for example) may have secondary influences on conductivity. These effects as well as cladding dimensional changes (creepdown, thermal expansion, elastic deformation, stress irradiation growth) have been neglected in this evaluation.

1.4-7 The waste package (and therefore the SNF basket containing the SNF assembly) is assumed to be evacuated and possibly filled with helium, nitrogen, or argon gas or left as a vacuum. The basis for this assumption is that the backfill gas/vacuum process is considered on pages II.A.3-20, II.A.3-53, and II.A.4-2 of Reference 13 as a method to meet the internal humidity requirement for the Multi-Purpose Canister (MPC) internals and is presented in the SNF storage cask experiments presented in References 20, 21, 23, 24, and 25.

1.4-8 Convective heat transfer through the fill gas of the SNF assembly is neglected. Modeling only conduction and radiative heat transfer is assumed to provide conservative results for this evaluation. The basis for this assumption is as follows: some convective heat transfer will occur with the fill gas which is placed internal to the SNF container; however, in a horizontal emplacement configuration, convection is minor compared to thermal radiation (at expected temperatures) and stable convection cells either do not develop or are difficult to predict. Also, some fill gases such as helium have poor buoyancy compared to their conductivity (unlike air for example) and the natural convective heat transfer will have a negligible contribution to the total heat transfer (see Reference 11 for a discussion on natural convection heat transfer). Thus, the problem may be modeled with only the dominant heat transfer modes with a negligible or conservative impact upon the results. 
1.4-9 It is assumed for this evaluation that the waste package will not have filler material placed inside of it. The basis for this assumption is that the consideration of filler material between the SNF rods is beyond the scope of this evaluation. Evaluation of the effect of filler materials may be evaluated with additional analyses at a later time.

1.4-10 Insulating the cladding and dominating emissivity, the PWR cladding is assumed to have a nominal $50.8 \mu \mathrm{m}$ ( 2 mils) thick zirconium dioxide layer on its outer surface, and the BWR cladding is assumed to have a nominal $101.6 \mu \mathrm{m}$ (4 mils) thick zirconium dioxide layer on its outer surface. Typical of fuel that has been used in a reactor, the cladding will have oxide layers built up. As seen on page 2.1.3.1-3 of the Waste Form Characteristics Report, ${ }^{[12]}$ $50 \mu \mathrm{m}$ (about 2 mils) is a conservative maximum thickness for PWR SNF with a burnup of around $40 \mathrm{GWd} / \mathrm{MTU}$ (see Assumption 1.4-13). BWR environments induce significantly thicker cladding oxide layers for BWR SNF burnups in the 40 to $50 \mathrm{GWd} / \mathrm{MTU}$ range (see Assumption 1.4-14). The 4 mil BWR oxide layer represents the upper bound based upon BWR design experience. ${ }^{[49,50,51]}$ This evaluation does not consider the build up of crud or other types of substances which may encountered, for example, crud build up experienced by those BWR plants having water chemistry problems. Surface emissivities are significantly affected by surface layers on the cladding (crud usually increases emissivity); therefore, the assumed oxidation layer and any exposed zircaloy surfaces are assumed to have the emissivity resulting from MATPRO Equation 4.1-8 ${ }^{[10]}$ (about 0.8 ) using the above oxidation thicknesses.

1.4-11 The SNF basket opening in the PWR and BWR SNF assembly models are assumed to be $0.2235 \mathrm{~m}$ (8.8 inches) square and $0.1524 \mathrm{~m}$ (6.0 inches) square, respectively; and the basket wall is assumed to have a thickness of $0.01 \mathrm{~m}$. The basket cell width dimensions for PWRs and for BWRs are consistent with conceptual designs for the MPC ${ }^{[13]}$ and current PWR and BWR uncanistered fuel (UCF) WP conceptual designs. ${ }^{[15,27]}$ The basket cell wall thickness is inconsequential as basket wall temperature boundary conditions are applied to the inside wall surface in the finite element model.

1.4-12 For the SNF assembly models, nine basket (boundary) temperatures will be considered: 25 , $50,100,150,200,250,300,350$, and $400^{\circ} \mathrm{C}$. This range will bound the possible operational range of SNF environments for repository disposal; from potential repository ambient rock temperatures of about $25^{\circ} \mathrm{C}^{[26]}$ to greater than the SNF cladding limit of $350^{\circ} \mathrm{C}$. Thermal radiation heat transfer within the assembly introduces temperature nonlinearities resulting in a temperature-dependence in the calculation of effective thermal conductivities for the SNF assembly. Due to the nonlinearities, superposition cannot be applied and the model must be evaluated at a variety of temperature levels.

1.4-13 For the PWR SNF assembly models, four SNF heat loads will be considered: 250, 500, 750, and 1000 watts. This range will encompass as much of the SNF that could be loaded into an SNF disposal container as possible. SNF heat loads vary greatly depending on the age (time since discharge from the reactor), burnup, and other assembly design characteristics. For comparison, a PWR design basis ${ }^{[28]}$ of 10 years old and $48 \mathrm{GWd} / \mathrm{MTU}$ burnup generates 
an initial 850 watts, and an assumed repository average ${ }^{[26]}$ of 22 years old and 42.2 GWd/MTU burnup generates 487 watts.

1.4-14 For the BWR SNF assembly models, six SNF heat loads will be considered: 100, 200, 300, 400,500 , and 600 watts. This range will encompass as much of the SNF that could be loaded into an SNF disposal container as possible. SNF heat loads vary greatly depending on the age (time since discharge from the reactor), burnup, and other assembly design characteristics. For comparison, a BWR design basis ${ }^{[29]}$ of 10 years old and $49 \mathrm{GWd} / \mathrm{MTU}$ burnup generates an initial 409 watts, and an older, but less burned assembly, of 20 years old and $40 \mathrm{GWd} / \mathrm{MTU}$ burnup generates 265 watts. ${ }^{[29]}$

A review of the $\mathrm{CDA}^{[18]}$ identified the following assumptions that are applicable to the analyses described in this report:

Assumption Identifier: $\underline{\text { Key } 008}$ Subject: $\underline{\text { No Rod Consolidation }}$

Rod consolidation will not be performed at the MGDS.

Assumption Identifier: $\underline{\text { Key } 011}$ Subject: $\underline{\text { Horizontal In-Drift Emplacement }}$

Waste packages will be emplaced in-drift in a horizontal mode.

Assumption Identifier: $\underline{\text { Key } 054}$ Subject: $\underline{\text { Normal Waste Handling Building Capability }}$ (No Filler Material)

The design for the WHB's MPC standard handling operations is based on no capability to add filler material to MPCs at the Repository.

Assumption Identifier: DCWP 001 Subject: Limit Fuel Cladding Temperature

Limit the fuel cladding temperature to less than $350^{\circ} \mathrm{C}$. 


\subsection{Background and Technical Approach}

As part of an engineered barrier system for the containment of radionuclides, the waste package, which may include a canistered waste form, must be shown to comply with all regulations and requirements that govern the conditions of the emplaced spent nuclear fuel and the near-field rock at the repository horizon. Temperatures in the WP and near-field host rock are key to radionuclide containment, as they directly affect oxidation rates of the metal barriers and the waste form, and the ability of the rock to impede particle movement. Postclosure release rates are regulated by 10 CFR 60, 10 CFR 960, and 40 CFR 191.

Maximum allowable temperatures are based on material performance criteria and are specified as design goals for the WP/Engineered Barrier design. ${ }^{[19]}$ For SNF, the Commercial Spent Fuel Management Program ${ }^{[30]}$ at Pacific Northwest Laboratory recommended a $380^{\circ} \mathrm{C}$ temperature limit for the cladding to prevent creep rupture failure. A more conservative limiting value of $350^{\circ} \mathrm{C}$ has been selected (CDA ${ }^{[18]}$ DCWP 001) to account for uncertainties in source characteristics as well as heat transfer calculations. Specific characteristics and requirements for the engineered barrier system are discussed in Section 1.3 and Reference 16. Over-prediction of SNF cladding temperatures in a thermal analysis can constrain the waste package design and limit the capacity of potential waste package concepts. Therefore, this report discusses the degree of conservatism present in the different methods for predicting peak cladding temperatures, including the best estimate method developed here.

The method used for WP thermal evaluations involves a four-model approach to determine the timedependent WP thermal behavior. A sub-modeling approach is used because it is not possible to model every emplaced SNF assembly and high-level waste glass log in the potential repository at one time. A three-dimensional (3-D) transient finite element model of the WP emplacement drift and surrounding rock provides the WP surface temperature history for use as a boundary condition in a detailed WP design model. At times greater than 1000 years after emplacement, these temperature predictions are augmented with the results of a 2-D axisymmetric disk model of the entire repository to correct for position within the repository and repository edge effect cooling. WP surface temperatures provide the boundary condition for a more detailed thermal analysis of WP internal structures. Finally, resulting SNF basket wall temperature predictions from the WP model provide the boundary for an estimation of peak SNF cladding temperatures. Cladding temperatures are predicted in the WP model using an effective thermal conductivity defined to represent the heat transfer pathways through a smeared heat source homogeneous SNF assembly model. Cladding temperatures may also be conservatively estimated using an empirical correlation, such as the Wooton-Esptein correlation. ${ }^{[5]}$ This report provides a methodology for the last step of the fourmodel approach where estimated SNF cladding temperatures are predicted. Effective thermal conductivities are defined for PWR and BWR assemblies using detailed models of intact SNF assemblies evaluated over a range of temperatures and heat loads. 


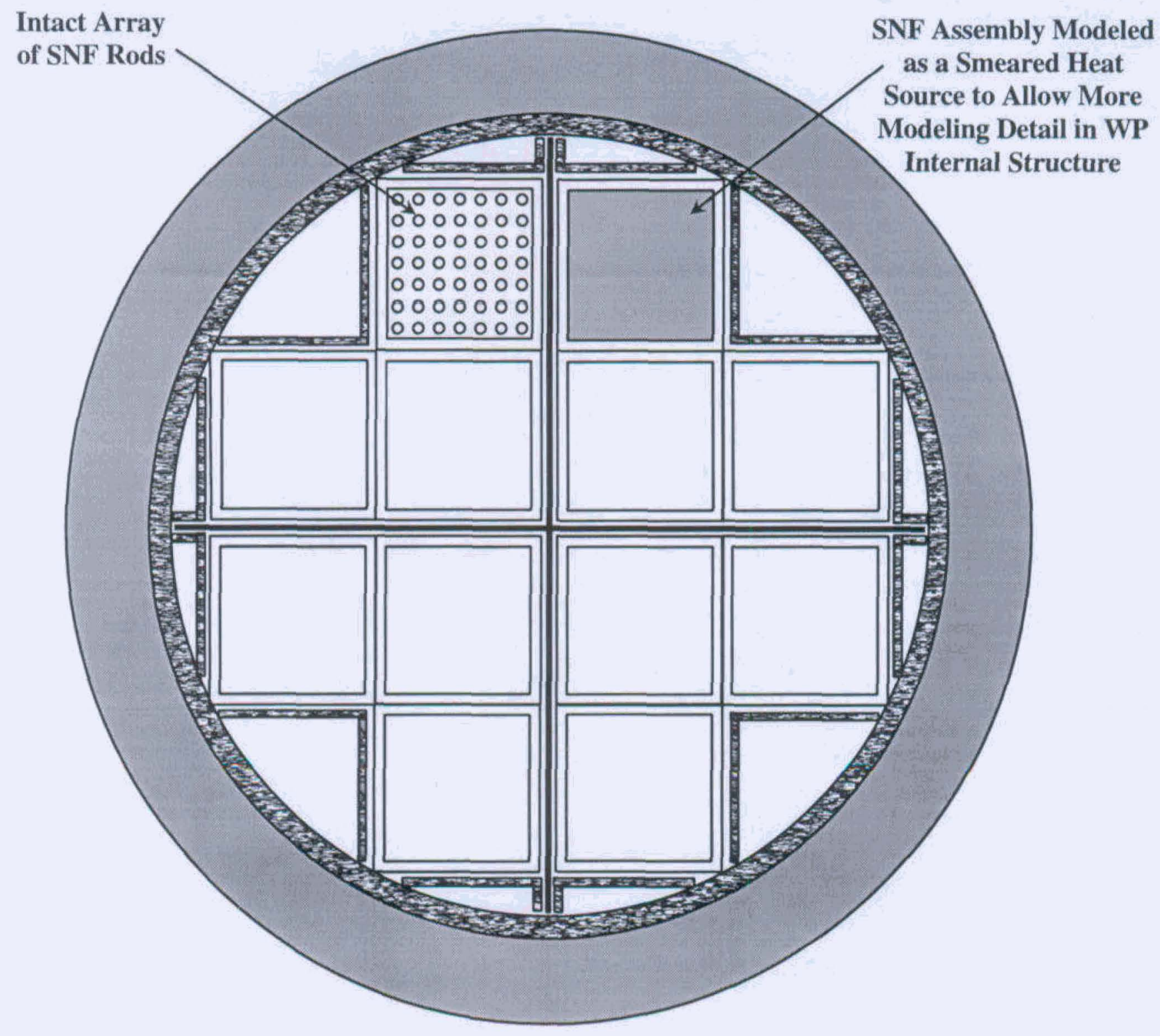

Figure 1.5-1. Waste Package Thermal Model Using SNF Effective Conductivity

Figure 1.5-1 demonstrates the application of the SNF effective thermal conductivity in a thermal analysis of the waste package in repository emplacement. Within the waste package, heat will be transferred from the SNF rods to the WP internal structure via thermal radiation, gas conduction, and convection. The complex processes taking place within the assembly, if modeled, would consume analyst time and computer resources. If the assembly properties and heat are "smeared" (distributed) with effective properties that represent the modes of heat transfer, then more attention can be applied to the details of the waste package device design. While conservatism is desired, too much conservatism can over-constrain the design and possibly limit WP capacity (which would increase overall program cost). Therefore, effective properties for the assembly area should be as close to a "best estimate" as possible. 
To define SNF effective thermal conductivities for use in WP thermal analyses, the finite element analysis method is employed. A finite element representation of the geometry of an SNF assembly was developed for 17x17, 15x15, and 14x14 PWR assemblies, and 9x9, 8x8, and 7x7 BWR assemblies. Models were also developed to compare BWR assemblies with and without channels and with and without water rods. Each model was evaluated over a range of temperatures and assembly heat loads for fill environments of helium, nitrogen, vacuum, and argon using the solid modeling and thermal analysis capabilities of the commercially available ANSYS finite element software. Evaluations were also performed to compare model results to experimental data collected in previous spent fuel storage cask testing. ${ }^{[22]}$

The ANSYS analysis results were used to calculate effective thermal conductivities for homogeneous PWR and BWR SNF assemblies as a function of assembly geometry and fill gas. Trending and comparisons were performed to determine the relevant parameters and to recommend conductivities to be used for conservative and best estimate analyses. SNF cladding temperatures (and resulting effective thermal conductivities, for comparison) were also determined using the Wooton-Epstein Correlation. ${ }^{[5]}$ The calculated effective thermal conductivities were back checked and prediction results for single assemblies and a half cask were compared against storage cask testing results. ${ }^{[22]}$ 


\section{Methods of Predicting Peak Cladding Temperatures}

There are three methods available to estimate cladding temperatures inside a storage, transportation, or disposal device (cask, canister, or container). The first and most involved method is to explicitly model the container and every fuel rod in every assembly within it. This model would directly consider the internal fill gas convection and conduction and a matrix of radiation view factors between the rods. A fluid flow computer code, such as FIDAP (Fluid Dynamics International, Inc.) or COBRA-SFS, ${ }^{[31]}$ could be used to perform such an evaluation. However, the fill gas convection would be dependent upon orientation of the container and the assemblies with respect to both tilt and angle and would be very difficult to quantify. This is especially difficult if the assembly spacer grids are included in the analysis. This method is costly in time of setup and computational time and does not lend itself to parametric evaluation of SNF container design where detail is desired in the basket structure, corrosion barriers, and near field rock; and not in each individual assembly.

The second method employs the Wooton-Epstein ${ }^{[5]}$ correlation to estimate the peak cladding temperature based on the highest steady state temperature in the SNF basket structure. The WootonEpstein correlation has historically been the primary tool of transportation/storage cask vendors as it simplifies the analysis and has been previously accepted by the Nuclear Regulatory Commission (NRC). Thermal analyses of the MPC conceptual design ${ }^{[13]}$ (for storage and transportation) and the BR-100 spent fuel shipping cask ${ }^{[32]}$ used HEATING and PATRAN-P/THERMAL, respectively, to calculate SNF basket temperatures which are the input to Wooton-Epstein. In these models, the SNF assemblies are modeled only as an edge heat flux to the basket structure without internal heat generation. The Wooton-Epstein correlation then generates the estimated maximum steady state spent fuel cladding temperature. This method is not suited for waste package evaluations as it requires lengthy and multiple calculations, does not easily address transient behavior of the SNF and basket, does not easily predict the effects of differential loading of the canister, and may adversely affect basket profiles by forcing constant SNF assembly surface heat flux rates. Given design time requirements, this method usually forces the designer to use conservative bounding approaches to the analysis which tend to over-design the final product. Finally, the Wooton-Epstein correlation was developed as an empirical fit to experimental data generated in 1963 using a single assembly array $(17 \times 18)$ in air with assembly axial power distribution neglected. Despite limitations, the correlation has been shown to be conservative for the thermal evaluations of SNF in a storage or shipping container ${ }^{[32]}$ SNF temperatures calculated in this document are compared to the WootonEpstein correlation predictions in Section 5.

The third method of estimating peak clad temperatures is to prepare a finite element or finite difference model of the SNF assembly volume as a smeared solid with uniform internal volumetric heat generation as part of the entire disposal container model. Instead of explicitly modeling the SNF rods, smeared (distributed) properties for a homogeneous assembly are assumed in the container model that will estimate the combined radiation and gaseous transport of heat from the assembly rods to the basket structure. An effective thermal conductivity for the assembly volume can be defined that will simulate the temperature drop across a PWR or BWR assembly. If the effective thermal conductivity is chosen carefully, the finite element model (FEM) will predict peak temperatures in the smeared-property assembly volume that are close to actual expected 
temperatures. This method has been utilized, in a limited manner, for the designs of the GA-4 $4^{[33]}$ and GA- $9^{[34]}$ truck casks and by the national laboratories which have been tasked by the NRC to verify vendor calculations for the GA-4, BR-100, and other storage and transportation casks. The effective thermal conductivity method can predict cladding temperatures with reasonable accuracy and provides a straightforward method for the determination of transient behavior that will be experienced with repository emplacement.

The key to accurate SNF cladding temperature predictions using the effective thermal conductivity method lies in determining the proper conductivity to assume in the assembly volume. The WootonEpstein correlation demonstrates that peak cladding temperatures are a function of the assembly type, the assembly decay heat, and the SNF basket wall temperature. It is important to note that the SNF basket wall temperature not only specifies the environment temperature for the assembly, but it also impacts what portion of the decay heat will be transferred by thermal radiation which depends on the fourth power of the absolute temperatures (the higher the temperature, the more heat flows by radiation). For an SNF assembly in a gaseous environment, such as the reference helium fill gas, heat will be transferred by gaseous conduction, convection, and radiation. The nonlinear temperature dependence for radiation heat transfer introduces severe nonlinearities into the otherwise linear heat transfer calculation. Therefore, any calculated effective thermal conductivity will be highly temperature-dependent (and nonlinear) and cannot be specified by just one value for a given assembly type.

Due to the limitation of the first two methods, the effective thermal conductivity method will be employed for the parametric thermal evaluation of canistered SNF (such as the MPC) and UCF in multi-barrier waste package designs emplaced in the potential geologic repository at Yucca Mountain. Previous thermal analyses of the conceptual MPC design with disposal container in repository emplacement, ${ }^{[35,36]}$ performed in August 1993, assumed purposely conservative values for effective thermal conductivity due to uncertainties in predicting SNF peak temperatures and in calculating effective thermal conductivities. To determine the appropriate effective thermal conductivity for a PWR or BWR assembly, detailed 2-D models of typical SNF assemblies were developed using the ANSYS finite element code including both gaseous heat transport and thermal radiation. Evaluating a variety of spent fuel characteristics, geometries, and temperature levels (Section 4), temperature and heat-load dependent effective thermal conductivities for homogeneous "smeared" assemblies were derived (Section 6). 


\section{SNF Thermal Model Development}

This section describes the finite element models developed for each of the SNF assembly geometries. While PWR and BWR assemblies experienced very different environments during reactor operation, a similar methodology for predicting peak cladding temperatures can be applied to both for disposal containers. For each geometry, a 2-D cross section of the array of spent fuel rods is assumed. Spacer grids and end plates/fittings are neglected as they have little effect on the net radial heat transfer from the assembly.

Each model assumes a uniform heat generation in the uranium pellets neglecting distributed gamma radiation energy deposition in the cladding and supporting structures. In the future, investigation of volumetric gamma radiation energy distribution within the assembly may be conducted as this distribution may have a small impact on peak cladding temperatures. However, it is conservative to assume that all of heat produced by the SNF assembly is produced in the $\mathrm{UO}_{2}$ pellet and not in the cladding. Attachment III of Reference 48 provides an analytical discussion of temperature distributions within the pellet and cladding and demonstrates that the highest cladding temperatures result when all of the heat is produced in the pellet. Current 2-D waste package thermal models do, however, assume an axial heat peaking factor to approximate the axial power distribution in a spent fuel assembly. Therefore, the volumetric assembly heat, derived from the total SNF assembly heat production, is multiplied by an assembly heat peaking factor of 1.1531 for PWR assemblies and 1.25 for BWR assemblies.

Material properties for the assembly model were taken from several sources including the MATPRO handbook ${ }^{[10]}$ and include temperature-dependent conductivities and oxidation-dependent emissivities. However, other effects such as fuel densification, swelling, restructuring, cladding dimensional changes (creep down, thermal expansion, elastic deformation, stress irradiation growth), and fission product gas release were neglected. The SNF basket is assumed to be stainless steel with a square opening of $0.2235 \mathrm{~m}$ ( 8.8 inches) for PWR assemblies and $0.1524 \mathrm{~m}$ ( 6.0 inches) for BWR assemblies. Material properties for each of the components of the SNF models are specified in detail in the supporting design analyses. ${ }^{[48,49,50,51]}$ 


\subsection{Assembly Fill Environments}

For each model, gaseous conduction and thermal radiation were assumed to transfer heat between the rods. Some fill gases, such as helium, have poor buoyancy compared to their thermal conductivity (unlike air for example), and thus, helium convection heat transfer can be neglected compared to helium conduction in a horizontal assembly. Results of these models representing a horizontal assembly with helium fill gas can also be extrapolated to vertical configurations. Figure 4-18 of The TN-24P PWR Spent-Fuel Storage Cask: Testing and Analyses ${ }^{[23]}$ and BWR Spent Fuel Storage Cask Performance Test; Volume II; Pre-and Post-Test Decay Heat, Heat Transfer, and Shielding Analyses ${ }^{[21]}$ demonstrate that axial convection with helium in a vertical cask is minimal. Axial temperature profiles were largely insensitive to cask orientation with helium compared to nitrogen which exhibited significant axial heat transfer due to convection in a vertical orientation. The similarity between the peak temperatures in the horizontal and vertical helium tests was attributed to the enhanced conduction heat transfer resulting from SNF assemblies contacting the basket compensating for the near-absence of helium convection in the horizontal orientation. ${ }^{[23]}$ Numerous numerical and experimental studies have been conducted for arrays of heat producing rods in a convecting medium, such as those presented in the Radioactive Waste Management conferences or Reference 45 . However, many assume temperatures below $100^{\circ} \mathrm{C}$ (thus minimizing radiation heat transfer), and the results often demonstrate that convection coefficients, Nusselt numbers, flow patterns, etc. are complex and difficult to predict. Fill gases with conductivities much lower than helium, such as nitrogen or argon, may have significant convection effects in a vertical SNF container, but these effects will be minimal in a horizontal configuration. Neglecting convection with fill gases other than helium may result in higher than actual temperature predictions; however, such an assumption is conservative with respect to peak cladding temperatures and the calculations are greatly simplified.

As a base analysis set, helium is utilized as the fill gas of choice; however, the cask designers and manufacturers have stated that alternative fill gas choices may be utilized if desired. The internal environments which have been most commonly discussed in the published literature are helium, vacuum, nitrogen, air, and argon. The thermal properties of nitrogen and air are nearly the same; and therefore, the results for air and nitrogen will be nearly identical with minor or negligible differences. Thus, for the purposes of this evaluation, air will not be examined specifically and the results for air can be considered negligibly different from the results for nitrogen. Each of the models described in this section was evaluated for fill environments of vacuum, nitrogen, and argon as well as the reference fill gas of helium. 


\subsection{PWR Assembly Geometries}

Model detail for the PWR assemblies included a 2 mil thick oxidation layer on the Zircaloy-2 cladding (typical of fuel that has been in a reactor), and a gaseous (assumed helium) gap between the uranium oxide pellet and the cladding. PWR assembly characteristics do not vary greatly; however, to bound the types of assembly geometries, three sizes $(17 \times 17,15 \times 15$, and $14 \times 14)$ were modeled. For previous SNF analyses, ${ }^{[38]}$ a $15 \times 15$ geometry has been assumed the reference (nominal) for WP design. The variability in PWR geometry is discussed here.

\subsubsection{Westinghouse $17 \times 17$}

An intact Westinghouse $17 \times 17$ Standard PWR assembly ${ }^{[12]}$ was chosen as the basis for the 2dimensional model of a $17 \times 17$ assembly which, using symmetry, represents one quarter of an assembly. Assuming two planes of symmetry, the model includes the basket wall, 60 full fuel rods, 12 half fuel rods, 4 full guide tubes, 4 half guide tubes, and one quarter of the center instrument tube. The assembly dimensions used are given in Table 3.2-1.

Table 3.2-1. Westinghouse 17x17 PWR Assembly Dimensions ${ }^{[4,12,48]}$

\begin{tabular}{|c|c||}
\hline Number of Rods & 264 \\
\hline Rod Pitch & $12.60 \mathrm{~mm}(0.496 \mathrm{in})$. \\
\hline $\mathrm{UO}_{2}$ Pellet Diameter & $8.19 \mathrm{~mm}(0.3225 \mathrm{in})$. \\
\hline Cladding Outer Diameter & $9.50 \mathrm{~mm}(0.374 \mathrm{in})$. \\
\hline Cladding Thickness & $0.572 \mathrm{~mm}(0.0225 \mathrm{in})$. \\
\hline Number of Guide Tubes & 24 \\
\hline Guide Tube Outer Diameter & $12.04 \mathrm{~mm}(0.474 \mathrm{in})$. \\
\hline Guide Tube Thickness & $0.406 \mathrm{~mm}(0.016 \mathrm{in})$. \\
\hline Instrument Tube Outer Diameter & $12.19 \mathrm{~mm}(0.480 \mathrm{in})$. \\
\hline Instrument Tube Thickness & $0.406 \mathrm{~mm}(0.016 \mathrm{in})$. \\
\hline Active Fuel Length & $3657.6 \mathrm{~mm}(144.0 \mathrm{in})$. \\
\hline
\end{tabular}




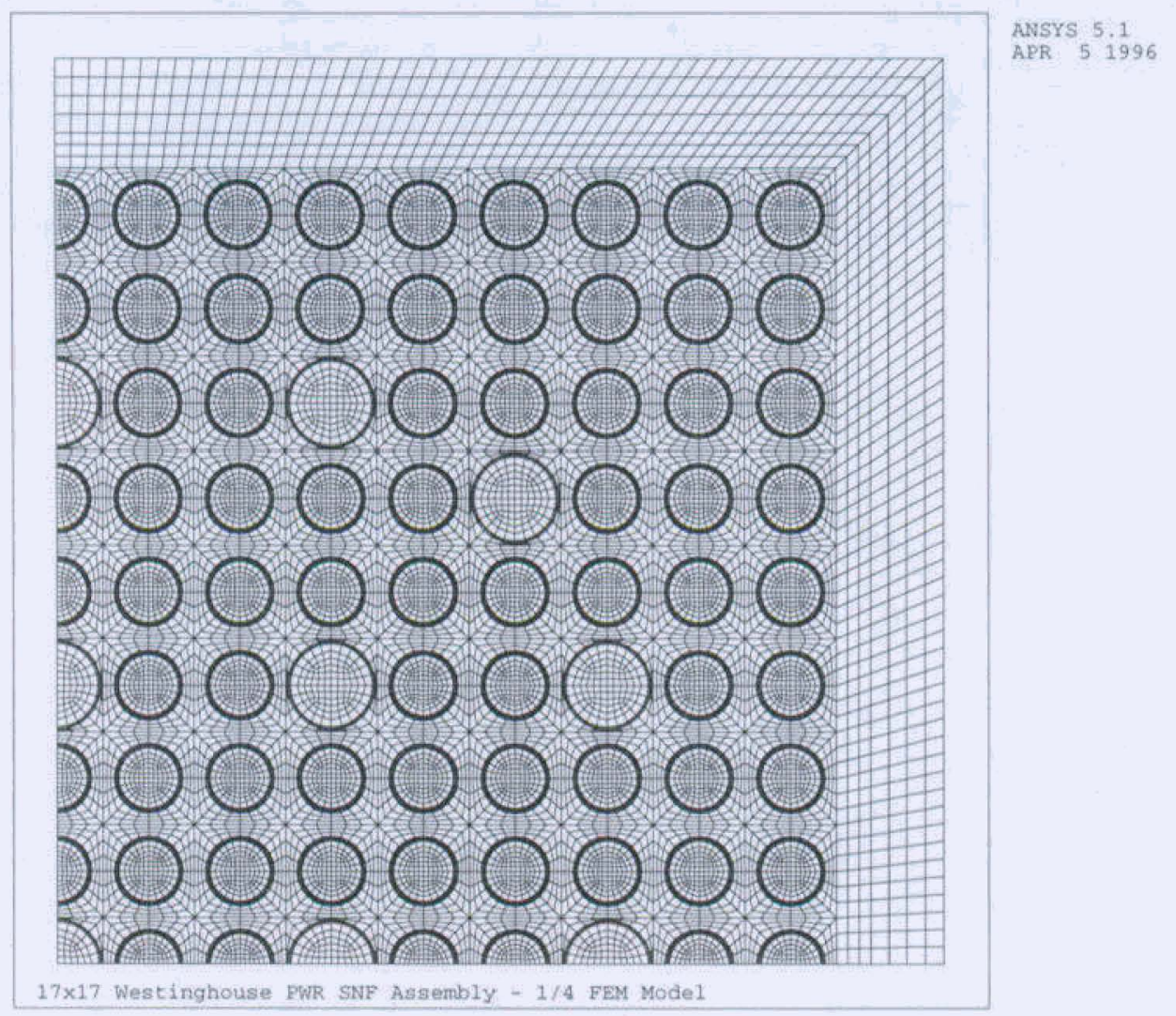

Figure 3.2-1. Finite Element Model, Westinghouse 17x17 PWR Assembly

Figure 3.2-1 displays the finite element model (FEM) mesh developed. Using 24 circumferential elements around each spent fuel rod and a fill gas between the rods, the resulting FEM model has over 23 thousand elements. This represents a higher level of detail than other previous evaluations, such as the safety analysis for the NAC Storable Transport Cask which assumed 8 circumferential elements around the SNF rod. ${ }^{[37]}$

Radiation heat transfer within the assembly will introduce a nonlinear effect to the thermal analysis. Due to the nonlinearities, superposition cannot be applied and the model must be evaluated at a variety of temperature levels. The boundary temperatures will range from the highest SNF basket temperatures expected (when the emplaced waste package internal temperatures peak) to ambient repository rock conditions (the coldest the waste package could be). To model the radiation heat transfer, a matrix of radiation view-factors was explicitly generated for each element face on the surface of the SNF cladding and the basket wall using a radiation matrix super-element utility in the ANSYS code. This method was also applied to model the radiation heat transfer between the fuel pellet surface and the inner surface of the cladding. Figure 3.2-2 displays the thermal radiation edge elements used to generate the matrix. Radiation energy is exchanged between surfaces that can "see" each other using view factors calculated explicitly for the geometry of the array of fuel rods. 


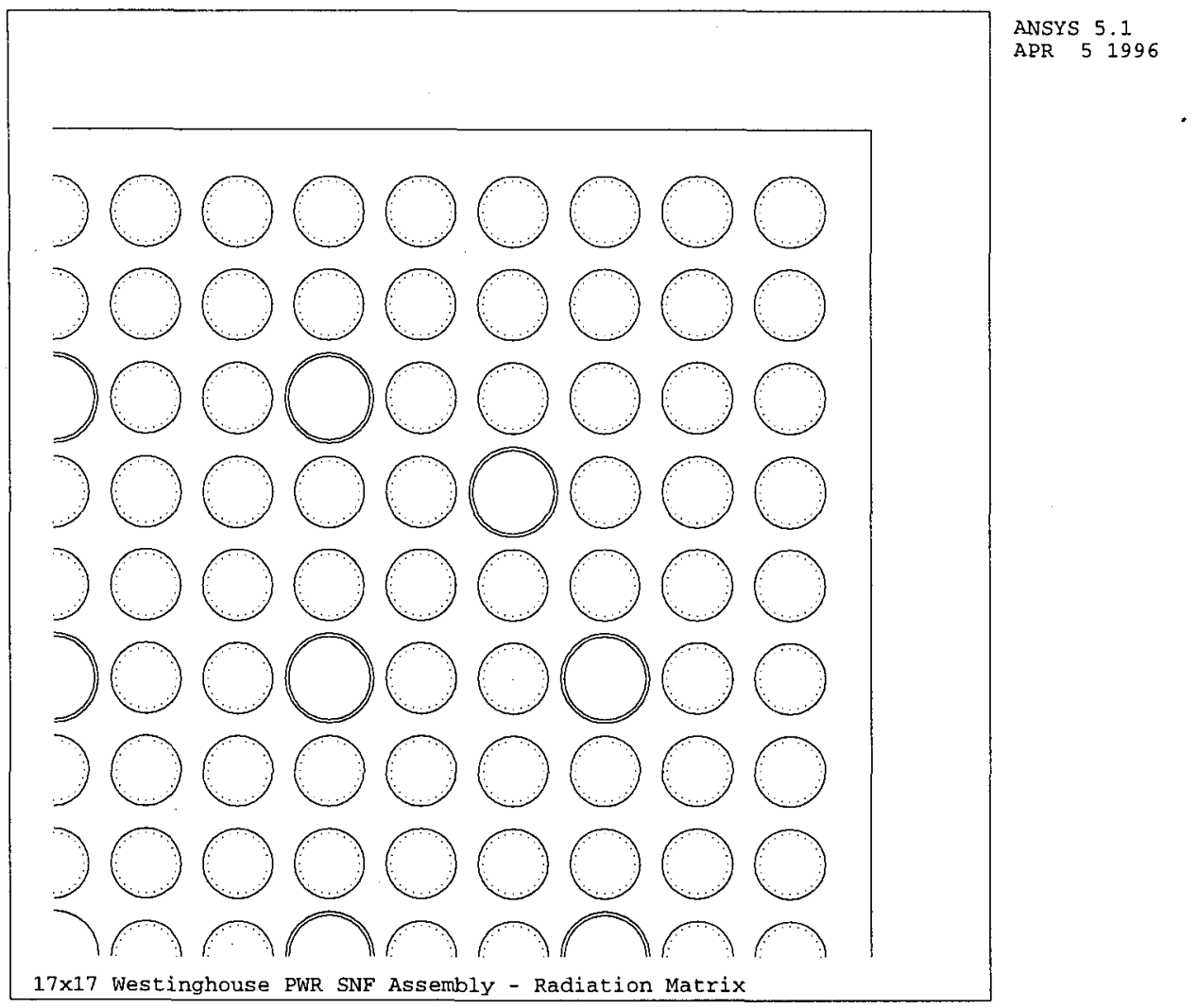

Figure 3.2-2. Thermal Radiation Surfaces, Westinghouse 17x17 PWR Assembly

\subsubsection{Babcock \& Wilcox $15 \times 15$}

An intact Babcock \& Wilcox (B\&W) 15x15 Mark B4 PWR assembly ${ }^{[4]}$ was chosen as the basis for the 2-dimensional model of a $15 \times 15$ assembly which, using symmetry, represents one quarter of an assembly. Assuming two planes of symmetry, the model includes the basket wall, 45 full fuel rods, 14 half fuel rods, 4 guide tubes, and one quarter of the center instrument tube. The assembly dimensions used are given in Table 3.2-2.

Figure 3.2-3 displays the FEM mesh developed. Using 24 circumferential elements around each spent fuel rod and a fill gas between the rods, the resulting FEM model has over 18 thousand elements. Radiation heat transfer is handled similar to that described for the $17 \times 17$ PWR assembly. 

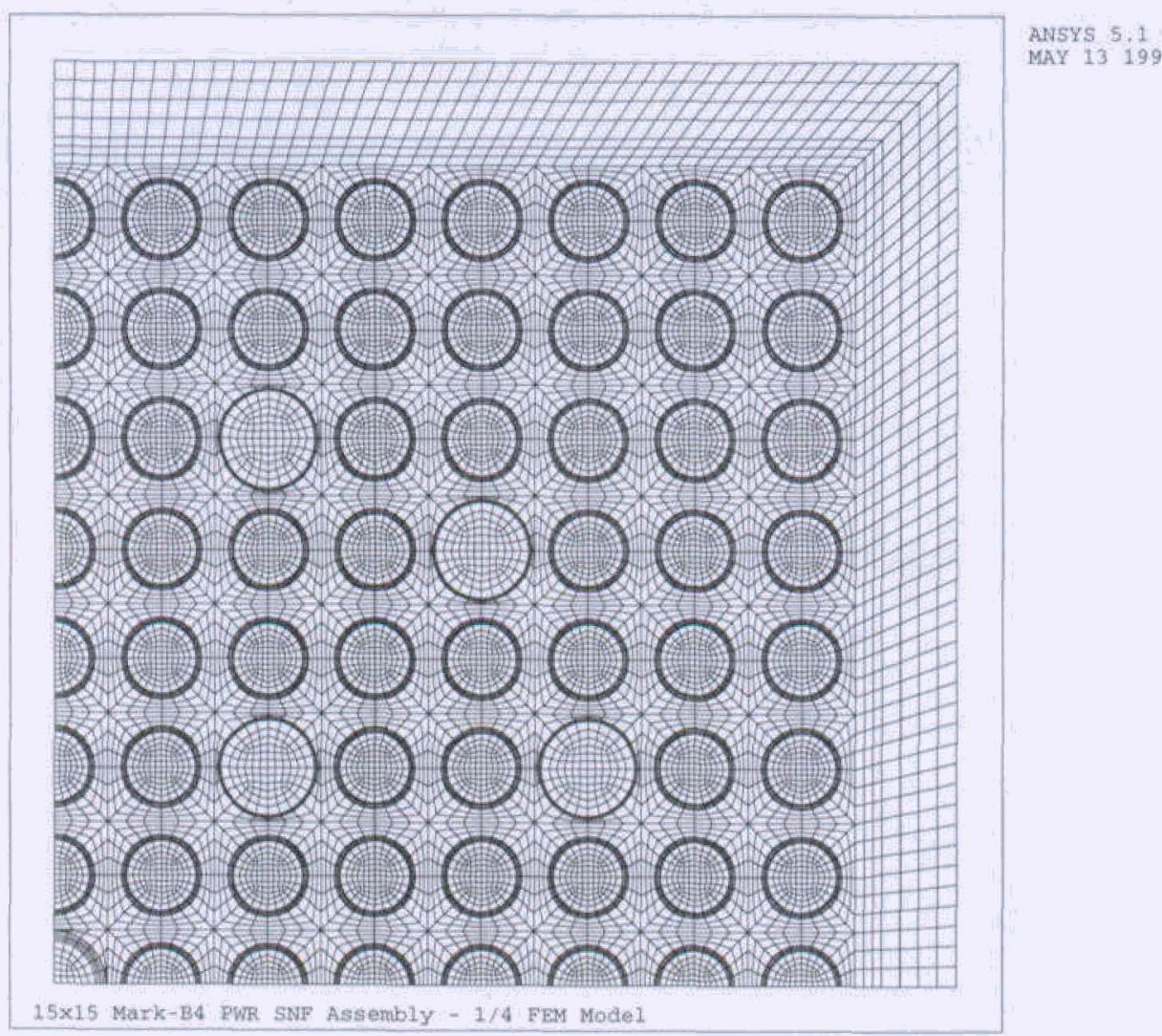

Figure 3.2-3. Finite Element Model, B\&W $15 \times 15$ PWR Assembly

Table 3.2-2. B\&W $15 \times 15$ PWR Assembly Dimensions ${ }^{[4,12,48]}$

\begin{tabular}{||c|c||}
\hline Number of Rods & 208 \\
\hline Rod Pitch & $14.43 \mathrm{~mm}(0.568 \mathrm{in})$. \\
\hline UO $_{2}$ Pellet Diameter & $9.36 \mathrm{~mm}(0.3686 \mathrm{in})$. \\
\hline Cladding Outer Diameter & $10.92 \mathrm{~mm}(0.430 \mathrm{in})$. \\
\hline Cladding Thickness & $0.673 \mathrm{~mm}(0.0265 \mathrm{in})$. \\
\hline Number of Guide Tubes & 16 \\
\hline Guide Tube Outer Diameter & $13.46 \mathrm{~mm}(0.530 \mathrm{in})$. \\
\hline Guide Tube Thickness & $0.406 \mathrm{~mm}(0.016 \mathrm{in})$. \\
\hline Instrument Tube Outer Diameter & $12.52 \mathrm{~mm}(0.493 \mathrm{in})$. \\
\hline Instrument Tube Thickness & $0.660 \mathrm{~mm}(0.026 \mathrm{in})$. \\
\hline Spacer Sleeve Outer Diameter & $14.07 \mathrm{~mm}(0.554 \mathrm{in})$. \\
\hline Spacer Sleeve Thickness & $0.660 \mathrm{~mm}(0.026 \mathrm{in})$. \\
\hline Active Fuel Length & $3601.7 \mathrm{~mm}(141.8 \mathrm{in})$. \\
\hline
\end{tabular}




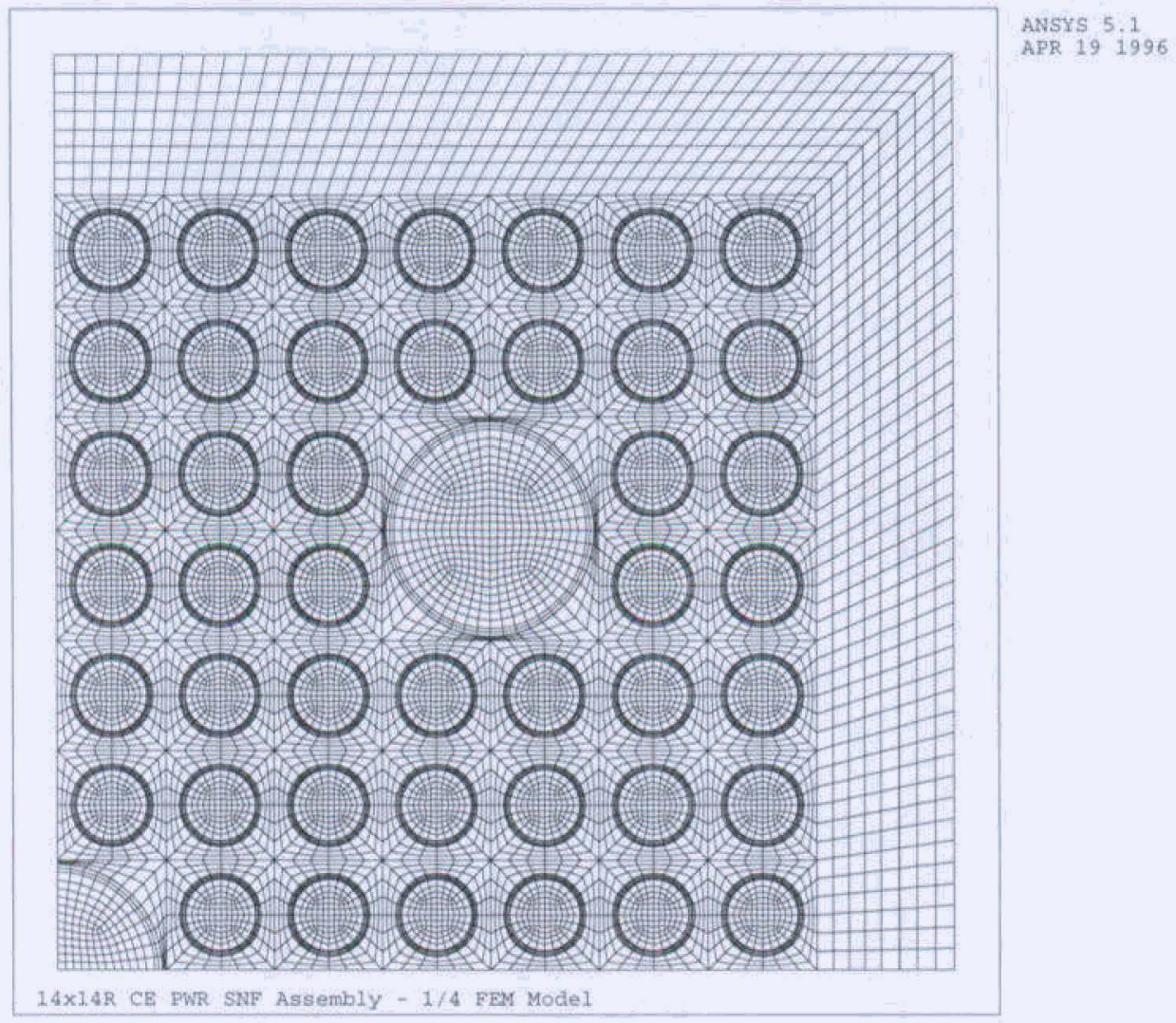

Figure 3.2-4. Finite Element Model, CE 14x14 PWR Assembly

\subsubsection{Combustion Engineering $14 \times 14$}

An intact Combustion Engineering (CE) $14 \times 14 R$ PWR assembly ${ }^{[12]}$ was chosen as the basis for the 2-dimensional model of a $14 \times 14$ assembly which, using symmetry, represents one quarter of an assembly. Assuming two planes of symmetry, the model includes the basket wall, 44 full fuel rods, 1 full guide tube, and one quarter of the center instrument tube. The assembly dimensions used are given in Table 3.2-3.

Figure 3.2-4 displays the FEM mesh developed. Using 24 circumferential elements around each spent fuel rod and a fill gas between the rods, the resulting FEM model has over 15 thousand elements. Radiation heat transfer is handled similar to that described for the 17x17 PWR assembly. 
Table 3.2-3. CE 14x14 PWR Assembly Dimensions ${ }^{[4,12,48]}$

\begin{tabular}{||c|c||}
\hline Number of Rods & 176 \\
\hline Rod Pitch & $14.73 \mathrm{~mm}(0.580 \mathrm{in})$. \\
\hline $\mathrm{UO}_{2}$ Pellet Diameter & $9.56 \mathrm{~mm}(0.3765 \mathrm{in})$. \\
\hline Cladding Outer Diameter & $11.18 \mathrm{~mm}(0.440 \mathrm{in})$. \\
\hline Cladding Thickness & $0.711 \mathrm{~mm}(0.0280 \mathrm{in})$. \\
\hline Number of Guide Tubes & 5 \\
\hline Guide Tube Outer Diameter & $28.32 \mathrm{~mm}(1.115 \mathrm{in})$. \\
\hline Guide Tube Thickness & $1.016 \mathrm{~mm}(0.040 \mathrm{in})$. \\
\hline Active Fuel Length & $3472.2 \mathrm{~mm}(136.7 \mathrm{in})$. \\
\hline
\end{tabular}




\subsection{BWR Assembly Geometries}

Model detail for the BWR assemblies included a 4 mil thick oxidation layer on the Zircaloy-2 cladding (typical of fuel that has been in a reactor), a gaseous (assumed helium) gap between the uranium oxide pellet and the cladding; and a Zircaloy-4 channel with a 6 mil thick oxidation layer. BWR assembly characteristics do vary; however, to bound the types of assembly geometries, three sizes $(9 \times 9,8 \times 8$, and $7 \times 7)$ were modeled. Channel thickness variations are also considered, as well as the number, position, and size of water rods which exist in some BWR assembly designs. The variability in BWR geometry is discussed here.

\subsubsection{Advanced Nuclear Fuels 9x9}

An intact Advance Nuclear Fuels (ANF, previously Exxon Nuclear, and currently Siemens Power Corp.) 9x9 ANF-JP BWR assembly ${ }^{[4]}$ was chosen as the basis for the 2-dimensional model of an $9 \times 9$ assembly which, using symmetry, represents one quarter of an assembly. Assuming two planes of symmetry, the model includes the basket wall, 16 full fuel rods, 8 half fuel rods, 1 quarter fuel rod, and the exterior BWR assembly channel which can be considered to be an integral part of the SNF assembly. For the base case evaluation, a 9x9 BWR design with two fuel-rod-sized water rods was selected; however, the water rod positions are modeled as fuel rods to provide a slightly conservative estimate of peak cladding temperatures. One or two fuel-rod-sized water rods will slightly lower the peak temperature predicted, thus, a model constructed without water rods will be conservatively bounding for peak cladding temperature predictions. Water rod designs are discussed in Section 3.3.5. The assembly dimensions used are given in Table 3.3-1.

Table 3.3-1. ANF-JP 9x9 BWR Assembly Dimensions ${ }^{[4,12,14,51]}$

\begin{tabular}{|c|c|}
\hline Parameter & ANF-JP \\
\hline \hline Number of Rods & 79 \\
\hline Rod Pitch & $14.53 \mathrm{~mm}(0.572 \mathrm{in})$. \\
\hline UO $_{2}$ Pellet Diameter & $9.06 \mathrm{~mm}(0.3565 \mathrm{in})$. \\
\hline Cladding Outer Diameter & $10.77 \mathrm{~mm}(0.424 \mathrm{in})$. \\
\hline Cladding Thickness & $0.76 \mathrm{~mm}(0.030 \mathrm{in})$. \\
\hline Number of Water Rods & 2 \\
\hline Water Rod Outer Diameter & $10.82 \mathrm{~mm}(0.426 \mathrm{in})$. \\
\hline Water Rod Thickness & $0.81 \mathrm{~mm}(0.032 \mathrm{in})$. \\
\hline Channel Inside Width & $134.06 \mathrm{~mm}(5.278 \mathrm{in})$. \\
\hline Channel Thickness & $2.03,2.54$, or $3.05 \mathrm{~mm}$ \\
& $(0.080,0.100$, or $0.120 \mathrm{in})$. \\
\hline Channel Corner Radius & $9.65 \mathrm{~mm}(0.380 \mathrm{in})$. \\
\hline Active Fuel Length & $3810.0 \mathrm{~mm}(150.0 \mathrm{in})$. \\
\hline
\end{tabular}




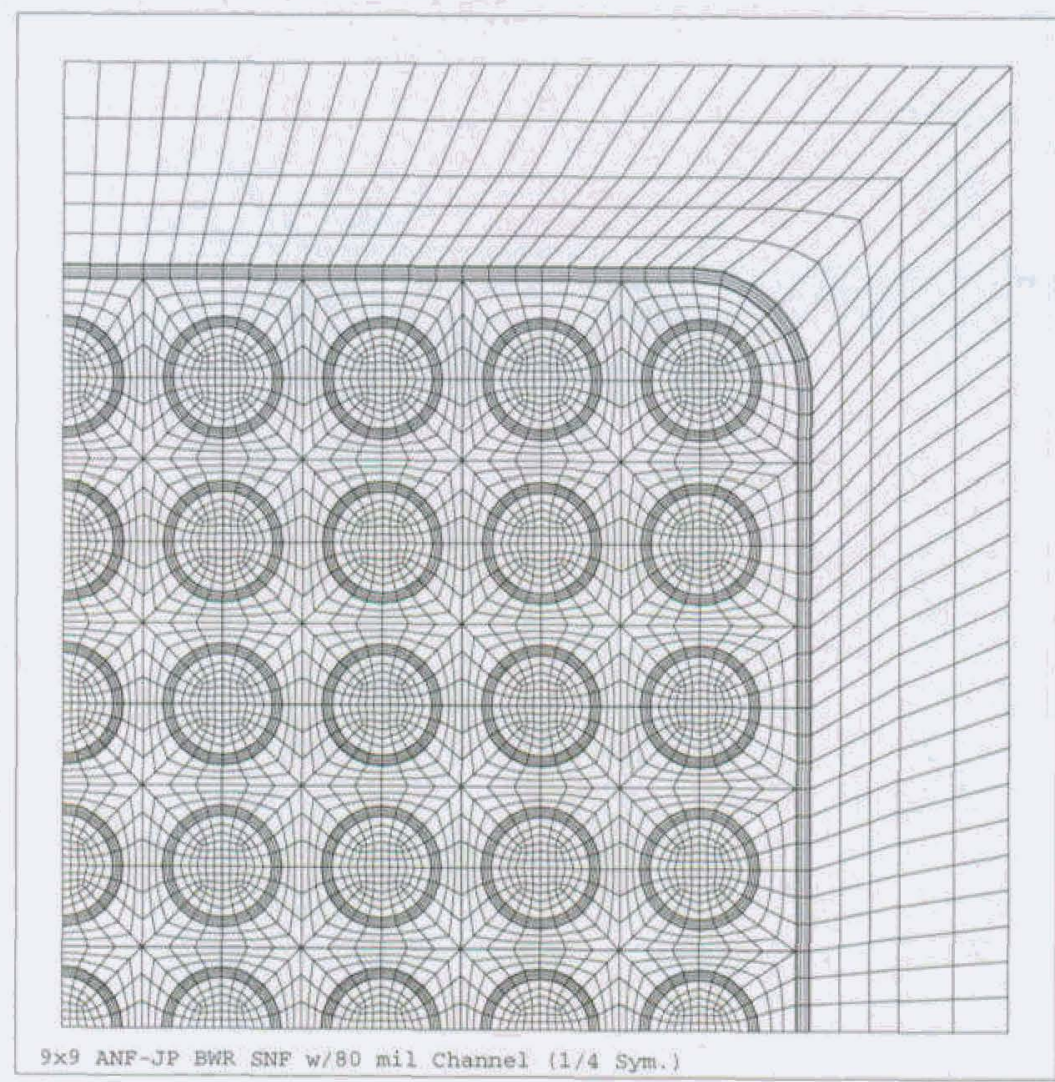

Figure 3.3-1. Finite Element Model, ANF 9x9 BWR Assembly

Figure 3.3-1 displays the FEM mesh developed. Using 24 circumferential elements around each spent fuel rod and a fill gas between the rods, the resulting FEM model has over 6 thousand elements.

Similar to the PWR assemblies, radiation heat transfer within the BWR assembly will introduce a nonlinear effects to the thermal analysis. Due to the nonlinearities, superposition cannot be applied and the model must be evaluated at a variety of temperature levels. The boundary temperatures will range from the highest SNF basket temperatures expected (when the emplaced waste package internal temperatures peak) to ambient repository rock conditions (the coldest the waste package could be). To model the radiation heat transfer, a matrix of radiation view-factors was explicitly generated for each element face on the surface of the SNF cladding, the BWR channel, and the basket wall using a radiation matrix super-element utility in the ANSYS code. This method was also applied to model the radiation heat transfer between the fuel pellet surface and the inner surface of the cladding. Figure 3.3-2 displays the thermal radiation edge elements used to generate the matrix. Radiation energy is exchanged between surfaces that can "see" each other using view factors calculated explicitly for the geometry of the array of fuel rods. 


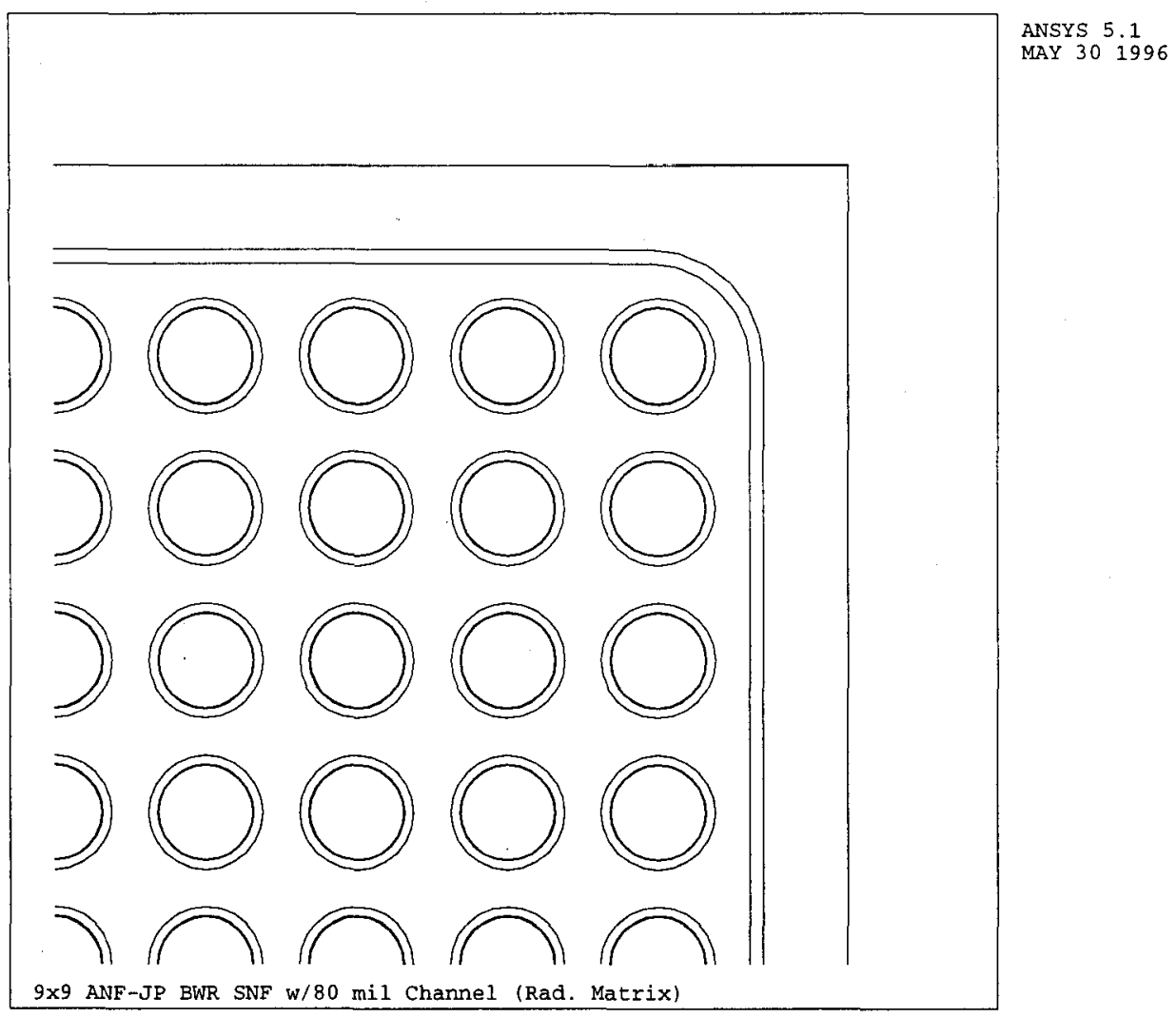

Figure 3.3-2. Thermal Radiation Surfaces, GE 9x9 BWR Assembly

\subsubsection{General Electric $8 \times 8$}

An intact General Electric (GE) $8 \times 8$ GE-5 BWR assembly ${ }^{[4]}$ was chosen as the basis for the 2dimensional model of an $8 \times 8$ assembly which, using symmetry, represents one quarter of an assembly. Assuming two planes of symmetry, the model includes the basket wall, 16 full fuel rods, and the exterior BWR assembly channel which can be considered to be an integral part of the SNF assembly. For the base case evaluation, a 8x8 BWR design with one fuel-rod-sized water rod was selected; however, the water rod position is modeled as a fuel rod to provide a slightly conservative estimate of peak cladding temperatures. The assembly dimensions used are given in Table 3.3-2.

Figure 3.3-3 displays the FEM mesh developed. Using 24 circumferential elements around each spent fuel rod and a fill gas between the rods, the resulting FEM model has over 5 thousand elements. Radiation heat transfer is handled similar to that described for the 9x9 BWR assembly. 


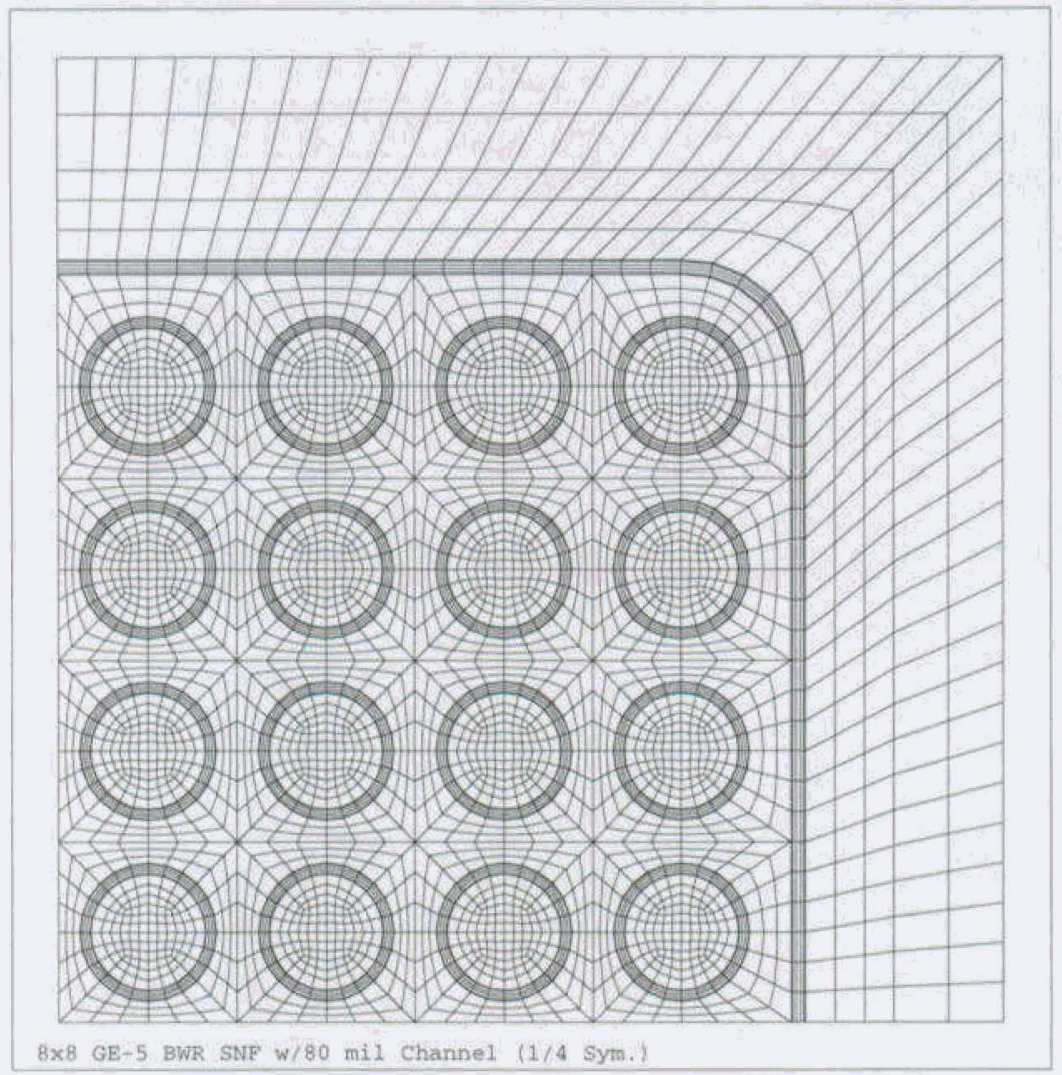

ANSYS 5,1

MAY 251996

Figure 3.3-3. Finite Element Model, GE 8x8 BWR Assembly

Table 3.3-2. GE-5 8x8 BWR Assembly Dimensions $s^{[4,12,14,50]}$

\begin{tabular}{|c|c|}
\hline Number of Rods & 62 to 63 \\
\hline Rod Pitch & $16.26 \mathrm{~mm}(0.640 \mathrm{in})$. \\
\hline UO $_{2}$ Pellet Diameter & $10.41 \mathrm{~mm}(0.410 \mathrm{in})$. \\
\hline Cladding Outer Diameter & $12.27 \mathrm{~mm}(0.483 \mathrm{in})$. \\
\hline Cladding Thickness & $0.8128 \mathrm{~mm}(0.032 \mathrm{in})$. \\
\hline Number of Water Rods & 1 to 2 \\
\hline Water Rod Outer Diameter & $12.45 \mathrm{~mm}(0.490 \mathrm{in})$. \\
\hline Water Rod Thickness & $0.7112 \mathrm{~mm}(0.028 \mathrm{in})$. \\
\hline Channel Inside Width & $12.52 \mathrm{~mm}(5.278 \mathrm{in})$. \\
\hline Channel Thickness & $\begin{array}{c}2.03,2.54, \text { or } 3.05 \mathrm{~mm} \\
(0.080,0.100, \text { or } 0.120 \mathrm{in} .)\end{array}$ \\
\hline Channel Corner Radius & $9.65 \mathrm{~mm}(0.380 \mathrm{in})$. \\
\hline Active Fuel Length & $3810.0 \mathrm{~mm}(150.0 \mathrm{in})$. \\
\hline
\end{tabular}




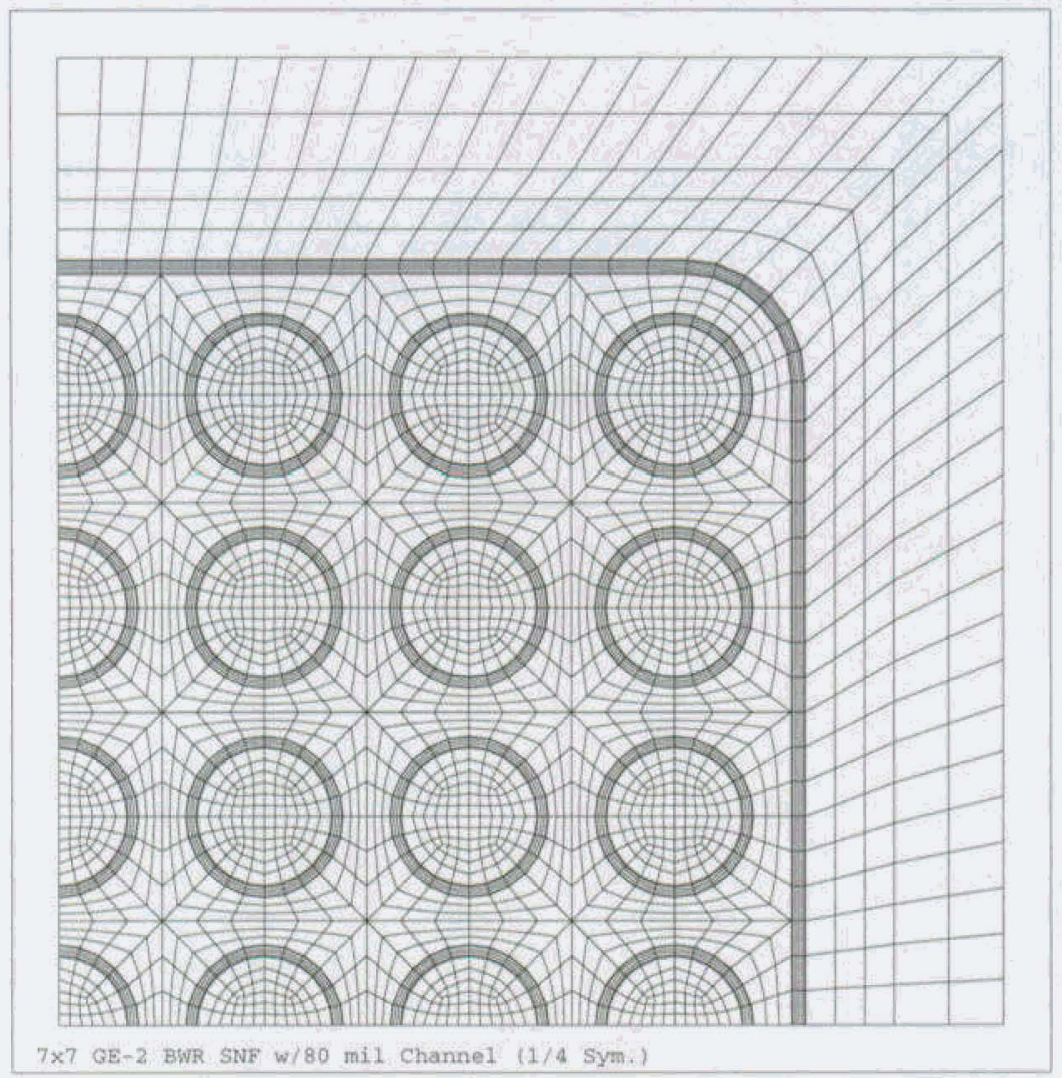

ANSYS 5.1

MAR $27 \quad 1996$

Figure 3.3-4. Finite Element Model, GE 7x7 BWR Assembly

\subsubsection{General Electric 7x7}

An intact GE 7x7 GE-2 BWR assembly ${ }^{[4]}$ was chosen as the basis for the 2-dimensional model of a $7 \times 7$ assembly which, using symmetry, represents one quarter of an assembly. Assuming two planes of symmetry, the model includes the basket wall, 9 full fuel rods, 6 half fuel rods, 1 quarter fuel rod, and the exterior BWR assembly channel which can be considered to be an integral part of the SNF assembly. The assembly dimensions used are given in Table 3.3-3.

Figure 3.3-4 displays the FEM mesh developed. Using 24 circumferential elements around each spent fuel rod and a fill gas between the rods, the resulting FEM model has over 5 thousand elements. Radiation heat transfer is handled similar to that described for the $9 \times 9 \mathrm{BWR}$ assembly. 
Table 3.3-3. GE-2 7x7 BWR Assembly Dimensions ${ }^{[4,12,14,49]}$

\begin{tabular}{|c|c||}
\hline Number of Rods & 49 \\
\hline Rod Pitch & $18.75 \mathrm{~mm}(0.738 \mathrm{in})$. \\
\hline $\mathrm{UO}_{2}$ Pellet Diameter & $12.37 \mathrm{~mm}(0.487 \mathrm{in})$. \\
\hline Cladding Outer Diameter & $14.30 \mathrm{~mm}(0.563 \mathrm{in})$. \\
\hline Cladding Thickness & $0.8128 \mathrm{~mm}(0.032 \mathrm{in})$. \\
\hline Number of Water Rods & 0 \\
\hline Channel Inside Width & $134.06 \mathrm{~mm}(5.278 \mathrm{in})$. \\
\hline Channel Thickness & $2.03,2.54$, or $3.05 \mathrm{~mm}$ \\
& $(0.080,0.100$, or $0.120 \mathrm{in})$. \\
\hline Channel Corner Radius & $9.65 \mathrm{~mm}(0.380 \mathrm{in})$. \\
\hline Active Fuel Length & $3657.6 \mathrm{~mm}(144.0 \mathrm{in})$. \\
\hline
\end{tabular}

\subsubsection{Disposal of BWR Assemblies without Channels}

BWR fuel assemblies are manufactured and used in the reactor core with an outer tube enclosure called a channel. The channel is open at the bottom and makes a sliding seal fit on the lower tie plate surface. At the top of the channel, two diagonally opposite corners have welded tabs, one of which supports the weight of the channel from a threaded raised post at one corner of the upper tie plate. The channel is attached using the threaded channel fastener assembly which also includes the fuel assembly positioning spring. Channel-to-channel spacing in a reactor core is provided for by means of spacer buttons located in the upper portion of the channel adjacent to the control rod passage area. The channel enclosing the BWR fuel assemblies for all BWR/2/3/4/5 reactor types has a square cross section with a $134.06 \mathrm{~mm}$ (5.278 inches, nominal) inside width and round corners, each having a $9.652 \mathrm{~mm}\left(0.38\right.$ inches, nominal) inside radius. ${ }^{[14]}$ Three basic types of channels having different wall thicknesses of $2.03,2.54$, and $3.05 \mathrm{~mm}(0.080,0.100$, and 0.120 inches) are currently in production. ${ }^{[14]}$

For SNF container design, including the channel as part of the BWR SNF assembly has some design implications. The channel can:

1) Act as an insulating material in a container by truncating any radiation view factors from the SNF rods to the container internal structures (basket).

2) Provide a path for axial conduction in a container to help evenly distribute the heat load and make heat rejection from the container more efficient.

3) Provide a heat sink for accident conditions. 
4) May or may not provide a conduction contact with the container internal structure for a container in a horizontal position depending upon the orientation of the channel buttons.

In addition to these considerations the container designer must also consider that the BWR assembly channel is removable and thus, the designer may have to design for BWR SNF assemblies which do not have channels.

The base GE-2 7x7 BWR SNF model was generated with a 80 mil channel which was standard issue for the GE-2 fuel assembly series. To assess the impact upon peak cladding temperatures the base 7x7 BWR model was modified to also include the 100 mil and 120 mil channel thicknesses. Additionally, to determine peak cladding temperatures without a channel, the channel material and oxide layer in the base model were removed (redefined as fill gas) including the channel radiation surfaces. This "no channel" (bare assembly) case was considered for each of the BWR geometries (9x9, 8x8, and 7x7) in each of the fill environments (helium, vacuum, nitrogen, and argon). Results are discussed in Section 4.

\subsubsection{BWR Designs with Water Rods}

One of the innovations in the design of BWR fuel assemblies to increase the in-core uranium utilization was the substitution of one or more fuel rods with one or more water rods. A water rod is simply a fuel tube which does not contain any uranium pellets and functions as a conduit to move high density water into the central portion of the fuel assembly at any elevation in the reactor core. One obvious effect of the water rod is to shift the heat generation to the remaining fuel rods and to remove one or more heat generating rods from the center portion of the fuel assembly. Since the peak cladding temperature typically occurs for the center-most fuel rod, BWR SNF assemblies which utilize a water rod could have significantly reduced peak cladding temperatures.

The early $9 \times 9$ designs used at least two, but no more than five fuel-rod-sized water rods in an assembly. The later designs used either two over-sized water tubes to replace four fuel rods each (i.e., a total of eight fuel rods removed) or a single over-sized water tube to replace the nine central fuel rods. Some GE 9x9 designs also used part length fuel rods, but this design has the same effect on peak cladding temperature as a fuel-rod-sized water rod. Since the single over-sized water rod geometry (the ANF-9X design which displaces nine fuel rods) displaces the largest number of central fuel rods, that configuration will have the greatest reduction in peak cladding temperature and will provide a lower bound to all $9 \times 9$ water rod configurations. Thus, for the $9 \times 9$ BWR assembly designs, the limiting water rod design includes a water channel replacing the center nine fuel rods with one single large water channel. Figure 3.3-5 displays the FEM mesh developed for the 9x9 BWR assembly with one large water channel. 


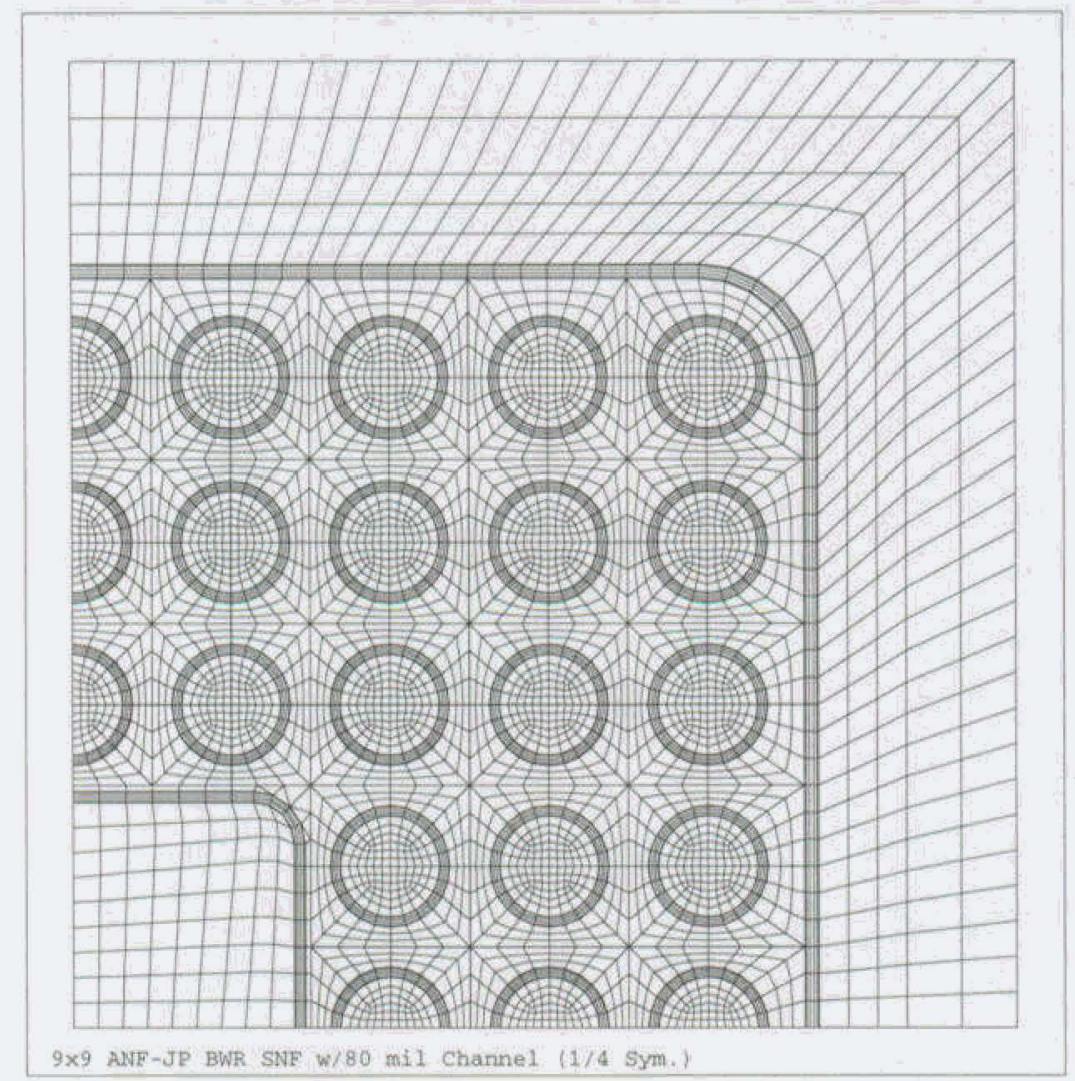

ANSYS 5.1

MAY $30 \quad 1996$

Figure 3.3-5. Finite Element Model, ANF 9x9 BWR Assembly with Water Channel

The $8 \times 8$ BWR assembly designs experienced several design changes over the years with the use of one, two, three, and four fuel-rod-sized water rods near the center of the assembly. This was eventually replaced with one large water rod that displaces the four fuel rods at the center. Since the single over-sized water rod geometry displaces the largest number of central fuel rods, that configuration will have the greatest reduction in peak cladding temperatures and will provide a lower bound to all $8 \times 8$ water rod configurations. Thus, the one large water rod will bound the water rod designs for the $8 \times 8$ assembly and was evaluated here. Figure 3.3-6 displays the FEM mesh developed for the $8 \times 8$ BWR assembly with one large water rod.

The $7 \times 7$ BWR assembly designs were not manufactured with more than one water rod. To address the impact of the water rod on the $7 \times 7$ assembly, the base model was modified by replacing the center fuel rod with a water rod and redistributing the heat among the remaining fuel rods. 


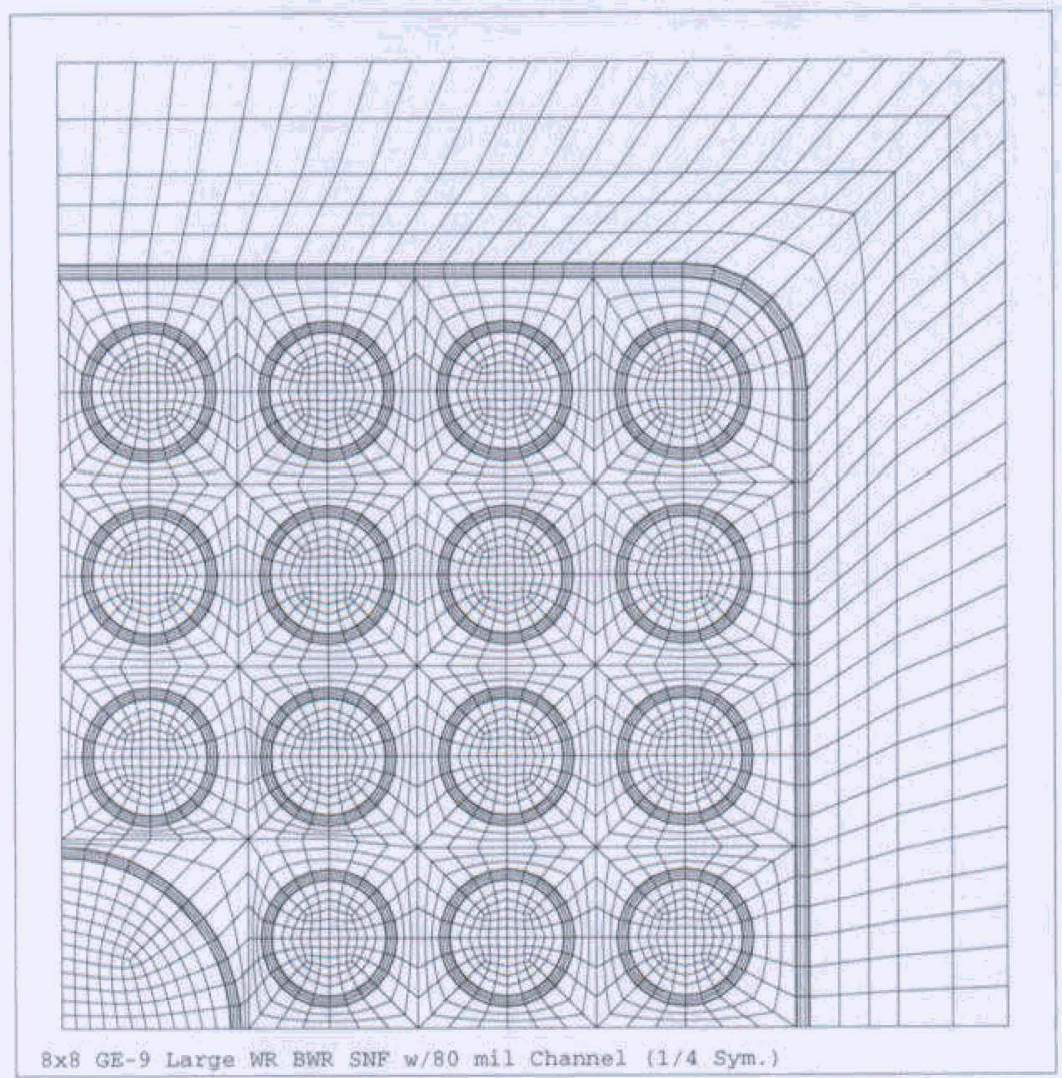

ANSYS 5.1

MAY 281996

Figure 3.3-6. Finite Element Model, GE 8x8 BWR Assembly with Water Rod

One minor complication which must be considered is that BWR reactors historically come in two basic types, C-Lattice and D-Lattice. The difference is that C-Lattice configurations are completely symmetric and the water rod is positioned at the center of the BWR fuel assembly. A D-Lattice configuration is not completely symmetrical and the water rod is placed diagonally adjacent to the fuel rod at the center of the fuel assembly, away from the control blade corner. In terms of peak cladding temperature experienced by the BWR SNF, the two configurations are bounded by the CLattice configuration (water rod in the center) since it positions all of the heat generating fuel rods closer to the outer edge of the fuel assembly. The D-Lattice configuration typically leaves a fuel pin at the center-most location of the BWR fuel assembly which is the least efficient heat rejection position for a fuel pin within the fuel assembly. Therefore, the C-Lattice configuration will have the largest impact (i.e., the largest temperature reduction) on the peak cladding temperature. Thus, only the C-Lattice configuration will be considered for the purpose of bounding the impact upon peak cladding temperatures of a water rod configuration. 
As seen in Figures 3.3-5 and 3.3-6, the C-Lattice water rod configuration was modeled in ANSYS using the base BWR configurations and replacing the center fuel rods with a zircaloy tube water rod (or water channel). The heat generation in the uranium pellets was then adjusted in the remaining fuel rods. The assembly dimensions used for each of the water rod designs $(9 \times 9,8 \times 8$, and $7 \times 7)$ are given in Tables 3.3-4, 3.3-5, and 3.3-6. The water rod configuration was considered for each of the BWR geometries $(9 \times 9,8 \times 8$, and $7 \times 7)$ in each of the fill environments (helium, vacuum, nitrogen, and argon) with and without channels. Results are discussed in Section 4.

Table 3.3-4. ANF 9x9 BWR Assembly with Water Channel Dimensions ${ }^{[4,14,51]}$

\begin{tabular}{|c|c||}
\hline Number of Rods & 72 \\
\hline Rod Pitch & $14.53 \mathrm{~mm}(0.572 \mathrm{in})$. \\
\hline UO $_{2}$ Pellet Diameter & $9.06 \mathrm{~mm}(0.3565 \mathrm{in})$. \\
\hline Cladding Outer Diameter & $10.77 \mathrm{~mm}(0.424 \mathrm{in})$. \\
\hline Cladding Thickness & $0.76 \mathrm{~mm}(0.030 \mathrm{in})$. \\
\hline Number of Water Rods & 1 (Over Sized; Channel Shaped) \\
\hline Water Tube Inside Width & $40.74 \mathrm{~mm}(1.604 \mathrm{in})$. \\
\hline Water Tube Corner Radius & $3.81 \mathrm{~mm}(0.150 \mathrm{in})$. \\
\hline Water Tube Thickness & $0.81 \mathrm{~mm}(0.032 \mathrm{in.})$ \\
\hline Channel Inside Width & $134.06 \mathrm{~mm}(5.278 \mathrm{in.})$ \\
\hline Channel Thickness & $2.03,2.54$, or $3.05 \mathrm{~mm}$ \\
& $(0.080,0.100$, or $0.120 \mathrm{in})$. \\
\hline Channel Corner Radius & $9.65 \mathrm{~mm}(0.380 \mathrm{in})$. \\
\hline Active Fuel Length & $3810.0 \mathrm{~mm}(150.0 \mathrm{in})$. \\
\hline
\end{tabular}


Table 3.3-5, GE-9 8x8 BWR Assembly with Water Rod Dimensions ${ }^{[4,14,50]}$

\begin{tabular}{||c|c||}
\hline Number of Rods & 60 \\
\hline Rod Pitch & $16.26 \mathrm{~mm}(0.640 \mathrm{in})$. \\
\hline UO $_{2}$ Pellet Diameter & $10.41 \mathrm{~mm}(0.410 \mathrm{in.})$ \\
\hline Cladding Outer Diameter & $12.27 \mathrm{~mm}(0.483 \mathrm{in})$. \\
\hline Cladding Thickness & $0.8128 \mathrm{~mm}(0.032 \mathrm{in})$. \\
\hline Number of Water Rods & $1($ Over Sized $)$ \\
\hline Water Tube Outer Diameter & $32.61 \mathrm{~mm}(1.284 \mathrm{in})$. \\
\hline Water Tube Thickness & $0.8128 \mathrm{~mm}(0.032 \mathrm{in})$. \\
\hline Channel Inside Width & $134.06 \mathrm{~mm}(5.278 \mathrm{in})$. \\
\hline Channel Thickness & $2.03,2.54$, or $3.05 \mathrm{~mm}$ \\
& $(0.080,0.100$, or $0.120 \mathrm{in})$. \\
\hline Channel Corner Radius & $9.65 \mathrm{~mm}(0.380 \mathrm{in})$. \\
\hline Active Fuel Length & $3810.0 \mathrm{~mm}(150.0 \mathrm{in})$. \\
\hline
\end{tabular}

Table 3.3-6. ANF 7x7 BWR Assembly with Water Rod Dimensions ${ }^{[4,14,49]}$

\begin{tabular}{||c|c||}
\hline Number of Rods & 48 \\
\hline Rod Pitch & $18.75 \mathrm{~mm}(0.738 \mathrm{in})$. \\
\hline UO $_{2}$ Pellet Diameter & $12.45 \mathrm{~mm}(0.490 \mathrm{in})$. \\
\hline Cladding Outer Diameter & $14.48 \mathrm{~mm}(0.570 \mathrm{in})$. \\
\hline Cladding Thickness & $0.9652 \mathrm{~mm}(0.038 \mathrm{in})$. \\
\hline Number of Water Rods & 1 \\
\hline Water Tube Outer Diameter & $14.48 \mathrm{~mm}(0.570 \mathrm{in})$. \\
\hline Water Tube Thickness & $1.2192 \mathrm{~mm}(0.046 \mathrm{in})$. \\
\hline Channel Inside Width & $134.06 \mathrm{~mm}(5.278 \mathrm{in})$. \\
\hline Channel Thickness & $\begin{array}{c}2.03,2.54, \text { or } 3.05 \mathrm{~mm} \\
(0.080,0.100, \text { or } 0.120 \mathrm{in} .)\end{array}$ \\
\hline Channel Corner Radius & $9.65 \mathrm{~mm}(0.380 \mathrm{in})$. \\
\hline Active Fuel Length & \begin{tabular}{c}
$3657.6 \mathrm{~mm}(144.0 \mathrm{in})$. \\
\hline
\end{tabular} \\
\hline
\end{tabular}




\section{SNF Model Solution Results}

This section describes the solution results for each of the model geometries and fill environments discussed in Section 3. Each case was run on a Hewlett Packard Model 735 Unix workstation and the details of the solution results, including computer printouts, are provided in the supporting design analyses. ${ }^{[48,49,50,51]}$ The solution results presented here provide the input to the calculation of SNF effective thermal conductivities described in Section 6.

\subsection{PWR Assembly Geometries}

A matrix of SNF model solution cases was developed for each of the three discrete PWR assembly models generated in Section 3. The results of these cases will be used to determine the temperature and heat load dependence of the effective thermal conductivities calculated in Section 6. To bound the possible operational range of PWR SNF environments for repository disposal, nine basket temperatures were selected: $25,50,100,150,200,250,300,350$, and $400^{\circ} \mathrm{C}$. This range is intended to cover possible waste package basket temperatures from bounding values greater than the SNF cladding limit of $350^{\circ} \mathrm{C}$ to potential repository ambient rock temperatures of about $25^{\circ} \mathrm{C}^{[26]}$ Four SNF heat loads were also selected based on a range of SNF types that could be received at the repository: $250,500,750$, and 1000 watts. SNF heat loads vary greatly depending on the age (time since discharge from the reactor), burnup, and other assembly design characteristics. For comparison, a PWR design basis ${ }^{[28]}$ of 10 years old and $48 \mathrm{GWd} / \mathrm{MTU}$ burnup generates an initial 850 watts, and one assumed repository average ${ }^{[26]}$ of 22 years old and $42.2 \mathrm{GWd} / \mathrm{MTU}$ burnup generates 487 watts.

\subsubsection{PWR 17x17 Designs}

For the 17x17 PWR model, each of the 36 temperature and heat load cases were evaluated for the reference fill gas of helium and the alternate fill environments of vacuum, nitrogen, and argon. ${ }^{[48]}$ The peak cladding temperature predictions for the helium fill gas case are summarized in Table 4.11. As expected, the highest cladding temperatures occurred for the high basket temperature and high heat load case.

Temperature profiles within the assembly were reasonable as demonstrated in Figure 4.1-1 which displays a sample plot of temperature contours (in degrees $C$ ) for the helium fill gas case with an assembly heat of 750 watts and a basket wall temperature of $300^{\circ} \mathrm{C}$. This case is the most similar to the conditions predicted in the thermal evaluation of the conceptual MPC design with disposal container. ${ }^{[35]}$ That evaluation predicted peak cladding temperatures of $354^{\circ} \mathrm{C}$ and $337^{\circ} \mathrm{C}$ using two conservative estimation methods. An estimate of $317^{\circ} \mathrm{C}$ predicted here indicates a more realistic (less conservative) evaluation of temperatures in an SNF assembly. Benchmarks against reported experimental SNF thermal tests in Section 7.2 and 7.3 indicate that this SNF model provides a "best estimate" of peak temperatures within an SNF assembly. The impact on the determination of effective thermal conductivities is discussed in Section 6. 
Table 4.1-1. Peak Cladding Temperatures, 17x17 PWR Assembly with Helium Fill Gas

\begin{tabular}{||c||c|c|c|c||}
\hline \multirow{2}{*}{$\begin{array}{c}\text { Basket Wall } \\
\text { Temperature }\end{array}$} & \multicolumn{4}{|c||}{ Assembly Heat Load } \\
\cline { 2 - 5 } & 250 watts & 500 watts & 750 watts & 1000 watts \\
\hline $255^{\circ} \mathrm{C}$ & $39^{\circ} \mathrm{C}$ & $52^{\circ} \mathrm{C}$ & $64^{\circ} \mathrm{C}$ & $76^{\circ} \mathrm{C}$ \\
\hline $50{ }^{\circ} \mathrm{C}$ & $63^{\circ} \mathrm{C}$ & $75^{\circ} \mathrm{C}$ & $86^{\circ} \mathrm{C}$ & $97^{\circ} \mathrm{C}$ \\
\hline $100^{\circ} \mathrm{C}$ & $111^{\circ} \mathrm{C}$ & $121^{\circ} \mathrm{C}$ & $131^{\circ} \mathrm{C}$ & $140^{\circ} \mathrm{C}$ \\
\hline $150^{\circ} \mathrm{C}$ & $159^{\circ} \mathrm{C}$ & $168^{\circ} \mathrm{C}$ & $176^{\circ} \mathrm{C}$ & $184^{\circ} \mathrm{C}$ \\
\hline $200^{\circ} \mathrm{C}$ & $208^{\circ} \mathrm{C}$ & $215^{\circ} \mathrm{C}$ & $222^{\circ} \mathrm{C}$ & $230^{\circ} \mathrm{C}$ \\
\hline $250^{\circ} \mathrm{C}$ & $257^{\circ} \mathrm{C}$ & $263^{\circ} \mathrm{C}$ & $269^{\circ} \mathrm{C}$ & $275^{\circ} \mathrm{C}$ \\
\hline $300^{\circ} \mathrm{C}$ & $306^{\circ} \mathrm{C}$ & $311^{\circ} \mathrm{C}$ & $317^{\circ} \mathrm{C}$ & $322^{\circ} \mathrm{C}$ \\
\hline $350^{\circ} \mathrm{C}$ & $355^{\circ} \mathrm{C}$ & $360^{\circ} \mathrm{C}$ & $364^{\circ} \mathrm{C}$ & $369^{\circ} \mathrm{C}$ \\
\hline $400^{\circ} \mathrm{C}$ & $404^{\circ} \mathrm{C}$ & $408^{\circ} \mathrm{C}$ & $413^{\circ} \mathrm{C}$ & $417^{\circ} \mathrm{C}$ \\
\hline
\end{tabular}

Table 4.1-2. Cladding-to-Basket Delta T, 17x17 PWR Assembly with Helium Fill Gas

\begin{tabular}{||c||c|c|c|c||}
\hline \multicolumn{1}{|c|}{$\begin{array}{c}\text { Basket Wall } \\
\text { Temperature }\end{array}$} & \multicolumn{4}{|c||}{ Assembly Heat Load } \\
\cline { 2 - 5 } & 250 watts & 500 watts & 750 watts & 1000 watts \\
\hline \hline $25^{\circ} \mathrm{C}$ & $14^{\circ} \mathrm{C}$ & $27^{\circ} \mathrm{C}$ & $39^{\circ} \mathrm{C}$ & $51^{\circ} \mathrm{C}$ \\
\hline $50^{\circ} \mathrm{C}$ & $13^{\circ} \mathrm{C}$ & $25^{\circ} \mathrm{C}$ & $36^{\circ} \mathrm{C}$ & $47^{\circ} \mathrm{C}$ \\
\hline $100^{\circ} \mathrm{C}$ & $11^{\circ} \mathrm{C}$ & $21^{\circ} \mathrm{C}$ & $31^{\circ} \mathrm{C}$ & $40^{\circ} \mathrm{C}$ \\
\hline $150^{\circ} \mathrm{C}$ & $9^{\circ} \mathrm{C}$ & $18^{\circ} \mathrm{C}$ & $26^{\circ} \mathrm{C}$ & $34^{\circ} \mathrm{C}$ \\
\hline $200^{\circ} \mathrm{C}$ & $8^{\circ} \mathrm{C}$ & $15^{\circ} \mathrm{C}$ & $2 \circ^{\circ} \mathrm{C}$ & $30^{\circ} \mathrm{C}$ \\
\hline $250^{\circ} \mathrm{C}$ & $7{ }^{\circ} \mathrm{C}$ & $13^{\circ} \mathrm{C}$ & $19^{\circ} \mathrm{C}$ & $25^{\circ} \mathrm{C}$ \\
\hline $300^{\circ} \mathrm{C}$ & $6^{\circ} \mathrm{C}$ & $11{ }^{\circ} \mathrm{C}$ & $17^{\circ} \mathrm{C}$ & $2 \circ^{\circ} \mathrm{C}$ \\
\hline $350^{\circ} \mathrm{C}$ & $5^{\circ} \mathrm{C}$ & $10^{\circ} \mathrm{C}$ & $14^{\circ} \mathrm{C}$ & $19^{\circ} \mathrm{C}$ \\
\hline $400^{\circ} \mathrm{C}$ & $4^{\circ} \mathrm{C}$ & $8^{\circ} \mathrm{C}$ & $13^{\circ} \mathrm{C}$ & $17^{\circ} \mathrm{C}$ \\
\hline
\end{tabular}


4

\&ै.

is in

(⿻) in

(1) (1)

을

है छो

(1)
ONOHNmm

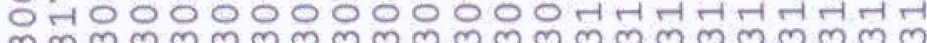

II II

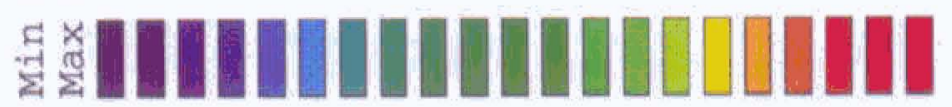

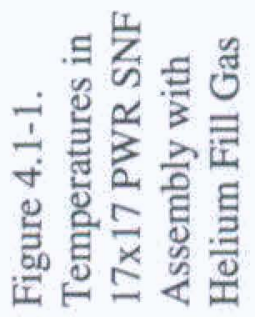

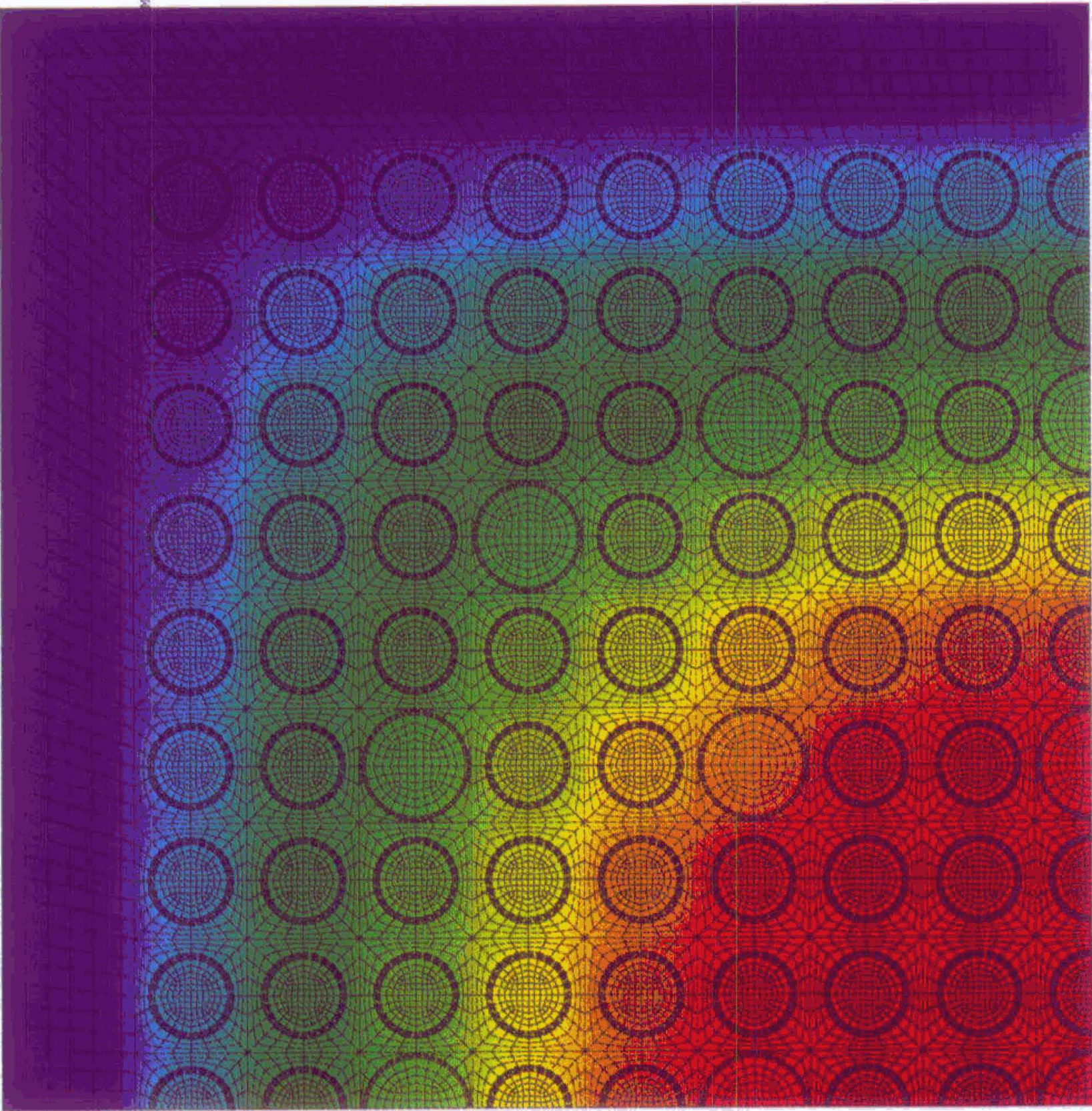


The results in Table 4.1-1 are consistent with the test case results from preliminary calculations ${ }^{[38]}$ and demonstrate some of the expected trending. Table 4.1-2 illustrates this trending by summarizing the cladding-to-basket wall temperature drops $(\Delta \mathrm{T})$ for each case. Without the contribution of thermal radiation as a heat transfer mechanism, one might expect that the temperature drop would depend on the assembly heat load only (that is, $q "=k \cdot \Delta T / L$ ). However, Table 4.1-2 shows that there is a strong nonlinear temperature dependence in the temperature drop which would imply a nonlinear temperature dependence for the effective thermal conductivity $\left(\mathrm{k}_{\mathrm{e}}\right)$ calculated in Section 6.

Because the radiation heat transfer depends on $T^{4}$ (that is, $q^{\prime \prime}=\epsilon \sigma\left(T_{1}^{4}-T_{2}^{4}\right)$ ), there is less thermal resistance as absolute temperatures increase and, therefore, the temperature drop (for a given q") decreases at higher temperatures. As expected, the temperature drop will increase with increasing heat load. The implication is that to define an effective thermal conductivity $\left(\mathrm{k}_{\mathrm{e}}\right)$, such that $q "=k_{e} \cdot \Delta T / L$, the effective thermal conductivity must be temperature-dependent. Because of the multiple nonlinearities involved in an SNF assembly thermal analysis, there may also be a heat load dependence on $\mathrm{k}_{\mathrm{e}}$ as well. Section 6 investigates the trending in the determination of the SNF assembly effective thermal conductivity.

For an assembly with no fill gas (vacuum), it is expected that peak temperatures would be higher due to removal of conduction through helium as a heat transfer pathway. Table 4.1-3 lists the peak cladding temperature difference between no fill gas and the reference fill gas of helium for the $17 \times 17$ PWR assembly. It should be noted that for the tables in this section that report temperature differences between fill gases and assembly designs, the values reported in the supporting design analysis ${ }^{[48]}$ attachments (directly from the ANSYS outputs and not the design analysis summary tables) were compared to avoid round-off errors.

With no fill gas in the assembly, radiation is the only heat transfer mechanism and the temperaturedependent effects observed for helium are more pronounced for vacuum. Compared to helium, vacuum resulted in up to $92^{\circ} \mathrm{C}$ higher temperatures at low basket temperatures, but the rise was less than $10^{\circ} \mathrm{C}$ at high temperatures. This trend indicates that thermal radiation dominates as a heat transfer mechanism at higher temperatures for assemblies with fill gases.

Table 4.1-4 lists the peak cladding temperature difference between nitrogen fill gas and the reference fill gas of helium for the 17x17 PWR assembly. Since nitrogen has a lower conductivity than helium (almost an order of magnitude less), higher temperatures result. However, the difference is reduced at higher temperatures where thermal radiation dominates as a heat transfer mechanism and the difference between the fill gases resulted in as little as a $2^{\circ} \mathrm{C}$ difference. Although the nitrogen fill gas resulted in temperatures up to $60^{\circ} \mathrm{C}$ higher, the use of nitrogen is still a significant improvement over a vacuum. 
Table 4.1-3. Peak Temperature Difference (Vacuum vs. Helium), 17x17 PWR Assembly

\begin{tabular}{||c||c|c|c|c|}
\hline \multirow{2}{*}{$\begin{array}{c}\text { Basket Wall } \\
\text { Temperature }\end{array}$} & \multicolumn{4}{|c|}{ Assembly Heat Load } \\
\cline { 2 - 5 } & 250 watts & 500 watts & 750 watts & 1000 watts \\
\hline \hline $25^{\circ} \mathrm{C}$ & $40^{\circ} \mathrm{C}$ & $64^{\circ} \mathrm{C}$ & $80^{\circ} \mathrm{C}$ & $92^{\circ} \mathrm{C}$ \\
\hline $50^{\circ} \mathrm{C}$ & $33^{\circ} \mathrm{C}$ & $53^{\circ} \mathrm{C}$ & $68^{\circ} \mathrm{C}$ & $80^{\circ} \mathrm{C}$ \\
\hline $100^{\circ} \mathrm{C}$ & $21^{\circ} \mathrm{C}$ & $37^{\circ} \mathrm{C}$ & $49^{\circ} \mathrm{C}$ & $59^{\circ} \mathrm{C}$ \\
\hline $150^{\circ} \mathrm{C}$ & $14^{\circ} \mathrm{C}$ & $25^{\circ} \mathrm{C}$ & $35^{\circ} \mathrm{C}$ & $43^{\circ} \mathrm{C}$ \\
\hline $200^{\circ} \mathrm{C}$ & $9{ }^{\circ} \mathrm{C}$ & $18^{\circ} \mathrm{C}$ & $24^{\circ} \mathrm{C}$ & $31^{\circ} \mathrm{C}$ \\
\hline $250^{\circ} \mathrm{C}$ & $6^{\circ} \mathrm{C}$ & $12^{\circ} \mathrm{C}$ & $17^{\circ} \mathrm{C}$ & $22^{\circ} \mathrm{C}$ \\
\hline $300^{\circ} \mathrm{C}$ & $4^{\circ} \mathrm{C}$ & $9{ }^{\circ} \mathrm{C}$ & $12^{\circ} \mathrm{C}$ & $16^{\circ} \mathrm{C}$ \\
\hline $350^{\circ} \mathrm{C}$ & $3^{\circ} \mathrm{C}$ & $6^{\circ} \mathrm{C}$ & $9{ }^{\circ} \mathrm{C}$ & $11^{\circ} \mathrm{C}$ \\
\hline $400^{\circ} \mathrm{C}$ & $2{ }^{\circ} \mathrm{C}$ & $4{ }^{\circ} \mathrm{C}$ & $6^{\circ} \mathrm{C}$ & $8{ }^{\circ} \mathrm{C}$ \\
\hline
\end{tabular}

Table 4.1-4. Peak Temperature Difference (Nitrogen vs. Helium), 17x17 PWR Assembly

\begin{tabular}{||c||c|c|c|c||}
\hline \multirow{2}{*}{$\begin{array}{c}\text { Basket Wall } \\
\text { Temperature }\end{array}$} & \multicolumn{4}{|c||}{ Assembly Heat Load } \\
\cline { 2 - 5 } & 250 watts & 500 watts & 750 watts & 1000 watts \\
\hline $255^{\circ} \mathrm{C}$ & $22^{\circ} \mathrm{C}$ & $38^{\circ} \mathrm{C}$ & $51^{\circ} \mathrm{C}$ & $60^{\circ} \mathrm{C}$ \\
\hline $500^{\circ} \mathrm{C}$ & $19^{\circ} \mathrm{C}$ & $33^{\circ} \mathrm{C}$ & $44^{\circ} \mathrm{C}$ & $52^{\circ} \mathrm{C}$ \\
\hline $100^{\circ} \mathrm{C}$ & $13^{\circ} \mathrm{C}$ & $23^{\circ} \mathrm{C}$ & $32^{\circ} \mathrm{C}$ & $39^{\circ} \mathrm{C}$ \\
\hline $150^{\circ} \mathrm{C}$ & $9{ }^{\circ} \mathrm{C}$ & $16^{\circ} \mathrm{C}$ & $23^{\circ} \mathrm{C}$ & $29^{\circ} \mathrm{C}$ \\
\hline $200^{\circ} \mathrm{C}$ & $6^{\circ} \mathrm{C}$ & $12^{\circ} \mathrm{C}$ & $17^{\circ} \mathrm{C}$ & $21^{\circ} \mathrm{C}$ \\
\hline $250^{\circ} \mathrm{C}$ & $4^{\circ} \mathrm{C}$ & $8^{\circ} \mathrm{C}$ & $12^{\circ} \mathrm{C}$ & $15^{\circ} \mathrm{C}$ \\
\hline $300^{\circ} \mathrm{C}$ & $3^{\circ} \mathrm{C}$ & $6^{\circ} \mathrm{C}$ & $9{ }^{\circ} \mathrm{C}$ & $11^{\circ} \mathrm{C}$ \\
\hline $350^{\circ} \mathrm{C}$ & $2{ }^{\circ} \mathrm{C}$ & $4^{\circ} \mathrm{C}$ & $6^{\circ} \mathrm{C}$ & $8{ }^{\circ} \mathrm{C}$ \\
\hline $400^{\circ} \mathrm{C}$ & $2{ }^{\circ} \mathrm{C}$ & $3^{\circ} \mathrm{C}$ & $5^{\circ} \mathrm{C}$ & $6{ }^{\circ} \mathrm{C}$ \\
\hline
\end{tabular}

Table 4.1-5 lists the peak cladding temperature difference between argon fill gas and the reference fill gas of helium for the 17x17 PWR assembly. Since argon has a lower conductivity than helium (an order of magnitude less), higher temperatures result. However, the difference is reduced at higher temperatures where thermal radiation dominates as a heat transfer mechanism and the difference between the fill gases resulted in as little as a $2^{\circ} \mathrm{C}$ difference. Argon gas has somewhat lower conductivity compared to nitrogen (about one third lower) and results in slightly higher 
temperatures compared to the nitrogen fill gas. However, use of the argon fill gas still represents a significant improvement over vacuum and appears to be roughly equivalent to using nitrogen.

Table 4.1-5. Peak Temperature Difference (Argon vs. Helium), 17x17 PWR Assembly

\begin{tabular}{||c||c|c|c|c||}
\hline \multirow{2}{*}{$\begin{array}{c}\text { Basket Wall } \\
\text { Temperature }\end{array}$} & \multicolumn{4}{|c||}{ Assembly Heat Load } \\
\cline { 2 - 5 } & 250 watts & 500 watts & 750 watts & 1000 watts \\
\hline \hline $25^{\circ} \mathrm{C}$ & $26^{\circ} \mathrm{C}$ & $44^{\circ} \mathrm{C}$ & $58^{\circ} \mathrm{C}$ & $68^{\circ} \mathrm{C}$ \\
\hline $50^{\circ} \mathrm{C}$ & $22^{\circ} \mathrm{C}$ & $37^{\circ} \mathrm{C}$ & $50^{\circ} \mathrm{C}$ & $59^{\circ} \mathrm{C}$ \\
\hline $100^{\circ} \mathrm{C}$ & $15^{\circ} \mathrm{C}$ & $26^{\circ} \mathrm{C}$ & $36^{\circ} \mathrm{C}$ & $44^{\circ} \mathrm{C}$ \\
\hline $150^{\circ} \mathrm{C}$ & $10^{\circ} \mathrm{C}$ & $19^{\circ} \mathrm{C}$ & $26^{\circ} \mathrm{C}$ & $32^{\circ} \mathrm{C}$ \\
\hline $200^{\circ} \mathrm{C}$ & $7^{\circ} \mathrm{C}$ & $13^{\circ} \mathrm{C}$ & $19^{\circ} \mathrm{C}$ & $24^{\circ} \mathrm{C}$ \\
\hline $250^{\circ} \mathrm{C}$ & $5^{\circ} \mathrm{C}$ & $9^{\circ} \mathrm{C}$ & $14^{\circ} \mathrm{C}$ & $17^{\circ} \mathrm{C}$ \\
\hline $300^{\circ} \mathrm{C}$ & $4^{\circ} \mathrm{C}$ & $7^{\circ} \mathrm{C}$ & $10^{\circ} \mathrm{C}$ & $13^{\circ} \mathrm{C}$ \\
\hline $350^{\circ} \mathrm{C}$ & $3^{\circ} \mathrm{C}$ & $5^{\circ} \mathrm{C}$ & $7^{\circ} \mathrm{C}$ & $9^{\circ} \mathrm{C}$ \\
\hline $400^{\circ} \mathrm{C}$ & $2{ }^{\circ} \mathrm{C}$ & $4^{\circ} \mathrm{C}$ & $5^{\circ} \mathrm{C}$ & $7^{\circ} \mathrm{C}$ \\
\hline
\end{tabular}

\subsubsection{PWR 15x15 Designs}

For the $15 \times 15$ PWR model, each of the 36 temperature and heat cases were evaluated for the reference fill gas of helium and the alternate fill environments of vacuum, nitrogen, and argon. ${ }^{[48]}$ The peak cladding temperature predictions for the helium fill gas case are summarized in Table 4.16. As expected, the highest cladding temperatures occurred for the high basket temperature and high heat load case.

Temperature profiles within the assembly were reasonable and very similar to the $17 \times 17$ PWR evaluation and demonstrate all of the same trending. Table 4.1-7 illustrates this trending by summarizing the cladding-to-basket wall temperature drops $(\Delta \mathrm{T})$ for each case. Again, there is a strong nonlinear temperature dependence in the temperature drop which would imply a nonlinear temperature dependence for the effective thermal conductivity $\left(k_{e}\right)$ calculated in Section 6 . As expected, the temperature drop increases with increasing heat load. The impact on the determination of effective thermal conductivities are discussed in Section 6.

For an assembly with no fill gas (vacuum), it is expected that peak temperatures would be higher due to removal of conduction through helium as a heat transfer pathway. Table 4.1-8 lists the peak cladding temperatures difference between no fill gas and the reference fill gas of helium for the $15 \times 15$ PWR assembly. Compared to helium, vacuum resulted in up to $85^{\circ} \mathrm{C}$ higher temperatures at low basket temperatures, but the rise was less than $10^{\circ} \mathrm{C}$ at high temperatures. This trend indicates that thermal radiation dominates as a heat transfer mechanism at higher temperatures. 
Table 4.1-6. Peak Cladding Temperatures, 15x15 PWR Assembly with Helium Fill Gas

\begin{tabular}{||c||c|c|c|c||}
\hline \multirow{2}{*}{$\begin{array}{c}\text { Basket Wall } \\
\text { Temperature }\end{array}$} & \multicolumn{4}{|c|}{ Assembly Heat Load } \\
\cline { 2 - 5 } & 250 watts & 500 watts & 750 watts & 1000 watts \\
\hline $25^{\circ} \mathrm{C}$ & $38^{\circ} \mathrm{C}$ & $51^{\circ} \mathrm{C}$ & $63^{\circ} \mathrm{C}$ & $74^{\circ} \mathrm{C}$ \\
\hline $50^{\circ} \mathrm{C}$ & $62^{\circ} \mathrm{C}$ & $74^{\circ} \mathrm{C}$ & $85^{\circ} \mathrm{C}$ & $96^{\circ} \mathrm{C}$ \\
\hline $100^{\circ} \mathrm{C}$ & $110^{\circ} \mathrm{C}$ & $120^{\circ} \mathrm{C}$ & $129^{\circ} \mathrm{C}$ & $139^{\circ} \mathrm{C}$ \\
\hline $150^{\circ} \mathrm{C}$ & $159^{\circ} \mathrm{C}$ & $167^{\circ} \mathrm{C}$ & $175^{\circ} \mathrm{C}$ & $183^{\circ} \mathrm{C}$ \\
\hline $200^{\circ} \mathrm{C}$ & $207^{\circ} \mathrm{C}$ & $214^{\circ} \mathrm{C}$ & $221^{\circ} \mathrm{C}$ & $228^{\circ} \mathrm{C}$ \\
\hline $250^{\circ} \mathrm{C}$ & $256^{\circ} \mathrm{C}$ & $262^{\circ} \mathrm{C}$ & $268^{\circ} \mathrm{C}$ & $274^{\circ} \mathrm{C}$ \\
\hline $300^{\circ} \mathrm{C}$ & $305^{\circ} \mathrm{C}$ & $311^{\circ} \mathrm{C}$ & $316^{\circ} \mathrm{C}$ & $321^{\circ} \mathrm{C}$ \\
\hline $350^{\circ} \mathrm{C}$ & $355^{\circ} \mathrm{C}$ & $359^{\circ} \mathrm{C}$ & $364^{\circ} \mathrm{C}$ & $368^{\circ} \mathrm{C}$ \\
\hline $400^{\circ} \mathrm{C}$ & $404^{\circ} \mathrm{C}$ & $408^{\circ} \mathrm{C}$ & $412^{\circ} \mathrm{C}$ & $416^{\circ} \mathrm{C}$ \\
\hline
\end{tabular}

Table 4.1-7. Cladding-to-Basket Delta T, 15x15 PWR Assembly"with Helium Fill Gas

\begin{tabular}{||c||c|c|c|c||}
\hline \multirow{2}{*}{$\begin{array}{c}\text { Basket Wall } \\
\text { Temperature }\end{array}$} & \multicolumn{4}{|c|}{ Assembly Heat Load } \\
\cline { 2 - 5 } & 250 watts & 500 watts & 750 watts & 1000 watts \\
\hline \hline $25^{\circ} \mathrm{C}$ & $13^{\circ} \mathrm{C}$ & $26^{\circ} \mathrm{C}$ & $38^{\circ} \mathrm{C}$ & $49^{\circ} \mathrm{C}$ \\
\hline $50^{\circ} \mathrm{C}$ & $12^{\circ} \mathrm{C}$ & $24^{\circ} \mathrm{C}$ & $35^{\circ} \mathrm{C}$ & $46^{\circ} \mathrm{C}$ \\
\hline $100^{\circ} \mathrm{C}$ & $10^{\circ} \mathrm{C}$ & $20^{\circ} \mathrm{C}$ & $29^{\circ} \mathrm{C}$ & $39^{\circ} \mathrm{C}$ \\
\hline $150^{\circ} \mathrm{C}$ & $9{ }^{\circ} \mathrm{C}$ & $17^{\circ} \mathrm{C}$ & $25^{\circ} \mathrm{C}$ & $33^{\circ} \mathrm{C}$ \\
\hline $200^{\circ} \mathrm{C}$ & $7{ }^{\circ} \mathrm{C}$ & $14^{\circ} \mathrm{C}$ & $21^{\circ} \mathrm{C}$ & $28^{\circ} \mathrm{C}$ \\
\hline $250^{\circ} \mathrm{C}$ & $6^{\circ} \mathrm{C}$ & $12^{\circ} \mathrm{C}$ & $18^{\circ} \mathrm{C}$ & $24^{\circ} \mathrm{C}$ \\
\hline $300^{\circ} \mathrm{C}$ & $5^{\circ} \mathrm{C}$ & $11^{\circ} \mathrm{C}$ & $16^{\circ} \mathrm{C}$ & $21^{\circ} \mathrm{C}$ \\
\hline $350^{\circ} \mathrm{C}$ & $5^{\circ} \mathrm{C}$ & $9{ }^{\circ} \mathrm{C}$ & $14^{\circ} \mathrm{C}$ & $18^{\circ} \mathrm{C}$ \\
\hline $400^{\circ} \mathrm{C}$ & $4^{\circ} \mathrm{C}$ & $8{ }^{\circ} \mathrm{C}$ & $12^{\circ} \mathrm{C}$ & $16^{\circ} \mathrm{C}$ \\
\hline
\end{tabular}


Spent Nuclear Fuel Effective Thermal Conductivity Report

DI: BBA000000-01717-5705-00010 REV 00

Page 43 of 154

Table 4.1-8. Peak Temperature Difference (Vacuum vs. Helium), 15x15 PWR Assembly

\begin{tabular}{||c||c|c|c|c||}
\hline \hline \multirow{2}{*}{$\begin{array}{c}\text { Basket Wall } \\
\text { Temperature }\end{array}$} & \multicolumn{4}{|c|}{ Assembly Heat Load } \\
\cline { 2 - 5 } & 250 watts & 500 watts & 750 watts & 1000 watts \\
\hline \hline $25^{\circ} \mathrm{C}$ & $36^{\circ} \mathrm{C}$ & $59^{\circ} \mathrm{C}$ & $74^{\circ} \mathrm{C}$ & $85^{\circ} \mathrm{C}$ \\
\hline $50^{\circ} \mathrm{C}$ & $29^{\circ} \mathrm{C}$ & $49^{\circ} \mathrm{C}$ & $63^{\circ} \mathrm{C}$ & $73^{\circ} \mathrm{C}$ \\
\hline $100^{\circ} \mathrm{C}$ & $19^{\circ} \mathrm{C}$ & $33^{\circ} \mathrm{C}$ & $44^{\circ} \mathrm{C}$ & $53^{\circ} \mathrm{C}$ \\
\hline $150^{\circ} \mathrm{C}$ & $12^{\circ} \mathrm{C}$ & $23^{\circ} \mathrm{C}$ & $31^{\circ} \mathrm{C}$ & $38^{\circ} \mathrm{C}$ \\
\hline $200^{\circ} \mathrm{C}$ & $8^{\circ} \mathrm{C}$ & $15^{\circ} \mathrm{C}$ & $22^{\circ} \mathrm{C}$ & $27^{\circ} \mathrm{C}$ \\
\hline $250^{\circ} \mathrm{C}$ & $6^{\circ} \mathrm{C}$ & $11^{\circ} \mathrm{C}$ & $15^{\circ} \mathrm{C}$ & $19^{\circ} \mathrm{C}$ \\
\hline $300^{\circ} \mathrm{C}$ & $4^{\circ} \mathrm{C}$ & $7^{\circ} \mathrm{C}$ & $11^{\circ} \mathrm{C}$ & $14^{\circ} \mathrm{C}$ \\
\hline $350^{\circ} \mathrm{C}$ & $3^{\circ} \mathrm{C}$ & $5^{\circ} \mathrm{C}$ & $8^{\circ} \mathrm{C}$ & $10^{\circ} \mathrm{C}$ \\
\hline $400^{\circ} \mathrm{C}$ & $2{ }^{\circ} \mathrm{C}$ & $4^{\circ} \mathrm{C}$ & $5^{\circ} \mathrm{C}$ & $7^{\circ} \mathrm{C}$ \\
\hline
\end{tabular}

Table 4.1-9 lists the peak cladding temperature difference between nitrogen fill gas and the reference fill gas of helium for the $15 \times 15$ PWR assembly. Since nitrogen has a lower conductivity than helium (almost an order of magnitude less), higher temperatures result. However, the difference is reduced at higher temperatures where thermal radiation dominates as a heat transfer mechanism and the difference between the fill gases resulted in as little as a $1^{\circ} \mathrm{C}$ difference. Although the nitrogen fill gas resulted in temperatures up to $56^{\circ} \mathrm{C}$ higher, the use of nitrogen is still a significant improvement over a vacuum.

Table 4.1-9. Peak Temperature Difference (Nitrogen vs. Helium), 15x15 PWR Assembly

\begin{tabular}{||c||c|c|c|c||}
\hline \multirow{2}{*}{$\begin{array}{c}\text { Basket Wall } \\
\text { Temperature }\end{array}$} & \multicolumn{4}{|c|}{ Assembly Heat Load } \\
\cline { 2 - 5 } & 250 watts & 500 watts & 750 watts & 1000 watts \\
\hline $25^{\circ} \mathrm{C}$ & $21^{\circ} \mathrm{C}$ & $36^{\circ} \mathrm{C}$ & $47^{\circ} \mathrm{C}$ & $56^{\circ} \mathrm{C}$ \\
\hline $50^{\circ} \mathrm{C}$ & $17^{\circ} \mathrm{C}$ & $30^{\circ} \mathrm{C}$ & $40^{\circ} \mathrm{C}$ & $48^{\circ} \mathrm{C}$ \\
\hline $100^{\circ} \mathrm{C}$ & $12^{\circ} \mathrm{C}$ & $21^{\circ} \mathrm{C}$ & $29^{\circ} \mathrm{C}$ & $36^{\circ} \mathrm{C}$ \\
\hline $150^{\circ} \mathrm{C}$ & $8^{\circ} \mathrm{C}$ & $15^{\circ} \mathrm{C}$ & $21^{\circ} \mathrm{C}$ & $26^{\circ} \mathrm{C}$ \\
\hline $200^{\circ} \mathrm{C}$ & $6^{\circ} \mathrm{C}$ & $10^{\circ} \mathrm{C}$ & $15^{\circ} \mathrm{C}$ & $19^{\circ} \mathrm{C}$ \\
\hline $250^{\circ} \mathrm{C}$ & $4^{\circ} \mathrm{C}$ & $7^{\circ} \mathrm{C}$ & $11^{\circ} \mathrm{C}$ & $14^{\circ} \mathrm{C}$ \\
\hline $300^{\circ} \mathrm{C}$ & $3^{\circ} \mathrm{C}$ & $5^{\circ} \mathrm{C}$ & $8^{\circ} \mathrm{C}$ & $10^{\circ} \mathrm{C}$ \\
\hline $350^{\circ} \mathrm{C}$ & $2^{\circ} \mathrm{C}$ & $4^{\circ} \mathrm{C}$ & $6^{\circ} \mathrm{C}$ & $7^{\circ} \mathrm{C}$ \\
\hline $400^{\circ} \mathrm{C}$ & $1{ }^{\circ} \mathrm{C}$ & $3^{\circ} \mathrm{C}$ & $4^{\circ} \mathrm{C}$ & $5^{\circ} \mathrm{C}$ \\
\hline
\end{tabular}


Table 4.1-10 lists the peak cladding temperature difference between argon fill gas and the reference fill gas of helium for the 15x15 PWR assembly. Since argon has a lower conductivity than helium (an order of magnitude less), higher temperatures result. However, the difference is reduced at higher temperatures where thermal radiation dominates as a heat transfer mechanism and the difference between the fill gases resulted in as little as a $2^{\circ} \mathrm{C}$ difference. Argon gas has somewhat lower conductivity compared to nitrogen (about one third lower) and results in slightly higher temperatures compared to the nitrogen fill gas. However, use of the argon fill gas still represents a significant improvement over vacuum and appears to be roughly equivalent to using nitrogen.

Table 4.1-10. Peak Temperature Difference (Argon vs. Helium), 15x15 PWR Assembly

\begin{tabular}{||c||c|c|c|c||}
\hline \multirow{2}{*}{$\begin{array}{c}\text { Basket Wall } \\
\text { Temperature }\end{array}$} & \multicolumn{4}{|c||}{ Assembly Heat Load } \\
\cline { 2 - 5 } & 250 watts & 500 watts & 750 watts & 1000 watts \\
\hline $25^{\circ} \mathrm{C}$ & $24^{\circ} \mathrm{C}$ & $41^{\circ} \mathrm{C}$ & $54^{\circ} \mathrm{C}$ & $64^{\circ} \mathrm{C}$ \\
\hline $50^{\circ} \mathrm{C}$ & $20^{\circ} \mathrm{C}$ & $34^{\circ} \mathrm{C}$ & $46^{\circ} \mathrm{C}$ & $55^{\circ} \mathrm{C}$ \\
\hline $100^{\circ} \mathrm{C}$ & $13^{\circ} \mathrm{C}$ & $24^{\circ} \mathrm{C}$ & $33^{\circ} \mathrm{C}$ & $40^{\circ} \mathrm{C}$ \\
\hline $150^{\circ} \mathrm{C}$ & $9{ }^{\circ} \mathrm{C}$ & $17^{\circ} \mathrm{C}$ & $23^{\circ} \mathrm{C}$ & $29^{\circ} \mathrm{C}$ \\
\hline $200^{\circ} \mathrm{C}$ & $6^{\circ} \mathrm{C}$ & $12^{\circ} \mathrm{C}$ & $17^{\circ} \mathrm{C}$ & $21^{\circ} \mathrm{C}$ \\
\hline $250^{\circ} \mathrm{C}$ & $4^{\circ} \mathrm{C}$ & $8^{\circ} \mathrm{C}$ & $12^{\circ} \mathrm{C}$ & $15^{\circ} \mathrm{C}$ \\
\hline $300^{\circ} \mathrm{C}$ & $3^{\circ} \mathrm{C}$ & $6^{\circ} \mathrm{C}$ & $9^{\circ} \mathrm{C}$ & $11^{\circ} \mathrm{C}$ \\
\hline $350^{\circ} \mathrm{C}$ & $2{ }^{\circ} \mathrm{C}$ & $4^{\circ} \mathrm{C}$ & $6^{\circ} \mathrm{C}$ & $8^{\circ} \mathrm{C}$ \\
\hline $400^{\circ} \mathrm{C}$ & $2^{\circ} \mathrm{C}$ & $3^{\circ} \mathrm{C}$ & $4^{\circ} \mathrm{C}$ & $6^{\circ} \mathrm{C}$ \\
\hline
\end{tabular}

The results of the $15 \times 15$ PWR assembly evaluation are very similar to the $17 \times 17$ PWR assembly evaluation. For the helium fill gas, peak temperatures differed by $2{ }^{\circ} \mathrm{C}$ or less indicating that the $15 \times 15$ array and the $17 \times 17$ array have similar resistance to heat transfer given the same environment and heat loads. The difference is more pronounced, however, when a vacuum environment is considered. Because the $17 \times 17$ array has one more layer of rods around the perimeter, radiation heat transfer from the center of the rod bundle to the basket wall is more difficult and peak temperatures are up to $9^{\circ} \mathrm{C}$ higher in the $17 \times 17$ array. The differences between the $15 \times 15$ and $17 \times 17$ arrays for nitrogen and argon fall between the differences for helium and vacuum. The nitrogen and argon cases depend on thermal radiation more than the helium case such that peak temperatures in the $17 \times 17$ assembly are 1 to $7^{\circ} \mathrm{C}$ higher than the $15 \times 15$ assembly for those gases. 


\subsubsection{PWR 14x14 Designs}

For the 14x14 PWR model, each of the 36 temperature and heat cases were evaluated for the reference fill gas of helium and the alternate fill environments of vacuum, nitrogen, and argon. ${ }^{[48]}$ The peak cladding temperature predictions for the helium fill gas case are summarized in Table 4.111. As expected, the highest cladding temperatures occurred for the high basket temperature and high heat load case.

Temperature profiles within the assembly were reasonable and very similar to the $17 \times 17$ PWR evaluation and demonstrate all of the same trending. Table 4.1-12 illustrates this trending by summarizing the cladding-to-basket wall temperature drops $(\Delta \mathrm{T})$ for each case. Again, there is a strong nonlinear temperature dependence in the temperature drop which would imply a nonlinear temperature dependence for the effective thermal conductivity $\left(k_{e}\right)$ calculated in Section 6 . As expected, the temperature drop increases with increasing heat load. The impact on the determination of effective thermal conductivities are discussed in Section 6.

Table 4.1-11. Peak Cladding Temperatures, 14x14 PWR Assembly with Helium Fill Gas

\begin{tabular}{||c||c|c|c|c||}
\hline \multirow{2}{*}{$\begin{array}{c}\text { Basket Wall } \\
\text { Temperature }\end{array}$} & \multicolumn{4}{|c|}{ Assembly Heat Load } \\
\cline { 2 - 5 } & 250 watts & 500 watts & 750 watts & 1000 watts \\
\hline \hline $25^{\circ} \mathrm{C}$ & $40^{\circ} \mathrm{C}$ & $55^{\circ} \mathrm{C}$ & $69^{\circ} \mathrm{C}$ & $82^{\circ} \mathrm{C}$ \\
\hline $50^{\circ} \mathrm{C}$ & $64^{\circ} \mathrm{C}$ & $77^{\circ} \mathrm{C}$ & $90^{\circ} \mathrm{C}$ & $102^{\circ} \mathrm{C}$ \\
\hline $100^{\circ} \mathrm{C}$ & $112^{\circ} \mathrm{C}$ & $123^{\circ} \mathrm{C}$ & $134^{\circ} \mathrm{C}$ & $144^{\circ} \mathrm{C}$ \\
\hline $150^{\circ} \mathrm{C}$ & $160^{\circ} \mathrm{C}$ & $169^{\circ} \mathrm{C}$ & $178^{\circ} \mathrm{C}$ & $187^{\circ} \mathrm{C}$ \\
\hline $200^{\circ} \mathrm{C}$ & $208^{\circ} \mathrm{C}$ & $216^{\circ} \mathrm{C}$ & $224^{\circ} \mathrm{C}$ & $232^{\circ} \mathrm{C}$ \\
\hline $250^{\circ} \mathrm{C}$ & $257^{\circ} \mathrm{C}$ & $264^{\circ} \mathrm{C}$ & $270^{\circ} \mathrm{C}$ & $277^{\circ} \mathrm{C}$ \\
\hline $300^{\circ} \mathrm{C}$ & $306^{\circ} \mathrm{C}$ & $312^{\circ} \mathrm{C}$ & $317^{\circ} \mathrm{C}$ & $323^{\circ} \mathrm{C}$ \\
\hline $350^{\circ} \mathrm{C}$ & $355^{\circ} \mathrm{C}$ & $360^{\circ} \mathrm{C}$ & $365^{\circ} \mathrm{C}$ & $370^{\circ} \mathrm{C}$ \\
\hline $400^{\circ} \mathrm{C}$ & $404^{\circ} \mathrm{C}$ & $409^{\circ} \mathrm{C}$ & $413^{\circ} \mathrm{C}$ & $417^{\circ} \mathrm{C}$ \\
\hline
\end{tabular}

For an assembly with no fill gas (vacuum), it is expected that peak temperatures would be higher due to removal of conduction through helium as a heat transfer pathway. Table 4.1-13 lists the peak cladding temperature difference between no fill gas and the reference fill gas of helium for the $14 \times 14$ PWR assembly. Compared to helium, vacuum resulted in up to $84^{\circ} \mathrm{C}$ higher temperatures at low basket temperatures, but the rise was less than $10^{\circ} \mathrm{C}$ at high temperatures. Again, this trend indicates that thermal radiation dominates as a heat transfer mechanism at higher temperatures. 
Table 4.1-12. Cladding-to-Basket Delta T, 14x14 PWR Assembly with Helium Fill Gas

\begin{tabular}{||c||c|c|c|c||}
\hline \multirow{2}{*}{$\begin{array}{c}\text { Basket Wall } \\
\text { Temperature }\end{array}$} & \multicolumn{4}{|c|}{ Assembly Heat Load } \\
\cline { 2 - 5 } & 250 watts & 500 watts & 750 watts & 1000 watts \\
\hline $25^{\circ} \mathrm{C}$ & $15^{\circ} \mathrm{C}$ & $30^{\circ} \mathrm{C}$ & $44^{\circ} \mathrm{C}$ & $57^{\circ} \mathrm{C}$ \\
\hline $50^{\circ} \mathrm{C}$ & $14^{\circ} \mathrm{C}$ & $27^{\circ} \mathrm{C}$ & $40^{\circ} \mathrm{C}$ & $52^{\circ} \mathrm{C}$ \\
\hline $100^{\circ} \mathrm{C}$ & $12^{\circ} \mathrm{C}$ & $23^{\circ} \mathrm{C}$ & $34^{\circ} \mathrm{C}$ & $44^{\circ} \mathrm{C}$ \\
\hline $150^{\circ} \mathrm{C}$ & $10^{\circ} \mathrm{C}$ & $19^{\circ} \mathrm{C}$ & $28^{\circ} \mathrm{C}$ & $37^{\circ} \mathrm{C}$ \\
\hline $200^{\circ} \mathrm{C}$ & $8^{\circ} \mathrm{C}$ & $16^{\circ} \mathrm{C}$ & $24^{\circ} \mathrm{C}$ & $32^{\circ} \mathrm{C}$ \\
\hline $250^{\circ} \mathrm{C}$ & $7^{\circ} \mathrm{C}$ & $14^{\circ} \mathrm{C}$ & $20^{\circ} \mathrm{C}$ & $27^{\circ} \mathrm{C}$ \\
\hline $300^{\circ} \mathrm{C}$ & $6^{\circ} \mathrm{C}$ & $12^{\circ} \mathrm{C}$ & $17^{\circ} \mathrm{C}$ & $23^{\circ} \mathrm{C}$ \\
\hline $350^{\circ} \mathrm{C}$ & $5^{\circ} \mathrm{C}$ & $10^{\circ} \mathrm{C}$ & $15^{\circ} \mathrm{C}$ & $20^{\circ} \mathrm{C}$ \\
\hline $400^{\circ} \mathrm{C}$ & $4^{\circ} \mathrm{C}$ & $9{ }^{\circ} \mathrm{C}$ & $13^{\circ} \mathrm{C}$ & $17^{\circ} \mathrm{C}$ \\
\hline
\end{tabular}

Table 4.1-13. Peak Temperature Difference (Vacuum vs. Helium), 14x14 PWR Assembly

\begin{tabular}{||c||c|c|c|c|}
\hline \multirow{2}{*}{$\begin{array}{c}\text { Basket Wall } \\
\text { Temperature }\end{array}$} & \multicolumn{4}{|c|}{ Assembly Heat Load } \\
\cline { 2 - 5 } & 250 watts & 500 watts & 750 watts & 1000 watts \\
\hline \hline $25^{\circ} \mathrm{C}$ & $37^{\circ} \mathrm{C}$ & $59^{\circ} \mathrm{C}$ & $74^{\circ} \mathrm{C}$ & $84^{\circ} \mathrm{C}$ \\
\hline $50^{\circ} \mathrm{C}$ & $30^{\circ} \mathrm{C}$ & $49^{\circ} \mathrm{C}$ & $63^{\circ} \mathrm{C}$ & $73^{\circ} \mathrm{C}$ \\
\hline $100^{\circ} \mathrm{C}$ & $20^{\circ} \mathrm{C}$ & $34^{\circ} \mathrm{C}$ & $45^{\circ} \mathrm{C}$ & $53^{\circ} \mathrm{C}$ \\
\hline $150^{\circ} \mathrm{C}$ & $13^{\circ} \mathrm{C}$ & $23^{\circ} \mathrm{C}$ & $31^{\circ} \mathrm{C}$ & $38^{\circ} \mathrm{C}$ \\
\hline $200^{\circ} \mathrm{C}$ & $9{ }^{\circ} \mathrm{C}$ & $16^{\circ} \mathrm{C}$ & $22^{\circ} \mathrm{C}$ & $27^{\circ} \mathrm{C}$ \\
\hline $250^{\circ} \mathrm{C}$ & $6^{\circ} \mathrm{C}$ & $11^{\circ} \mathrm{C}$ & $16^{\circ} \mathrm{C}$ & $20^{\circ} \mathrm{C}$ \\
\hline $300^{\circ} \mathrm{C}$ & $4{ }^{\circ} \mathrm{C}$ & $8^{\circ} \mathrm{C}$ & $11^{\circ} \mathrm{C}$ & $14^{\circ} \mathrm{C}$ \\
\hline $350^{\circ} \mathrm{C}$ & $3^{\circ} \mathrm{C}$ & $5^{\circ} \mathrm{C}$ & $8^{\circ} \mathrm{C}$ & $10^{\circ} \mathrm{C}$ \\
\hline $400^{\circ} \mathrm{C}$ & $2{ }^{\circ} \mathrm{C}$ & $4{ }^{\circ} \mathrm{C}$ & $6^{\circ} \mathrm{C}$ & $7{ }^{\circ} \mathrm{C}$ \\
\hline & & & & \\
\hline
\end{tabular}

Table 4.1-14 lists the peak cladding temperature difference between nitrogen fill gas and the reference fill gas of helium for the 14x14 PWR assembly. Again, since nitrogen has a lower conductivity than helium (almost an order of magnitude less), higher temperatures result. However, the difference is reduced at higher temperatures where thermal radiation dominates as a heat transfer mechanism and the difference between the fill gases resulted in as little as a $2^{\circ} \mathrm{C}$ difference. 
Table 4.1-14. Peak Temperature Difference (Nitrogen vs. Helium), 14x14 PWR Assembly

\begin{tabular}{||c||c|c|c|c||}
\hline \multirow{2}{*}{$\begin{array}{c}\text { Basket Wall } \\
\text { Temperature }\end{array}$} & \multicolumn{4}{|c|}{ Assembly Heat Load } \\
\cline { 2 - 5 } & 250 watts & 500 watts & 750 watts & 1000 watts \\
\hline $255^{\circ} \mathrm{C}$ & $22^{\circ} \mathrm{C}$ & $37^{\circ} \mathrm{C}$ & $49^{\circ} \mathrm{C}$ & $57^{\circ} \mathrm{C}$ \\
\hline $50^{\circ} \mathrm{C}$ & $18^{\circ} \mathrm{C}$ & $31^{\circ} \mathrm{C}$ & $41^{\circ} \mathrm{C}$ & $49^{\circ} \mathrm{C}$ \\
\hline $100^{\circ} \mathrm{C}$ & $12^{\circ} \mathrm{C}$ & $22^{\circ} \mathrm{C}$ & $30^{\circ} \mathrm{C}$ & $36^{\circ} \mathrm{C}$ \\
\hline $150^{\circ} \mathrm{C}$ & $8^{\circ} \mathrm{C}$ & $15^{\circ} \mathrm{C}$ & $21^{\circ} \mathrm{C}$ & $27^{\circ} \mathrm{C}$ \\
\hline $200^{\circ} \mathrm{C}$ & $6^{\circ} \mathrm{C}$ & $11^{\circ} \mathrm{C}$ & $15^{\circ} \mathrm{C}$ & $19^{\circ} \mathrm{C}$ \\
\hline $250^{\circ} \mathrm{C}$ & $4^{\circ} \mathrm{C}$ & $8^{\circ} \mathrm{C}$ & $11^{\circ} \mathrm{C}$ & $14^{\circ} \mathrm{C}$ \\
\hline $300^{\circ} \mathrm{C}$ & $3^{\circ} \mathrm{C}$ & $5^{\circ} \mathrm{C}$ & $8^{\circ} \mathrm{C}$ & $10^{\circ} \mathrm{C}$ \\
\hline $350^{\circ} \mathrm{C}$ & $2{ }^{\circ} \mathrm{C}$ & $4^{\circ} \mathrm{C}$ & $6^{\circ} \mathrm{C}$ & $7^{\circ} \mathrm{C}$ \\
\hline $400^{\circ} \mathrm{C}$ & $1{ }^{\circ} \mathrm{C}$ & $3^{\circ} \mathrm{C}$ & $4^{\circ} \mathrm{C}$ & $5^{\circ} \mathrm{C}$ \\
\hline
\end{tabular}

Table 4.1-15 lists the peak cladding temperature difference between argon fill gas and the reference fill gas of helium for the 14x14 PWR assembly. Since argon has a lower conductivity than helium, higher temperatures result; however, the difference is reduced at higher temperatures where the difference between the fill gases resulted in as little as a $2^{\circ} \mathrm{C}$ difference.

Table 4.1-15. Peak Temperature Difference (Argon vs. Helium), 14x14 PWR Assembly

\begin{tabular}{||c|c|c|c|c||}
\hline \multirow{2}{*}{$\begin{array}{c}\text { Basket Wall } \\
\text { Temperature }\end{array}$} & \multicolumn{4}{|c|}{ Assembly Heat Load } \\
\cline { 2 - 5 } & 250 watts & 500 watts & 750 watts & 1000 watts \\
\hline \hline $25^{\circ} \mathrm{C}$ & $25^{\circ} \mathrm{C}$ & $42^{\circ} \mathrm{C}$ & $55^{\circ} \mathrm{C}$ & $64^{\circ} \mathrm{C}$ \\
\hline $50^{\circ} \mathrm{C}$ & $21^{\circ} \mathrm{C}$ & $36^{\circ} \mathrm{C}$ & $47^{\circ} \mathrm{C}$ & $56^{\circ} \mathrm{C}$ \\
\hline $100^{\circ} \mathrm{C}$ & $14^{\circ} \mathrm{C}$ & $25^{\circ} \mathrm{C}$ & $34^{\circ} \mathrm{C}$ & $41^{\circ} \mathrm{C}$ \\
\hline $150^{\circ} \mathrm{C}$ & $9{ }^{\circ} \mathrm{C}$ & $17^{\circ} \mathrm{C}$ & $24^{\circ} \mathrm{C}$ & $30^{\circ} \mathrm{C}$ \\
\hline $200^{\circ} \mathrm{C}$ & $7^{\circ} \mathrm{C}$ & $12^{\circ} \mathrm{C}$ & $17^{\circ} \mathrm{C}$ & $22^{\circ} \mathrm{C}$ \\
\hline $250^{\circ} \mathrm{C}$ & $5^{\circ} \mathrm{C}$ & $9^{\circ} \mathrm{C}$ & $12^{\circ} \mathrm{C}$ & $16^{\circ} \mathrm{C}$ \\
\hline $300^{\circ} \mathrm{C}$ & $3^{\circ} \mathrm{C}$ & $6^{\circ} \mathrm{C}$ & $9^{\circ} \mathrm{C}$ & $11^{\circ} \mathrm{C}$ \\
\hline $350^{\circ} \mathrm{C}$ & $2{ }^{\circ} \mathrm{C}$ & $4^{\circ} \mathrm{C}$ & $6^{\circ} \mathrm{C}$ & $8^{\circ} \mathrm{C}$ \\
\hline $400^{\circ} \mathrm{C}$ & $2{ }^{\circ} \mathrm{C}$ & $3^{\circ} \mathrm{C}$ & $5^{\circ} \mathrm{C}$ & $6^{\circ} \mathrm{C}$ \\
\hline
\end{tabular}


The peak temperature results of the $14 \times 14$ PWR assembly evaluation in helium fill gas were slightly higher than those calculated for the $17 \times 17$ PWR assembly evaluation. For the helium fill gas, peak temperatures were $6^{\circ} \mathrm{C}$ or less higher for the $14 \times 14$ array. This difference was reversed for the vacuum cases where the $17 \times 17$ array resulted in up to $2^{\circ} \mathrm{C}$ higher temperatures. Because the $17 \times 17$ array has more layers of rods around the perimeter, radiation heat transfer from the center of the rod bundle to the basket wall is more difficult and peak temperatures are higher, for radiation dominated conditions. For conduction dominated conditions, the $14 \times 14$ array, which has over-sized guide tubes displacing a larger proportion of fuel rods and the shortest length, has a sufficiently higher heat load per fuel rod such that resulting peak temperatures were higher than those for the $17 \times 17$ and $15 \times 15$ arrays. For the fill gases of nitrogen and argon, the $14 \times 14$ array predicted peak temperatures less than $2{ }^{\circ} \mathrm{C}$ higher than the $17 \times 17$ array. However, the trend of slightly higher resultant temperatures in the $14 \times 14$ array does not necessarily translate to lower (more conservative) effective thermal conductivity values for all of the fill environments, as seen in Section 6. 


\subsection{BWR Assembly Geometries}

For each of the discrete BWR assembly models generated in Section 3 (with and without channels and water rods for each array size), a matrix of SNF model solution cases were developed. The results of these cases will be used to determine the temperature and heat load dependence of the effective thermal conductivities calculated in Section 6 . To bound the possible operational range of BWR SNF environments for repository disposal, nine basket temperatures were selected: 25,50 , $100,150,200,250,300,350$, and $400^{\circ} \mathrm{C}$. This range is intended to cover possible waste package basket temperatures from bounding values greater than the SNF cladding limit of $350^{\circ} \mathrm{C}$ to potential repository ambient rock temperatures of about $25^{\circ} \mathrm{C}^{[26]}$ Six BWR SNF heat loads were also selected based on a range of BWR SNF types that could be received at the repository: 100, 200, 300, 400, 500 , and 600 watts. SNF heat loads vary greatly depending on the age (time since discharge from the reactor), burnup, and other assembly design characteristics. For comparison, a BWR design basis $^{[29]}$ of 10 years old and $49 \mathrm{GWd} / \mathrm{MTU}$ burnup generates an initial 409 watts, and an older, but less burned assembly, of 20 years old and $40 \mathrm{GWd} / \mathrm{MTU}$ burnup generates 265 watts. ${ }^{[2]}$

\subsubsection{BWR 9x9 Designs}

For the 9x9 BWR model with an 80 mil channel, each of the 54 temperature and heat cases were evaluated for the reference fill gas of helium and the alternate fill environments of vacuum, nitrogen, and argon. ${ }^{[51]}$ The peak cladding temperature predictions for the helium fill gas case are summarized in Table 4.2-1. As expected, the highest cladding temperatures occurred for the high basket temperature and high heat load case.

Temperature profiles within the assembly were reasonable as demonstrated in Figure 4.2-1 which displays a sample plot of temperature contours for the helium fill gas case with an assembly heat of 300 watts and a basket wall temperature of $250^{\circ} \mathrm{C}$. This case is representative of conditions typical of analyses of MGDS BWR UCF disposal container conceptual designs. In one BWR UCF design analysis, ${ }^{[29]}$ peak basket temperatures were predicted in the range of $242^{\circ} \mathrm{C}$ to $265^{\circ} \mathrm{C}$ and peak cladding temperatures in the range of $267^{\circ} \mathrm{C}$ to $285^{\circ} \mathrm{C}$ (Wooton-Epstein correlation) depending on the repository thermal loading strategy ( 25 to $100 \mathrm{MTU} / \mathrm{acre}$ ). For the reference $83 \mathrm{MTU} / \mathrm{acre}$ repository thermal loading strategy, a peak basket temperature of $256^{\circ} \mathrm{C}$ and a peak cladding temperature of $277^{\circ} \mathrm{C}$ for the UCF disposal container design were reported. These particular conditions correspond closest to the SNF model case with a $250^{\circ} \mathrm{C}$ basket temperature with a heat load of 400 watts. A peak cladding estimate for this case of $265^{\circ} \mathrm{C}$ (see Table 4.2-1) predicted by the base model indicates a more realistic (less conservative) evaluation of temperatures in a BWR SNF assembly with a channel. Peak temperatures would be significantly less in this case if the BWR SNF assembly channel were not modeled or if water rods were present in the assembly; however, the Wooton-Epstein correlation peak cladding predictions would not vary since the correlation does not consider the existence of the BWR channel. Benchmarks against reported experimental SNF thermal tests in Section 7.2 indicate that this BWR SNF model provides a "best estimate" of peak temperatures within an BWR SNF assembly. The impact on the determination of effective thermal conductivities is discussed in Section 6. 
Spent Nuclear Fuel Effective Thermal Conductivity Report

Table 4.2-1. Peak Cladding Temperatures, 9x9 BWR Assembly with Helium Fill Gas

\begin{tabular}{||c||c|c|c|c|c|c||}
\hline \hline \multirow{2}{*}{$\begin{array}{c}\text { Basket Wall } \\
\text { Temperature }\end{array}$} & \multicolumn{5}{|c||}{ Assembly Heat Load } \\
\cline { 2 - 7 } & 100 watts & 200 watts & 300 watts & 400 watts & 500 watts & 600 watts \\
\hline \hline $25^{\circ} \mathrm{C}$ & $33^{\circ} \mathrm{C}$ & $41^{\circ} \mathrm{C}$ & $49^{\circ} \mathrm{C}$ & $57^{\circ} \mathrm{C}$ & $64^{\circ} \mathrm{C}$ & $71^{\circ} \mathrm{C}$ \\
\hline $50^{\circ} \mathrm{C}$ & $58^{\circ} \mathrm{C}$ & $65^{\circ} \mathrm{C}$ & $72^{\circ} \mathrm{C}$ & $79^{\circ} \mathrm{C}$ & $86^{\circ} \mathrm{C}$ & $92^{\circ} \mathrm{C}$ \\
\hline $100^{\circ} \mathrm{C}$ & $106^{\circ} \mathrm{C}$ & $112^{\circ} \mathrm{C}$ & $118^{\circ} \mathrm{C}$ & $124^{\circ} \mathrm{C}$ & $130^{\circ} \mathrm{C}$ & $136^{\circ} \mathrm{C}$ \\
\hline $150^{\circ} \mathrm{C}$ & $155^{\circ} \mathrm{C}$ & $160^{\circ} \mathrm{C}$ & $165^{\circ} \mathrm{C}$ & $171^{\circ} \mathrm{C}$ & $175^{\circ} \mathrm{C}$ & $180^{\circ} \mathrm{C}$ \\
\hline $200^{\circ} \mathrm{C}$ & $204^{\circ} \mathrm{C}$ & $209^{\circ} \mathrm{C}$ & $213^{\circ} \mathrm{C}$ & $217^{\circ} \mathrm{C}$ & $221^{\circ} \mathrm{C}$ & $226^{\circ} \mathrm{C}$ \\
\hline $250^{\circ} \mathrm{C}$ & $254^{\circ} \mathrm{C}$ & $257^{\circ} \mathrm{C}$ & $261^{\circ} \mathrm{C}$ & $265^{\circ} \mathrm{C}$ & $268^{\circ} \mathrm{C}$ & $272^{\circ} \mathrm{C}$ \\
\hline $300^{\circ} \mathrm{C}$ & $303^{\circ} \mathrm{C}$ & $306^{\circ} \mathrm{C}$ & $309^{\circ} \mathrm{C}$ & $313^{\circ} \mathrm{C}$ & $316^{\circ} \mathrm{C}$ & $319^{\circ} \mathrm{C}$ \\
\hline $350^{\circ} \mathrm{C}$ & $353^{\circ} \mathrm{C}$ & $355^{\circ} \mathrm{C}$ & $358^{\circ} \mathrm{C}$ & $361^{\circ} \mathrm{C}$ & $363^{\circ} \mathrm{C}$ & $366^{\circ} \mathrm{C}$ \\
\hline $400^{\circ} \mathrm{C}$ & $402^{\circ} \mathrm{C}$ & $405^{\circ} \mathrm{C}$ & $407^{\circ} \mathrm{C}$ & $409^{\circ} \mathrm{C}$ & $412^{\circ} \mathrm{C}$ & $414^{\circ} \mathrm{C}$ \\
\hline \hline
\end{tabular}

Table 4.2-2. Cladding-to-Basket Delta T, 9x9 BWR Assembly with Helium Fill Gas

\begin{tabular}{||c||c|c|c|c|c|c||}
\hline \hline \multirow{2}{*}{$\begin{array}{c}\text { Basket Wall } \\
\text { Temperature }\end{array}$} & \multicolumn{7}{|c||}{ Assembly Heat Load } \\
\cline { 2 - 7 } & 100 watts & 200 watts & 300 watts & 400 watts & 500 watts & 600 watts \\
\hline \hline $25^{\circ} \mathrm{C}$ & $8{ }^{\circ} \mathrm{C}$ & $16^{\circ} \mathrm{C}$ & $24^{\circ} \mathrm{C}$ & $32^{\circ} \mathrm{C}$ & $39^{\circ} \mathrm{C}$ & $46^{\circ} \mathrm{C}$ \\
\hline $50^{\circ} \mathrm{C}$ & $8{ }^{\circ} \mathrm{C}$ & $15^{\circ} \mathrm{C}$ & $22^{\circ} \mathrm{C}$ & $29^{\circ} \mathrm{C}$ & $36^{\circ} \mathrm{C}$ & $42^{\circ} \mathrm{C}$ \\
\hline $100^{\circ} \mathrm{C}$ & $6^{\circ} \mathrm{C}$ & $12^{\circ} \mathrm{C}$ & $18^{\circ} \mathrm{C}$ & $24^{\circ} \mathrm{C}$ & $30^{\circ} \mathrm{C}$ & $36^{\circ} \mathrm{C}$ \\
\hline $150^{\circ} \mathrm{C}$ & $5^{\circ} \mathrm{C}$ & $10^{\circ} \mathrm{C}$ & $15^{\circ} \mathrm{C}$ & $20^{\circ} \mathrm{C}$ & $25^{\circ} \mathrm{C}$ & $30^{\circ} \mathrm{C}$ \\
\hline $200^{\circ} \mathrm{C}$ & $4^{\circ} \mathrm{C}$ & $9^{\circ} \mathrm{C}$ & $13^{\circ} \mathrm{C}$ & $17^{\circ} \mathrm{C}$ & $21{ }^{\circ} \mathrm{C}$ & $26^{\circ} \mathrm{C}$ \\
\hline $250^{\circ} \mathrm{C}$ & $4^{\circ} \mathrm{C}$ & $77^{\circ} \mathrm{C}$ & $11^{\circ} \mathrm{C}$ & $15^{\circ} \mathrm{C}$ & $18^{\circ} \mathrm{C}$ & $22^{\circ} \mathrm{C}$ \\
\hline $300^{\circ} \mathrm{C}$ & $3^{\circ} \mathrm{C}$ & $6^{\circ} \mathrm{C}$ & $9^{\circ} \mathrm{C}$ & $13^{\circ} \mathrm{C}$ & $16^{\circ} \mathrm{C}$ & $19^{\circ} \mathrm{C}$ \\
\hline $350^{\circ} \mathrm{C}$ & $3^{\circ} \mathrm{C}$ & $5^{\circ} \mathrm{C}$ & $8^{\circ} \mathrm{C}$ & $10^{\circ} \mathrm{C}$ & $13^{\circ} \mathrm{C}$ & $16^{\circ} \mathrm{C}$ \\
\hline $400^{\circ} \mathrm{C}$ & $2{ }^{\circ} \mathrm{C}$ & $5^{\circ} \mathrm{C}$ & $7^{\circ} \mathrm{C}$ & $9{ }^{\circ} \mathrm{C}$ & $12^{\circ} \mathrm{C}$ & $14^{\circ} \mathrm{C}$ \\
\hline
\end{tabular}


Spent Nuclear Fuel Effective Thermal Conductivity Report

DI: BBA000000-01717-5705-00010 REV 00

Page 52 of 154

INTENTIONALLY LEFT BLANK 
The results in Table 4.2-1 are reasonably consistent with the test case results from preliminary calculations for a PWR $15 \times 15$ SNF assembly ${ }^{[38]}$ and demonstrate some of the expected trending (extrapolated to BWR SNF assemblies). Table 4.2-2 illustrates this trending by summarizing the cladding-to-basket wall temperature drops $(\Delta \mathrm{T})$ for each case. Without the contribution of thermal radiation as a heat transfer mechanism, one might expect that the temperature drop would depend on the assembly heat load only (that is, $\mathrm{q}^{\prime \prime}=\mathrm{k} \cdot \Delta \mathrm{T} / \mathrm{L}$ ). However, Table $4.2-2$ shows that there is a strong nonlinear temperature dependence in the temperature drop which would imply a nonlinear effective thermal conductivity $\left(\mathrm{k}_{\mathrm{e}}\right)$ calculated in Section 6 .

Because the radiation heat transfer depends on $T^{4}$ (that is, $q^{\prime \prime}=\epsilon \sigma\left(T_{1}^{4}-T_{2}^{4}\right)$ ), there is less thermal resistance as absolute temperatures increase for a given heat load and, therefore, the temperature drop decreases at higher temperatures. As expected, the temperature drop will increase with increasing heat load. The implication is that to define an effective thermal conductivity $\left(\mathrm{k}_{\mathrm{e}}\right)$, such that $q "=k_{e} \cdot \Delta T / L$, the effective thermal conductivity must be temperature-dependent. Because of the multiple nonlinearities involved in an SNF assembly thermal analysis, there may also be a heat load dependence on $\mathrm{k}_{\mathrm{e}}$ as well. Section 6 investigates the trending in the determination of the SNF effective thermal conductivity.

For an assembly with no fill gas (vacuum), it is expected that peak temperatures would be higher due to removal of conduction through helium as a heat transfer pathway. Table 4.2-3 lists the peak cladding temperature difference between no fill gas and the reference fill gas of helium for the $9 \times 9$ BWR assembly. It should be noted that for the tables in this section that report temperature differences between fill gases and assembly designs, the values reported in the supporting design analyse ${ }^{[49,50,51]}$ attachments (directly from the ANSYS outputs and not the design analysis summary tables) were compared to avoid round-off errors.

With no fill gas in the assembly, radiation is the only heat transfer mechanism and the temperaturedependent effects observed for helium are more pronounced for vacuum. Compared to helium, vacuum resulted in up to $81^{\circ} \mathrm{C}$ higher temperatures at low basket temperatures, but the rise was less than $8^{\circ} \mathrm{C}$ at high temperatures. This trend indicates that thermal radiation dominates as a heat transfer mechanism at higher temperatures for assemblies with fill gases.

Tables 4.2-4 and 4.2-5 summarize the peak cladding difference between the helium fill gas case and fill gases of nitrogen and argon, respectively. Nitrogen is up to $54^{\circ} \mathrm{C}$ hotter and Argon is up to $61^{\circ} \mathrm{C}$ hotter than the helium fill gas. However, the difference is greatly reduced at higher temperatures where thermal radiation dominates. In both cases, the fill gas is a significant improvement over vacuum. 
Spent Nuclear Fuel Effective Thermal Conductivity Report

Table 4.2-3. Peak Temperature Difference (Vacuum vs. Helium), 9x9 BWR Assembly

\begin{tabular}{||c||c|c|c|c|c|c||}
\hline \hline \multirow{2}{*}{$\begin{array}{c}\text { Basket Wall } \\
\text { Temperature }\end{array}$} & \multicolumn{7}{|c||}{ Assembly Heat Load } \\
\cline { 2 - 7 } & 100 watts & 200 watts & 300 watts & 400 watts & 500 watts & 600 watts \\
\hline \hline $25^{\circ} \mathrm{C}$ & $25^{\circ} \mathrm{C}$ & $42^{\circ} \mathrm{C}$ & $55^{\circ} \mathrm{C}$ & $66^{\circ} \mathrm{C}$ & $74^{\circ} \mathrm{C}$ & $81^{\circ} \mathrm{C}$ \\
\hline $50^{\circ} \mathrm{C}$ & $20^{\circ} \mathrm{C}$ & $34^{\circ} \mathrm{C}$ & $46^{\circ} \mathrm{C}$ & $55^{\circ} \mathrm{C}$ & $63^{\circ} \mathrm{C}$ & $70^{\circ} \mathrm{C}$ \\
\hline $100^{\circ} \mathrm{C}$ & $12^{\circ} \mathrm{C}$ & $22^{\circ} \mathrm{C}$ & $31^{\circ} \mathrm{C}$ & $38^{\circ} \mathrm{C}$ & $45^{\circ} \mathrm{C}$ & $50^{\circ} \mathrm{C}$ \\
\hline $150^{\circ} \mathrm{C}$ & $8{ }^{\circ} \mathrm{C}$ & $15^{\circ} \mathrm{C}$ & $21^{\circ} \mathrm{C}$ & $27^{\circ} \mathrm{C}$ & $31^{\circ} \mathrm{C}$ & $36^{\circ} \mathrm{C}$ \\
\hline $200^{\circ} \mathrm{C}$ & $5^{\circ} \mathrm{C}$ & $10^{\circ} \mathrm{C}$ & $14^{\circ} \mathrm{C}$ & $18^{\circ} \mathrm{C}$ & $22^{\circ} \mathrm{C}$ & $25^{\circ} \mathrm{C}$ \\
\hline $250^{\circ} \mathrm{C}$ & $4{ }^{\circ} \mathrm{C}$ & $77^{\circ} \mathrm{C}$ & $10^{\circ} \mathrm{C}$ & $13^{\circ} \mathrm{C}$ & $15^{\circ} \mathrm{C}$ & $18^{\circ} \mathrm{C}$ \\
\hline $300^{\circ} \mathrm{C}$ & $2{ }^{\circ} \mathrm{C}$ & $5^{\circ} \mathrm{C}$ & $7{ }^{\circ} \mathrm{C}$ & $9^{\circ} \mathrm{C}$ & $11^{\circ} \mathrm{C}$ & $13^{\circ} \mathrm{C}$ \\
\hline $350^{\circ} \mathrm{C}$ & $2{ }^{\circ} \mathrm{C}$ & $3^{\circ} \mathrm{C}$ & $5{ }^{\circ} \mathrm{C}$ & $6^{\circ} \mathrm{C}$ & $8^{\circ} \mathrm{C}$ & $9{ }^{\circ} \mathrm{C}$ \\
\hline $400^{\circ} \mathrm{C}$ & $1{ }^{\circ} \mathrm{C}$ & $2{ }^{\circ} \mathrm{C}$ & $3{ }^{\circ} \mathrm{C}$ & $5^{\circ} \mathrm{C}$ & $6{ }^{\circ} \mathrm{C}$ & $7{ }^{\circ} \mathrm{C}$ \\
\hline
\end{tabular}

Table 4.2-4. Peak Temperature Difference (Nitrogen vs. Helium), 9x9 BWR Assembly

\begin{tabular}{||c||c|c|c|c|c|c||}
\hline \hline \multirow{2}{*}{$\begin{array}{c}\text { Basket Wall } \\
\text { Temperature }\end{array}$} & \multicolumn{5}{|c||}{ Assembly Heat Load } \\
\cline { 2 - 7 } & 100 watts & 200 watts & 300 watts & 400 watts & 500 watts & 600 watts \\
\hline \hline $25^{\circ} \mathrm{C}$ & $14^{\circ} \mathrm{C}$ & $25^{\circ} \mathrm{C}$ & $34^{\circ} \mathrm{C}$ & $42^{\circ} \mathrm{C}$ & $48^{\circ} \mathrm{C}$ & $54^{\circ} \mathrm{C}$ \\
\hline $50{ }^{\circ} \mathrm{C}$ & $11^{\circ} \mathrm{C}$ & $21^{\circ} \mathrm{C}$ & $29^{\circ} \mathrm{C}$ & $35^{\circ} \mathrm{C}$ & $41^{\circ} \mathrm{C}$ & $46^{\circ} \mathrm{C}$ \\
\hline $100^{\circ} \mathrm{C}$ & $8{ }^{\circ} \mathrm{C}$ & $14^{\circ} \mathrm{C}$ & $20^{\circ} \mathrm{C}$ & $25^{\circ} \mathrm{C}$ & $30^{\circ} \mathrm{C}$ & $34^{\circ} \mathrm{C}$ \\
\hline $150^{\circ} \mathrm{C}$ & $5^{\circ} \mathrm{C}$ & $10^{\circ} \mathrm{C}$ & $14^{\circ} \mathrm{C}$ & $18^{\circ} \mathrm{C}$ & $21^{\circ} \mathrm{C}$ & $25^{\circ} \mathrm{C}$ \\
\hline $200^{\circ} \mathrm{C}$ & $4^{\circ} \mathrm{C}$ & $77^{\circ} \mathrm{C}$ & $10^{\circ} \mathrm{C}$ & $13^{\circ} \mathrm{C}$ & $15^{\circ} \mathrm{C}$ & $18^{\circ} \mathrm{C}$ \\
\hline $250^{\circ} \mathrm{C}$ & $2{ }^{\circ} \mathrm{C}$ & $5^{\circ} \mathrm{C}$ & $7^{\circ} \mathrm{C}$ & $9^{\circ} \mathrm{C}$ & $11^{\circ} \mathrm{C}$ & $13^{\circ} \mathrm{C}$ \\
\hline $300^{\circ} \mathrm{C}$ & $2{ }^{\circ} \mathrm{C}$ & $3^{\circ} \mathrm{C}$ & $5^{\circ} \mathrm{C}$ & $6^{\circ} \mathrm{C}$ & $8^{\circ} \mathrm{C}$ & $9{ }^{\circ} \mathrm{C}$ \\
\hline $350^{\circ} \mathrm{C}$ & $1{ }^{\circ} \mathrm{C}$ & $2^{\circ} \mathrm{C}$ & $4{ }^{\circ} \mathrm{C}$ & $5^{\circ} \mathrm{C}$ & $6^{\circ} \mathrm{C}$ & $7^{\circ} \mathrm{C}$ \\
\hline $400^{\circ} \mathrm{C}$ & $1{ }^{\circ} \mathrm{C}$ & $2^{\circ} \mathrm{C}$ & $3^{\circ} \mathrm{C}$ & $3^{\circ} \mathrm{C}$ & $4^{\circ} \mathrm{C}$ & $5^{\circ} \mathrm{C}$ \\
\hline
\end{tabular}


Table 4.2-5. Peak Temperature Difference (Argon vs. Helium), 9x9 BWR Assembly

\begin{tabular}{|c|c|c|c|c|c|c|}
\hline \multirow{2}{*}{$\begin{array}{l}\text { Basket Wall } \\
\text { Temperature }\end{array}$} & \multicolumn{6}{|c|}{ Assembly Heat Load } \\
\hline & 100 watts & 200 watts & 300 watts & 400 watts & 500 watts & 600 watts \\
\hline $25^{\circ} \mathrm{C}$ & $16^{\circ} \mathrm{C}$ & $29^{\circ} \mathrm{C}$ & $39^{\circ} \mathrm{C}$ & $48^{\circ} \mathrm{C}$ & $55^{\circ} \mathrm{C}$ & $61^{\circ} \mathrm{C}$ \\
\hline $50^{\circ} \mathrm{C}$ & $13^{\circ} \mathrm{C}$ & $24^{\circ} \mathrm{C}$ & $33^{\circ} \mathrm{C}$ & $40^{\circ} \mathrm{C}$ & $47^{\circ} \mathrm{C}$ & $52^{\circ} \mathrm{C}$ \\
\hline $100^{\circ} \mathrm{C}$ & $9^{\circ} \mathrm{C}$ & $16^{\circ} \mathrm{C}$ & $23^{\circ} \mathrm{C}$ & $28^{\circ} \mathrm{C}$ & $34^{\circ} \mathrm{C}$ & $38^{\circ} \mathrm{C}$ \\
\hline $150^{\circ} \mathrm{C}$ & $6^{\circ} \mathrm{C}$ & $11^{\circ} \mathrm{C}$ & $16^{\circ} \mathrm{C}$ & $20^{\circ} \mathrm{C}$ & $24^{\circ} \mathrm{C}$ & $28^{\circ} \mathrm{C}$ \\
\hline $200^{\circ} \mathrm{C}$ & $4^{\circ} \mathrm{C}$ & $8^{\circ} \mathrm{C}$ & $11^{\circ} \mathrm{C}$ & $14^{\circ} \mathrm{C}$ & $17^{\circ} \mathrm{C}$ & $20^{\circ} \mathrm{C}$ \\
\hline $250^{\circ} \mathrm{C}$ & $3^{\circ} \mathrm{C}$ & $5^{\circ} \mathrm{C}$ & $8^{\circ} \mathrm{C}$ & $10^{\circ} \mathrm{C}$ & $12^{\circ} \mathrm{C}$ & $14^{\circ} \mathrm{C}$ \\
\hline $300^{\circ} \mathrm{C}$ & $2^{\circ} \mathrm{C}$ & $4^{\circ} \mathrm{C}$ & $6^{\circ} \mathrm{C}$ & $7^{\circ} \mathrm{C}$ & $9^{\circ} \mathrm{C}$ & $10^{\circ} \mathrm{C}$ \\
\hline $350^{\circ} \mathrm{C}$ & $1{ }^{\circ} \mathrm{C}$ & $3^{\circ} \mathrm{C}$ & $4^{\circ} \mathrm{C}$ & $5^{\circ} \mathrm{C}$ & $6^{\circ} \mathrm{C}$ & $8^{\circ} \mathrm{C}$ \\
\hline $400^{\circ} \mathrm{C}$ & $1^{\circ} \mathrm{C}$ & $2^{\circ} \mathrm{C}$ & $3^{\circ} \mathrm{C}$ & $4^{\circ} \mathrm{C}$ & $5^{\circ} \mathrm{C}$ & $5^{\circ} \mathrm{C}$ \\
\hline
\end{tabular}

\subsubsection{BWR 8x8 Designs}

For the $8 \times 8$ BWR model with an 80 mil channel, each of the 54 temperature and heat cases were evaluated for the reference fill gas of helium and the alternate fill environments of vacuum, nitrogen, and argon. ${ }^{[50]}$ The peak cladding temperature predictions for the helium fill gas case are summarized in Table 4.2-6. As expected, the highest cladding temperatures occurred for the high basket temperature and high heat load case.

Temperature profiles within the assembly were reasonable and very similar to the $9 \times 9 \mathrm{BWR}$ evaluation and demonstrate all of the same trending. Table 4.2-7 illustrates this trending by summarizing the cladding-to-basket wall temperature drops $(\Delta \mathrm{T})$ for each case. Again, there is a strong nonlinear temperature dependence in the temperature drop which would imply a nonlinear temperature dependence for the effective thermal conductivity $\left(\mathrm{k}_{\mathrm{e}}\right)$ calculated in Section 6 . As expected, the temperature drop increases with increasing heat load. The impact on the determination of effective thermal conductivities are discussed in Section 6. 
Spent Nuclear Fuel Effective Thermal Conductivity Report

DI: BBA000000-01717-5705-00010 REV 00

Page 56 of 154

Table 4.2-6. Peak Cladding Temperatures, 8x8 BWR Assembly with Helium Fill Gas

\begin{tabular}{||c||c|c|c|c|c|c||}
\hline \hline \multirow{2}{*}{$\begin{array}{c}\text { Basket Wall } \\
\text { Temperature }\end{array}$} & \multicolumn{6}{|c||}{ Assembly Heat Load } \\
\cline { 2 - 7 } & 100 watts & 200 watts & 300 watts & 400 watts & 500 watts & 600 watts \\
\hline \hline $25^{\circ} \mathrm{C}$ & $33^{\circ} \mathrm{C}$ & $41^{\circ} \mathrm{C}$ & $49^{\circ} \mathrm{C}$ & $56^{\circ} \mathrm{C}$ & $63^{\circ} \mathrm{C}$ & $70^{\circ} \mathrm{C}$ \\
\hline $50^{\circ} \mathrm{C}$ & $57^{\circ} \mathrm{C}$ & $65^{\circ} \mathrm{C}$ & $71{ }^{\circ} \mathrm{C}$ & $78^{\circ} \mathrm{C}$ & $85^{\circ} \mathrm{C}$ & $91{ }^{\circ} \mathrm{C}$ \\
\hline $100^{\circ} \mathrm{C}$ & $106^{\circ} \mathrm{C}$ & $112^{\circ} \mathrm{C}$ & $118^{\circ} \mathrm{C}$ & $124^{\circ} \mathrm{C}$ & $129^{\circ} \mathrm{C}$ & $135^{\circ} \mathrm{C}$ \\
\hline $150^{\circ} \mathrm{C}$ & $155^{\circ} \mathrm{C}$ & $160^{\circ} \mathrm{C}$ & $165^{\circ} \mathrm{C}$ & $170^{\circ} \mathrm{C}$ & $175^{\circ} \mathrm{C}$ & $180^{\circ} \mathrm{C}$ \\
\hline $200^{\circ} \mathrm{C}$ & $204^{\circ} \mathrm{C}$ & $209^{\circ} \mathrm{C}$ & $213^{\circ} \mathrm{C}$ & $217^{\circ} \mathrm{C}$ & $221^{\circ} \mathrm{C}$ & $225^{\circ} \mathrm{C}$ \\
\hline $250^{\circ} \mathrm{C}$ & $254^{\circ} \mathrm{C}$ & $257^{\circ} \mathrm{C}$ & $261^{\circ} \mathrm{C}$ & $264^{\circ} \mathrm{C}$ & $268^{\circ} \mathrm{C}$ & $271^{\circ} \mathrm{C}$ \\
\hline $300^{\circ} \mathrm{C}$ & $303^{\circ} \mathrm{C}$ & $306^{\circ} \mathrm{C}$ & $309^{\circ} \mathrm{C}$ & $312^{\circ} \mathrm{C}$ & $315^{\circ} \mathrm{C}$ & $318^{\circ} \mathrm{C}$ \\
\hline $350^{\circ} \mathrm{C}$ & $353^{\circ} \mathrm{C}$ & $355^{\circ} \mathrm{C}$ & $358^{\circ} \mathrm{C}$ & $361^{\circ} \mathrm{C}$ & $363^{\circ} \mathrm{C}$ & $366^{\circ} \mathrm{C}$ \\
\hline $400^{\circ} \mathrm{C}$ & $402^{\circ} \mathrm{C}$ & $405^{\circ} \mathrm{C}$ & $407^{\circ} \mathrm{C}$ & $409^{\circ} \mathrm{C}$ & $412^{\circ} \mathrm{C}$ & $414^{\circ} \mathrm{C}$ \\
\hline
\end{tabular}

Table 4.2-7. Cladding-to-Basket Delta T, 8x8 BWR Assembly with Helium Fill Gas

\begin{tabular}{||c||c|c|c|c|c|c||}
\hline \multirow{2}{*}{\begin{tabular}{|} 
Basket Wall \\
Temperature
\end{tabular}} & \multicolumn{6}{|c||}{ Assembly Heat Load } \\
\cline { 2 - 7 } & 100 watts & 200 watts & 300 watts & 400 watts & 500 watts & 600 watts \\
\hline \hline $25^{\circ} \mathrm{C}$ & $8{ }^{\circ} \mathrm{C}$ & $16^{\circ} \mathrm{C}$ & $24^{\circ} \mathrm{C}$ & $31^{\circ} \mathrm{C}$ & $38^{\circ} \mathrm{C}$ & $45^{\circ} \mathrm{C}$ \\
\hline $50^{\circ} \mathrm{C}$ & $7{ }^{\circ} \mathrm{C}$ & $15^{\circ} \mathrm{C}$ & $21^{\circ} \mathrm{C}$ & $28^{\circ} \mathrm{C}$ & $35^{\circ} \mathrm{C}$ & $41^{\circ} \mathrm{C}$ \\
\hline $100^{\circ} \mathrm{C}$ & $6{ }^{\circ} \mathrm{C}$ & $12^{\circ} \mathrm{C}$ & $18^{\circ} \mathrm{C}$ & $24^{\circ} \mathrm{C}$ & $29^{\circ} \mathrm{C}$ & $35^{\circ} \mathrm{C}$ \\
\hline $150^{\circ} \mathrm{C}$ & $5^{\circ} \mathrm{C}$ & $10^{\circ} \mathrm{C}$ & $15^{\circ} \mathrm{C}$ & $20^{\circ} \mathrm{C}$ & $25^{\circ} \mathrm{C}$ & $30^{\circ} \mathrm{C}$ \\
\hline $200^{\circ} \mathrm{C}$ & $4^{\circ} \mathrm{C}$ & $9{ }^{\circ} \mathrm{C}$ & $13^{\circ} \mathrm{C}$ & $17^{\circ} \mathrm{C}$ & $21^{\circ} \mathrm{C}$ & $25^{\circ} \mathrm{C}$ \\
\hline $250^{\circ} \mathrm{C}$ & $4^{\circ} \mathrm{C}$ & $77^{\circ} \mathrm{C}$ & $11^{\circ} \mathrm{C}$ & $14^{\circ} \mathrm{C}$ & $18^{\circ} \mathrm{C}$ & $21^{\circ} \mathrm{C}$ \\
\hline $300^{\circ} \mathrm{C}$ & $3^{\circ} \mathrm{C}$ & $6^{\circ} \mathrm{C}$ & $9{ }^{\circ} \mathrm{C}$ & $12^{\circ} \mathrm{C}$ & $15^{\circ} \mathrm{C}$ & $18^{\circ} \mathrm{C}$ \\
\hline $350^{\circ} \mathrm{C}$ & $3^{\circ} \mathrm{C}$ & $5^{\circ} \mathrm{C}$ & $8^{\circ} \mathrm{C}$ & $11^{\circ} \mathrm{C}$ & $13^{\circ} \mathrm{C}$ & $16^{\circ} \mathrm{C}$ \\
\hline $400^{\circ} \mathrm{C}$ & $2{ }^{\circ} \mathrm{C}$ & $5^{\circ} \mathrm{C}$ & $7^{\circ} \mathrm{C}$ & $9{ }^{\circ} \mathrm{C}$ & $12^{\circ} \mathrm{C}$ & $14^{\circ} \mathrm{C}$ \\
\hline
\end{tabular}

For an assembly with no fill gas (vacuum), it is expected that peak temperatures would be higher due to removal of conduction through helium as a heat transfer pathway. Table 4.2-8 lists the peak cladding temperatures difference between no fill gas and the reference fill gas of helium for the $8 \times 8$ BWR assembly. Compared to helium, vacuum resulted in up to $80^{\circ} \mathrm{C}$ higher temperatures at low basket temperatures, but the rise was less than $8^{\circ} \mathrm{C}$ at high temperatures. This trend indicates that thermal radiation dominates as a heat transfer mechanism at higher temperatures. 
Table 4.2-8. Peak Temperature Difference (Vacuum vs. Helium), 8x8 BWR Assembly

\begin{tabular}{||c||c|c|c|c|c|c||}
\hline \hline \multirow{2}{*}{$\begin{array}{c}\text { Basket Wall } \\
\text { Temperature }\end{array}$} & \multicolumn{7}{|c||}{ Assembly Heat Load } \\
\cline { 2 - 7 } & 100 watts & 200 watts & 300 watts & 400 watts & 500 watts & 600 watts \\
\hline \hline $25^{\circ} \mathrm{C}$ & $24^{\circ} \mathrm{C}$ & $41^{\circ} \mathrm{C}$ & $54^{\circ} \mathrm{C}$ & $65^{\circ} \mathrm{C}$ & $73^{\circ} \mathrm{C}$ & $80^{\circ} \mathrm{C}$ \\
\hline $50^{\circ} \mathrm{C}$ & $19^{\circ} \mathrm{C}$ & $33^{\circ} \mathrm{C}$ & $45^{\circ} \mathrm{C}$ & $54^{\circ} \mathrm{C}$ & $62^{\circ} \mathrm{C}$ & $69^{\circ} \mathrm{C}$ \\
\hline $100^{\circ} \mathrm{C}$ & $12^{\circ} \mathrm{C}$ & $22^{\circ} \mathrm{C}$ & $30^{\circ} \mathrm{C}$ & $38^{\circ} \mathrm{C}$ & $44^{\circ} \mathrm{C}$ & $50^{\circ} \mathrm{C}$ \\
\hline $150^{\circ} \mathrm{C}$ & $8^{\circ} \mathrm{C}$ & $15^{\circ} \mathrm{C}$ & $21{ }^{\circ} \mathrm{C}$ & $26^{\circ} \mathrm{C}$ & $31^{\circ} \mathrm{C}$ & $35^{\circ} \mathrm{C}$ \\
\hline $200^{\circ} \mathrm{C}$ & $5^{\circ} \mathrm{C}$ & $10^{\circ} \mathrm{C}$ & $14^{\circ} \mathrm{C}$ & $18^{\circ} \mathrm{C}$ & $22^{\circ} \mathrm{C}$ & $25^{\circ} \mathrm{C}$ \\
\hline $250^{\circ} \mathrm{C}$ & $3^{\circ} \mathrm{C}$ & $7^{\circ} \mathrm{C}$ & $10^{\circ} \mathrm{C}$ & $13^{\circ} \mathrm{C}$ & $15^{\circ} \mathrm{C}$ & $18^{\circ} \mathrm{C}$ \\
\hline $300^{\circ} \mathrm{C}$ & $2^{\circ} \mathrm{C}$ & $5^{\circ} \mathrm{C}$ & $7^{\circ} \mathrm{C}$ & $9^{\circ} \mathrm{C}$ & $11^{\circ} \mathrm{C}$ & $13^{\circ} \mathrm{C}$ \\
\hline $350^{\circ} \mathrm{C}$ & $2{ }^{\circ} \mathrm{C}$ & $3^{\circ} \mathrm{C}$ & $5^{\circ} \mathrm{C}$ & $6^{\circ} \mathrm{C}$ & $8^{\circ} \mathrm{C}$ & $9^{\circ} \mathrm{C}$ \\
\hline $400^{\circ} \mathrm{C}$ & $1{ }^{\circ} \mathrm{C}$ & $2{ }^{\circ} \mathrm{C}$ & $3^{\circ} \mathrm{C}$ & $5^{\circ} \mathrm{C}$ & $6^{\circ} \mathrm{C}$ & $7^{\circ} \mathrm{C}$ \\
\hline \hline
\end{tabular}

Tables 4.2-9 and 4.2-10 summarize the peak cladding difference between the helium fill gas case and fill gases of nitrogen and argon, respectively, for the $8 \times 8$ array. Nitrogen is up to $53^{\circ} \mathrm{C}$ hotter and argon is up to $60^{\circ} \mathrm{C}$ hotter than the helium fill gas. However, the difference is greatly reduced at higher temperatures where thermal radiation dominates. In both cases, the fill gas is a significant improvement over vacuum.

Table 4.2-9. Peak Temperature Difference (Nitrogen vs. Helium), 8x8 BWR Assembly

\begin{tabular}{||c||c|c|c|c|c|c||}
\hline \multirow{2}{*}{$\begin{array}{c}\text { Basket Wall } \\
\text { Temperature }\end{array}$} & \multicolumn{7}{|c||}{ Assembly Heat Load } \\
\cline { 2 - 7 } & 100 watts & 200 watts & 300 watts & 400 watts & 500 watts & 600 watts \\
\hline \hline $25^{\circ} \mathrm{C}$ & $13^{\circ} \mathrm{C}$ & $24^{\circ} \mathrm{C}$ & $33^{\circ} \mathrm{C}$ & $40^{\circ} \mathrm{C}$ & $47^{\circ} \mathrm{C}$ & $53^{\circ} \mathrm{C}$ \\
\hline $500^{\circ} \mathrm{C}$ & $11^{\circ} \mathrm{C}$ & $20^{\circ} \mathrm{C}$ & $28^{\circ} \mathrm{C}$ & $34^{\circ} \mathrm{C}$ & $40^{\circ} \mathrm{C}$ & $45^{\circ} \mathrm{C}$ \\
\hline $100^{\circ} \mathrm{C}$ & $7{ }^{\circ} \mathrm{C}$ & $14^{\circ} \mathrm{C}$ & $19^{\circ} \mathrm{C}$ & $24^{\circ} \mathrm{C}$ & $29^{\circ} \mathrm{C}$ & $33^{\circ} \mathrm{C}$ \\
\hline $150^{\circ} \mathrm{C}$ & $5^{\circ} \mathrm{C}$ & $9{ }^{\circ} \mathrm{C}$ & $13^{\circ} \mathrm{C}$ & $17^{\circ} \mathrm{C}$ & $21^{\circ} \mathrm{C}$ & $24^{\circ} \mathrm{C}$ \\
\hline $200^{\circ} \mathrm{C}$ & $3^{\circ} \mathrm{C}$ & $7^{\circ} \mathrm{C}$ & $10^{\circ} \mathrm{C}$ & $12^{\circ} \mathrm{C}$ & $15^{\circ} \mathrm{C}$ & $17^{\circ} \mathrm{C}$ \\
\hline $250^{\circ} \mathrm{C}$ & $2{ }^{\circ} \mathrm{C}$ & $5^{\circ} \mathrm{C}$ & $7^{\circ} \mathrm{C}$ & $9^{\circ} \mathrm{C}$ & $11^{\circ} \mathrm{C}$ & $13^{\circ} \mathrm{C}$ \\
\hline $300^{\circ} \mathrm{C}$ & $2{ }^{\circ} \mathrm{C}$ & $3^{\circ} \mathrm{C}$ & $5^{\circ} \mathrm{C}$ & $6^{\circ} \mathrm{C}$ & $8^{\circ} \mathrm{C}$ & $9^{\circ} \mathrm{C}$ \\
\hline $350^{\circ} \mathrm{C}$ & $1^{\circ} \mathrm{C}$ & $2^{\circ} \mathrm{C}$ & $4^{\circ} \mathrm{C}$ & $5^{\circ} \mathrm{C}$ & $6^{\circ} \mathrm{C}$ & $7^{\circ} \mathrm{C}$ \\
\hline $400^{\circ} \mathrm{C}$ & $1{ }^{\circ} \mathrm{C}$ & $2{ }^{\circ} \mathrm{C}$ & $3^{\circ} \mathrm{C}$ & $3^{\circ} \mathrm{C}$ & $4^{\circ} \mathrm{C}$ & $5^{\circ} \mathrm{C}$ \\
\hline
\end{tabular}


Table 4.2-10. Peak Temperature Difference (Argon vs. Helium), 8x8 BWR Assembly

\begin{tabular}{||c||c|c|c|c|c|c||}
\hline \multirow{2}{*}{$\begin{array}{c}\text { Basket Wall } \\
\text { Temperature }\end{array}$} & \multicolumn{7}{|c||}{ Assembly Heat Load } \\
\cline { 2 - 7 } & 100 watts & 200 watts & 300 watts & 400 watts & 500 watts & 600 watts \\
\hline \hline $25^{\circ} \mathrm{C}$ & $16^{\circ} \mathrm{C}$ & $28^{\circ} \mathrm{C}$ & $38^{\circ} \mathrm{C}$ & $46^{\circ} \mathrm{C}$ & $53^{\circ} \mathrm{C}$ & $60^{\circ} \mathrm{C}$ \\
\hline $50^{\circ} \mathrm{C}$ & $13^{\circ} \mathrm{C}$ & $23^{\circ} \mathrm{C}$ & $32^{\circ} \mathrm{C}$ & $39^{\circ} \mathrm{C}$ & $45^{\circ} \mathrm{C}$ & $51^{\circ} \mathrm{C}$ \\
\hline $100^{\circ} \mathrm{C}$ & $8^{\circ} \mathrm{C}$ & $16^{\circ} \mathrm{C}$ & $22^{\circ} \mathrm{C}$ & $28^{\circ} \mathrm{C}$ & $33^{\circ} \mathrm{C}$ & $37^{\circ} \mathrm{C}$ \\
\hline $150^{\circ} \mathrm{C}$ & $6^{\circ} \mathrm{C}$ & $11^{\circ} \mathrm{C}$ & $15^{\circ} \mathrm{C}$ & $20^{\circ} \mathrm{C}$ & $23^{\circ} \mathrm{C}$ & $27^{\circ} \mathrm{C}$ \\
\hline $200^{\circ} \mathrm{C}$ & $4^{\circ} \mathrm{C}$ & $7^{\circ} \mathrm{C}$ & $11^{\circ} \mathrm{C}$ & $14^{\circ} \mathrm{C}$ & $17^{\circ} \mathrm{C}$ & $19^{\circ} \mathrm{C}$ \\
\hline $250^{\circ} \mathrm{C}$ & $3^{\circ} \mathrm{C}$ & $5^{\circ} \mathrm{C}$ & $8^{\circ} \mathrm{C}$ & $10^{\circ} \mathrm{C}$ & $12^{\circ} \mathrm{C}$ & $14^{\circ} \mathrm{C}$ \\
\hline $300^{\circ} \mathrm{C}$ & $2{ }^{\circ} \mathrm{C}$ & $4^{\circ} \mathrm{C}$ & $5^{\circ} \mathrm{C}$ & $7^{\circ} \mathrm{C}$ & $9^{\circ} \mathrm{C}$ & $10^{\circ} \mathrm{C}$ \\
\hline $350^{\circ} \mathrm{C}$ & $1{ }^{\circ} \mathrm{C}$ & $3^{\circ} \mathrm{C}$ & $4^{\circ} \mathrm{C}$ & $5^{\circ} \mathrm{C}$ & $6^{\circ} \mathrm{C}$ & $7{ }^{\circ} \mathrm{C}$ \\
\hline $400^{\circ} \mathrm{C}$ & $1{ }^{\circ} \mathrm{C}$ & $2{ }^{\circ} \mathrm{C}$ & $3^{\circ} \mathrm{C}$ & $4^{\circ} \mathrm{C}$ & $5^{\circ} \mathrm{C}$ & $5^{\circ} \mathrm{C}$ \\
\hline \hline
\end{tabular}

The results of the $8 \times 8$ BWR assembly are nearly identical to the results for the $9 \times 9$ array. For the helium fill gas, peak temperatures differed by $1{ }^{\circ} \mathrm{C}$ or less indicating that the two assemblies, both with channels, have nearly identical heat transfer characteristics. This same difference was roughly true for the other three fill environments as well. The trending indicates that the presence of the channel around the assembly reduced the thermal radiation differences that would have occurred had the channel been absent. A discussion of the effects of the BWR assembly channel is provided in Section 4.2.4.

\subsubsection{BWR 7x7 Designs}

For the $7 \times 7$ BWR model with an 80 mil channel, each of the 54 temperature and heat cases were evaluated for the reference fill gas of helium and the alternate fill environments of vacuum, nitrogen, and argon ${ }^{[49]}$ The peak cladding temperature predictions for the base model are summarized in Table 4.2-11. As expected, the highest cladding temperatures occurred for the high basket temperature and high heat load case.

Temperature profiles within the assembly were reasonable and very similar to the 9x9 BWR evaluation and demonstrate all of the same trending. Table 4.2-12 illustrates this trending by summarizing the cladding-to-basket wall temperature drops $(\Delta \mathrm{T})$ for each case. Again, there is a strong nonlinear temperature dependence in the temperature drop which would imply a nonlinear temperature dependence for the effective thermal conductivity $\left(\mathrm{k}_{\mathrm{e}}\right)$ calculated in Section 6. As expected, the temperature drop increases with increasing heat load. The impact on the determination of effective thermal conductivities are discussed in Section 6. 
Spent Nuclear Fuel Effective Thermal Conductivity Report

Table 4.2-11. Peak Cladding Temperatures, 7x7 BWR Assembly with Helium Fill Gas

\begin{tabular}{||c||c|c|c|c|c|c||}
\hline \multirow{2}{*}{$\begin{array}{c}\text { Basket Wall } \\
\text { Temperature }\end{array}$} & \multicolumn{6}{|c||}{ Assembly Heat Load } \\
\cline { 2 - 7 } & 100 watts & 200 watts & 300 watts & 400 watts & 500 watts & 600 watts \\
\hline \hline $25^{\circ} \mathrm{C}$ & $33^{\circ} \mathrm{C}$ & $41^{\circ} \mathrm{C}$ & $49^{\circ} \mathrm{C}$ & $56^{\circ} \mathrm{C}$ & $63^{\circ} \mathrm{C}$ & $70^{\circ} \mathrm{C}$ \\
\hline $500^{\circ} \mathrm{C}$ & $57^{\circ} \mathrm{C}$ & $64^{\circ} \mathrm{C}$ & $71^{\circ} \mathrm{C}$ & $78^{\circ} \mathrm{C}$ & $85^{\circ} \mathrm{C}$ & $91{ }^{\circ} \mathrm{C}$ \\
\hline $100^{\circ} \mathrm{C}$ & $106^{\circ} \mathrm{C}$ & $112^{\circ} \mathrm{C}$ & $118^{\circ} \mathrm{C}$ & $124^{\circ} \mathrm{C}$ & $129^{\circ} \mathrm{C}$ & $135^{\circ} \mathrm{C}$ \\
\hline $150^{\circ} \mathrm{C}$ & $155^{\circ} \mathrm{C}$ & $160^{\circ} \mathrm{C}$ & $165^{\circ} \mathrm{C}$ & $170^{\circ} \mathrm{C}$ & $174^{\circ} \mathrm{C}$ & $179^{\circ} \mathrm{C}$ \\
\hline $200^{\circ} \mathrm{C}$ & $204^{\circ} \mathrm{C}$ & $208^{\circ} \mathrm{C}$ & $213^{\circ} \mathrm{C}$ & $217^{\circ} \mathrm{C}$ & $221^{\circ} \mathrm{C}$ & $225^{\circ} \mathrm{C}$ \\
\hline $250^{\circ} \mathrm{C}$ & $254^{\circ} \mathrm{C}$ & $257^{\circ} \mathrm{C}$ & $261^{\circ} \mathrm{C}$ & $264^{\circ} \mathrm{C}$ & $267^{\circ} \mathrm{C}$ & $271^{\circ} \mathrm{C}$ \\
\hline $300^{\circ} \mathrm{C}$ & $303^{\circ} \mathrm{C}$ & $306^{\circ} \mathrm{C}$ & $309^{\circ} \mathrm{C}$ & $312^{\circ} \mathrm{C}$ & $315^{\circ} \mathrm{C}$ & $318^{\circ} \mathrm{C}$ \\
\hline $350^{\circ} \mathrm{C}$ & $353^{\circ} \mathrm{C}$ & $355^{\circ} \mathrm{C}$ & $358^{\circ} \mathrm{C}$ & $360^{\circ} \mathrm{C}$ & $363^{\circ} \mathrm{C}$ & $365^{\circ} \mathrm{C}$ \\
\hline $400^{\circ} \mathrm{C}$ & $402^{\circ} \mathrm{C}$ & $404^{\circ} \mathrm{C}$ & $407^{\circ} \mathrm{C}$ & $409^{\circ} \mathrm{C}$ & $411^{\circ} \mathrm{C}$ & $413^{\circ} \mathrm{C}$ \\
\hline
\end{tabular}

Table 4.2-12. Cladding-to-Basket Delta T, 7x7 BWR Assembly with Helium Fill Gas

\begin{tabular}{|c|c|c|c|c|c|c|}
\hline \multirow{2}{*}{$\begin{array}{l}\text { Basket Wall } \\
\text { Temperature }\end{array}$} & \multicolumn{6}{|c|}{ Assembly Heat Load } \\
\hline & 100 watts & 200 watts & 300 watts & 400 watts & 500 watts & 600 watts \\
\hline $25^{\circ} \mathrm{C}$ & $8^{\circ} \mathrm{C}$ & $16^{\circ} \mathrm{C}$ & $24^{\circ} \mathrm{C}$ & $31^{\circ} \mathrm{C}$ & $38^{\circ} \mathrm{C}$ & $45^{\circ} \mathrm{C}$ \\
\hline $50^{\circ} \mathrm{C}$ & $7^{\circ} \mathrm{C}$ & $14^{\circ} \mathrm{C}$ & $21^{\circ} \mathrm{C}$ & $28^{\circ} \mathrm{C}$ & $35^{\circ} \mathrm{C}$ & $41^{\circ} \mathrm{C}$ \\
\hline $100^{\circ} \mathrm{C}$ & $6^{\circ} \mathrm{C}$ & $12^{\circ} \mathrm{C}$ & $18^{\circ} \mathrm{C}$ & $24^{\circ} \mathrm{C}$ & $29^{\circ} \mathrm{C}$ & $35^{\circ} \mathrm{C}$ \\
\hline $150^{\circ} \mathrm{C}$ & $5^{\circ} \mathrm{C}$ & $10^{\circ} \mathrm{C}$ & $15^{\circ} \mathrm{C}$ & $20^{\circ} \mathrm{C}$ & $24^{\circ} \mathrm{C}$ & $29^{\circ} \mathrm{C}$ \\
\hline $200^{\circ} \mathrm{C}$ & $4^{\circ} \mathrm{C}$ & $8^{\circ} \mathrm{C}$ & $13^{\circ} \mathrm{C}$ & $17^{\circ} \mathrm{C}$ & $21^{\circ} \mathrm{C}$ & $25^{\circ} \mathrm{C}$ \\
\hline $250^{\circ} \mathrm{C}$ & $4^{\circ} \mathrm{C}$ & $7^{\circ} \mathrm{C}$ & $11^{\circ} \mathrm{C}$ & $14^{\circ} \mathrm{C}$ & $17^{\circ} \mathrm{C}$ & $21^{\circ} \mathrm{C}$ \\
\hline $300^{\circ} \mathrm{C}$ & $3^{\circ} \mathrm{C}$ & $6^{\circ} \mathrm{C}$ & $9^{\circ} \mathrm{C}$ & $12^{\circ} \mathrm{C}$ & $15^{\circ} \mathrm{C}$ & $18^{\circ} \mathrm{C}$ \\
\hline $350^{\circ} \mathrm{C}$ & $3^{\circ} \mathrm{C}$ & $5^{\circ} \mathrm{C}$ & $8^{\circ} \mathrm{C}$ & $10^{\circ} \mathrm{C}$ & $13^{\circ} \mathrm{C}$ & $15^{\circ} \mathrm{C}$ \\
\hline $400^{\circ} \mathrm{C}$ & $2^{\circ} \mathrm{C}$ & $4^{\circ} \mathrm{C}$ & $7^{\circ} \mathrm{C}$ & $9^{\circ} \mathrm{C}$ & $11^{\circ} \mathrm{C}$ & $13^{\circ} \mathrm{C}$ \\
\hline
\end{tabular}

For an assembly with no fill gas (vacuum), it is expected that peak temperatures would be higher due to removal of conduction through helium as a heat transfer pathway. Table 4.2-13 lists the peak cladding temperature difference between no fill gas and the reference fill gas of helium for the $7 \times 7$ BWR assembly. Compared to helium, vacuum resulted in up to $73^{\circ} \mathrm{C}$ higher temperatures at low basket temperatures, but the rise was less than $6^{\circ} \mathrm{C}$ at high temperatures. Again, this trend indicates that thermal radiation dominates as a heat transfer mechanism at higher temperatures. 
Table 4.2-13. Peak Temperature Difference (Vacuum vs. Helium), 7x7 BWR Assembly

\begin{tabular}{||c||c|c|c|c|c|c||}
\hline \hline \multirow{2}{*}{$\begin{array}{c}\text { Basket Wall } \\
\text { Temperature }\end{array}$} & \multicolumn{7}{|c||}{ Assembly Heat Load } \\
\cline { 2 - 7 } & 100 watts & 200 watts & 300 watts & 400 watts & 500 watts & 600 watts \\
\hline \hline $25^{\circ} \mathrm{C}$ & $22^{\circ} \mathrm{C}$ & $37^{\circ} \mathrm{C}$ & $49^{\circ} \mathrm{C}$ & $58^{\circ} \mathrm{C}$ & $66^{\circ} \mathrm{C}$ & $73^{\circ} \mathrm{C}$ \\
\hline $50^{\circ} \mathrm{C}$ & $17^{\circ} \mathrm{C}$ & $30^{\circ} \mathrm{C}$ & $40^{\circ} \mathrm{C}$ & $49^{\circ} \mathrm{C}$ & $56^{\circ} \mathrm{C}$ & $62^{\circ} \mathrm{C}$ \\
\hline $100^{\circ} \mathrm{C}$ & $10^{\circ} \mathrm{C}$ & $19^{\circ} \mathrm{C}$ & $27^{\circ} \mathrm{C}$ & $33^{\circ} \mathrm{C}$ & $39^{\circ} \mathrm{C}$ & $44^{\circ} \mathrm{C}$ \\
\hline $150^{\circ} \mathrm{C}$ & $7{ }^{\circ} \mathrm{C}$ & $13^{\circ} \mathrm{C}$ & $18^{\circ} \mathrm{C}$ & $23^{\circ} \mathrm{C}$ & $27^{\circ} \mathrm{C}$ & $31^{\circ} \mathrm{C}$ \\
\hline $200^{\circ} \mathrm{C}$ & $4^{\circ} \mathrm{C}$ & $8^{\circ} \mathrm{C}$ & $12^{\circ} \mathrm{C}$ & $15^{\circ} \mathrm{C}$ & $19^{\circ} \mathrm{C}$ & $22^{\circ} \mathrm{C}$ \\
\hline $250^{\circ} \mathrm{C}$ & $3^{\circ} \mathrm{C}$ & $6^{\circ} \mathrm{C}$ & $8^{\circ} \mathrm{C}$ & $11^{\circ} \mathrm{C}$ & $13^{\circ} \mathrm{C}$ & $15^{\circ} \mathrm{C}$ \\
\hline $300^{\circ} \mathrm{C}$ & $2{ }^{\circ} \mathrm{C}$ & $4^{\circ} \mathrm{C}$ & $6^{\circ} \mathrm{C}$ & $7^{\circ} \mathrm{C}$ & $9^{\circ} \mathrm{C}$ & $11^{\circ} \mathrm{C}$ \\
\hline $350^{\circ} \mathrm{C}$ & $1{ }^{\circ} \mathrm{C}$ & $3^{\circ} \mathrm{C}$ & $4^{\circ} \mathrm{C}$ & $5^{\circ} \mathrm{C}$ & $6^{\circ} \mathrm{C}$ & $8^{\circ} \mathrm{C}$ \\
\hline $400^{\circ} \mathrm{C}$ & $1{ }^{\circ} \mathrm{C}$ & $2^{\circ} \mathrm{C}$ & $3^{\circ} \mathrm{C}$ & $4^{\circ} \mathrm{C}$ & $5^{\circ} \mathrm{C}$ & $5^{\circ} \mathrm{C}$ \\
\hline
\end{tabular}

Tables 4.2-14 and 4.2-15 summarize the peak cladding difference between the helium fill gas case and fill gases of nitrogen and argon, respectively, for the $8 \times 8$ array. Nitrogen is up to $49^{\circ} \mathrm{C}$ hotter and argon is up to $55^{\circ} \mathrm{C}$ hotter than the helium fill gas. However, the difference is greatly reduced at higher temperatures where thermal radiation dominates. In both cases, the fill gas is a significant improvement over vacuum.

Table 4.2-14. Peak Temperature Difference (Nitrogen vs. Helium), 7x7 BWR Assembly

\begin{tabular}{||c||c|c|c|c|c|c||}
\hline \multirow{2}{*}{$\begin{array}{c}\text { Basket Wall } \\
\text { Temperature }\end{array}$} & \multicolumn{7}{|c||}{ Assembly Heat Load } \\
\cline { 2 - 7 } & 100 watts & 200 watts & 300 watts & 400 watts & 500 watts & 600 watts \\
\hline \hline $25^{\circ} \mathrm{C}$ & $12^{\circ} \mathrm{C}$ & $22^{\circ} \mathrm{C}$ & $30^{\circ} \mathrm{C}$ & $37^{\circ} \mathrm{C}$ & $43^{\circ} \mathrm{C}$ & $49^{\circ} \mathrm{C}$ \\
\hline $50^{\circ} \mathrm{C}$ & $10^{\circ} \mathrm{C}$ & $18^{\circ} \mathrm{C}$ & $25^{\circ} \mathrm{C}$ & $32^{\circ} \mathrm{C}$ & $37^{\circ} \mathrm{C}$ & $42^{\circ} \mathrm{C}$ \\
\hline $100^{\circ} \mathrm{C}$ & $7^{\circ} \mathrm{C}$ & $12^{\circ} \mathrm{C}$ & $17^{\circ} \mathrm{C}$ & $22^{\circ} \mathrm{C}$ & $26^{\circ} \mathrm{C}$ & $30^{\circ} \mathrm{C}$ \\
\hline $150^{\circ} \mathrm{C}$ & $4^{\circ} \mathrm{C}$ & $8^{\circ} \mathrm{C}$ & $12^{\circ} \mathrm{C}$ & $15^{\circ} \mathrm{C}$ & $18^{\circ} \mathrm{C}$ & $21^{\circ} \mathrm{C}$ \\
\hline $200^{\circ} \mathrm{C}$ & $3^{\circ} \mathrm{C}$ & $6^{\circ} \mathrm{C}$ & $8^{\circ} \mathrm{C}$ & $11^{\circ} \mathrm{C}$ & $13^{\circ} \mathrm{C}$ & $15^{\circ} \mathrm{C}$ \\
\hline $250^{\circ} \mathrm{C}$ & $2{ }^{\circ} \mathrm{C}$ & $4^{\circ} \mathrm{C}$ & $6^{\circ} \mathrm{C}$ & $8^{\circ} \mathrm{C}$ & $9^{\circ} \mathrm{C}$ & $11^{\circ} \mathrm{C}$ \\
\hline $300^{\circ} \mathrm{C}$ & $1{ }^{\circ} \mathrm{C}$ & $3^{\circ} \mathrm{C}$ & $4^{\circ} \mathrm{C}$ & $5^{\circ} \mathrm{C}$ & $7^{\circ} \mathrm{C}$ & $8^{\circ} \mathrm{C}$ \\
\hline $350^{\circ} \mathrm{C}$ & $1{ }^{\circ} \mathrm{C}$ & $2^{\circ} \mathrm{C}$ & $3^{\circ} \mathrm{C}$ & $4^{\circ} \mathrm{C}$ & $5^{\circ} \mathrm{C}$ & $6^{\circ} \mathrm{C}$ \\
\hline $400^{\circ} \mathrm{C}$ & $1{ }^{\circ} \mathrm{C}$ & $1{ }^{\circ} \mathrm{C}$ & $2^{\circ} \mathrm{C}$ & $3{ }^{\circ} \mathrm{C}$ & $3^{\circ} \mathrm{C}$ & $4{ }^{\circ} \mathrm{C}$ \\
\hline
\end{tabular}


Table 4.2-15. Peak Temperature Difference (Argon vs. Helium), 7x7 BWR Assembly

\begin{tabular}{|c|c|c|c|c|c|c|}
\hline \multirow{2}{*}{$\begin{array}{l}\text { Basket Wall } \\
\text { Temperature }\end{array}$} & \multicolumn{6}{|c|}{ Assembly Heat Load } \\
\hline & 100 watts & 200 watts & 300 watts & 400 watts & 500 watts & 600 watts \\
\hline $25^{\circ} \mathrm{C}$ & $14^{\circ} \mathrm{C}$ & $26^{\circ} \mathrm{C}$ & $35^{\circ} \mathrm{C}$ & $43^{\circ} \mathrm{C}$ & $49^{\circ} \mathrm{C}$ & $55^{\circ} \mathrm{C}$ \\
\hline $50^{\circ} \mathrm{C}$ & $11^{\circ} \mathrm{C}$ & $21^{\circ} \mathrm{C}$ & $29^{\circ} \mathrm{C}$ & $36^{\circ} \mathrm{C}$ & $42^{\circ} \mathrm{C}$ & $47^{\circ} \mathrm{C}$ \\
\hline $100^{\circ} \mathrm{C}$ & $7^{\circ} \mathrm{C}$ & $14^{\circ} \mathrm{C}$ & $20^{\circ} \mathrm{C}$ & $25^{\circ} \mathrm{C}$ & $29^{\circ} \mathrm{C}$ & $34^{\circ} \mathrm{C}$ \\
\hline $150^{\circ} \mathrm{C}$ & $5^{\circ} \mathrm{C}$ & $9^{\circ} \mathrm{C}$ & $14^{\circ} \mathrm{C}$ & $17^{\circ} \mathrm{C}$ & $21^{\circ} \mathrm{C}$ & $24^{\circ} \mathrm{C}$ \\
\hline $200^{\circ} \mathrm{C}$ & $3^{\circ} \mathrm{C}$ & $6^{\circ} \mathrm{C}$ & $9^{\circ} \mathrm{C}$ & $12^{\circ} \mathrm{C}$ & $15^{\circ} \mathrm{C}$ & $17^{\circ} \mathrm{C}$ \\
\hline $250^{\circ} \mathrm{C}$ & $2^{\circ} \mathrm{C}$ & $4^{\circ} \mathrm{C}$ & $7^{\circ} \mathrm{C}$ & $9^{\circ} \mathrm{C}$ & $10^{\circ} \mathrm{C}$ & $12^{\circ} \mathrm{C}$ \\
\hline $300^{\circ} \mathrm{C}$ & $2^{\circ} \mathrm{C}$ & $3^{\circ} \mathrm{C}$ & $5^{\circ} \mathrm{C}$ & $6^{\circ} \mathrm{C}$ & $7^{\circ} \mathrm{C}$ & $9^{\circ} \mathrm{C}$ \\
\hline $350^{\circ} \mathrm{C}$ & $1^{\circ} \mathrm{C}$ & $2^{\circ} \mathrm{C}$ & $3^{\circ} \mathrm{C}$ & $4^{\circ} \mathrm{C}$ & $5^{\circ} \mathrm{C}$ & $6^{\circ} \mathrm{C}$ \\
\hline $400^{\circ} \mathrm{C}$ & $1^{\circ} \mathrm{C}$ & $2^{\circ} \mathrm{C}$ & $2^{\circ} \mathrm{C}$ & $3^{\circ} \mathrm{C}$ & $4^{\circ} \mathrm{C}$ & $5^{\circ} \mathrm{C}$ \\
\hline
\end{tabular}

As expected, the results of the 7x7 BWR assembly in helium are nearly identical to the results for the $9 \times 9$ array. Peak temperatures differed by $1{ }^{\circ} \mathrm{C}$ or less indicating that the two assemblies, both with channels, have nearly identical heat transfer characteristics in helium fill gas. The difference is more pronounced, however, when a vacuum fill is considered. Because the $9 \times 9$ array has one more layer of rods around the perimeter, radiation heat transfer from the center of the assembly to the channel is more difficult (radiation from the channel to the basket wall should be roughly the same for both cases). Peak temperatures were up to $10^{\circ} \mathrm{C}$ lower in the $7 \times 7$ array in a vacuum compared to the $9 \times 9$ array. The results of the nitrogen and argon cases, which depend on radiation more than for the helium case, were bounded by the differences for helium and vacuum.

\subsubsection{Disposal of BWR Assemblies without Channels}

The base BWR SNF models were generated with an 80 mil channel which was standard issue for the GE-2 and GE-5 fuel assembly series. To assess the impact upon peak cladding temperatures the base inputs for the $9 \times 9,8 \times 8$, and $7 \times 7$ arrays were modified to remove the channel. Also the $7 \times 7$ BWR was evaluated for channel thicknesses of 100 mil and 120 mil (as described in Section 3.3.4) to determine the channel thickness trending.

Generally, removal of the channel (which blocks direct thermal radiation from the fuel rods to the basket wall) results in lower peak temperatures. Tables 4.2-16 and 4.2-17 list the peak cladding temperature differences between a 9x9 BWR assembly with an 80 mil channel and one with the channel removed for fill environments of helium and vacuum, respectively. 
Table 4.2-16. Peak Temperature Difference ( 80 mil vs. No Channel), 9x9 BWR in Helium

\begin{tabular}{||c||c|c|c|c|c|c||}
\hline \hline \multirow{2}{*}{\begin{tabular}{|c|} 
Basket Wall \\
Temperature
\end{tabular}} & \multicolumn{6}{|c||}{ Assembly Heat Load } \\
\cline { 2 - 7 } & 100 watts & 200 watts & 300 watts & 400 watts & 500 watts & 600 watts \\
\hline \hline $25^{\circ} \mathrm{C}$ & $0.2^{\circ} \mathrm{C}$ & $0.4^{\circ} \mathrm{C}$ & $0.5^{\circ} \mathrm{C}$ & $0.7^{\circ} \mathrm{C}$ & $1.0^{\circ} \mathrm{C}$ & $1.1^{\circ} \mathrm{C}$ \\
\hline $500^{\circ} \mathrm{C}$ & $0.2^{\circ} \mathrm{C}$ & $0.5^{\circ} \mathrm{C}$ & $0.7^{\circ} \mathrm{C}$ & $1.0^{\circ} \mathrm{C}$ & $1.2^{\circ} \mathrm{C}$ & $1.5^{\circ} \mathrm{C}$ \\
\hline $100^{\circ} \mathrm{C}$ & $0.3^{\circ} \mathrm{C}$ & $0.7^{\circ} \mathrm{C}$ & $1.0^{\circ} \mathrm{C}$ & $1.3^{\circ} \mathrm{C}$ & $1.6^{\circ} \mathrm{C}$ & $1.9^{\circ} \mathrm{C}$ \\
\hline $150^{\circ} \mathrm{C}$ & $0.4^{\circ} \mathrm{C}$ & $0.8^{\circ} \mathrm{C}$ & $1.1^{\circ} \mathrm{C}$ & $1.5^{\circ} \mathrm{C}$ & $1.8^{\circ} \mathrm{C}$ & $2.2^{\circ} \mathrm{C}$ \\
\hline $200^{\circ} \mathrm{C}$ & $0.4^{\circ} \mathrm{C}$ & $0.8^{\circ} \mathrm{C}$ & $1.2^{\circ} \mathrm{C}$ & $1.5^{\circ} \mathrm{C}$ & $1.9^{\circ} \mathrm{C}$ & $2.3^{\circ} \mathrm{C}$ \\
\hline $250^{\circ} \mathrm{C}$ & $0.4^{\circ} \mathrm{C}$ & $0.8^{\circ} \mathrm{C}$ & $1.1^{\circ} \mathrm{C}$ & $1.5^{\circ} \mathrm{C}$ & $1.9^{\circ} \mathrm{C}$ & $2.2^{\circ} \mathrm{C}$ \\
\hline $300^{\circ} \mathrm{C}$ & $0.4^{\circ} \mathrm{C}$ & $0.7^{\circ} \mathrm{C}$ & $1.1^{\circ} \mathrm{C}$ & $1.4^{\circ} \mathrm{C}$ & $1.8^{\circ} \mathrm{C}$ & $2.1^{\circ} \mathrm{C}$ \\
\hline $350^{\circ} \mathrm{C}$ & $0.3^{\circ} \mathrm{C}$ & $0.7^{\circ} \mathrm{C}$ & $1.0^{\circ} \mathrm{C}$ & $1.4^{\circ} \mathrm{C}$ & $1.7^{\circ} \mathrm{C}$ & $2.0^{\circ} \mathrm{C}$ \\
\hline $400^{\circ} \mathrm{C}$ & $0.3^{\circ} \mathrm{C}$ & $0.6^{\circ} \mathrm{C}$ & $1.0^{\circ} \mathrm{C}$ & $1.3^{\circ} \mathrm{C}$ & $1.6^{\circ} \mathrm{C}$ & $1.9^{\circ} \mathrm{C}$ \\
\hline
\end{tabular}

For the helium fill gas, where the high conductivity of the helium gas plays an important heat transfer role, the removal of the channel reduced peak cladding temperatures by only a couple degrees. The central rods have a small radiation view factor to the channel or basket wall which means that the central rods must transfer their heat to other fuel rods first and then the heat will be passed to the channel or basket wall. However, the exterior rod temperatures were substantially lowered with the removal of the channel. The effect of the channel removal on peak cladding temperatures should be even greater for those BWR assemblies which utilize multiple or large central water rods.

For the vacuum case, unlike the helium case, peak cladding temperatures were significantly reduced (up to $17^{\circ} \mathrm{C}$ for the $9 \times 9$ array) by the removal of the channel. This result is consistent with previous trending, since radiation is the only rod-to-basket heat transfer mechanism and the presence of the channel will block direct radiation heat flow from the rods to the basket. The channel differences for the fill gases of nitrogen (up to $10^{\circ} \mathrm{C}$ ) and argon (up to $12^{\circ} \mathrm{C}$ ) were bounded by the helium and vacuum results as nitrogen and argon rely on radiation heat transfer more than helium.

Similar trending for the removal of the channel was observed for the $8 \times 8$ and $7 \times 7$ BWR assemblies. For the $7 \times 7$ array, the center rod has a better radiation heat transfer path to the channel or basket wall than in the $9 \times 9$ array, therefore the removal of the channel is expected to have a larger impact. In a helium fill gas, removal of the channel reduced peak temperatures in the $7 \times 7$ array up to $4{ }^{\circ} \mathrm{C}$; and in a vacuum, peak temperatures were reduced up to $22^{\circ} \mathrm{C}$. Similar to the $9 \times 9$, removal of the channel resulted in drops up to $14^{\circ} \mathrm{C}$ and $16^{\circ} \mathrm{C}$ in nitrogen and argon, respectively. The channel results for the $8 \times 8$ BWR assembly were bounded by those of the $9 \times 9$ and $7 \times 7$. Channel effects on the determination of effective thermal conductivity is discussed in Section 6. 
Table 4.2-17. Peak Temperature Difference ( 80 mil vs. No Channel), 9x9 BWR in Vacuum

\begin{tabular}{||c||c|c|c|c|c|c||}
\hline \multirow{2}{*}{\begin{tabular}{|} 
Basket Wall \\
Temperature
\end{tabular}} & \multicolumn{6}{|c||}{ Assembly Heat Load } \\
\cline { 2 - 7 } & 100 watts & 200 watts & 300 watts & 400 watts & 500 watts & 600 watts \\
\hline \hline $25^{\circ} \mathrm{C}$ & $5.6^{\circ} \mathrm{C}$ & $9.1^{\circ} \mathrm{C}$ & $11.7^{\circ} \mathrm{C}$ & $13.7^{\circ} \mathrm{C}$ & $15.3^{\circ} \mathrm{C}$ & $16.6^{\circ} \mathrm{C}$ \\
\hline $50^{\circ} \mathrm{C}$ & $4.7^{\circ} \mathrm{C}$ & $8.0^{\circ} \mathrm{C}$ & $10.5^{\circ} \mathrm{C}$ & $12.5^{\circ} \mathrm{C}$ & $14.1^{\circ} \mathrm{C}$ & $15.6^{\circ} \mathrm{C}$ \\
\hline $100^{\circ} \mathrm{C}$ & $3.4^{\circ} \mathrm{C}$ & $6.1^{\circ} \mathrm{C}$ & $8.3^{\circ} \mathrm{C}$ & $10.2^{\circ} \mathrm{C}$ & $11.8^{\circ} \mathrm{C}$ & $13.2^{\circ} \mathrm{C}$ \\
\hline $150^{\circ} \mathrm{C}$ & $2.5^{\circ} \mathrm{C}$ & $4.6^{\circ} \mathrm{C}$ & $6.5^{\circ} \mathrm{C}$ & $8.1^{\circ} \mathrm{C}$ & $9.6^{\circ} \mathrm{C}$ & $11.0^{\circ} \mathrm{C}$ \\
\hline $200^{\circ} \mathrm{C}$ & $1.9^{\circ} \mathrm{C}$ & $3.5^{\circ} \mathrm{C}$ & $5.0^{\circ} \mathrm{C}$ & $6.4^{\circ} \mathrm{C}$ & $7.7^{\circ} \mathrm{C}$ & $8.9^{\circ} \mathrm{C}$ \\
\hline $250^{\circ} \mathrm{C}$ & $1.4^{\circ} \mathrm{C}$ & $2.7^{\circ} \mathrm{C}$ & $4.0^{\circ} \mathrm{C}$ & $5.1^{\circ} \mathrm{C}$ & $6.2^{\circ} \mathrm{C}$ & $7.2^{\circ} \mathrm{C}$ \\
\hline $300^{\circ} \mathrm{C}$ & $1.1^{\circ} \mathrm{C}$ & $2.1^{\circ} \mathrm{C}$ & $3.1^{\circ} \mathrm{C}$ & $4.1^{\circ} \mathrm{C}$ & $5.0^{\circ} \mathrm{C}$ & $5.9^{\circ} \mathrm{C}$ \\
\hline $350^{\circ} \mathrm{C}$ & $0.9^{\circ} \mathrm{C}$ & $1.7^{\circ} \mathrm{C}$ & $2.5^{\circ} \mathrm{C}$ & $3.3^{\circ} \mathrm{C}$ & $4.1^{\circ} \mathrm{C}$ & $4.8^{\circ} \mathrm{C}$ \\
\hline $400^{\circ} \mathrm{C}$ & $0.7^{\circ} \mathrm{C}$ & $1.4^{\circ} \mathrm{C}$ & $2.0^{\circ} \mathrm{C}$ & $2.7^{\circ} \mathrm{C}$ & $3.3^{\circ} \mathrm{C}$ & $3.9^{\circ} \mathrm{C}$ \\
\hline
\end{tabular}

For the $7 \times 7$ BWR assembly, the 80 mil channel results were compared to results for channel thicknesses of $100 \mathrm{mil}$ and $120 \mathrm{mil}$ in fill environments of helium and vacuum. Comparing the peak cladding temperature results for the three channel thickness, it is seen that the each of the channel thickness generated the same peak cladding temperature results within $0.5^{\circ} \mathrm{C}$ in both helium fill gas and in vacuum. This result is also not totally unexpected since the channel conductivities are high enough that a 20 mil to 40 mil thickness increase represents less than a $1{ }^{\circ} \mathrm{C}$ increase in the temperature drop across the channel thickness. This effect was not seen to change with fill gas (even vacuum). Thus, we can conclude that the peak cladding temperatures will be nearly the same with any channel thickness currently being used in the reactor cores (and that channel thickness variations will not impact our determination of effective thermal conductivity).

\subsubsection{BWR Designs with Water Rods}

One of the innovations in the design of BWR fuel assemblies to increase the in-core uranium utilization was the substitution of one or more fuel rods with one or more water rods. As described in Section 3.3.5, models were developed for each of the BWR assembly geometries that included a water rod or channel replacing one or more fuel rods in the center of the BWR assembly in order to bound the effects of all water rod configurations which have been manufactured to date. In a dry environment, the only effect of the water rod is to displace heat producing spent fuel rods.

The C-lattice water rod configuration for $7 \times 7$ BWR assembly was evaluated for each of the 54 temperature and heat cases in each of the four fill environments (helium, vacuum, nitrogen, and argon) with and without an 80 mil channel. Comparing solution results with the corresponding results generated for the base $7 \times 7$ BWR fuel assembly, we find that the peak cladding temperatures calculated for the water rod $7 \times 7$ BWR fuel assembly are $0.5^{\circ} \mathrm{C}$ to $2.0^{\circ} \mathrm{C}$ less. Closely examining 
the results shows that there is not a trend or bias for a fill gas environment or for an assembly with or without a channel. Each individual condition (i.e., fill gas and channel case) displayed the a $0.5^{\circ} \mathrm{C}$ to $2.0^{\circ} \mathrm{C}$ peak cladding temperature reduction. Thus, a single water rod placed at the center of the $7 \times 7$ BWR fuel assembly (the optimal position for reducing peak cladding temperatures) will reduce the peak cladding temperature by a maximum of $2.0^{\circ} \mathrm{C}$ for any of the fill gas environments considered in this evaluation. Water rods placed in a different location (i.e., a D-Lattice configuration) will reduce the peak cladding temperature by less than $2.0^{\circ} \mathrm{C}$ for any of the fill gas environments considered in this evaluation. This is a relatively small reduction in peak cladding temperature. Thus, using the base 7x7 BWR SNF assembly model results to characterize $7 \times 7$ BWR assemblies with a water rod is conservative. However, the level of conservatism is small and should not consequently force any container design to be excessively conservative.

The results for the $8 \times 8 \mathrm{BWR}$ assemblies with single over-sized water rod are dramatically different than the 7x7 BWR assemblies, and the 9x9 BWR assembly results are very similar to the $8 \times 8$ BWR results. The $8 \times 8$ and $9 \times 9$ rod array differs from the $7 \times 7$ rod array due to the displacement of the four center-most fuel rods in the $8 \times 8$ assembly and the nine center-most fuel rods in the $9 \times 9$ assembly. This has the effect of significantly shifting the interior heat generation toward the edge of the assembly. The $8 \times 8$ and $9 \times 9$ assemblies have larger surface areas with which to transfer heat than the $7 \times 7$ assembly since the heat generation is spread to 12 more fuel rods for the $8 \times 8$ and 24 more fuel rods for the $9 \times 9$ (which reduced the individual fuel pin heat generation rate for equivalent assembly powers). This effect can be seen most dramatically with the results for the vacuum environment which does not have a fill gas to provided a conduction path for heat removal. The $8 \times 8$ and $9 \times 9$ assemblies have a slightly lower heat generation per fuel rod than and $7 \times 7$ assembly, and additional rod surface area in each row which can see the basket wall. Thus, the removal of four central fuel rods for the $8 \times 8$ and nine central fuel rods for the $9 \times 9$ provides a greater reduction in heat generation in the center and provides more radiation surface area at the exterior of the $8 \times 8$ and $9 \times 9$ assemblies.

The $8 \times 8$ and $9 \times 9$ water rod geometries have very similar results due to the fact that each geometry is basically three rows of fuel rods deep. Thus, they have nearly the same basic radiation and conduction paths. The $9 \times 9$ water rod geometry were approximately $0.4^{\circ} \mathrm{C}$ cooler than the $8 \times 8$ water rod geometry due to the additional rod surface area for conduction and radiation. For the helium fill gas, peak cladding temperatures calculated for the water rod $9 \times 9$ BWR fuel assembly are $0.3^{\circ} \mathrm{C}$ to $8^{\circ} \mathrm{C}$ less than the peak cladding temperatures calculated for the base $9 \times 9$ BWR fuel assembly. For vacuum, peak cladding temperatures calculated for the water rod 9x9 BWR fuel assembly are $0.4^{\circ} \mathrm{C}$ to $18^{\circ} \mathrm{C}$ less than the peak cladding temperatures calculated for the base $9 \times 9$ BWR fuel assembly. For nitrogen and argon, the differences were up to $15^{\circ} \mathrm{C}$ and $16^{\circ} \mathrm{C}$, respectively. Also, the temperature effect of the water rod was the same both with and without an assembly channel.

The 9x9 BWR SNF assembly designs which use from one to five fuel-rod-sized water rods or two over-sized water rods ( 8 fuel rods) will have peak cladding temperatures which fall in between the base case as the upper bound and the single over-sized water channel case as the lower bound. Thus, using the base 9x9 BWR SNF assembly model results to characterize 9x9 BWR assemblies with a water rod(s) is conservative. However, the level of conservatism is small for helium fill gas environments and should not force any container design to be excessively conservative. 


\subsubsection{Cladding Oxidation Layer Effects}

The cladding outer surface oxidation layer thickness has two effects upon the heat transfer modes of SNF, the first is a change in cladding surface emissivity and the second is as an insulator. As presented by Equation B-3.1b of the MATPRO Handbook ${ }^{[10]}$ and Assumption 1.4-10: 1) the emissivity of SNF cladding changes very slowly with oxide thickness, 2 ) the oxide layer typically grows at a modest rate, 3 ) the oxide layer is typically very small (i.e., 2 to 4 mils or less), and 4) will have a very small or negligible effect upon the resulting peak cladding temperatures experience by PWR and BWR SNF.

The variation of cladding emissivity for any of a variety of reasons is discussed in the following Section 4.2.7. Thus, the focus of this section is the insulating effect which a growing cladding oxide layer will have upon the prediction of peak cladding temperatures. Given the thermal conductivity of the zirconium dioxide, ${ }^{[49]}$ a 4 mil oxide layer thickness on a BWR assembly, and the range of BWR assembly heat loads considered in this evaluation (100 to 600 watts), the temperature drop across the oxide layer ranges from $0.06^{\circ} \mathrm{C}$ to $0.35^{\circ} \mathrm{C}$. These temperature drops are very small and do not have a significant impact upon predicting peak cladding temperatures. However, the question concerning effect of doubling or tripling the oxide layer thickness remains. The temperature drop across an annular thickness of material is given by Equation 4.2-1: $:^{[1]}$

$$
\left(T_{i}-T_{o}\right)=\frac{Q \ln \left(r_{o} / r_{i}\right)}{2 \pi L_{a} k}
$$

(Equation 4.2-1)

Where: $\quad T_{i} \quad$ is the temperature at the inner radius of the oxide layer

$T_{o} \quad$ is the temperature at the outer radius of the oxide layer

$Q \quad$ is the SNF rod heat generation rate

$r_{i} \quad$ is the inner radius of the oxide layer

$r_{o} \quad$ is the outer radius of the oxide layer

$L_{a} \quad$ is the active length of the SNF assembly

$\mathrm{k} \quad$ is the effective thermal conductivity of the oxide layer

The temperature drop across the cladding oxide layer depends upon the natural log of the ratio of the outer and inner radius of the oxide layer given constant geometry, material properties, and heat load. Since the oxide layer thickness $(d)$ is simply:

$$
d=r_{o}-r_{i}
$$

(Equation 4.2-2) 
The natural log term of Equation 4.2-1 can be rewritten as:

$$
\left(T_{i}-T_{o}\right)=\frac{Q \ln \left(1+d / r_{i}\right)}{2 \pi L_{a} k}
$$

(Equation 4.2-3)

Table 4.2-18 presents data created by evaluating the nature log term of Equation 4.2-3 for a oxide layer inner radius equal to that of the SNF rod outer radius and the oxide layer thicknesses of 4 mils (reference), 8 mils (two times), and 12 mils (three times). Based on Table 4.2-18, it can be concluded that the insulating effect of cladding oxide layers has a negligible impact upon the prediction of peak cladding temperatures (and therefore effective thermal conductivity). Oxide layer thicknesses for BWR SNF even at high burnups will not be significantly greater than 4 mils. Thus, peak cladding temperature predictions will vary by less then $1{ }^{\circ} \mathrm{C}$ due to any insulating effects of cladding oxide layer thickness variations.

Table 4.2-18. Oxide Layer Temperature Drop Versus Oxide Layer Thickness

\begin{tabular}{|c|c|c|}
\hline Oxide Layer Thickness & Value of $\ln \left(1+d / r_{i}\right)$ & Delta Temperature Range \\
\hline \hline 0.004 inches & 0.01411 & $0.060^{\circ} \mathrm{C}$ to $0.350^{\circ} \mathrm{C}$ \\
\hline 0.008 inches & 0.02802 & $0.119^{\circ} \mathrm{C}$ to $0.685^{\circ} \mathrm{C}$ \\
\hline 0.012 inches & 0.04175 & $0.178^{\circ} \mathrm{C}$ to $1.036^{\circ} \mathrm{C}$ \\
\hline
\end{tabular}

\subsubsection{Emissivity Variation Effects}

The emissivity of both the SNF cladding and the basket wall can vary due to any number of items including, but not limited to, variances in the oxide layer, crud buildup, surface finish or fabrication variances, or material flaws. These variances in turn can alter the radiation heat transfer characteristics of the surfaces and therefore change the peak cladding temperatures. The post-test analysis for the REA 2023 BWR spent fuel storage cask ${ }^{[21]}$ examined the effect of surface emissivity variations with the HYDRA and COBRA codes. Both of these codes included gaseous conduction, convection, and thermal radiation in the analyses. The REA base analysis performed assumed an SNF cladding emittance value of 0.8 . The SNF emittance was reduced to 0.6 to evaluate the effect upon the peak cladding prediction of a single test run. A similar change was made for the emittance of the basket wall, from a base emittance of 0.2 to a higher value of 0.3 . Each change was evaluated independently. The conclusion drawn ${ }^{[21]}$ is that the predicted peak SNF rod temperatures are not significantly affected by the fuel rod or SNF basket wall emittance values. The conclusion is based upon the fact that the change in peak cladding temperature due to a change in the surface emittance values resulted in a $4^{\circ} \mathrm{C}$ or less change $e^{[21]}$ in peak cladding temperature. This change in predicted 
peak cladding temperatures is small given the magnitude of the emittance value change and suggests that the peak cladding temperature is relatively insensitive to small changes in emissivity values.

The SNF emittance values used here are consistent with the range determined in the BWR cask tests. ${ }^{[2]}$ Thus, it is believed that the ability of the ANSYS PWR and BWR SNF assembly modeling methods presented in this evaluation to predict SNF peak cladding temperatures will not be affected by small changes in SNF rod emittance values. However, the selection of basket wall material and its surface finish could potentially impact the prediction of peak cladding temperatures. If a design were to select a material or finish which has an emittance value which was significantly lower than the value used for the basket wall in this evaluation, then peak cladding predictions could be under predicted. Conversely, if a material or finish which has an emittance value which was significantly higher than the value used for the basket wall in this evaluation, then peak cladding predictions could be over predicted. The analysis provided in the BWR cask tests ${ }^{[21]}$ suggest that a 0.1 change in the emittance of the basket wall surface results in an approximately $4^{\circ} \mathrm{C}$ change in the peak cladding temperature prediction. While, this is only a single point, it can be used as a guide in determining how the SNF models will perform with regard to basket wall surface effects.

\subsubsection{Basket Wall Temperature Gradient Effects}

The analysis presented in this report assumes a constant basket wall temperature; however, this condition is rarely encountered in an SNF container. A temperature gradient from one corner of the basket to another corner of the basket means that the SNF rods will see different temperatures for radiation heat transfer. These variances can alter the radiation heat transfer characteristics (and therefore peak temperatures) of the surfaces due to the fact that radiation heat transfer depends on absolute temperature raised to the fourth power.

The post-test analysis for the REA 2023 BWR spent fuel storage cask ${ }^{[21]}$ examined the effect of a temperature gradient across the basket with the HYDRA code. In that analysis, the basket wall was modeled with a nearly constant wall temperature and with a linear temperature gradient having a fairly large slope. The results showed that the change in peak cladding temperature predicted was approximately $2{ }^{\circ} \mathrm{C}$. The report then went on to conclude that SNF basket wall temperature gradients are not of major importance in predicting peak cladding temperatures. The HYDRA code modeled the SNF assemblies and the basket structure explicitly, in a manner similar to the modeling method used for this evaluation. However, the HYDRA code does model convective heat transfer for buoyancy driven gas flow in addition to conduction and radiative heat transfer modes. The analyses presented here include conduction and radiation heat transfer models only, and therefore should have some conservatism built into the method. Based upon this modeling convention and the BWR cask analysis ${ }^{[21]}$ it is believed that the basket wall temperature gradients will not significantly impact the ability of the SNF assembly modeling method to predict SNF peak cladding temperatures. Also, a benchmark of the effective thermal conductivity method (derived from the SNF model results) is performed in Section 7.3 where peak temperatures are compared to experimental data ${ }^{[23]}$ with full basket thermal gradients in the TN-24P PWR storage cask. 


\section{Wooton-Epstein Comparisons}

To check the discrete SNF assembly model results of Section 4, the Wooton-Epstein correlation ${ }^{[5]}$ was applied for each of the assembly geometries. This empirically derived correlation was shown to be conservative for helium fill gas in Section 3.6.2 of the BR-100 Spent Fuel Shipping Cask report. ${ }^{[32]}$ The Wooton-Epstein relationship (described by Equation 5.0-1) is based on a set of experiments performed in 1963 for an array of rods (17x18) in air.

$$
q^{\prime \prime}=\sigma \frac{C_{1}}{\frac{1}{\epsilon_{c l}}+\frac{1}{\epsilon_{b a}}-1}\left(T_{c l}^{4}-T_{b a}^{4}\right)+C_{2}\left(T_{c l}-T_{b a}\right)^{\frac{4}{3}}
$$

Where:

(Equation 5.0-1)

$q^{\prime \prime} \quad=$ heat flux from SNF based on the basket inner surface heat transfer area $\left(\mathrm{Btu} / \mathrm{hr} \cdot \mathrm{ft}^{2}\right)$

$C_{1} \quad=$ constant depending on the spent fuel rod array size, $=4 N /(N+1)^{2}$ for odd $N$

$=4 /(N+2)$ for even $N$

$C_{2} \quad=$ regression constant $=0.118$

$N \quad$ = number of fuel rods in a single row of a square spent fuel assembly

$T_{c l} \quad=$ cladding surface temperature (absolute scale, ${ }^{\circ} \mathrm{R}$ )

$T_{b a} \quad=$ basket surface temperature (absolute scale, ${ }^{\circ} \mathrm{R}$ )

$\epsilon_{c l} \quad=$ cladding surface emissivity

$\epsilon_{b a} \quad=$ basket surface emissivity

$\sigma \quad=$ Stefan-Boltzmann constant $\left(\mathrm{Btu} / \mathrm{hr} \cdot \mathrm{ft}^{2} \cdot{ }^{\circ} \mathrm{R}^{4}\right)$

The relationship has two terms; one representing radiation heat transfer, and one representing gaseous convection in an array of heat producing rods. Because the cladding temperature occurs in both terms, the relation must be solved iteratively. A complete description of the correlation development is given in the Wooton-Epstein paper ${ }^{[5]}$ In the following sections, the Wooton-Epstein correlation is applied to each of the assembly geometries considered in Sections 3 and 4 for the same set of basket temperatures and assembly heat loads. 


\subsection{PWR Assembly Geometries}

\subsubsection{Wooton-Epstein for $17 \times 17$ Array}

For this evaluation, the same material properties, assembly dimensions, and heat peaking factor were assumed with the Wooton-Epstein correlation that were used in the discrete PWR SNF model in previous sections. Table 5.1-1 summarizes the peak cladding results of the Wooton-Epstein calculation and Table 7.5-2 provides the calculated cladding-to-basket temperature drops $(\Delta T)$. Details of this calculation can be found in the supporting PWR design analysis. ${ }^{[48]}$

Table 5.1-1. Peak Cladding Temperatures, Wooton-Epstein Correlation (17x17)

\begin{tabular}{||c||c|c|c|c|}
\hline \multirow{2}{*}{$\begin{array}{c}\text { Basket Wall } \\
\text { Temperature }\end{array}$} & \multicolumn{4}{|c|}{ Assembly Heat Load } \\
\cline { 2 - 5 } & 250 watts & 500 watts & 750 watts & 1000 watts \\
\hline \hline $25^{\circ} \mathrm{C}$ & $52^{\circ} \mathrm{C}$ & $72^{\circ} \mathrm{C}$ & $89^{\circ} \mathrm{C}$ & $104^{\circ} \mathrm{C}$ \\
\hline $50^{\circ} \mathrm{C}$ & $76^{\circ} \mathrm{C}$ & $95^{\circ} \mathrm{C}$ & $111^{\circ} \mathrm{C}$ & $126^{\circ} \mathrm{C}$ \\
\hline $100^{\circ} \mathrm{C}$ & $123^{\circ} \mathrm{C}$ & $141^{\circ} \mathrm{C}$ & $156^{\circ} \mathrm{C}$ & $170^{\circ} \mathrm{C}$ \\
\hline $150^{\circ} \mathrm{C}$ & $171^{\circ} \mathrm{C}$ & $186^{\circ} \mathrm{C}$ & $200^{\circ} \mathrm{C}$ & $213^{\circ} \mathrm{C}$ \\
\hline $200^{\circ} \mathrm{C}$ & $218^{\circ} \mathrm{C}$ & $232^{\circ} \mathrm{C}$ & $245^{\circ} \mathrm{C}$ & $256^{\circ} \mathrm{C}$ \\
\hline $250^{\circ} \mathrm{C}$ & $265^{\circ} \mathrm{C}$ & $278^{\circ} \mathrm{C}$ & $289^{\circ} \mathrm{C}$ & $300^{\circ} \mathrm{C}$ \\
\hline $300^{\circ} \mathrm{C}$ & $313^{\circ} \mathrm{C}$ & $324^{\circ} \mathrm{C}$ & $334^{\circ} \mathrm{C}$ & $343^{\circ} \mathrm{C}$ \\
\hline $350^{\circ} \mathrm{C}$ & $361^{\circ} \mathrm{C}$ & $371{ }^{\circ} \mathrm{C}$ & $379^{\circ} \mathrm{C}$ & $388^{\circ} \mathrm{C}$ \\
\hline $400^{\circ} \mathrm{C}$ & $409^{\circ} \mathrm{C}$ & $418^{\circ} \mathrm{C}$ & $425^{\circ} \mathrm{C}$ & $433^{\circ} \mathrm{C}$ \\
\hline
\end{tabular}

As expected, the Wooton-Epstein correlation over-predicts peak temperatures, compared to the discrete SNF assembly model with a helium fill gas. For a fill gas of helium, the $\Delta T$ was roughly twice that predicted by the 17x17 PWR SNF assembly model. Compared to the discrete SNF model evaluations with vacuum, nitrogen, and argon, however, the Wooton-Epstein correlation was seen to be only slightly conservative at higher temperatures and somewhat nonconservative (predicting lower temperatures) for low basket wall temperatures. Table 5.1-3 provides a peak temperatures comparison table between the Wooton-Epstein results and peak temperatures predicted by the $17 \times 17$ PWR SNF assembly model with nitrogen fill gas (nitrogen is similar to air). Wooton-Epstein is seen to predict significantly lower temperatures for very high heat loads with very low SNF basket temperatures. However, the correlation is still seen to be slightly conservative (for nitrogen fill gas) for more likely temperatures and heat loads that would be expected in SNF disposal devices. 
Table 5.1-2. Cladding-to-Basket Delta T, Wooton-Epstein Correlation (17x17)

\begin{tabular}{||c||c|c|c|c|}
\hline \multirow{2}{*}{$\begin{array}{c}\text { Basket Wall } \\
\text { Temperature }\end{array}$} & \multicolumn{4}{|c|}{ Assembly Heat Load } \\
\cline { 2 - 5 } & 250 watts & 500 watts & 750 watts & 1000 watts \\
\hline $255^{\circ} \mathrm{C}$ & $27^{\circ} \mathrm{C}$ & $47^{\circ} \mathrm{C}$ & $64^{\circ} \mathrm{C}$ & $79^{\circ} \mathrm{C}$ \\
\hline $50^{\circ} \mathrm{C}$ & $26^{\circ} \mathrm{C}$ & $45^{\circ} \mathrm{C}$ & $61^{\circ} \mathrm{C}$ & $76^{\circ} \mathrm{C}$ \\
\hline $100^{\circ} \mathrm{C}$ & $23^{\circ} \mathrm{C}$ & $41^{\circ} \mathrm{C}$ & $56^{\circ} \mathrm{C}$ & $70^{\circ} \mathrm{C}$ \\
\hline $150^{\circ} \mathrm{C}$ & $21^{\circ} \mathrm{C}$ & $36^{\circ} \mathrm{C}$ & $50^{\circ} \mathrm{C}$ & $63^{\circ} \mathrm{C}$ \\
\hline $200^{\circ} \mathrm{C}$ & $18^{\circ} \mathrm{C}$ & $32^{\circ} \mathrm{C}$ & $45^{\circ} \mathrm{C}$ & $56^{\circ} \mathrm{C}$ \\
\hline $250^{\circ} \mathrm{C}$ & $15^{\circ} \mathrm{C}$ & $28^{\circ} \mathrm{C}$ & $39^{\circ} \mathrm{C}$ & $50^{\circ} \mathrm{C}$ \\
\hline $300^{\circ} \mathrm{C}$ & $13^{\circ} \mathrm{C}$ & $24^{\circ} \mathrm{C}$ & $34^{\circ} \mathrm{C}$ & $43^{\circ} \mathrm{C}$ \\
\hline $350^{\circ} \mathrm{C}$ & $11^{\circ} \mathrm{C}$ & $21^{\circ} \mathrm{C}$ & $29^{\circ} \mathrm{C}$ & $38^{\circ} \mathrm{C}$ \\
\hline $400^{\circ} \mathrm{C}$ & $9{ }^{\circ} \mathrm{C}$ & $18^{\circ} \mathrm{C}$ & $25^{\circ} \mathrm{C}$ & $33^{\circ} \mathrm{C}$ \\
\hline
\end{tabular}

Table 5.1-3. Peak Temperature Difference (Wooton-Epstein vs. 17x17 PWR in Nitrogen)

\begin{tabular}{|c|c|c|c|c|}
\hline \multirow{2}{*}{$\begin{array}{l}\text { Basket Wall } \\
\text { Temperature }\end{array}$} & \multicolumn{4}{|c|}{ Assembly Heat Load } \\
\hline & 250 watts & 500 watts & 750 watts & 1000 watts \\
\hline $25^{\circ} \mathrm{C}$ & $-9^{\circ} \mathrm{C}$ & $-19^{\circ} \mathrm{C}$ & $-27^{\circ} \mathrm{C}$ & $-33^{\circ} \mathrm{C}$ \\
\hline $50^{\circ} \mathrm{C}$ & $-5^{\circ} \mathrm{C}$ & $-12^{\circ} \mathrm{C}$ & $-19^{\circ} \mathrm{C}$ & $-24^{\circ} \mathrm{C}$ \\
\hline $100^{\circ} \mathrm{C}$ & $0^{\circ} \mathrm{C}$ & $-3^{\circ} \mathrm{C}$ & $-6^{\circ} \mathrm{C}$ & $-10^{\circ} \mathrm{C}$ \\
\hline $150^{\circ} \mathrm{C}$ & $3^{\circ} \mathrm{C}$ & $2^{\circ} \mathrm{C}$ & $1^{\circ} \mathrm{C}$ & $0^{\circ} \mathrm{C}$ \\
\hline $200^{\circ} \mathrm{C}$ & $4^{\circ} \mathrm{C}$ & $5^{\circ} \mathrm{C}$ & $6^{\circ} \mathrm{C}$ & $6^{\circ} \mathrm{C}$ \\
\hline $250^{\circ} \mathrm{C}$ & $4^{\circ} \mathrm{C}$ & $6^{\circ} \mathrm{C}$ & $8^{\circ} \mathrm{C}$ & $9^{\circ} \mathrm{C}$ \\
\hline $300^{\circ} \mathrm{C}$ & $4^{\circ} \mathrm{C}$ & $7^{\circ} \mathrm{C}$ & $9^{\circ} \mathrm{C}$ & $10^{\circ} \mathrm{C}$ \\
\hline $350^{\circ} \mathrm{C}$ & $4^{\circ} \mathrm{C}$ & $6^{\circ} \mathrm{C}$ & $9^{\circ} \mathrm{C}$ & $10^{\circ} \mathrm{C}$ \\
\hline $400^{\circ} \mathrm{C}$ & $3^{\circ} \mathrm{C}$ & $6^{\circ} \mathrm{C}$ & $8^{\circ} \mathrm{C}$ & $10^{\circ} \mathrm{C}$ \\
\hline
\end{tabular}




\subsubsection{Wooton-Epstein for $15 \times 15$ Array}

The Wooton-Epstein correlation was also evaluated for the 15x15 PWR SNF assembly. Temperature results were similar to those for the $17 \times 17$ assembly and the differences are listed in Table 5.1-4. Generally the $17 \times 17$ assembly resulted in higher peak cladding temperatures; however, the difference was only as much as about $2{ }^{\circ} \mathrm{C}$. This result indicates that the Wooton-Epstein correlation is not sensitive to small variations in the number of rods in the assembly and that the results for the $17 \times 17$ array are representative of this temperature prediction method for PWR assemblies.

Table 5.1-4. Peak Temperature Difference (Wooton-Epstein $17 \times 17$ vs. $15 \times 15$ )

\begin{tabular}{||c||c|c|c|c||}
\hline \multirow{2}{*}{$\begin{array}{c}\text { Basket Wall } \\
\text { Temperature }\end{array}$} & \multicolumn{4}{|c|}{ Assembly Heat Load } \\
\cline { 2 - 5 } & 250 watts & 500 watts & 750 watts & 1000 watts \\
\hline $25^{\circ} \mathrm{C}$ & $0.3^{\circ} \mathrm{C}$ & $0.4^{\circ} \mathrm{C}$ & $0.5^{\circ} \mathrm{C}$ & $0.6^{\circ} \mathrm{C}$ \\
\hline $50^{\circ} \mathrm{C}$ & $0.3^{\circ} \mathrm{C}$ & $0.5^{\circ} \mathrm{C}$ & $0.7^{\circ} \mathrm{C}$ & $0.8^{\circ} \mathrm{C}$ \\
\hline $100^{\circ} \mathrm{C}$ & $0.5^{\circ} \mathrm{C}$ & $0.8^{\circ} \mathrm{C}$ & $1.0^{\circ} \mathrm{C}$ & $1.2^{\circ} \mathrm{C}$ \\
\hline $150^{\circ} \mathrm{C}$ & $0.7^{\circ} \mathrm{C}$ & $1.0^{\circ} \mathrm{C}$ & $1.3^{\circ} \mathrm{C}$ & $1.6^{\circ} \mathrm{C}$ \\
\hline $200^{\circ} \mathrm{C}$ & $0.7^{\circ} \mathrm{C}$ & $1.2^{\circ} \mathrm{C}$ & $1.5^{\circ} \mathrm{C}$ & $1.8^{\circ} \mathrm{C}$ \\
\hline $250^{\circ} \mathrm{C}$ & $0.8^{\circ} \mathrm{C}$ & $1.2^{\circ} \mathrm{C}$ & $1.6^{\circ} \mathrm{C}$ & $2.0^{\circ} \mathrm{C}$ \\
\hline $300^{\circ} \mathrm{C}$ & $0.7^{\circ} \mathrm{C}$ & $1.2^{\circ} \mathrm{C}$ & $1.7^{\circ} \mathrm{C}$ & $2.1^{\circ} \mathrm{C}$ \\
\hline $350^{\circ} \mathrm{C}$ & $0.7^{\circ} \mathrm{C}$ & $1.2^{\circ} \mathrm{C}$ & $1.6^{\circ} \mathrm{C}$ & $2.0^{\circ} \mathrm{C}$ \\
\hline $400^{\circ} \mathrm{C}$ & $0.6^{\circ} \mathrm{C}$ & $1.1^{\circ} \mathrm{C}$ & $1.6^{\circ} \mathrm{C}$ & $2.0^{\circ} \mathrm{C}$ \\
\hline
\end{tabular}

\subsubsection{Wooton-Epstein for $14 \times 14$ Array}

To confirm the trending above, the Wooton-Epstein correlation was also evaluated for the $14 \times 14$ PWR SNF assembly. Temperature results were similar to those for the $17 \times 17$ assembly and the differences are listed in Table 5.1-5. Generally the $14 \times 14$ assembly resulted in slightly lower peak cladding temperatures; however some values were higher. In this case the effects of reducing the number or rods (expected to lower peak temperatures for radiation dominated conditions) was offset by the shorter length of the 14x14 PWR assembly (increasing the heat per assembly length). Again, this result indicates that the Wooton-Epstein correlation is not sensitive to small variations in the number of rods in the assembly and that the results for the $17 \times 17$ array are representative of this temperature prediction method for PWR assemblies. 
Table 5.1-5. Peak Temperature Difference (Wooton-Epstein $17 \times 17$ vs. $14 \times 14$ )

\begin{tabular}{||c||c|c|c|c||}
\hline \multirow{2}{*}{$\begin{array}{c}\text { Basket Wall } \\
\text { Temperature }\end{array}$} & \multicolumn{4}{|c||}{ Assembly Heat Load } \\
\cline { 2 - 5 } & 250 watts & 500 watts & 750 watts & 1000 watts \\
\hline \hline \multicolumn{1}{||}{$25^{\circ} \mathrm{C}$} & $-0.2^{\circ} \mathrm{C}$ & $-0.4^{\circ} \mathrm{C}$ & $-0.5^{\circ} \mathrm{C}$ & $-0.7^{\circ} \mathrm{C}$ \\
\hline $50{ }^{\circ} \mathrm{C}$ & $0.0^{\circ} \mathrm{C}$ & $-0.1^{\circ} \mathrm{C}$ & $-0.2^{\circ} \mathrm{C}$ & $-0.2^{\circ} \mathrm{C}$ \\
\hline $100^{\circ} \mathrm{C}$ & $0.3^{\circ} \mathrm{C}$ & $0.4^{\circ} \mathrm{C}$ & $0.5^{\circ} \mathrm{C}$ & $0.6^{\circ} \mathrm{C}$ \\
\hline $150^{\circ} \mathrm{C}$ & $0.6^{\circ} \mathrm{C}$ & $0.9^{\circ} \mathrm{C}$ & $1.1^{\circ} \mathrm{C}$ & $1.2^{\circ} \mathrm{C}$ \\
\hline $200^{\circ} \mathrm{C}$ & $0.8^{\circ} \mathrm{C}$ & $1.2^{\circ} \mathrm{C}$ & $1.5^{\circ} \mathrm{C}$ & $1.8^{\circ} \mathrm{C}$ \\
\hline $250^{\circ} \mathrm{C}$ & $0.9^{\circ} \mathrm{C}$ & $1.4^{\circ} \mathrm{C}$ & $1.8^{\circ} \mathrm{C}$ & $2.1^{\circ} \mathrm{C}$ \\
\hline $300^{\circ} \mathrm{C}$ & $0.9^{\circ} \mathrm{C}$ & $1.4^{\circ} \mathrm{C}$ & $1.9^{\circ} \mathrm{C}$ & $2.3^{\circ} \mathrm{C}$ \\
\hline $350^{\circ} \mathrm{C}$ & $0.8^{\circ} \mathrm{C}$ & $1.4^{\circ} \mathrm{C}$ & $1.9^{\circ} \mathrm{C}$ & $2.4^{\circ} \mathrm{C}$ \\
\hline $400^{\circ} \mathrm{C}$ & $0.8^{\circ} \mathrm{C}$ & $1.4^{\circ} \mathrm{C}$ & $1.9^{\circ} \mathrm{C}$ & $2.3^{\circ} \mathrm{C}$ \\
\hline & & & & \\
\hline
\end{tabular}




\subsection{BWR Assembly Geometries}

\subsubsection{Wooton-Epstein for 9x9 Array}

For this evaluation, the same material properties, assembly dimensions, and heat peaking factor were assumed with the Wooton-Epstein relation that were used in the discrete BWR SNF model in previous sections. Table 5.2-1. summarizes the peak cladding results of the Wooton-Epstein calculation and Table 5.2-2 provides the calculated cladding-to-basket temperature drops $(\Delta T)$. Details of this calculation can be found in the supporting BWR design analysis. ${ }^{[51]}$

The values presented in Tables 5.2-1 and 5.2-2 are those which would be reported for any 9x9 BWR SNF assembly for the corresponding conditions (i.e., basket temperature, decay heat powers, and material emissivity values). The Wooton-Epstein correlation does not contain any terms which account for a channel, water rod positions in the central part of the BWR SNF assembly, or part length fuel rods. Thus, this calculation need be performed only once for the $9 \times 9$ array, and this set of temperatures will be compared to all of the $9 \times 9$ BWR SNF assembly configurations analyzed in Section 4.

Table 5.2-1. Peak Cladding Temperatures, Wooton-Epstein Correlation (9x9)

\begin{tabular}{||c||c|c|c|c|c|c||}
\hline \hline \multirow{2}{*}{$\begin{array}{c}\text { Basket Wall } \\
\text { Temperature }\end{array}$} & \multicolumn{6}{|c||}{ Assembly Heat Load } \\
\cline { 2 - 7 } & 100 watts & 200 watts & 300 watts & 400 watts & 500 watts & 600 watts \\
\hline \hline $25^{\circ} \mathrm{C}$ & $41^{\circ} \mathrm{C}$ & $53^{\circ} \mathrm{C}$ & $64^{\circ} \mathrm{C}$ & $74^{\circ} \mathrm{C}$ & $83^{\circ} \mathrm{C}$ & $91{ }^{\circ} \mathrm{C}$ \\
\hline $50^{\circ} \mathrm{C}$ & $65^{\circ} \mathrm{C}$ & $76^{\circ} \mathrm{C}$ & $87^{\circ} \mathrm{C}$ & $96^{\circ} \mathrm{C}$ & $104^{\circ} \mathrm{C}$ & $113^{\circ} \mathrm{C}$ \\
\hline $100^{\circ} \mathrm{C}$ & $113^{\circ} \mathrm{C}$ & $123^{\circ} \mathrm{C}$ & $132^{\circ} \mathrm{C}$ & $140^{\circ} \mathrm{C}$ & $148^{\circ} \mathrm{C}$ & $155^{\circ} \mathrm{C}$ \\
\hline $150^{\circ} \mathrm{C}$ & $160^{\circ} \mathrm{C}$ & $169^{\circ} \mathrm{C}$ & $177^{\circ} \mathrm{C}$ & $184^{\circ} \mathrm{C}$ & $191^{\circ} \mathrm{C}$ & $198^{\circ} \mathrm{C}$ \\
\hline $200^{\circ} \mathrm{C}$ & $209^{\circ} \mathrm{C}$ & $216^{\circ} \mathrm{C}$ & $223^{\circ} \mathrm{C}$ & $229^{\circ} \mathrm{C}$ & $235^{\circ} \mathrm{C}$ & $241^{\circ} \mathrm{C}$ \\
\hline $250^{\circ} \mathrm{C}$ & $257^{\circ} \mathrm{C}$ & $263^{\circ} \mathrm{C}$ & $269^{\circ} \mathrm{C}$ & $274^{\circ} \mathrm{C}$ & $279^{\circ} \mathrm{C}$ & $284^{\circ} \mathrm{C}$ \\
\hline $300^{\circ} \mathrm{C}$ & $306^{\circ} \mathrm{C}$ & $311^{\circ} \mathrm{C}$ & $315^{\circ} \mathrm{C}$ & $320^{\circ} \mathrm{C}$ & $325^{\circ} \mathrm{C}$ & $329^{\circ} \mathrm{C}$ \\
\hline $350^{\circ} \mathrm{C}$ & $355^{\circ} \mathrm{C}$ & $359^{\circ} \mathrm{C}$ & $363^{\circ} \mathrm{C}$ & $367^{\circ} \mathrm{C}$ & $371^{\circ} \mathrm{C}$ & $374^{\circ} \mathrm{C}$ \\
\hline $400^{\circ} \mathrm{C}$ & $404^{\circ} \mathrm{C}$ & $407^{\circ} \mathrm{C}$ & $411^{\circ} \mathrm{C}$ & $414^{\circ} \mathrm{C}$ & $417^{\circ} \mathrm{C}$ & $420^{\circ} \mathrm{C}$ \\
\hline
\end{tabular}


Table 5.2-2. Cladding-to-Basket Delta T, Wooton-Epstein Correlation (9x9)

\begin{tabular}{||c||c|c|c|c|c|c||}
\hline \multirow{2}{*}{\begin{tabular}{|} 
Basket Wall \\
Temperature
\end{tabular}} & \multicolumn{6}{|c||}{ Assembly Heat Load } \\
\cline { 2 - 7 } & 100 watts & 200 watts & 300 watts & 400 watts & 500 watts & 600 watts \\
\hline \hline $25^{\circ} \mathrm{C}$ & $16^{\circ} \mathrm{C}$ & $28^{\circ} \mathrm{C}$ & $39^{\circ} \mathrm{C}$ & $49^{\circ} \mathrm{C}$ & $58^{\circ} \mathrm{C}$ & $66^{\circ} \mathrm{C}$ \\
\hline $50^{\circ} \mathrm{C}$ & $15^{\circ} \mathrm{C}$ & $26^{\circ} \mathrm{C}$ & $37^{\circ} \mathrm{C}$ & $46^{\circ} \mathrm{C}$ & $54^{\circ} \mathrm{C}$ & $63^{\circ} \mathrm{C}$ \\
\hline $100^{\circ} \mathrm{C}$ & $13^{\circ} \mathrm{C}$ & $23^{\circ} \mathrm{C}$ & $32^{\circ} \mathrm{C}$ & $40^{\circ} \mathrm{C}$ & $48^{\circ} \mathrm{C}$ & $55^{\circ} \mathrm{C}$ \\
\hline $150^{\circ} \mathrm{C}$ & $10^{\circ} \mathrm{C}$ & $19^{\circ} \mathrm{C}$ & $27^{\circ} \mathrm{C}$ & $34^{\circ} \mathrm{C}$ & $41^{\circ} \mathrm{C}$ & $48^{\circ} \mathrm{C}$ \\
\hline $200^{\circ} \mathrm{C}$ & $9{ }^{\circ} \mathrm{C}$ & $16^{\circ} \mathrm{C}$ & $23^{\circ} \mathrm{C}$ & $29^{\circ} \mathrm{C}$ & $35^{\circ} \mathrm{C}$ & $41^{\circ} \mathrm{C}$ \\
\hline $250^{\circ} \mathrm{C}$ & $7{ }^{\circ} \mathrm{C}$ & $13^{\circ} \mathrm{C}$ & $19^{\circ} \mathrm{C}$ & $24^{\circ} \mathrm{C}$ & $29^{\circ} \mathrm{C}$ & $34^{\circ} \mathrm{C}$ \\
\hline $300^{\circ} \mathrm{C}$ & $6^{\circ} \mathrm{C}$ & $11^{\circ} \mathrm{C}$ & $15^{\circ} \mathrm{C}$ & $20^{\circ} \mathrm{C}$ & $25^{\circ} \mathrm{C}$ & $29^{\circ} \mathrm{C}$ \\
\hline $350^{\circ} \mathrm{C}$ & $5^{\circ} \mathrm{C}$ & $9{ }^{\circ} \mathrm{C}$ & $13^{\circ} \mathrm{C}$ & $17^{\circ} \mathrm{C}$ & $21^{\circ} \mathrm{C}$ & $24{ }^{\circ} \mathrm{C}$ \\
\hline $400^{\circ} \mathrm{C}$ & $4{ }^{\circ} \mathrm{C}$ & $77^{\circ} \mathrm{C}$ & $11^{\circ} \mathrm{C}$ & $14^{\circ} \mathrm{C}$ & $17^{\circ} \mathrm{C}$ & $20^{\circ} \mathrm{C}$ \\
\hline
\end{tabular}

As expected, the Wooton-Epstein correlation over-predicts peak temperatures compared to the discrete BWR SNF models presented in Section 4 for the helium fill gas cases. However, for the vacuum, nitrogen, and argon cases the Wooton-Epstein correlation is not necessarily conservative. Table 5.2-3 provides a peak temperature comparison between the Wooton-Epstein results and peak temperatures predicted by the 9x9 BWR SNF assembly model with nitrogen fill gas (nitrogen is similar air). Wooton-Epstein is seen to be roughly equivalent to the assembly model with nitrogen at higher temperatures, but is somewhat nonconservative at temperatures of $200^{\circ} \mathrm{C}$ and less. This is due to the fact that the Wooton-Epstein correlation was developed from experimental data based upon air with convection and radiation heat transfer in a $17 \times 18$ rod array. The discrete SNF models for the vacuum, nitrogen, and argon do not include the convection heat transfer mode and the vacuum case does not have the conduction heat transfer mode as well. However, the same temperature trends with heat load and basket wall temperature variations are observed with the Wooton-Epstein correlation predicted peak cladding temperatures as with the discrete SNF model.

The Wooton-Epstein correlation exhibited similar behavior and trending (compared to the SNF models) for the cladding-to-basket temperature drop. The temperature drop $(\Delta T)$ decreased with increasing absolute temperature, and increased with assembly heat load. For each case with helium fill gas, the $\Delta \mathrm{T}$ was larger than predicted by the discrete BWR SNF model. 
Spent Nuclear Fuel Effective Thermal Conductivity Report

DI: BBA000000-01717-5705-00010 REV 00

Page 76 of 154

Table 5.2-3. Peak Temperature Difference (Wooton-Epstein vs. 9x9 BWR in Nitrogen)

\begin{tabular}{||c||c|c|c|c|c|c||}
\hline \hline \multirow{2}{*}{$\begin{array}{c}\text { Basket Wall } \\
\text { Temperature }\end{array}$} & \multicolumn{7}{|c||}{ Assembly Heat Load } \\
\cline { 2 - 7 } & 100 watts & 200 watts & 300 watts & 400 watts & 500 watts & 600 watts \\
\hline \hline $25^{\circ} \mathrm{C}$ & $-5.6^{\circ} \mathrm{C}$ & $-12.6^{\circ} \mathrm{C}$ & $-19.0^{\circ} \mathrm{C}$ & $-24.7^{\circ} \mathrm{C}$ & $-29.6^{\circ} \mathrm{C}$ & $-33.9^{\circ} \mathrm{C}$ \\
\hline $500^{\circ} \mathrm{C}$ & $-3.6^{\circ} \mathrm{C}$ & $-8.9^{\circ} \mathrm{C}$ & $-13.9^{\circ} \mathrm{C}$ & $-18.5^{\circ} \mathrm{C}$ & $-22.5^{\circ} \mathrm{C}$ & $-26.2^{\circ} \mathrm{C}$ \\
\hline $100^{\circ} \mathrm{C}$ & $-1.1^{\circ} \mathrm{C}$ & $-3.8^{\circ} \mathrm{C}$ & $-6.6^{\circ} \mathrm{C}$ & $-9.4^{\circ} \mathrm{C}$ & $-12.1^{\circ} \mathrm{C}$ & $-14.5^{\circ} \mathrm{C}$ \\
\hline $150^{\circ} \mathrm{C}$ & $0.1^{\circ} \mathrm{C}$ & $-1.1^{\circ} \mathrm{C}$ & $-2.5^{\circ} \mathrm{C}$ & $-4.1^{\circ} \mathrm{C}$ & $-5.7^{\circ} \mathrm{C}$ & $-7.2^{\circ} \mathrm{C}$ \\
\hline $200^{\circ} \mathrm{C}$ & $0.6^{\circ} \mathrm{C}$ & $0.2^{\circ} \mathrm{C}$ & $-0.4^{\circ} \mathrm{C}$ & $-1.1^{\circ} \mathrm{C}$ & $-1.9^{\circ} \mathrm{C}$ & $-2.8^{\circ} \mathrm{C}$ \\
\hline $250^{\circ} \mathrm{C}$ & $0.7^{\circ} \mathrm{C}$ & $0.8^{\circ} \mathrm{C}$ & $0.7^{\circ} \mathrm{C}$ & $0.4^{\circ} \mathrm{C}$ & $0.0^{\circ} \mathrm{C}$ & $-0.4^{\circ} \mathrm{C}$ \\
\hline $300^{\circ} \mathrm{C}$ & $0.7^{\circ} \mathrm{C}$ & $0.9^{\circ} \mathrm{C}$ & $1.1^{\circ} \mathrm{C}$ & $1.0^{\circ} \mathrm{C}$ & $1.0^{\circ} \mathrm{C}$ & $0.8^{\circ} \mathrm{C}$ \\
\hline $350^{\circ} \mathrm{C}$ & $0.6^{\circ} \mathrm{C}$ & $0.9^{\circ} \mathrm{C}$ & $1.1^{\circ} \mathrm{C}$ & $1.2^{\circ} \mathrm{C}$ & $1.3^{\circ} \mathrm{C}$ & $1.3^{\circ} \mathrm{C}$ \\
\hline $400^{\circ} \mathrm{C}$ & $0.5^{\circ} \mathrm{C}$ & $0.8^{\circ} \mathrm{C}$ & $1.0^{\circ} \mathrm{C}$ & $1.2^{\circ} \mathrm{C}$ & $1.3^{\circ} \mathrm{C}$ & $1.4^{\circ} \mathrm{C}$ \\
\hline
\end{tabular}

\subsubsection{Wooton-Epstein for $8 \times 8$ Array}

The Wooton-Epstein correlation was also evaluated for the $8 \times 8$ BWR SNF assembly. ${ }^{[50]}$ Temperature results were similar to those for the $9 \times 9$ assembly and the differences are listed in Table 5.2-4. Generally the $8 \times 8$ assembly resulted in lower peak cladding temperatures; however, the difference was only as much as about $2.3^{\circ} \mathrm{C}$. This result indicates that the correlation is not sensitive to small variations in the number of rods in the assembly and that the results for the $9 \times 9$ array are representative of this temperature prediction method for BWR assemblies.

Table 5.2-4. Peak Temperature Difference (Wooton-Epstein 9x9 vs. 8x8)

\begin{tabular}{||c||c|c|c|c|c|c||}
\hline \hline \multirow{2}{*}{$\begin{array}{c}\text { Basket Wall } \\
\text { Temperature }\end{array}$} & \multicolumn{5}{|c||}{ Assembly Heat Load } \\
\cline { 2 - 7 } & 100 watts & 200 watts & 300 watts & 400 watts & 500 watts & 600 watts \\
\hline \hline $25{ }^{\circ} \mathrm{C}$ & $0.5^{\circ} \mathrm{C}$ & $0.8^{\circ} \mathrm{C}$ & $1.1^{\circ} \mathrm{C}$ & $1.3^{\circ} \mathrm{C}$ & $1.5^{\circ} \mathrm{C}$ & $1.7^{\circ} \mathrm{C}$ \\
\hline $50^{\circ} \mathrm{C}$ & $0.6^{\circ} \mathrm{C}$ & $0.9^{\circ} \mathrm{C}$ & $1.2^{\circ} \mathrm{C}$ & $1.5^{\circ} \mathrm{C}$ & $1.7^{\circ} \mathrm{C}$ & $1.9^{\circ} \mathrm{C}$ \\
\hline $100^{\circ} \mathrm{C}$ & $0.6^{\circ} \mathrm{C}$ & $1.0^{\circ} \mathrm{C}$ & $1.4^{\circ} \mathrm{C}$ & $1.6^{\circ} \mathrm{C}$ & $1.9^{\circ} \mathrm{C}$ & $2.2^{\circ} \mathrm{C}$ \\
\hline $150^{\circ} \mathrm{C}$ & $0.6^{\circ} \mathrm{C}$ & $1.1^{\circ} \mathrm{C}$ & $1.4^{\circ} \mathrm{C}$ & $1.7^{\circ} \mathrm{C}$ & $2.0^{\circ} \mathrm{C}$ & $2.3^{\circ} \mathrm{C}$ \\
\hline $200^{\circ} \mathrm{C}$ & $0.6^{\circ} \mathrm{C}$ & $1.0^{\circ} \mathrm{C}$ & $1.4^{\circ} \mathrm{C}$ & $1.7^{\circ} \mathrm{C}$ & $2.0^{\circ} \mathrm{C}$ & $2.3^{\circ} \mathrm{C}$ \\
\hline $250^{\circ} \mathrm{C}$ & $0.5^{\circ} \mathrm{C}$ & $0.9^{\circ} \mathrm{C}$ & $1.3^{\circ} \mathrm{C}$ & $1.6^{\circ} \mathrm{C}$ & $1.9^{\circ} \mathrm{C}$ & $2.2^{\circ} \mathrm{C}$ \\
\hline $300^{\circ} \mathrm{C}$ & $0.5^{\circ} \mathrm{C}$ & $0.8^{\circ} \mathrm{C}$ & $1.2^{\circ} \mathrm{C}$ & $1.5^{\circ} \mathrm{C}$ & $1.8^{\circ} \mathrm{C}$ & $2.0^{\circ} \mathrm{C}$ \\
\hline $350^{\circ} \mathrm{C}$ & $0.4^{\circ} \mathrm{C}$ & $0.7^{\circ} \mathrm{C}$ & $1.0^{\circ} \mathrm{C}$ & $1.3^{\circ} \mathrm{C}$ & $1.6^{\circ} \mathrm{C}$ & $1.9^{\circ} \mathrm{C}$ \\
\hline $400^{\circ} \mathrm{C}$ & $0.3^{\circ} \mathrm{C}$ & $0.6^{\circ} \mathrm{C}$ & $0.9^{\circ} \mathrm{C}$ & $1.2^{\circ} \mathrm{C}$ & $1.4^{\circ} \mathrm{C}$ & $1.6^{\circ} \mathrm{C}$ \\
\hline
\end{tabular}




\subsubsection{Wooton-Epstein for $7 \times 7$ Array}

To confirm the trending above, the Wooton-Epstein correlation was also evaluated for the $7 \times 7$ BWR SNF assembly. ${ }^{[49]}$ Temperature results were similar to those for the $9 \times 9$ assembly and the differences are listed in Table 5.2-5. Generally the $7 \times 7$ assembly resulted in very similar temperatures to those for the 8x8 array. Again, this result indicates that the Wooton-Epstein correlation is not sensitive to small variations in the number of rods in the assembly and that the results for the $9 \times 9$ array are representative of this temperature prediction method for BWR assemblies.

Table 5.2-5. Peak Temperature Difference (Wooton-Epstein 9x9 vs. 7x7)

\begin{tabular}{||c||c|c|c|c|c|c||}
\hline \multirow{2}{*}{\begin{tabular}{|} 
Basket Wall \\
Temperature
\end{tabular}} & \multicolumn{6}{|c||}{ Assembly Heat Load } \\
\cline { 2 - 7 } & 100 watts & 200 watts & 300 watts & 400 watts & 500 watts & 600 watts \\
\hline \hline $25^{\circ} \mathrm{C}$ & $0.5^{\circ} \mathrm{C}$ & $0.7^{\circ} \mathrm{C}$ & $0.9^{\circ} \mathrm{C}$ & $1.0^{\circ} \mathrm{C}$ & $1.2^{\circ} \mathrm{C}$ & $1.3^{\circ} \mathrm{C}$ \\
\hline $50^{\circ} \mathrm{C}$ & $0.6^{\circ} \mathrm{C}$ & $0.9^{\circ} \mathrm{C}$ & $1.1^{\circ} \mathrm{C}$ & $1.3^{\circ} \mathrm{C}$ & $1.5^{\circ} \mathrm{C}$ & $1.7^{\circ} \mathrm{C}$ \\
\hline $100^{\circ} \mathrm{C}$ & $0.8^{\circ} \mathrm{C}$ & $1.2^{\circ} \mathrm{C}$ & $1.5^{\circ} \mathrm{C}$ & $1.8^{\circ} \mathrm{C}$ & $2.1^{\circ} \mathrm{C}$ & $2.4^{\circ} \mathrm{C}$ \\
\hline $150^{\circ} \mathrm{C}$ & $0.8^{\circ} \mathrm{C}$ & $1.3^{\circ} \mathrm{C}$ & $1.8^{\circ} \mathrm{C}$ & $2.1^{\circ} \mathrm{C}$ & $2.5^{\circ} \mathrm{C}$ & $2.8^{\circ} \mathrm{C}$ \\
\hline $200^{\circ} \mathrm{C}$ & $0.8^{\circ} \mathrm{C}$ & $1.3^{\circ} \mathrm{C}$ & $1.8^{\circ} \mathrm{C}$ & $2.2^{\circ} \mathrm{C}$ & $2.6^{\circ} \mathrm{C}$ & $3.0^{\circ} \mathrm{C}$ \\
\hline $250^{\circ} \mathrm{C}$ & $0.7^{\circ} \mathrm{C}$ & $1.3^{\circ} \mathrm{C}$ & $1.7^{\circ} \mathrm{C}$ & $2.2^{\circ} \mathrm{C}$ & $2.6^{\circ} \mathrm{C}$ & $2.9^{\circ} \mathrm{C}$ \\
\hline $300^{\circ} \mathrm{C}$ & $0.6^{\circ} \mathrm{C}$ & $1.1^{\circ} \mathrm{C}$ & $1.6^{\circ} \mathrm{C}$ & $2.0^{\circ} \mathrm{C}$ & $2.4^{\circ} \mathrm{C}$ & $2.8^{\circ} \mathrm{C}$ \\
\hline $350^{\circ} \mathrm{C}$ & $0.5^{\circ} \mathrm{C}$ & $1.0^{\circ} \mathrm{C}$ & $1.4^{\circ} \mathrm{C}$ & $1.8^{\circ} \mathrm{C}$ & $2.2^{\circ} \mathrm{C}$ & $2.6^{\circ} \mathrm{C}$ \\
\hline $400^{\circ} \mathrm{C}$ & $0.5^{\circ} \mathrm{C}$ & $0.9^{\circ} \mathrm{C}$ & $1.3^{\circ} \mathrm{C}$ & $1.6^{\circ} \mathrm{C}$ & $2.0^{\circ} \mathrm{C}$ & $2.3^{\circ} \mathrm{C}$ \\
\hline
\end{tabular}




\section{SNF Effective Thermal Conductivities}

In previous waste package thermal models, ${ }^{[28,29,35,36]}$ the SNF assembly is represented by a 2-D solid square cross section with smeared (distributed) material properties. While the density and heat capacity can be calculated based on a weighted average of the materials present, the thermal conductivity of the SNF assembly area must take into account convection, conduction, and radiation heat transfer across the assembly. Some work to this effect has been done for consolidated assemblies; however, information is sketchy for intact assemblies. The final design reports for the GA-4 and GA-9 truck casks ${ }^{[33,34]}$ give relations (repeated here as Equations 6.0-1 and 6.0-2) for PWR and BWR SNF effective thermal conductivities ( $\mathrm{k}$ in Btu/hr$\left.\cdot{ }^{\circ} \cdot{ }^{\circ} \mathrm{F}\right)$ as a function of the assumed helium fill gas thermal conductivity $\left(\mathrm{k}_{\mathrm{He}}\right)^{[33]}$ and of temperature $\left({ }^{\circ} \mathrm{R}\right)$. Evaluating the relations result in conductivities ranging from $0.399 \mathrm{~W} / \mathrm{m} \cdot \mathrm{K}\left(\right.$ at $0{ }^{\circ} \mathrm{C}$ ) to $1.316 \mathrm{~W} / \mathrm{m} \cdot \mathrm{K}$ (at $400^{\circ} \mathrm{C}$ ) for PWR assemblies and $0.418 \mathrm{~W} / \mathrm{m} \cdot \mathrm{K}\left(\right.$ at $0^{\circ} \mathrm{C}$ ) to $1.606 \mathrm{~W} / \mathrm{m} \cdot \mathrm{K}$ (at $400^{\circ} \mathrm{C}$ ) for BWR assemblies.

$$
\begin{aligned}
& k_{x}=k_{y}=2.5 k_{H e}+1.755 \times 10^{-11} T^{3} \\
& k_{x}=k_{y}=2.5 k_{H e}+2.536 \times 10^{-11} T^{3}
\end{aligned}
$$

(Equation 6.0-1)

(Equation 6.0-2)

Using a methodology similar to that of this report, the safety analysis for the NAC Storable Transport Cask ${ }^{[37]}$ calculated effective thermal conductivities of $1.04 \mathrm{~W} / \mathrm{m} \cdot \mathrm{K}\left(0.05 \mathrm{Btu} / \mathrm{hr} \cdot \mathrm{in} \cdot{ }^{\circ} \mathrm{F}\right)$ and $0.62 \mathrm{~W} / \mathrm{m} \cdot \mathrm{K}\left(0.03 \mathrm{Btu} / \mathrm{hr} \cdot \mathrm{in}^{\circ}{ }^{\circ} \mathrm{F}\right)$ for a homogeneous PWR fuel assembly with fill gases of helium and air, respectively. However, the NAC work was performed only for a single temperature of around $315^{\circ} \mathrm{C}\left(600^{\circ} \mathrm{F}\right)$.

For a comparison to other SNF geometries, a consolidated assembly (in a vacuum) may have an effective thermal conductivity from 0.060 to $0.590 \mathrm{~W} / \mathrm{m} \cdot \mathrm{K}^{[39]}$ over the range 0 to $400^{\circ} \mathrm{C}$. These consolidated SNF values were used in several evaluations by Lawrence Livermore National Laboratory for consolidated SNF in borehole emplaced waste packages. ${ }^{[0,41]}$ Effective thermal conductivity relations have also been developed for experimental breeder reactor fuel. ${ }^{[42]}$ An attempt made to calculate an effective medium conductivity for PWR SNF using debris bed conductivity correlations ${ }^{[43]}$ resulted in a very conservative estimate of $0.127 \mathrm{~W} / \mathrm{m} \cdot \mathrm{K}$. As observed in the previous sections, a single value for an effective thermal conductivity is not sufficient due to the radiation induced nonlinearities present. 


\subsection{Effective Thermal Conductivity Development}

The purpose of the effective thermal conductivity is to relate the temperature drop of a homogeneous heat generating square to the temperature drop across an actual assembly. Given the heat load and temperature drop calculated with a discrete model of an SNF assembly, we wish to calculate here the effective thermal conductivity of the homogeneous heat-generating square. An analytical solution of the heat diffusion equation for a steady temperature in a rectangle with heat generation is given by Equation 5.5-6 in Carslaw and Jaeger. ${ }^{[44]}$ Since we are considering a square with isotropic thermal conductivity, $a=b$ and $k=1$ and Equation $5.5-6^{[44]}$ can be simplified to Equation 6.1-1 below.

$$
T(x, y)=\frac{q^{\prime \prime \prime}\left(a^{2}-x^{2}\right)}{2 k}-\frac{16 q^{\prime \prime \prime} a^{2}}{k \pi^{3}} \sum_{n=0}^{\infty} \frac{(-1)^{n} \cos [(2 n+1) \pi x / 2 a] \cosh [(2 n+1) \pi y / 2 a]}{(2 n+1)^{3} \cosh [(2 n+1) \pi / 2]}
$$

(Equation 6.1-1)

In Equation 6.1-1, $q^{\prime \prime \prime}$ is the volumetric heat generation, $k$ is the conductivity, and $a$ is one half of the basket cell width. We are interested in the maximum temperature, which occurs at $x=y=0$, therefore, Equation $6.1-1$ can be reduced to:

$$
T(0,0)=\frac{q^{\prime \prime \prime} a^{2}}{2 k}-\frac{16 q^{\prime \prime \prime} a^{2}}{k \pi^{3}} \sum_{n=0}^{\infty} \frac{(-1)^{n}}{(2 n+1)^{3} \cosh [(2 n+1) \pi / 2]}
$$

(Equation 6.1-2)

Because of the strong divergence of cosh, the sum converges quickly. Evaluating the sum, we find:

$$
T(0,0)=\frac{q^{\prime \prime \prime} a^{2}}{k}(0.2947)
$$

(Equation 6.1-3)

Assuming superposition (non-zero wall temperature $T_{s}$ ) and substituting $q^{\prime \prime \prime}=Q / 4 a^{2} L_{a}$ gives:

$$
T_{o}=\frac{Q}{4 L_{a} k}(0.2947)+T_{s}
$$

(Equation 6.1-4)

Finally, solving for an effective thermal conductivity $\left(k_{e}\right)$ results in Equation 6.1-5:

$$
k_{e}=\frac{Q}{4 L_{a}\left(T_{o}-T_{s}\right)}(0.2947)
$$

(Equation 6.1-5) 
Where:

$$
\begin{array}{ll}
Q & =\text { Assembly heat generation (watts) } \\
L_{a} & =\text { Assembly active length (meters) } \\
T_{o} & =\text { Center temperature (peak cladding }{ }^{\circ} \mathrm{C} \text { ) } \\
T_{s} & \text { = Surface temperature (basket wall }{ }^{\circ} \mathrm{C} \text { ) }
\end{array}
$$

As a reality check to Equation 6.1-5, an analytical solution for the effective thermal conductivity of a homogeneous heat generating cylinder (circular cross section) can be derived from Equation 3.52 of a standard heat transfer text. ${ }^{[11]}$ This equation for the temperature distribution of a homogeneous solid cylinder with volumetric heat generation $q^{\prime \prime \prime}$ and radius $r_{o}$ is repeated as Equation 6.1-6 below.

$$
T(r)=\frac{q^{\prime \prime \prime} r_{o}^{2}}{4 k}\left(1-\frac{r^{2}}{r_{o}^{2}}\right)+T_{s}
$$

(Equation 6.1-6)

Evaluating at $r=0$, substituting $q^{\prime \prime \prime}=Q / \pi r_{o}^{2} L_{a}$, evaluating $1 / \pi$ as 0.3183 , and solving for effective thermal conductivity $\left(k_{e}\right)$ results in Equation 6.1-7 which is very similar in form to Equation 6.1-5.

$$
k_{e}=\frac{Q}{4 L_{a}\left(T_{o}-T_{s}\right)}(0.3183)
$$

(Equation 6.1-7)

It can be concluded from a comparison of Equations 6.1-5 and 6.1-7 that a homogeneous heat generating square and a homogeneous heat generating cylinder (circle) would have only an 8 percent difference in their predicted effective thermal conductivities. However, this is of academic interest only, as the purpose of the derivation of Equation 6.1-7 is to confirm that the correct form was derived for Equation 6.1-5 which will be used in the following sections. 


\subsection{PWR Assembly Geometries}

Using the results of Section 4 and Equation 6.1-5, effective thermal conductivities can be derived for each assembly type, size, and fill environment over the range of basket wall temperatures and assembly heat loads considered. There are, however, two ways to present and subsequently use the results of the effective thermal conductivity determination. If the conductivity is defined as a function of basket temperature, it can be used to determine the peak cladding temperature if the SNF basket wall temperature and assembly heat load are known. However, if a finite element (such as ANSYS) or finite difference code is used to model the SNF assembly as a smeared heat source, the code will evaluate the temperature-dependent effective thermal conductivity at each individual node (element) temperature and not at the basket temperature. Therefore, a second presentation of effective thermal conductivities is provided with values based on the assembly median temperature for each solution case. This method is described in Section 6.2.2.

\subsubsection{Effective Conductivity for Known Basket Wall Temperatures}

Equation 6.1-5 was used to predict an effective thermal conductivity for each temperature and heat load evaluated. Using the assembly analysis results from Section 4 , the calculation was performed for the $17 \times 17,15 \times 15$, and 14x14 PWR arrays in each fill environment (helium, vacuum, nitrogen, and argon) and for the Wooton-Epstein results for the 17x17 PWR assembly (bounding the results for the $15 \times 15$ and $14 \times 14$ arrays). Details of the results are provided in the supporting PWR design analysis ${ }^{[48]}$ and summary results are provided here.

As expected, the effective thermal conductivity results are highly temperature-dependent for each assembly and fill environment; however, for the discrete SNF model results, there was little dependence on the assembly heat load (calculated values varied only slightly with heat load for the same basket temperature). This is contrasted to the Wooton-Epstein results where there was some dependence on heat load observed, though less evident than the temperature dependence.

Some thermal analysis codes are capable of solving with temperature-dependent material properties; however, very few can handle more than one dimension of nonlinearity in the properties. If the heat load dependence for the effective thermal conductivity can be shown to be small, then a more useful conductivity can be defined that is a function of temperature only. The results strongly suggest that the effective thermal conductivity is either weakly dependent upon heat load or is not dependent upon heat load at all. The reason for the slight heat load dependence observed is that radiation heat transfer at the center of the assembly is increased for higher heat loads. The efficiency of radiation heat transfer increases with increasing absolute temperature (due to the $\mathrm{T}^{4}$ term); therefore, the center of the assembly experiences higher absolute temperatures (for the same basket temperature) with higher heat loads and the heat transfer resistance at the center is disproportionally lower for higher heat loads. This effect is minor, however, and we can assume the effective thermal conductivities to be dependent upon basket wall temperature only. Thus, a temperature-dependent effective thermal conductivity can be determined for each SNF basket wall temperature by averaging the values over the heat loads for each basket temperature. This temperature-dependent conductivity could then be used to predict peak cladding temperatures given the basket wall temperature, the assembly heat load, and Equation 6.1-5. 
Figures 6.2-1, 6.2-2, 6.2-3, and 6.2-4 provide graphical comparisons of the average (over the four heat loads) effective thermal conductivity for each of the PWR assembly configurations in fill environments of helium, vacuum, nitrogen, and argon, respectively. For the vacuum cases (Figure 6.2-2), thermal radiation is the only heat transfer mechanism between the SNF rods and the basket wall. Therefore, the 17x17 PWR assembly (which has more layers of rods to confound thermal radiation) results in the most conservative effective thermal conductivity. Lower values of conductivity are conservative because they will result in the highest estimations of peak cladding temperature when used. Similarly, for fill gases of nitrogen and argon (Figures 6.2-3 and 6.2-4), where radiation heat transfer dominates gaseous conduction, the $17 \times 17$ array is the most conservative.

For helium (Figure 6.2-1), however, gaseous conduction plays an important role: reducing peak temperatures more in the $17 \times 17$ array than the $14 \times 14$ array at low temperatures. The $14 \times 14$ PWR assembly, which has over-sized guide tubes displacing a larger proportion of fuel rods and the shortest length, has a sufficiently higher heat load per fuel rod such that resulting peak temperatures were higher than those for the $17 \times 17$ and 15x15 arrays. As seen in Figure 6.2-1, effective thermal conductivities calculated from the $14 \times 14$ PWR SNF assembly results are more conservative than those for the $17 \times 17$ array for temperature less than $300^{\circ} \mathrm{C}$. Since this covers most of the normal operating range for an SNF container, the 14x14 array results are more conservative for the helium fill gas.

Average effective thermal conductivities calculated from the Wooton-Epstein results of Section 5 are also plotted for comparison in Figures 6.2-1, 6.2-2, 6.2-3, and 6.2-4. The most conservative results (those for the $17 \times 17$ PWR array) were chosen for comparison. For assemblies with helium fill gas, the Wooton-Epstein correlation would result in significantly over-predicted peak cladding temperatures compared to using the effective thermal conductivity method. For the vacuum, nitrogen, and argon cases, however, Wooton-Epstein is seen to be nonconservative at low basket temperatures and over-conservative at high basket temperatures. Note that the Wooton-Epstein correlation was developed only for PWR-sized arrays with a fill gas of air (which is closest here to the nitrogen fill gas).

Table 6.2-1 summarizes the bounding results (based on basket wall temperature) for PWR assemblies. As discussed above, the $14 \times 14$ array was bounding for helium fill gas and the $17 \times 17$ array is bounding for vacuum, nitrogen, and argon. While the different PWR assembly designs resulted in very small differences (and can be bounded by one assembly array for each fill environment), results for different fill environments were significant. Therefore, the appropriate effective thermal conductivity should be chosen for use based on the expected fill environment for thermal evaluations of SNF containers. Comparisons between the fill environments are provided in Section 6.4.1. 


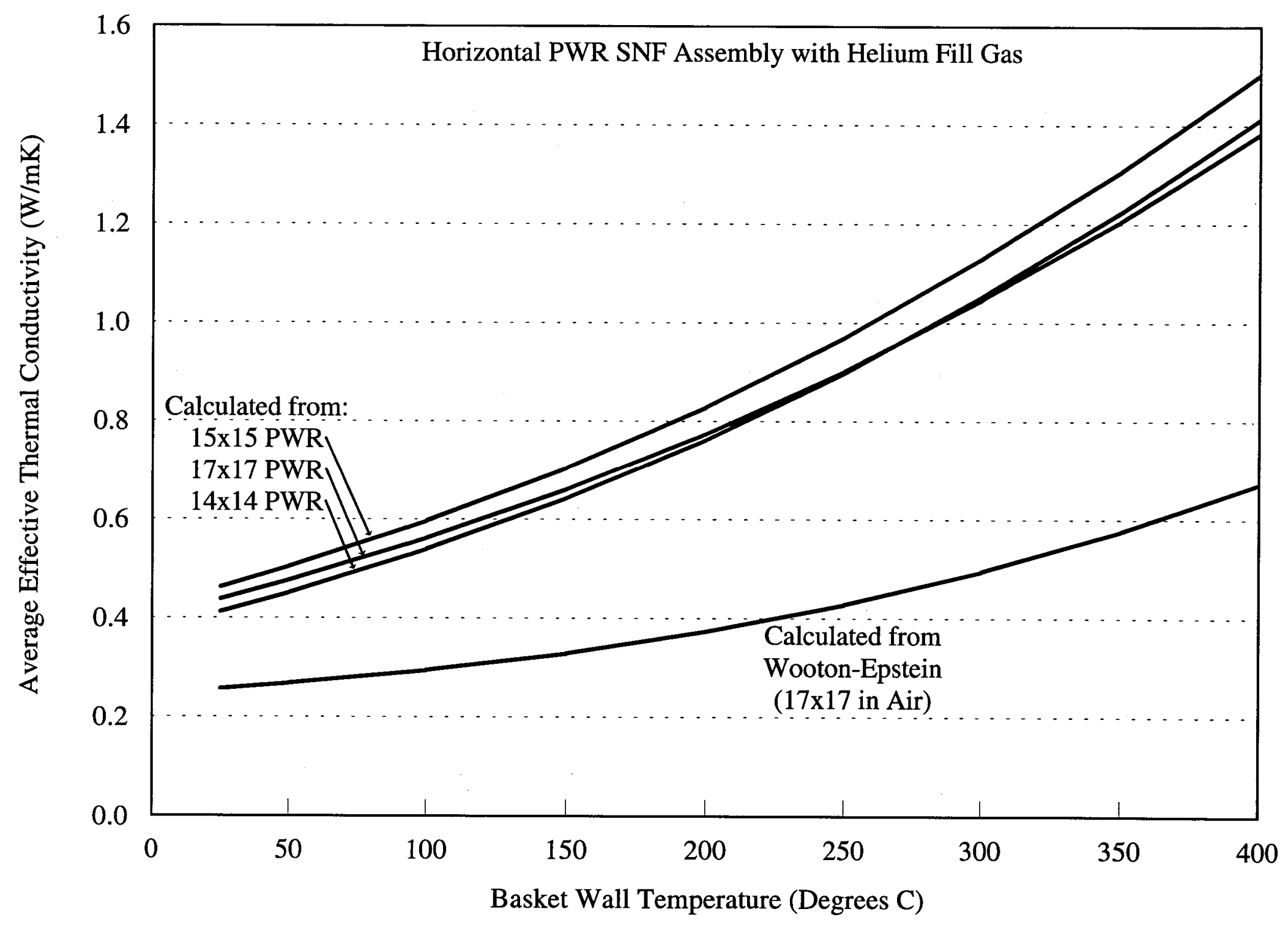

Figure 6.2-1. Average PWR Effective Thermal Conductivities for Helium 


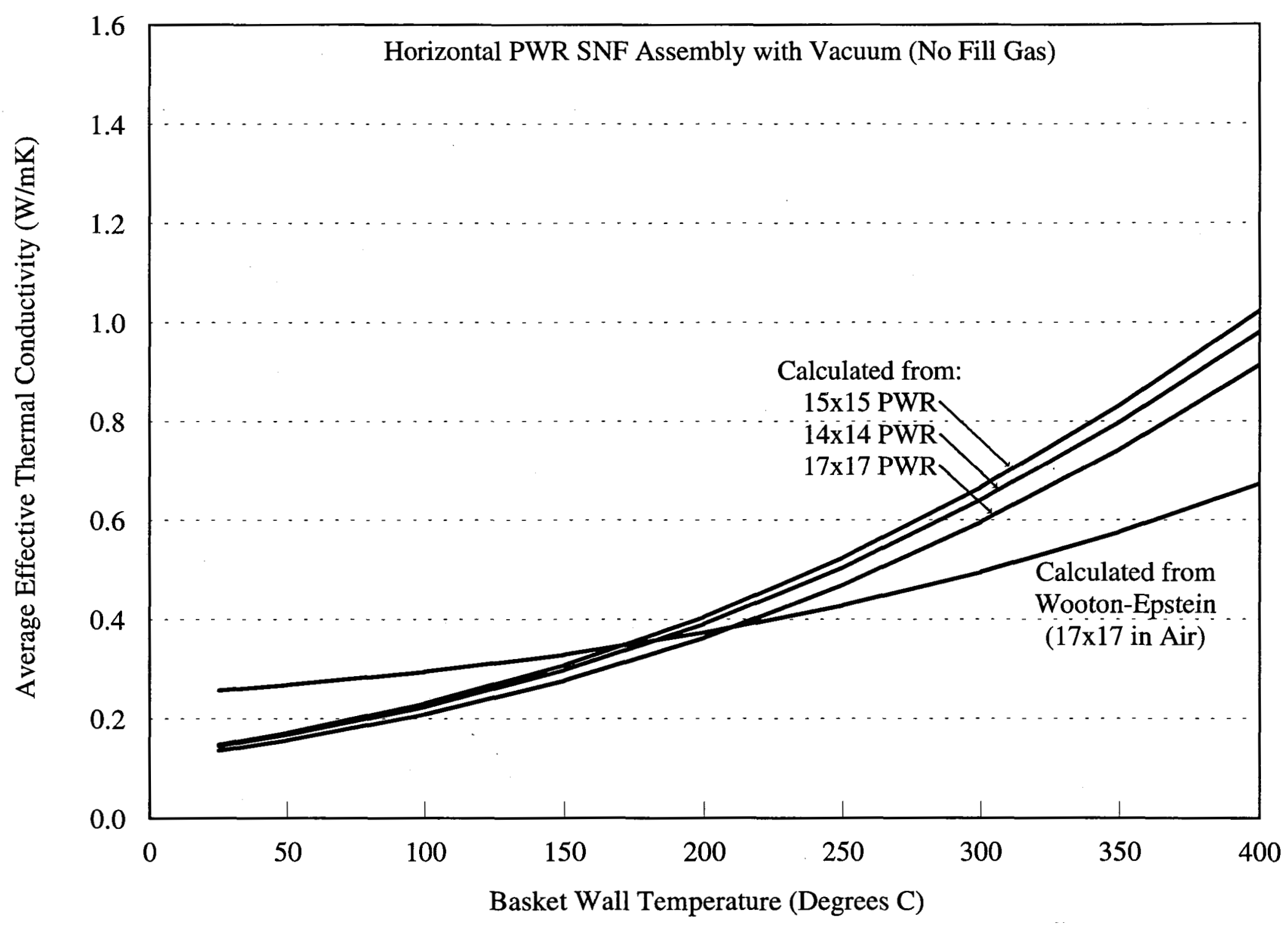

Figure 6.2-2. Average PWR Effective Thermal Conductivities for Vacuum 


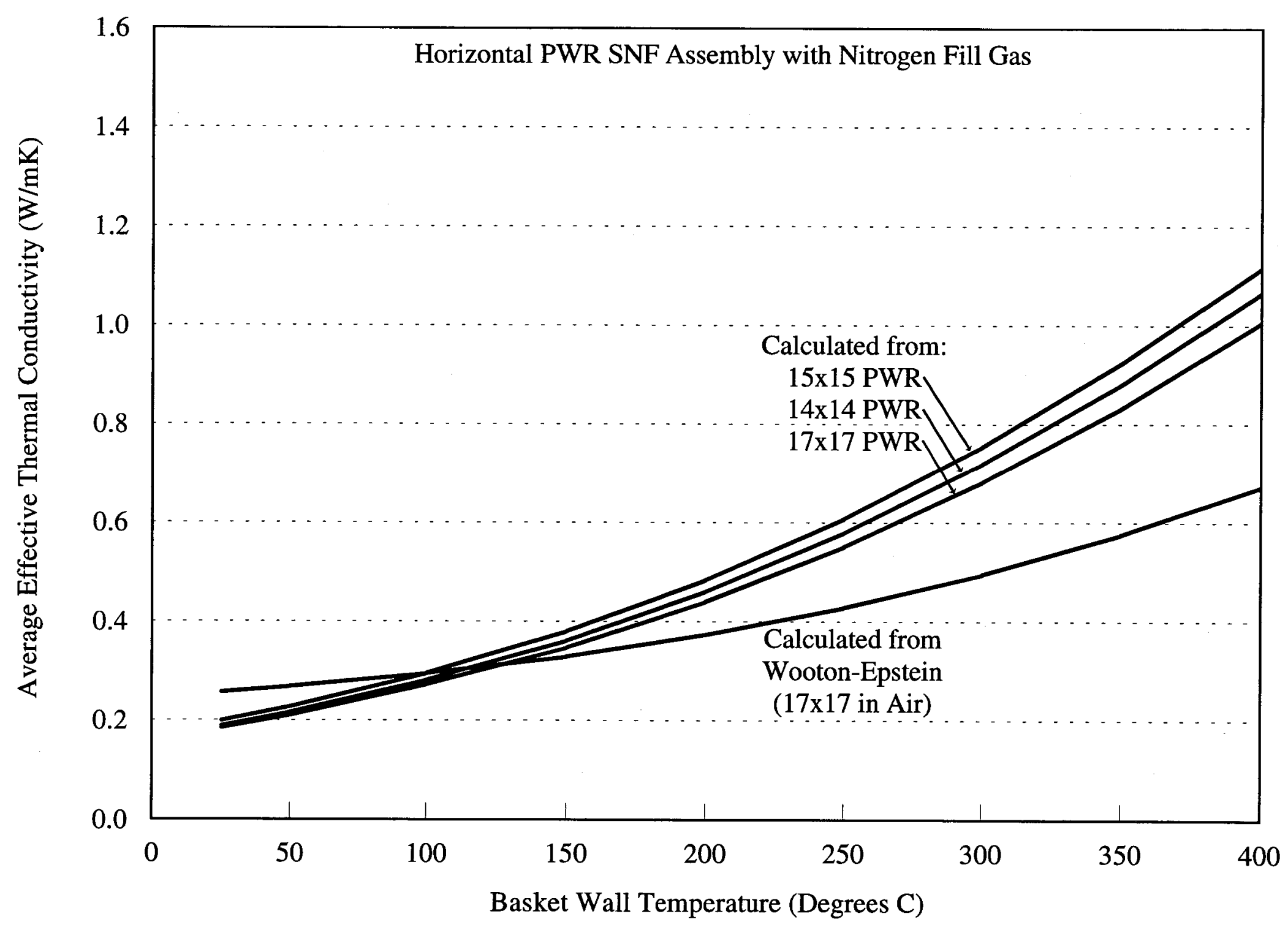

Figure 6.2-3. Average PWR Effective Thermal Conductivities for Nitrogen 


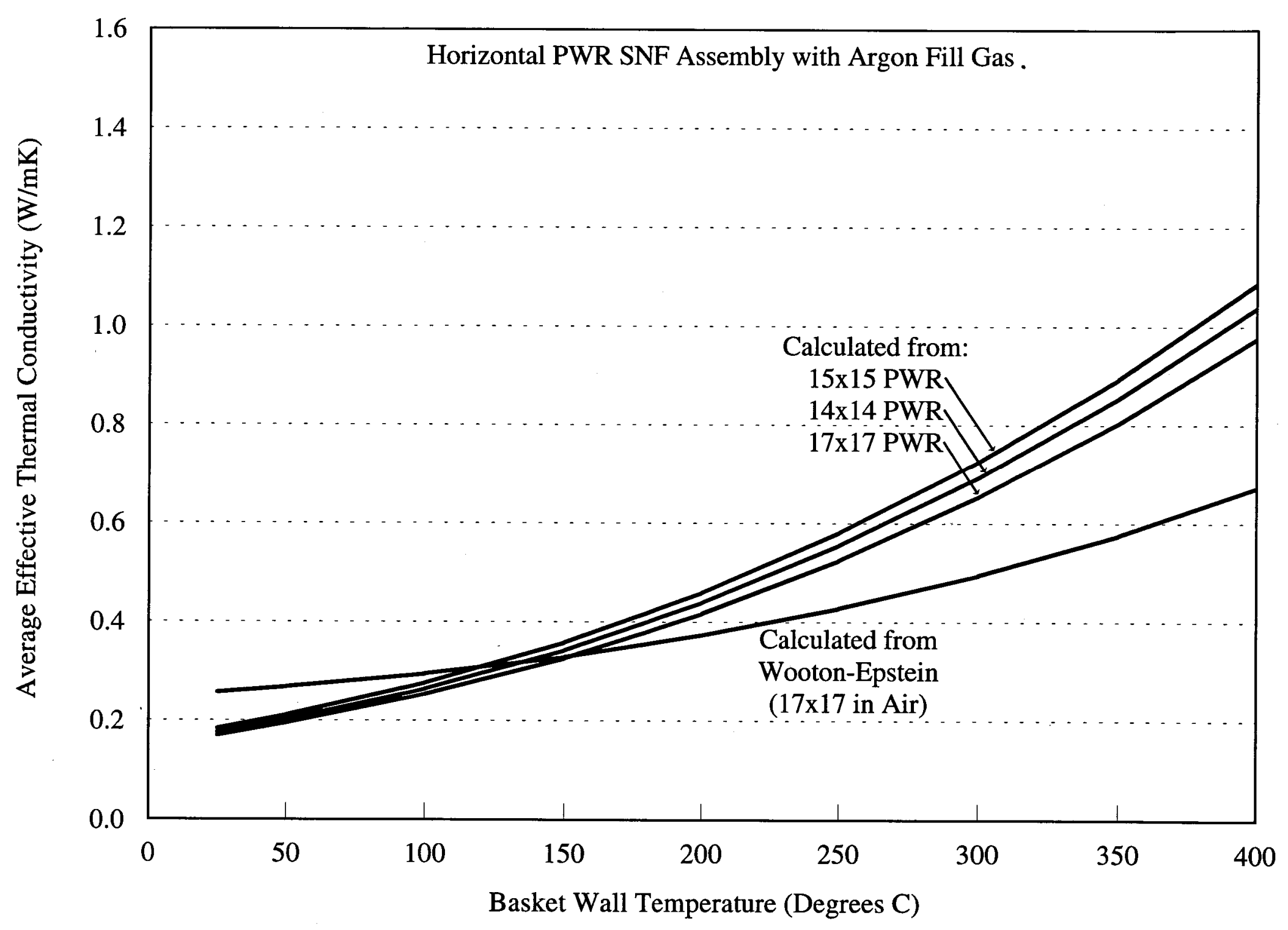

Figure 6.2-4. Average PWR Effective Thermal Conductivities for Argon

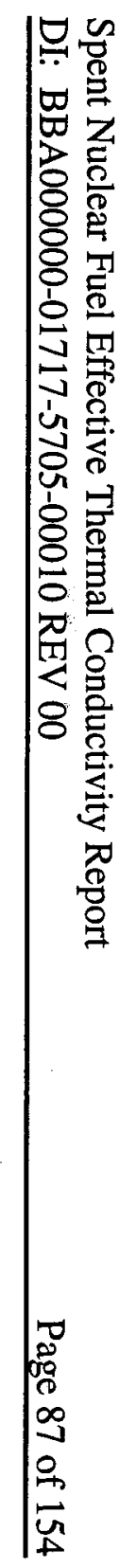


Table 6.2-1. Average Effective Conductivities for PWR SNF (Basket Wall Based)

\begin{tabular}{||c||c|c|c|c||}
\hline $\begin{array}{c}\text { Basket Wall } \\
\text { Temperature }\end{array}$ & $\begin{array}{c}\text { Average } \mathrm{k}_{\mathrm{e}} \\
(\mathrm{W} / \mathrm{m} \cdot \mathrm{K}) \\
14 \times 14 \text { Array } \\
\text { in Helium }\end{array}$ & $\begin{array}{c}\text { Average } \mathrm{k}_{\mathrm{e}} \\
(\mathrm{W} / \mathrm{m} \cdot \mathrm{K}) \\
17 \times 17 \text { Array } \\
\text { in Vacuum }\end{array}$ & $\begin{array}{c}\text { Average } \mathrm{k}_{\mathrm{e}} \\
(\mathrm{W} / \mathrm{m} \cdot \mathrm{K}) \\
17 \times 17 \text { Array } \\
\text { in Nitrogen }\end{array}$ & $\begin{array}{c}\text { Average } \mathrm{k}_{e} \\
(\mathrm{~W} / \mathrm{m} \cdot \mathrm{K}) \\
17 \times 17 \text { Array } \\
\text { in Argon }\end{array}$ \\
\hline \hline $25^{\circ} \mathrm{C}$ & 0.412 & 0.136 & 0.185 & 0.170 \\
\hline $50^{\circ} \mathrm{C}$ & 0.451 & 0.157 & 0.210 & 0.195 \\
\hline $100^{\circ} \mathrm{C}$ & 0.540 & 0.209 & 0.272 & 0.253 \\
\hline $150^{\circ} \mathrm{C}$ & 0.643 & 0.277 & 0.347 & 0.326 \\
\hline $200^{\circ} \mathrm{C}$ & 0.762 & 0.363 & 0.440 & 0.417 \\
\hline $250^{\circ} \mathrm{C}$ & 0.898 & 0.469 & 0.551 & 0.525 \\
\hline $300^{\circ} \mathrm{C}$ & 1.053 & 0.596 & 0.682 & 0.654 \\
\hline $350^{\circ} \mathrm{C}$ & 1.224 & 0.743 & 0.832 & 0.804 \\
\hline $400^{\circ} \mathrm{C}$ & 1.414 & 0.914 & 1.005 & 0.976 \\
\hline
\end{tabular}

\subsubsection{Effective Conductivity for Finite Element Analysis}

The PWR SNF effective thermal conductivity presented in Section 6.2.1 is an average thermal conductivity for determining peak cladding temperature given the basket wall temperature. However, finite element codes determine the material property values used for a node location based upon the node temperature, not an external temperature like a basket wall temperature. Also, the basket wall temperature is often being calculated by the finite element analysis as well and is not a known value before the analysis is run. If the thermal conductivity tables provided in Section 6.2.1 were to be used directly by a finite element code, the local node temperature, which is typically much higher than the basket wall temperature, would be used to determine the local conductivity (which would be somewhat higher than would be determined using the basket wall temperature). This will be true for every local node from the center of the SNF assembly to the basket wall. Thus, the average SNF material thermal conductivity determined by the finite element code will be higher for a given basket wall temperature and therefore would consistently under-predict the peak cladding temperature. This would be a consistently nonconservative bias for any use of the Section 6.2.1 thermal conductivity results with finite element codes.

Since finite element codes, such as ANSYS, are useful engineering design tools, it is very desirable to determine effective thermal conductivity which can be used accurately with finite element codes. The simplest method is to re-scale the data presented in Section 6.2.1 from a basket wall temperature basis to a temperature scale based on the assembly median temperature. The median temperature is defined here as the temperature halfway between the basket temperature and the calculated peak temperature for each data solution case $\left(\mathrm{T}_{\mathrm{m}}=\left[\mathrm{T}_{\text {basket }}+\mathrm{T}_{\text {peak }}\right] / 2\right)$. 
The use of an effective thermal conductivity determined with Equation 6.1-5 based on median temperature will allow a finite element code to over-predict the effective thermal conductivity on roughly half of the local nodes and under-predict the effective thermal conductivity on the remaining half of the local nodes. In this manner, the average SNF thermal conductivity for the global SNF assembly will be the same as the average effective thermal conductivity determined with the basket wall temperature and the Section 6.2.1 results. A second benefit to defining the conductivity as a function of median temperature is to eliminate the slight dependence on assembly heat load observed with the values based on basket wall temperature. In this case, the portions of the assembly experiencing higher than median temperatures (and the effects due to radiation heat transfer) are balanced by the portions of the assembly experiencing lower than median temperatures. This method based on median temperature was back checked as documented in Section 7.1 and benchmarked as documented in Sections 7.2 and 7.3.

Figures 6.2-5, 6.2-6, 6.2-7, and 6.2-8 provide graphical comparisons of the effective thermal conductivity (defined as a function of median temperature) for each of the PWR assembly configurations in fill environments of helium, vacuum, nitrogen, and argon, respectively. Again, for the vacuum cases (Figure 6.2-6), thermal radiation is the only heat transfer mechanism between the SNF rods and the basket wall. Therefore, the $17 \times 17$ PWR assembly (which has more layers of rods to confound thermal radiation) results in the most conservative effective thermal conductivity. Similarly for fill gases of nitrogen and argon (Figures 6.2-7 and 6.2-8), where radiation heat transfer dominates gaseous conduction, the $17 \times 17$ array is the most conservative.

As seen in the previous section, gaseous conduction plays an important role for helium (Figure 6.2-5): reducing peak temperatures more in the $17 \times 17$ array than the $14 \times 14$ array at low temperatures. Effective thermal conductivities calculated from the $14 \times 14$ PWR SNF assembly in helium results are more conservative than those for the $17 \times 17$ array for temperature less than $300^{\circ} \mathrm{C}$. Since this covers most of the normal operating range for an SNF container, the $14 \times 14$ array results are more conservative for the helium fill gas.

Effective thermal conductivities calculated from the Wooton-Epstein results of Section 5 are also plotted (as a function of median temperature) for comparison in Figures 6.2-5, 6.2-6, 6.2-7, and 6.28. Again, for assemblies with helium fill gas, the Wooton-Epstein correlation would result in significantly over-predicted peak cladding temperatures compared to using the effective thermal conductivity method. For the vacuum, nitrogen, and argon cases, however, Wooton-Epstein is seen to be nonconservative at low basket temperatures and over-conservative at high basket temperatures. Note that the Wooton-Epstein correlation was intended only for PWR-sized arrays with a fill gas of air (which is closest here to the nitrogen fill gas). 


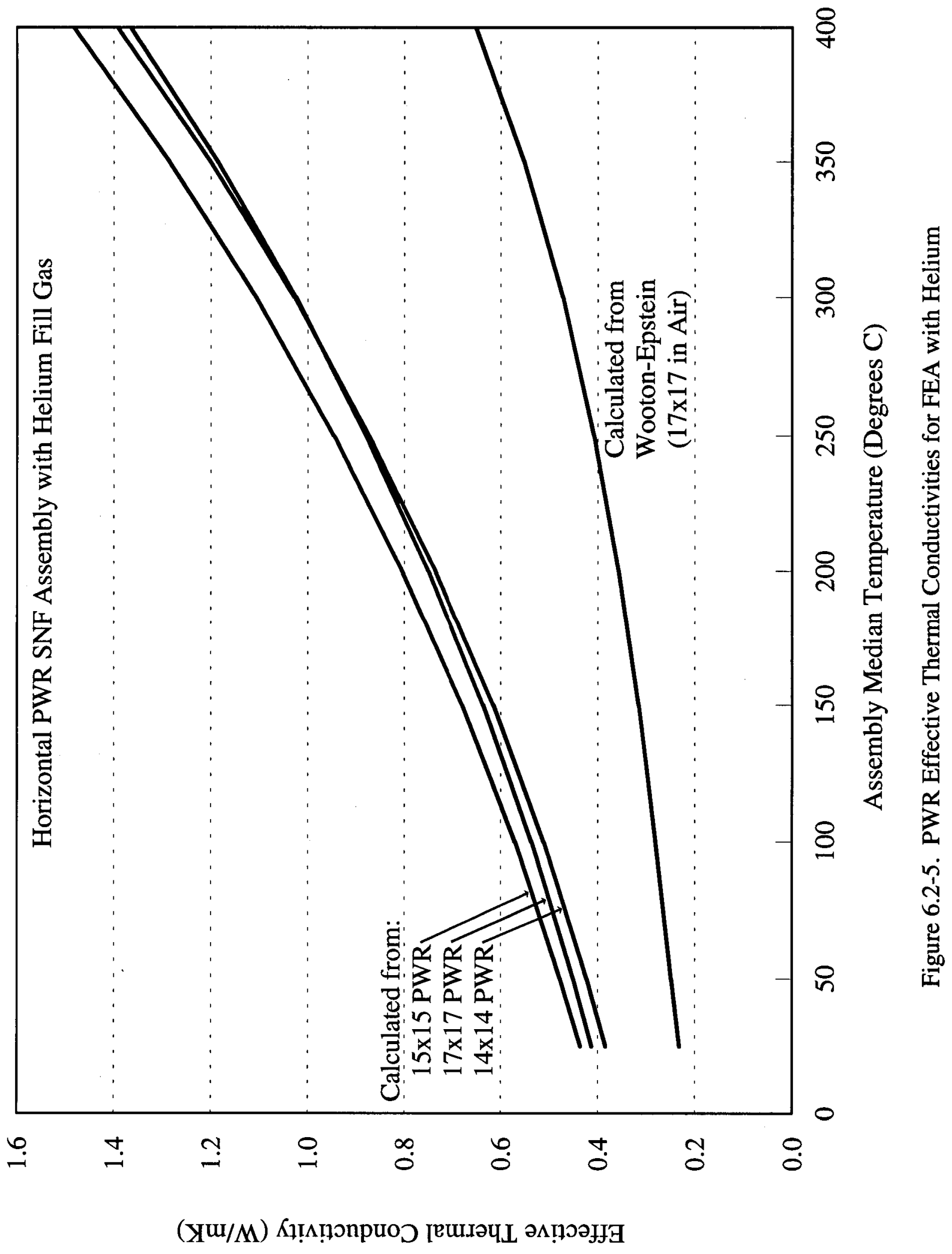




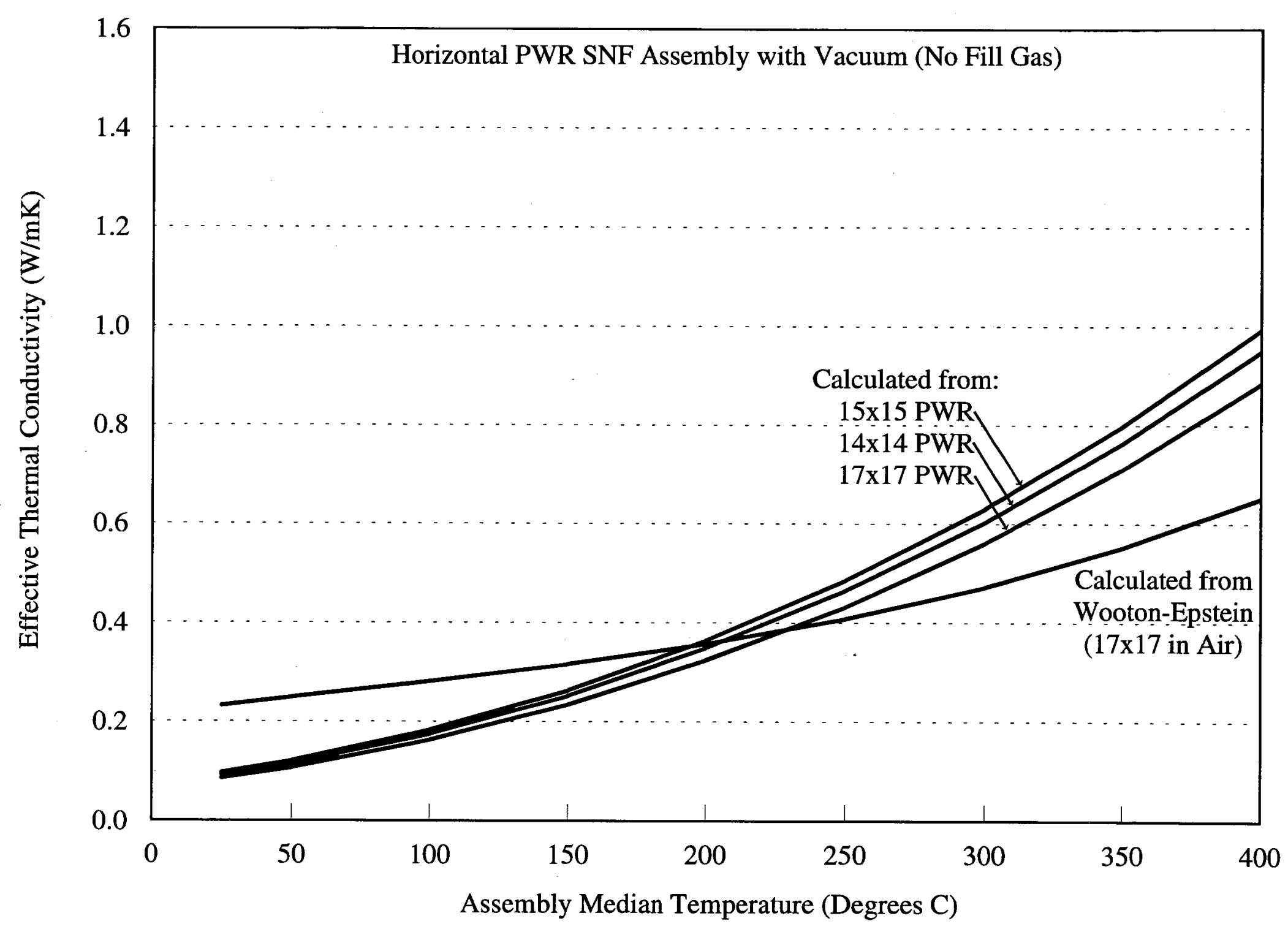

Figure 6.2-6. PWR Effective Thermal Conductivities for FEA with Vacuum 


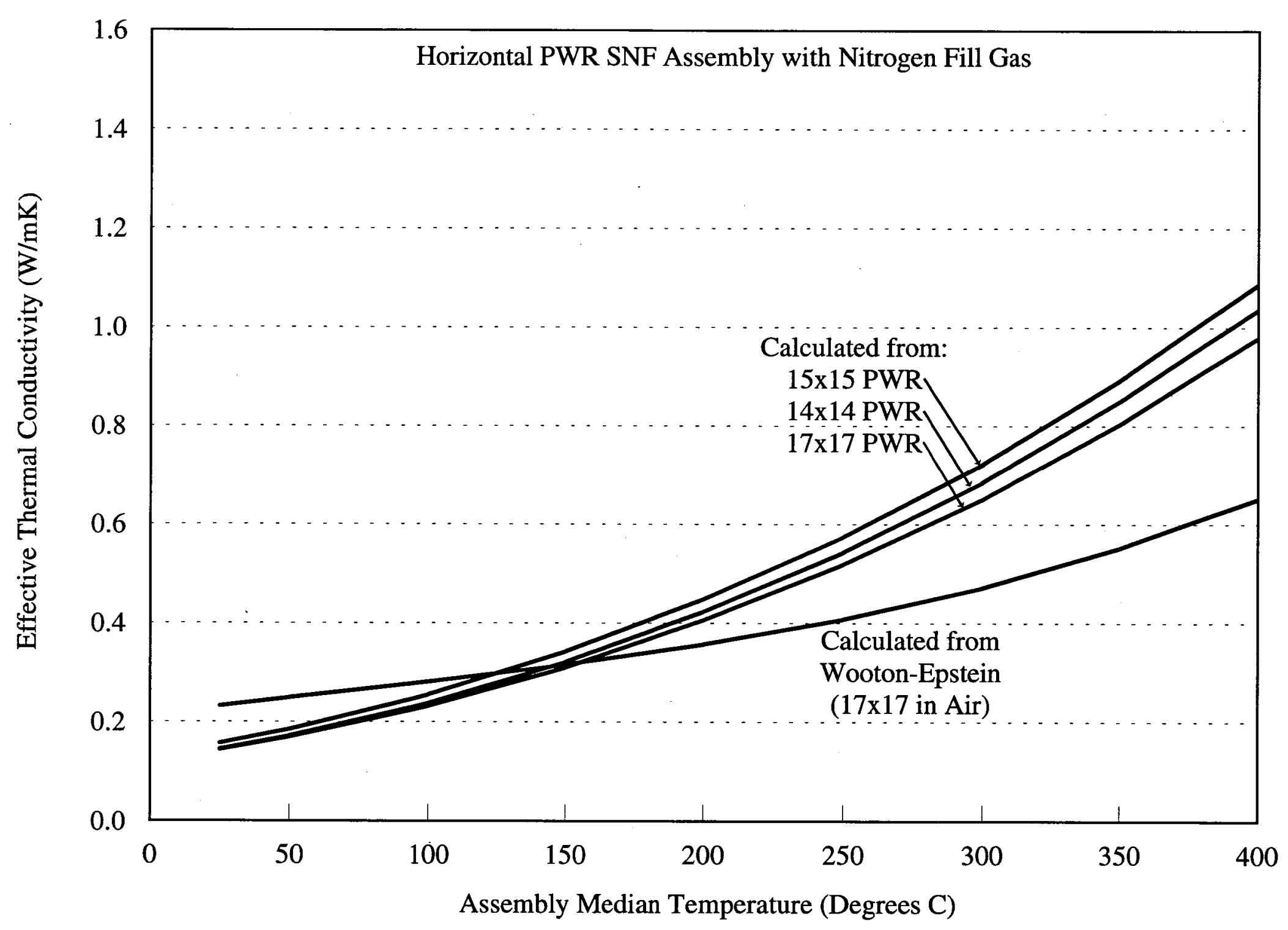

Figure 6.2-7. PWR Effective Thermal Conductivities for FEA with Nitrogen 


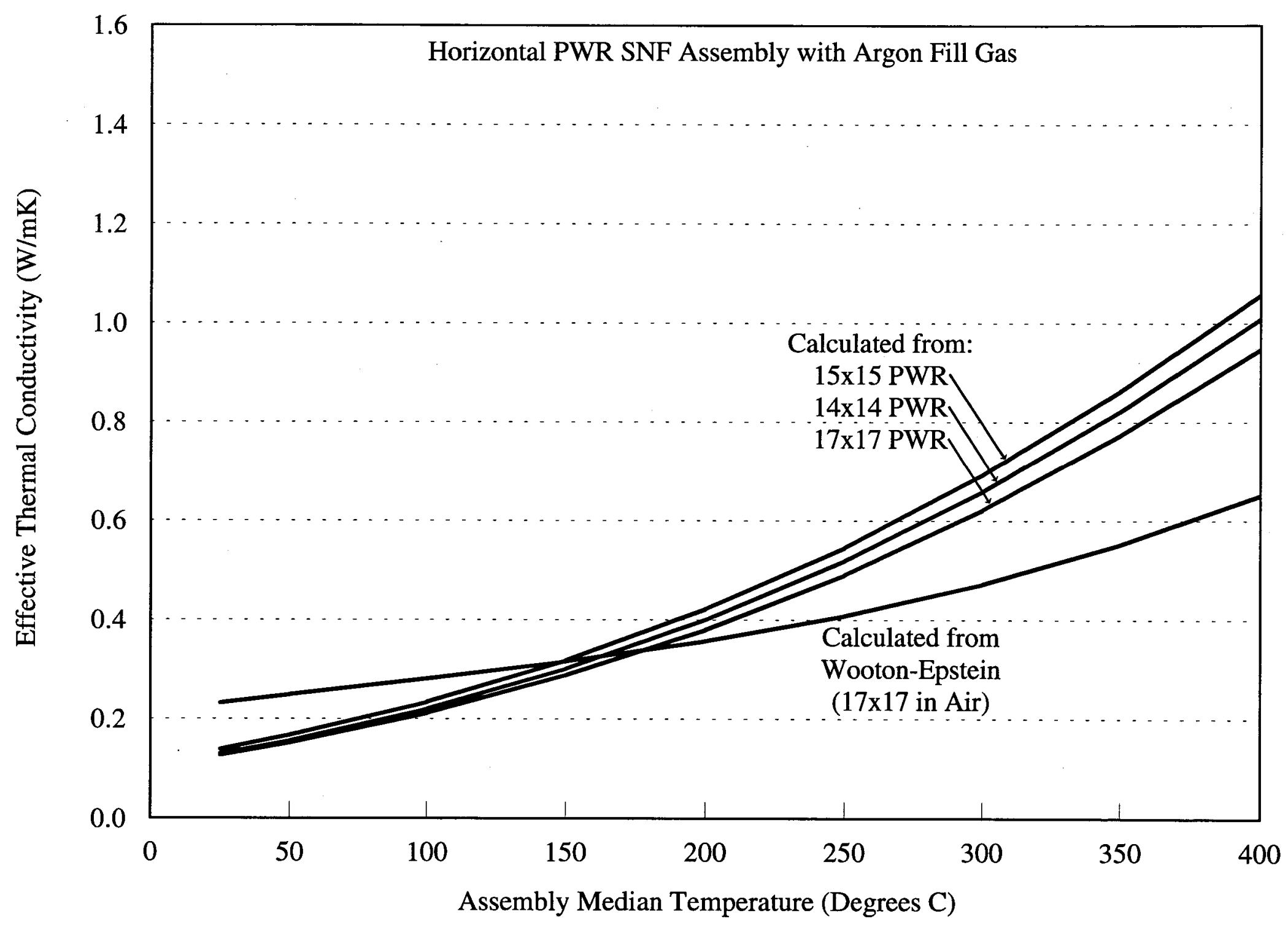

Figure 6.2-8. PWR Effective Thermal Conductivities for FEA with Argon 
Table 6.2-2 summarizes the bounding results (based on assembly median temperature) for PWR assemblies. To develop the values in Table 6.2-2, a third-order polynomial curve fit was performed (see Equations 6.2-1 through 6.2-4 below) to the calculated effective thermal conductivities as a function of assembly median temperature. The resulting equations were then evaluated at the temperatures listed in Table 6.2-2. As discussed above, the $14 \times 14$ array was bounding for helium fill gas and the $17 \times 17$ array is bounding for vacuum, nitrogen, and argon. While the different PWR assembly designs resulted in very small differences (and can be bounded by one assembly array for each fill gas), results for different fill environments were significant. Therefore, the appropriate effective thermal conductivity should be chosen for use based on the expected fill gas for thermal evaluations of SNF containers. Comparisons between the fill environments are provided in Section 6.4.1.

Table 6.2-2. Effective Conductivities for PWR SNF (for FEA)

\begin{tabular}{||c||c|c|c|c||}
\hline $\begin{array}{c}\text { Assembly } \\
\text { Median } \\
\text { Temperature }\end{array}$ & $\begin{array}{c}\mathrm{k}_{\mathrm{e}} \text { for FEA } \\
(\mathrm{W} / \mathrm{m} \cdot \mathrm{K}) \\
14 \times 14 \text { Array } \\
\text { in Helium }\end{array}$ & $\begin{array}{c}\mathrm{K}_{\mathrm{e}} \text { for FEA } \\
(\mathrm{W} / \mathrm{m} \cdot \mathrm{K}) \\
17 \times 17 \text { Array } \\
\text { in Vacuum }\end{array}$ & $\begin{array}{c}\mathrm{K}_{\mathrm{e}} \text { for FEA } \\
(\mathrm{W} / \mathrm{m} \cdot \mathrm{K}) \\
17 \times 17 \text { Array } \\
\text { in Nitrogen }\end{array}$ & $\begin{array}{c}\mathrm{K}_{\mathrm{e}} \text { for FEA } \\
(\mathrm{W} / \mathrm{m} \cdot \mathrm{K}) \\
17 \times 17 \text { Array } \\
\text { in Argon }\end{array}$ \\
\hline \hline $25^{\circ} \mathrm{C}$ & 0.384 & 0.086 & 0.144 & 0.127 \\
\hline $50^{\circ} \mathrm{C}$ & 0.423 & 0.107 & 0.170 & 0.152 \\
\hline $100^{\circ} \mathrm{C}$ & 0.512 & 0.163 & 0.232 & 0.212 \\
\hline $150^{\circ} \mathrm{C}$ & 0.616 & 0.234 & 0.310 & 0.288 \\
\hline $200^{\circ} \mathrm{C}$ & 0.736 & 0.324 & 0.406 & 0.380 \\
\hline $250^{\circ} \mathrm{C}$ & 0.874 & 0.432 & 0.519 & 0.491 \\
\hline $300^{\circ} \mathrm{C}$ & 1.028 & 0.561 & 0.651 & 0.622 \\
\hline $350^{\circ} \mathrm{C}$ & 1.201 & 0.711 & 0.804 & 0.774 \\
\hline $400^{\circ} \mathrm{C}$ & 1.392 & 0.884 & 0.978 & 0.948 \\
\hline
\end{tabular}

For finite element codes which allow the input of an equation rather than tabular data for material properties, a polynomial curve fit has been performed for each of the bounding cases described above (Equations 6.2-1 through 6.2-4). The third-order fit ${ }^{[46]}$ correlated effective thermal conductivity $\left(\mathrm{k}_{\mathrm{e}}\right)$ as a function of assembly median temperature $\left(\mathrm{T}_{\mathrm{m}}=\left[\mathrm{T}_{\text {basket }}+\mathrm{T}_{\text {peak }}\right] / 2\right)$. Also, one of these equations can be substituted into Equation 6.1-5 which then provides an equation for peak cladding temperatures as a function of the median temperature, thus eliminating the table lookup to determine a value for $\mathrm{k}_{\mathrm{e}}$. 
14x14 PWR SNF with helium backfill gas:

$$
k_{e}=0.3490+1.334 \times 10^{-3} T_{m}+2.849 \times 10^{-6} T_{m}^{2}+8.359 \times 10^{-10} T_{m}^{3}
$$

(Equation 6.2-1)

17x17 PWR SNF with vacuum (no backfill gas):

$$
k_{e}=0.0678+6.483 \times 10^{-4} T_{m}+2.825 \times 10^{-6} T_{m}^{2}+1.644 \times 10^{-9} T_{m}^{3}
$$

(Equation 6.2-2)

17x17 PWR SNF with nitrogen backfill gas:

$$
k_{e}=0.1219+8.182 \times 10^{-4} T_{m}+2.698 \times 10^{-6} T_{m}^{2}+1.514 \times 10^{-9} T_{m}^{3}
$$

(Equation 6.2-3)

17x17 PWR SNF with argon backfill gas:

$$
k_{e}=0.1055+7.953 \times 10^{-4} T_{m}+2.513 \times 10^{-6} T_{m}^{2}+1.916 \times 10^{-9} T_{m}^{3}
$$

(Equation 6.2-4)

The following recommendations should be followed when using the effective thermal conductivity data with finite element codes. It should be noted that only even mesh grids (i.e., 10x10, 14x 14, etc.) should be used when using the effective thermal conductivity data and finite element codes. This mesh spacing places a local node at the center of the SNF assembly and will calculate a temperature at this location directly. If an odd spacing is used, the mesh will interpolate this point consistent with the finite element method. The accuracy of different mesh densities in a homogeneous SNF assembly is discussed in Section 7.1. When calculating the heat load to apply to the SNF region, use the cross sectional area or volume of the modeled region, not the area or volume of the SNF assembly. Using the SNF assembly area or volume will result in a larger heat load per volume for the modeled region and the calculation will over-predict the peak SNF cladding temperatures. The PWR basket cell width assumed for these analyses was 0.2235 meters ( 8.8 inches). However, the size of the basket opening should not affect the calculation or invalidate the effective thermal conductivity. The derivation of the effective thermal conductivity does not depend on the basket width; it is only an average thermal conductivity for the region being modeled. Also, increasing the gap between the SNF assembly and the basket wall should have a minimal effect since the heat transfer is predominately by radiation; however, this can be affected by fill gas conductivity. Generally, for reasonable basket designs, the gap size will not have a significant impact on the use of the effective thermal conductivity. 


\subsection{BWR Assembly Geometries}

The determination of effective thermal conductivities for the BWR assemblies follows the same pattern as for the PWR assemblies. Effective thermal conductivities are defined as a function of both SNF basket wall temperature and assembly median temperature (for use in FEA analyses).

\subsubsection{Effective Conductivity for Known Basket Wall Temperatures}

Equation 6.1-5 was used to predict an effective thermal conductivity for each BWR assembly configuration for each temperature and heat load evaluated. Using the assembly analysis results from Section 4, the calculation was performed for the 9x9, 8x8, and 7x7 BWR arrays with and without an 80 mil channel in each fill environment (helium, vacuum, nitrogen, and argon) and for the Wooton-Epstein results for the 9x9 PWR assembly (bounding the results for the $8 \times 8$ and $7 \times 7$ arrays). Details of the results are provided in the supporting BWR design analyses ${ }^{[49,50,51]}$ and summary results are provided here.

As expected, the effective thermal conductivity results are highly temperature-dependent for each assembly and fill environment; however, for the discrete SNF model results, there was little dependence on the assembly heat load (calculated values varied only slightly with heat load for the same basket temperature). This is contrasted to the Wooton-Epstein results where there was some dependence on heat load observed, though less evident than the temperature dependence.

As discussed in the PWR Section 6.2.1, some thermal analysis codes are capable of solving with temperature-dependent material properties; however, very few can handle more than one dimension of nonlinearity in the properties. If the heat load dependence for the effective thermal conductivity can be shown to be small, then a more useful conductivity can be defined that is a function of temperature only. The results strongly suggest that the effective thermal conductivity is either weakly dependent upon heat load or is not dependent upon heat load at all. Thus, a temperaturedependent effective thermal conductivity can be determined for each SNF basket wall temperature by averaging the values over the heat loads for each basket temperature. This temperature-dependent conductivity could then be used to predict peak cladding temperatures given the basket wall temperature, the assembly heat load, and Equation 6.1-5.

Figures 6.3-1, 6.3-2, 6.3-3, and 6.3-4 provide graphical comparisons of the average (over the six heat loads) effective thermal conductivity for the $9 \times 9$ and $7 \times 7$ BWR assembly configurations (with channel and without) in fill environments of helium, vacuum, nitrogen, and argon, respectively. As seen in Section 4, the results for the 8x8 array were just slightly cooler than those for the 9x9 array and therefore will predict nearly the same effective thermal conductivity. For the vacuum cases (Figure 6.3-2), thermal radiation is the only heat transfer mechanism between the SNF rods and the basket wall. Therefore, the 9x9 PWR assembly (which has more layers of rods to confound thermal radiation) results in the most conservative effective thermal conductivity. Similarly for fill gases of nitrogen and argon (Figures 6.3-3 and 6.3-4), where radiation heat transfer dominates gaseous conduction, the $9 \times 9$ array is the most conservative. However, unlike the PWR results, the $9 \times 9$ was also the most conservative for the helium fill gas (Figure 6.3-1). In all cases, BWR assemblies with the channel were more conservative (lower $\mathrm{k}_{\mathrm{e}}$ ) than assemblies without a channel. 


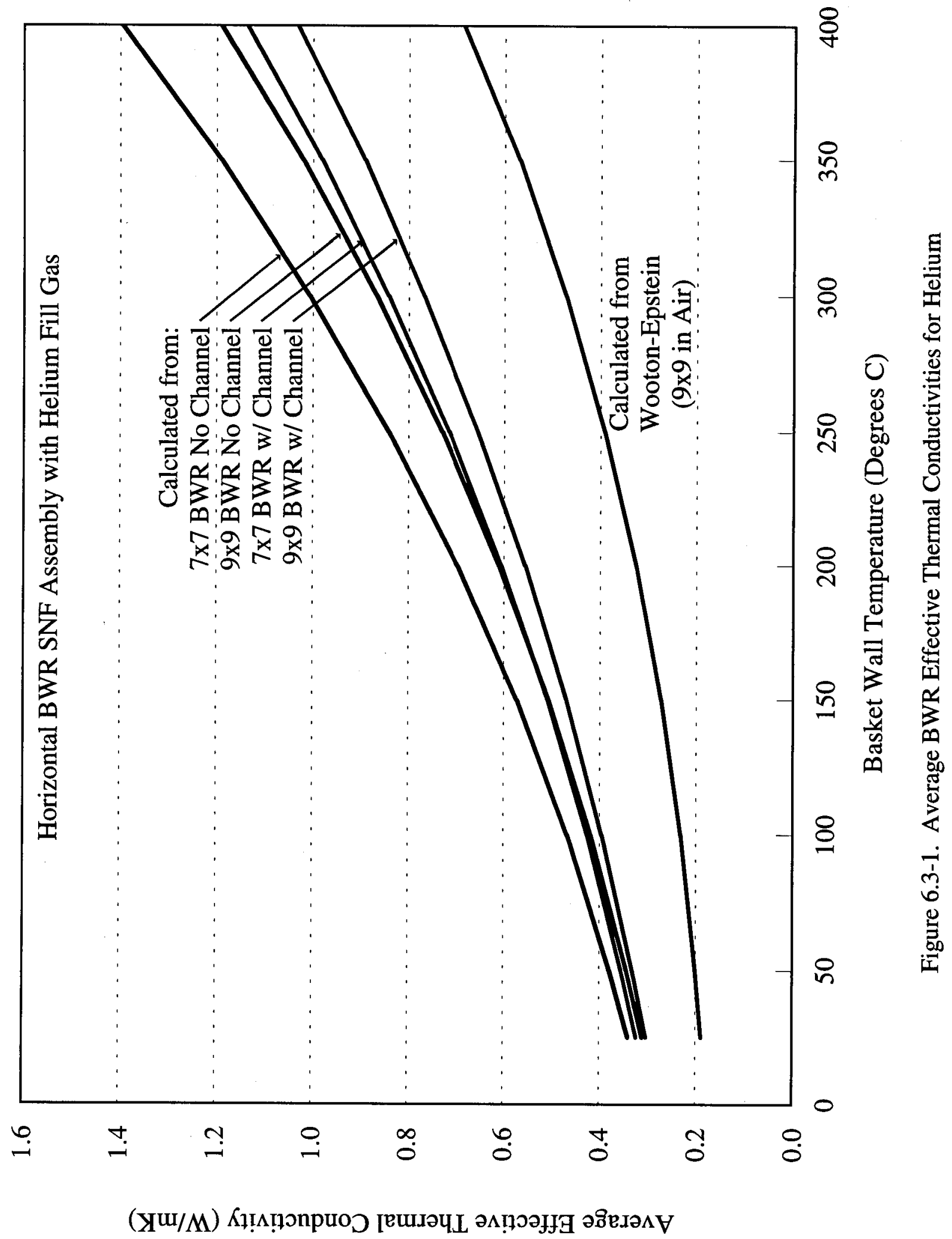




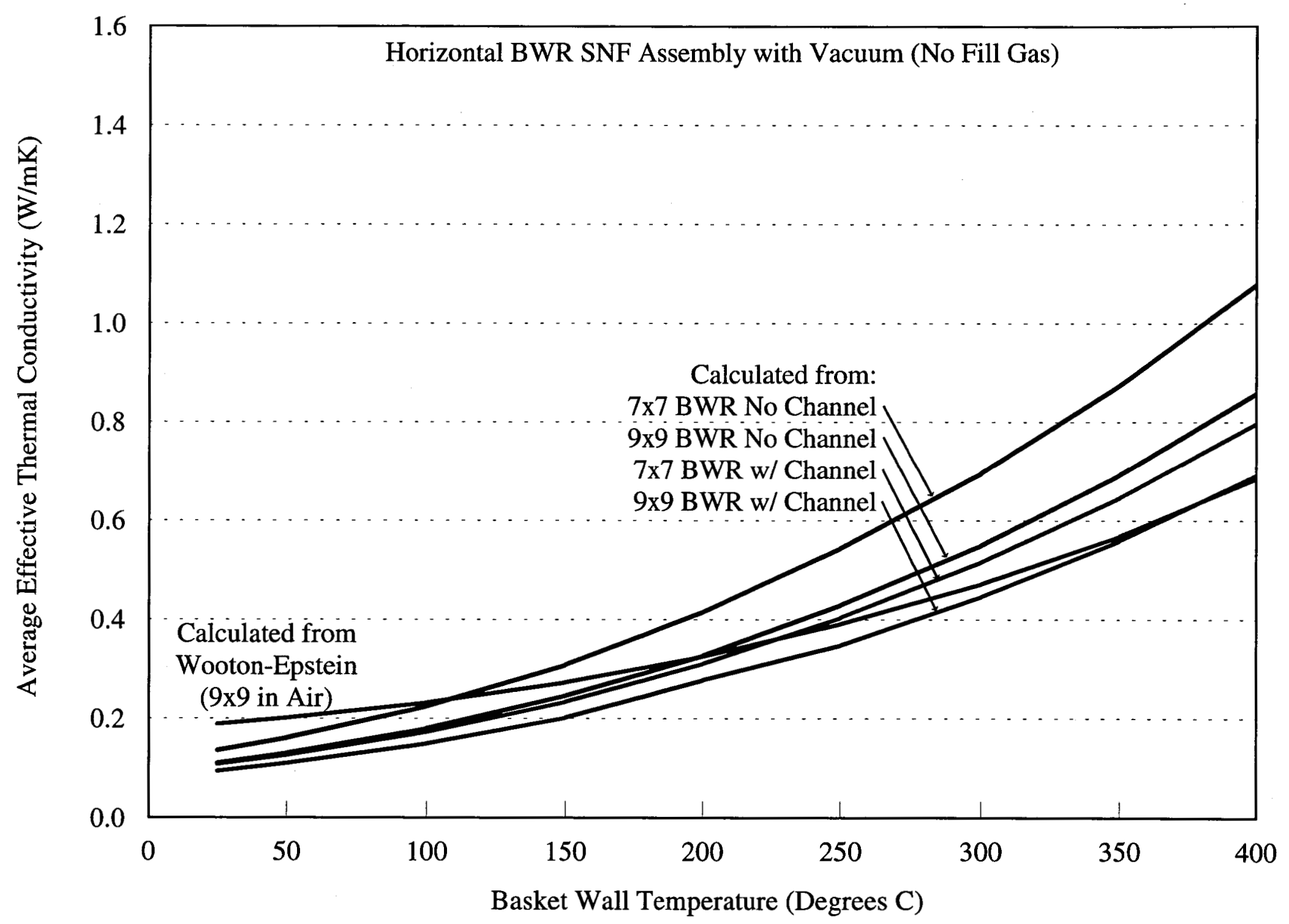

Figure 6.3-2. Average BWR Effective Thermal Conductivities for Vacuum 


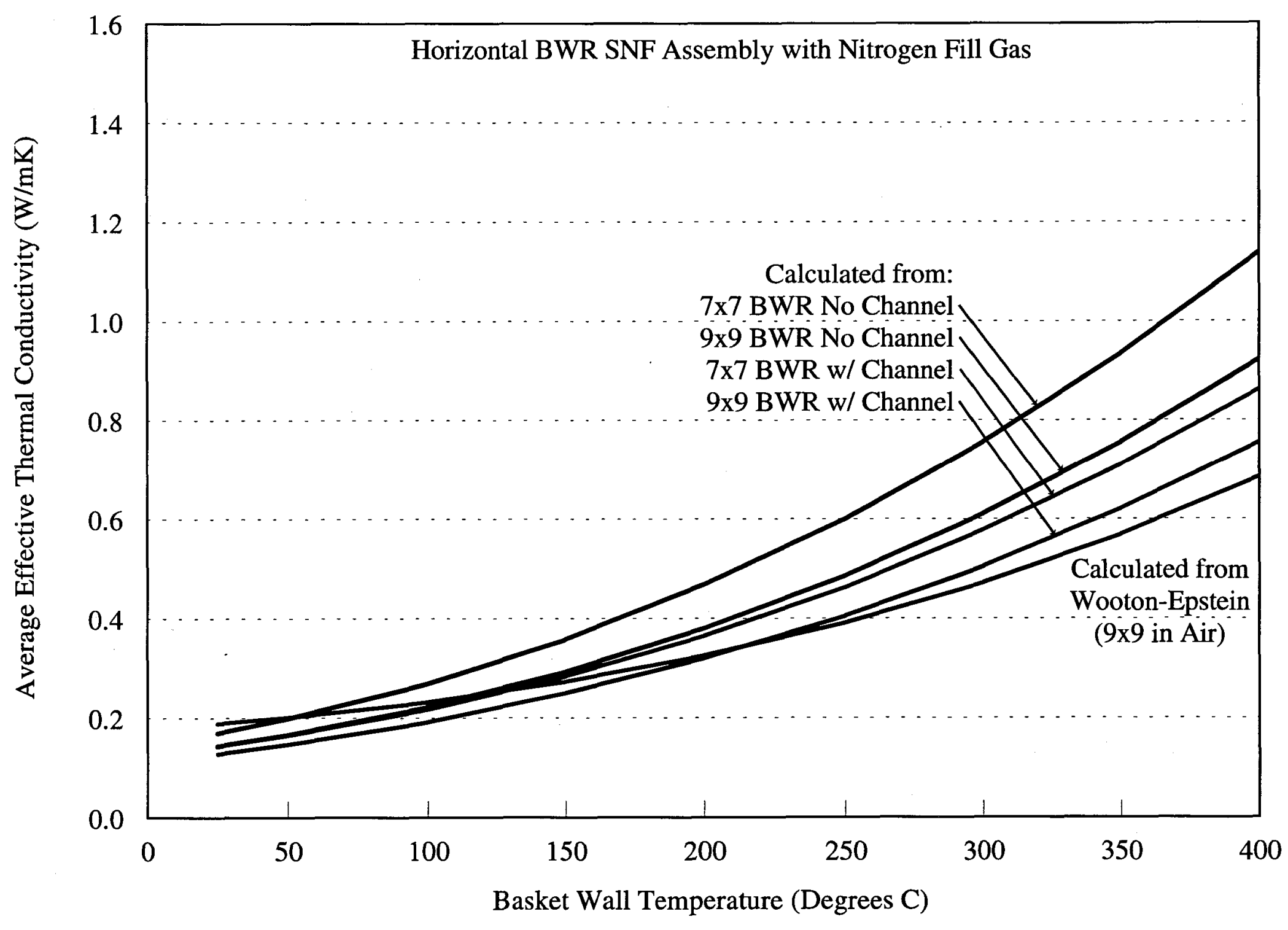

Figure 6.3-3. Average BWR Effective Thermal Conductivities for Nitrogen 


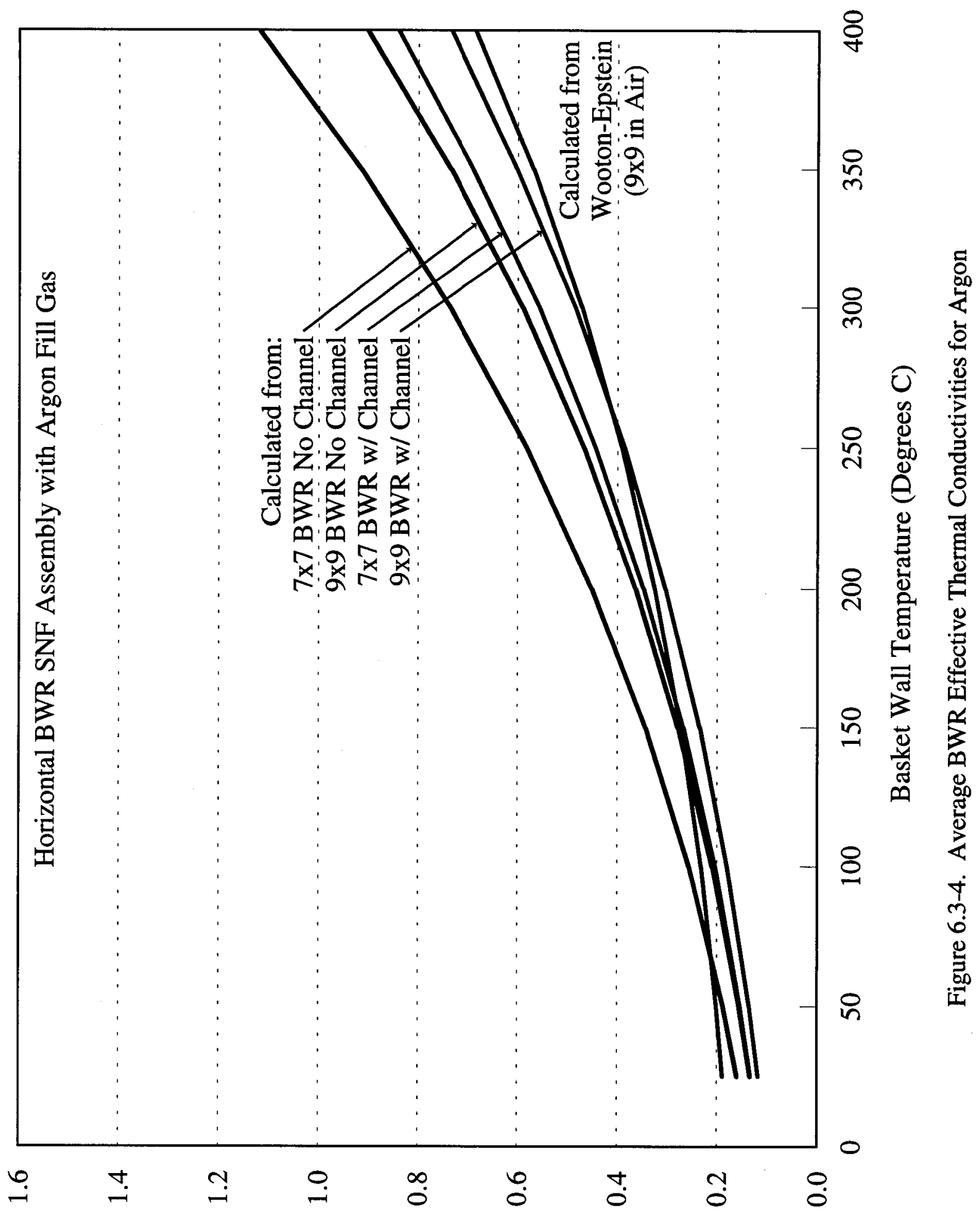

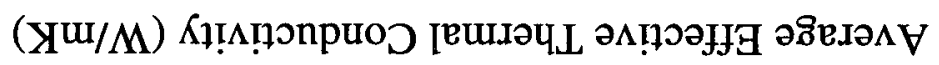


Average effective thermal conductivities calculated from the Wooton-Epstein results of Section 5 are also plotted for comparison in Figures 6.3-1, 6.3-2, 6.3-3, and 6.3-4. The most conservative results (those for the $9 \mathrm{x} 9 \mathrm{BWR}$ array) were chosen for comparison. For assemblies with helium fill gas, the Wooton-Epstein correlation would result in significantly over-predicted peak cladding temperatures compared to using the effective thermal conductivity method. For nitrogen and argon, however, Wooton-Epstein is seen to be nonconservative at basket temperatures less than $100^{\circ} \mathrm{C}$ and a close match (or slightly conservative) for higher temperatures. Wooton-Epstein is seen to be nonconservative for all temperatures for BWR assemblies in a vacuum. Note that the WootonEpstein correlation was developed only for PWR-sized arrays with a fill gas of air (which is closest here to the nitrogen fill gas).

Tables 6.3-1 and 6.3-2 summarizes the bounding results (based on basket wall temperature) for BWR assemblies with and without channels, respectively. As discussed above, the 9x9 array was bounding for all of the fill environments. BWR assemblies without channels can be evaluated using the effective thermal conductivities for assemblies with channels, however, this approach may be overly conservative for some evaluations. Therefore, the conductivities for BWR assemblies both with and without channels are reported here. However, if a "generic" BWR assembly is the target of a thermal evaluation, it is recommended that the effective thermal conductivities for channeled BWR assemblies be used to be conservative.

While the different BWR assembly designs resulted in minor differences (and can be bounded by one assembly array), results for different fill environments were significant. Therefore, the appropriate effective thermal conductivity should be chosen for use based on the expected fill environment for thermal evaluations of SNF containers. Comparisons between the fill environments are provided in Section 6.4.1.

Table 6.3-1. Average Effective Conductivities for BWR SNF, with Channel

\begin{tabular}{||c||c|c|c|c||}
\hline $\begin{array}{c}\text { Basket Wall } \\
\text { Temperature }\end{array}$ & $\begin{array}{c}\text { Average } \mathrm{k}_{\mathrm{e}} \\
(\mathrm{W} / \mathrm{m} \cdot \mathrm{K}) \\
9 \times 9 \mathrm{Array} \\
\text { in Helium }\end{array}$ & $\begin{array}{c}\text { Average } \mathrm{k}_{\mathrm{e}} \\
(\mathrm{W} / \mathrm{m} \cdot \mathrm{K}) \\
9 \times 9 \text { Array } \\
\text { in Vacuum }\end{array}$ & $\begin{array}{c}\text { Average } \mathrm{k}_{\mathrm{e}} \\
(\mathrm{W} / \mathrm{m} \cdot \mathrm{K}) \\
9 \times 9 \text { Array } \\
\text { in Nitrogen }\end{array}$ & $\begin{array}{c}\text { Average } \mathrm{k}_{\mathrm{e}} \\
(\mathrm{W} / \mathrm{m} \cdot \mathrm{K}) \\
9 \times 9 \text { Array } \\
\text { in Argon }\end{array}$ \\
\hline \hline $25^{\circ} \mathrm{C}$ & 0.303 & 0.094 & 0.128 & 0.118 \\
\hline $50^{\circ} \mathrm{C}$ & 0.332 & 0.110 & 0.147 & 0.136 \\
\hline $100^{\circ} \mathrm{C}$ & 0.396 & 0.150 & 0.192 & 0.180 \\
\hline $150^{\circ} \mathrm{C}$ & 0.470 & 0.202 & 0.250 & 0.235 \\
\hline $200^{\circ} \mathrm{C}$ & 0.556 & 0.278 & 0.320 & 0.304 \\
\hline $250^{\circ} \mathrm{C}$ & 0.655 & 0.348 & 0.405 & 0.386 \\
\hline $300^{\circ} \mathrm{C}$ & 0.768 & 0.446 & 0.505 & 0.485 \\
\hline $350^{\circ} \mathrm{C}$ & 0.892 & 0.560 & 0.621 & 0.602 \\
\hline $400^{\circ} \mathrm{C}$ & 1.032 & 0.692 & 0.755 & 0.735 \\
\hline
\end{tabular}


Table 6.3-2. Average Effective Conductivities for BWR SNF, No Channel

\begin{tabular}{|c||c|c|c|c||}
\hline $\begin{array}{c}\text { Basket Wall } \\
\text { Temperature }\end{array}$ & $\begin{array}{c}\text { Average } \mathrm{k}_{e} \\
(\mathrm{~W} / \mathrm{m} \cdot \mathrm{K}) \\
9 \times 9 \text { Array } \\
\text { in Helium }\end{array}$ & $\begin{array}{c}\text { Average } \mathrm{k}_{\mathrm{e}} \\
(\mathrm{W} / \mathrm{m} \cdot \mathrm{K}) \\
9 \times 9 \text { Array } \\
\text { in Vacuum }\end{array}$ & $\begin{array}{c}\text { Average } \mathrm{k}_{\mathrm{e}} \\
(\mathrm{W} / \mathrm{m} \cdot \mathrm{K}) \\
9 \times 9 \text { Array } \\
\text { in Nitrogen }\end{array}$ & $\begin{array}{c}\text { Average } \mathrm{k}_{\mathrm{e}} \\
(\mathrm{W} / \mathrm{m} \cdot \mathrm{K}) \\
9 \times 9 \text { Array } \\
\text { in Argon }\end{array}$ \\
\hline \hline $25^{\circ} \mathrm{C}$ & 0.311 & 0.110 & 0.144 & 0.134 \\
\hline $50^{\circ} \mathrm{C}$ & 0.344 & 0.130 & 0.166 & 0.156 \\
\hline $100^{\circ} \mathrm{C}$ & 0.419 & 0.180 & 0.223 & 0.210 \\
\hline $150^{\circ} \mathrm{C}$ & 0.507 & 0.246 & 0.293 & 0.279 \\
\hline $200^{\circ} \mathrm{C}$ & 0.611 & 0.327 & 0.380 & 0.364 \\
\hline $250^{\circ} \mathrm{C}$ & 0.730 & 0.429 & 0.486 & 0.467 \\
\hline $300^{\circ} \mathrm{C}$ & 0.867 & 0.550 & 0.611 & 0.591 \\
\hline $350^{\circ} \mathrm{C}$ & 1.021 & 0.693 & 0.756 & 0.736 \\
\hline $400^{\circ} \mathrm{C}$ & 1.192 & 0.858 & 0.922 & 0.902 \\
\hline
\end{tabular}

\subsubsection{Effective Conductivity for Finite Element Analysis}

The BWR SNF effective thermal conductivity presented in Section 6.3.1 is an average thermal conductivity for determining peak cladding temperature given the basket wall temperature. However, as discussed for PWRs in Section 6.2.2, finite element codes determine the material property values used for a node location based upon the node temperature, not an external temperature like a basket wall temperature.

Since finite element codes, such as ANSYS, are useful engineering design tools, it is very desirable to determine effective thermal conductivity which can be used accurately with finite element codes. The simplest method is to re-scale the data presented in Section 6.3.1 from a basket wall temperature basis to a temperature scale based on the assembly median temperature. The median temperature is defined here as the temperature halfway between the basket temperature and the calculated peak temperature for each data solution case.

The use of an effective thermal conductivity determined with Equation 6.1-5 based on median temperature will allow a finite element code to over-predict the effective thermal conductivity on roughly half of the local nodes and under-predict the effective thermal conductivity on the remaining half of the local nodes. In this manner, the average SNF thermal conductivity for the global SNF assembly will be the same as the average effective thermal conductivity determined with the basket wall temperature and the Section 6.3.1 results. A second benefit to defining the conductivity as a function of median temperature is to eliminate the slight dependence on assembly heat load observed with the values based on basket wall temperature. In this case, the portions of the assembly 
experiencing higher than median temperatures (and the effects due to radiation heat transfer) are balanced by the portions of the assembly experiencing lower than median temperatures. This method based on median temperature was back checked as documented in Section 7.1 and benchmarked as documented in Sections 7.2 and 7.3.

Figures 6.3-5, 6.3-6, 6.3-7, and 6.3-8 provide graphical comparisons of the effective thermal conductivity (defined as a function of median temperature) for the $9 \times 9$ and $7 \times 7$ BWR assembly configurations (with an 80 mil channel and without) in fill environments of helium, vacuum, nitrogen, and argon, respectively. Results for the $8 \times 8$ BWR assembly have been omitted because they are just slightly nonconservative compared to the results for the $9 \times 9$ array. Again, for the vacuum cases (Figure 6.3-6), thermal radiation is the only heat transfer mechanism between the SNF rods and the basket wall. Therefore, the $9 \times 9$ BWR assembly (which has more layers of rods to confound thermal radiation) results in the most conservative effective thermal conductivity. Similarly for fill gases of nitrogen and argon (Figures 6.3-7 and 6.3-8), where radiation heat transfer dominates gaseous conduction, the $9 \times 9$ array is the most conservative. In a fill gas of helium (Figure 6.3-5), the $9 \times 9$ array was again the most conservative. As in the previous section, BWR assemblies with the channel were substantially more conservative than assemblies with the channel removed for all of the fill environments.

Effective thermal conductivities calculated from the Wooton-Epstein results of Section 5 are also plotted (as a function of median temperature) for comparison in Figures 6.3-5, 6.3-6, 6.3-7, and 6.38. Again, for assemblies with helium fill gas, the Wooton-Epstein correlation would result in significantly over-predicted peak cladding temperatures compared to using the effective thermal conductivity method. For nitrogen and argon, however, Wooton-Epstein is seen to be nonconservative at low basket temperatures and just slightly conservative at high basket temperatures. Wooton-Epstein is seen to be nonconservative for all temperatures for BWR assemblies in a vacuum. Note that the Wooton-Epstein correlation was developed only for PWRsized arrays with a fill gas of air (which is closest here to the nitrogen fill gas).

Tables 6.3-3 and 6.3-4 summarizes the bounding results (based on assembly median temperature) for BWR assemblies with and without channels, respectively. To develop the values in Table 6.3-3 and 6.3-4, a polynomial curve fit was performed (see Equations 6.3-1 through 6.3-8 below) to the calculated effective thermal conductivities as a function of assembly median temperature. The resulting equations were then evaluated at the temperatures listed in Table 6.3-3. As discussed above, the 9x9 array was bounding for all of the fill environments. BWR assemblies without channels can be evaluated using the effective thermal conductivities for assemblies with channels, however, this approach may be overly conservative for some evaluations. Therefore, the conductivities for BWR assemblies both with and without channels are reported here. However, if a "generic" BWR assembly is the target of a thermal evaluation, it is recommended that the effective thermal conductivities for channeled BWR assemblies be used to be conservative. 


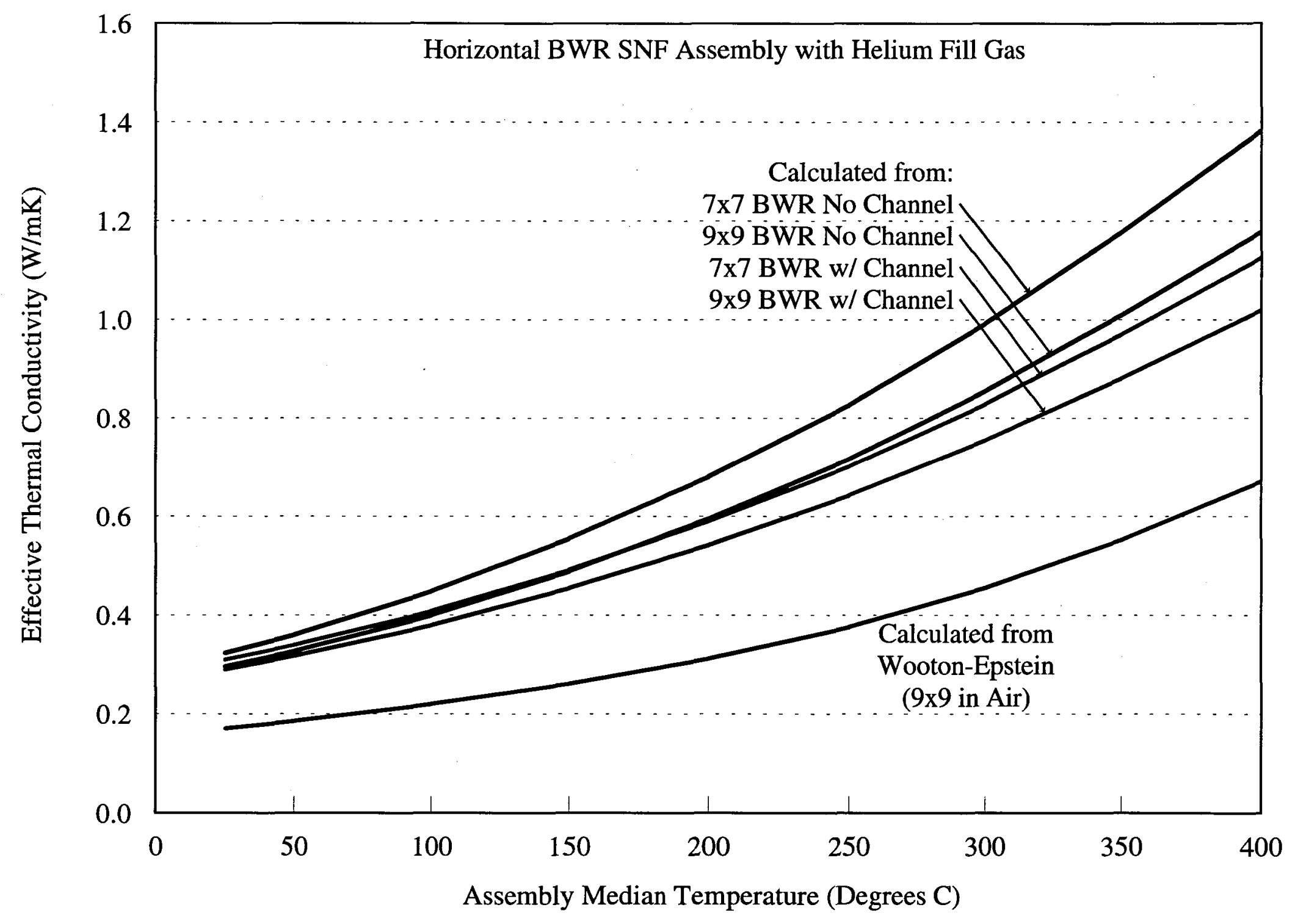

Figure 6.3-5. BWR Effective Thermal Conductivities for FEA with Helium 


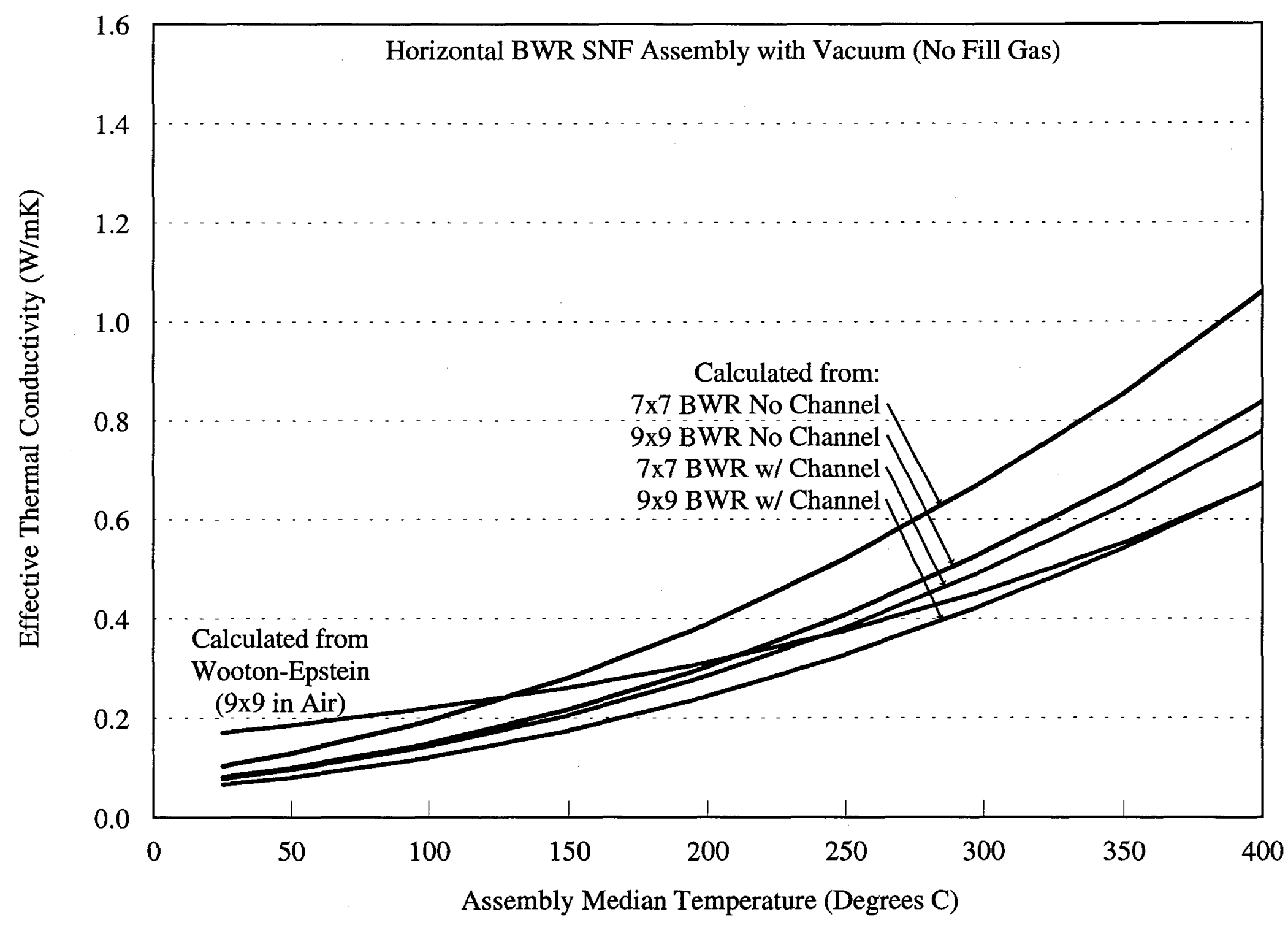

Figure 6.3-6. BWR Effective Thermal Conductivities for FEA with Vacuum 


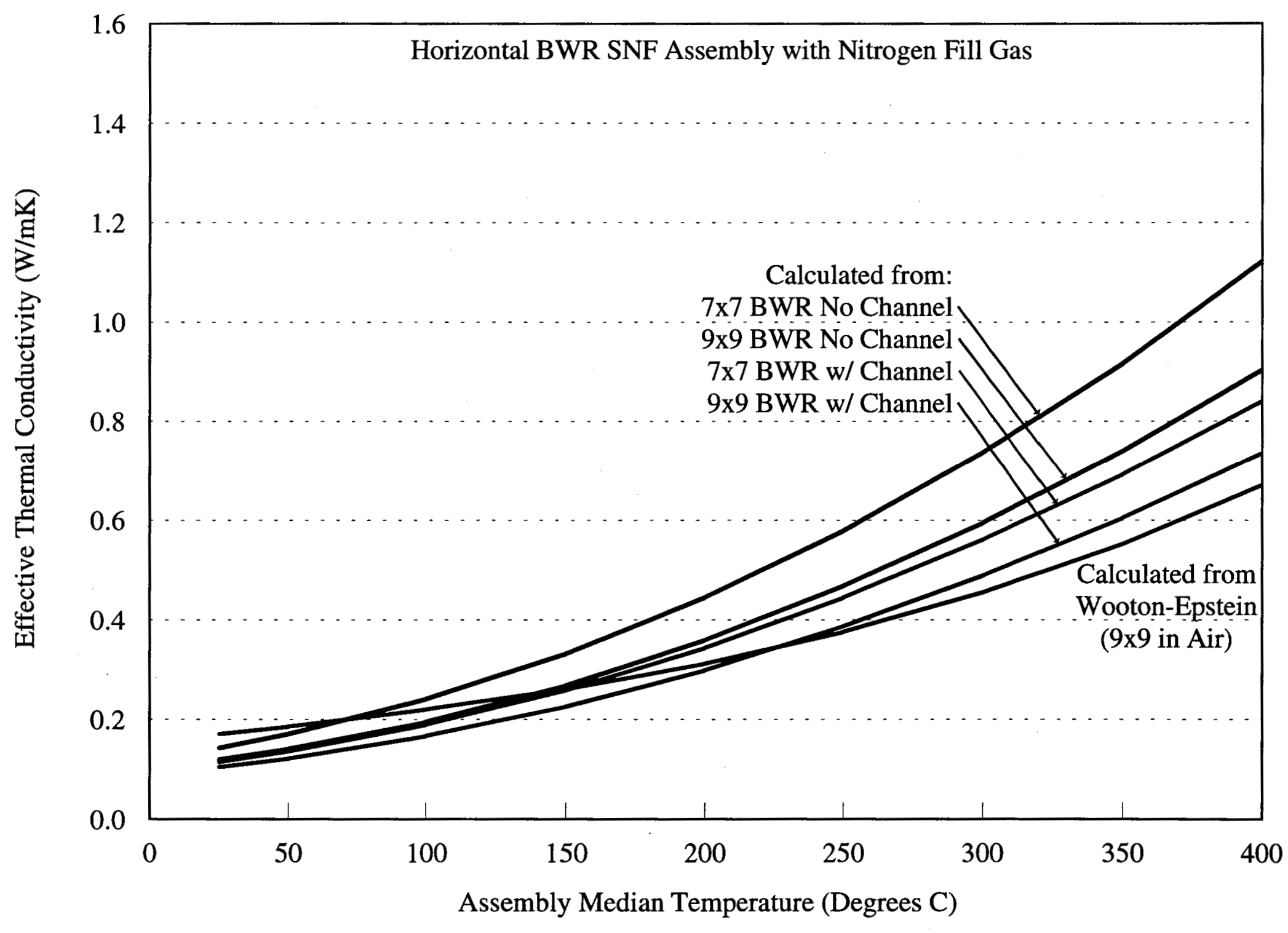

Figure 6.3-7. BWR Effective Thermal Conductivities for FEA with Nitrogen 


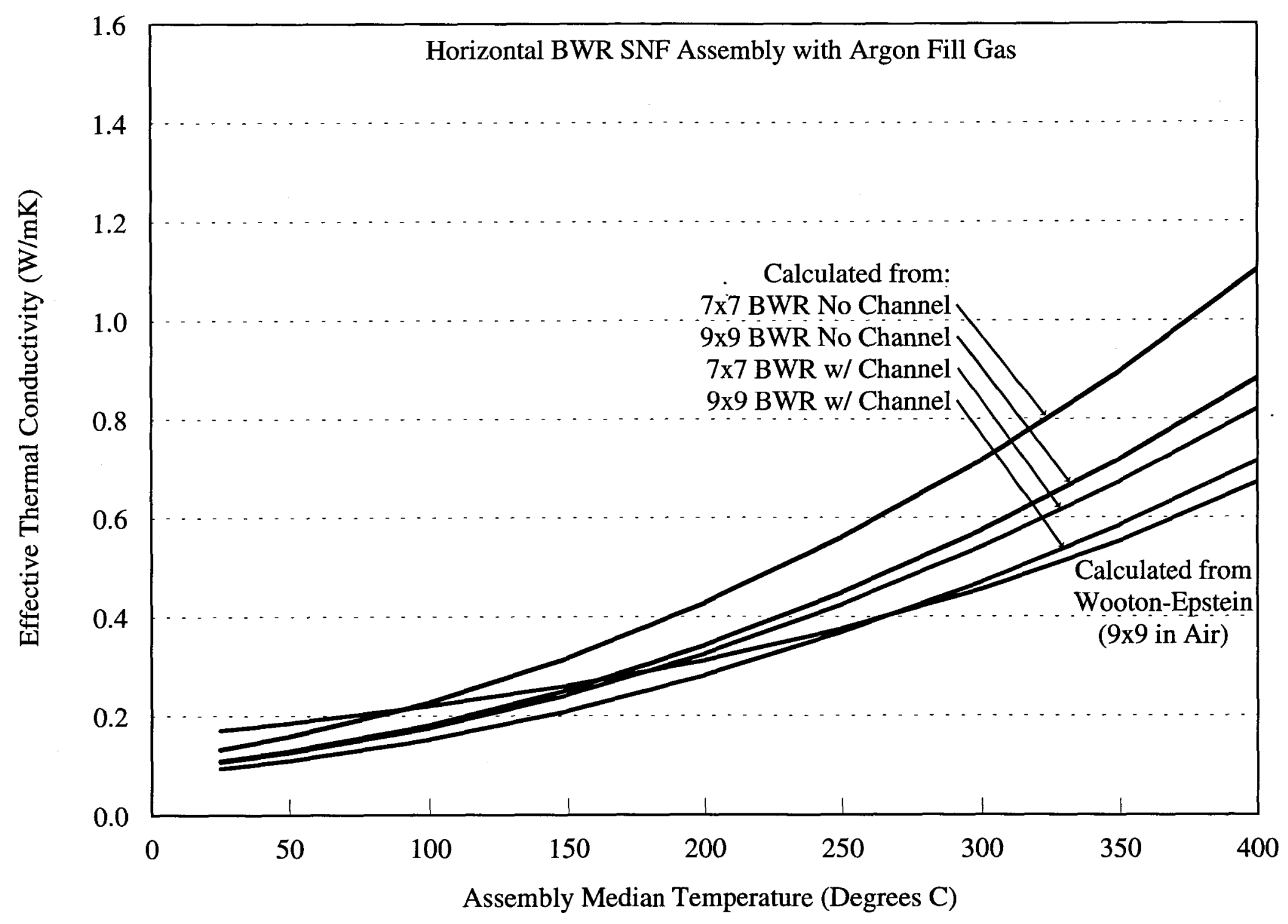

Figure 6.3-8. BWR Effective Thermal Conductivities for FEA with Argon 
While the different BWR assembly designs resulted in minor differences (and can be bounded by one assembly array), results for different fill environments were significant. Therefore, the appropriate effective thermal conductivity should be chosen for use based on the expected fill environment for thermal evaluations of SNF containers. Comparisons between the fill environments are provided in Section 6.4.1.

Table 6.3-3. Effective Conductivities for BWR SNF (for FEA), with Channel

\begin{tabular}{|c||c|c|c|c||}
\hline $\begin{array}{c}\text { Assembly } \\
\text { Median } \\
\text { Temperature }\end{array}$ & $\begin{array}{c}\mathrm{K}_{\mathrm{e}} \text { for FEA } \\
\text { (W/m } \cdot \mathrm{K}) \\
9 \times 9 \text { Array } \\
\text { in Helium }\end{array}$ & $\begin{array}{c}\mathrm{K}_{\mathrm{e}} \text { for FEA } \\
\text { (W/m } \cdot \mathrm{K}) \\
9 \times 9 \text { Array } \\
\text { in Vacuum }\end{array}$ & $\begin{array}{c}\mathrm{K}_{\mathrm{e}} \text { for FEA } \\
\text { (W/m/K) } \\
9 \times 9 \text { Array } \\
\text { in Nitrogen }\end{array}$ & $\begin{array}{c}\mathrm{K}_{\mathrm{e}} \text { for FEA } \\
(\mathrm{W} / \mathrm{m} \cdot \mathrm{K}) \\
9 \times 9 \text { Array } \\
\text { in Argon }\end{array}$ \\
\hline \hline $25^{\circ} \mathrm{C}$ & 0.290 & 0.067 & 0.105 & 0.094 \\
\hline $50^{\circ} \mathrm{C}$ & 0.317 & 0.081 & 0.122 & 0.110 \\
\hline $100^{\circ} \mathrm{C}$ & 0.379 & 0.121 & 0.167 & 0.153 \\
\hline $150^{\circ} \mathrm{C}$ & 0.455 & 0.175 & 0.226 & 0.210 \\
\hline $200^{\circ} \mathrm{C}$ & 0.542 & 0.244 & 0.299 & 0.282 \\
\hline $250^{\circ} \mathrm{C}$ & 0.643 & 0.328 & 0.387 & 0.369 \\
\hline $300^{\circ} \mathrm{C}$ & 0.755 & 0.427 & 0.489 & 0.470 \\
\hline $350^{\circ} \mathrm{C}$ & 0.881 & 0.542 & 0.605 & 0.585 \\
\hline $400^{\circ} \mathrm{C}$ & 1.019 & 0.673 & 0.736 & 0.715 \\
\hline
\end{tabular}

For finite element codes which allow the input of an equation rather than tabular data for material properties, a third-order polynomial curve fit has been performed for each of the bounding cases described above (Equations 6.3-1 through 6.3-8). The third-order fit ${ }^{[46]}$ correlated effective thermal conductivity $\left(k_{e}\right)$ as a function of assembly median temperature $\left(T_{m}=\left[T_{\text {basket }}+T_{\text {peak }}\right] / 2\right)$. Also, one of these equations can be substituted into Equation 6.1-5 which then provides an equation for peak cladding temperatures as a function of the median temperature, thus eliminating the table lookup to determine a value for $\mathrm{k}_{\mathrm{e}}$. 
Table 6.3-4. Effective Conductivities for BWR SNF (for FEA), No Channel

\begin{tabular}{||c||c|c|c|c||}
\hline $\begin{array}{c}\text { Assembly } \\
\text { Median } \\
\text { Temperature }\end{array}$ & $\begin{array}{c}\mathrm{K}_{e} \text { for FEA } \\
(\mathrm{W} / \mathrm{m} \cdot \mathrm{K}) \\
9 \times 9 \text { Array } \\
\text { in Helium }\end{array}$ & $\begin{array}{c}\mathrm{K}_{e} \text { for FEA } \\
(\mathrm{W} / \mathrm{m} \cdot \mathrm{K}) \\
9 \times 9 \text { Array } \\
\text { in Vacuum }\end{array}$ & $\begin{array}{c}\mathrm{K}_{e} \text { for FEA } \\
(\mathrm{W} / \mathrm{m} \cdot \mathrm{K}) \\
9 \times 9 \text { Array } \\
\text { in Nitrogen }\end{array}$ & $\begin{array}{c}\mathrm{K}_{\mathrm{e}} \text { for FEA } \\
\text { (W/m· } \mathrm{K}) \\
9 \times 9 \text { Array } \\
\text { in Argon }\end{array}$ \\
\hline \hline $25^{\circ} \mathrm{C}$ & 0.296 & 0.082 & 0.120 & 0.109 \\
\hline $50^{\circ} \mathrm{C}$ & 0.327 & 0.100 & 0.141 & 0.129 \\
\hline $100^{\circ} \mathrm{C}$ & 0.400 & 0.149 & 0.195 & 0.181 \\
\hline $150^{\circ} \mathrm{C}$ & 0.489 & 0.217 & 0.268 & 0.252 \\
\hline $200^{\circ} \mathrm{C}$ & 0.595 & 0.303 & 0.359 & 0.342 \\
\hline $250^{\circ} \mathrm{C}$ & 0.717 & 0.408 & 0.468 & 0.449 \\
\hline $300^{\circ} \mathrm{C}$ & 0.855 & 0.533 & 0.595 & 0.575 \\
\hline $350^{\circ} \mathrm{C}$ & 1.009 & 0.676 & 0.740 & 0.719 \\
\hline $400^{\circ} \mathrm{C}$ & 1.178 & 0.838 & 0.903 & 0.882 \\
\hline
\end{tabular}

9x9 BWR SNF with channel in helium backfill gas:

$$
k_{e}=0.2668+8.750 \times 10^{-4} T_{m}+2.513 \times 10^{-6} T_{m}^{2}
$$

(Equation 6.3-1)

9x9 BWR SNF with channel in vacuum (no backfill gas):

$$
k_{e}=0.0562+3.630 \times 10^{-4} T_{m}+2.801 \times 10^{-6} T_{m}^{2}+3.640 \times 10^{-10} T_{m}^{3}
$$

(Equation 6.3-2)

9x9 BWR SNF with channel in nitrogen backfill gas:

$$
k_{e}=0.0913+4.680 \times 10^{-4} T_{m}+2.861 \times 10^{-6} T_{m}^{2}
$$

(Equation 6.3-3)

9x9 BWR SNF with channel in argon backfill gas:

$$
k_{e}=0.0820+4.090 \times 10^{-4} T_{m}+2.997 \times 10^{-6} T_{m}^{2}-1.627 \times 10^{-10} T_{m}^{3}
$$

(Equation 6.3-4) 
9x9 BWR SNF, no channel in helium backfill gas:

$$
k_{e}=0.2705+9.550 \times 10^{-4} T_{m}+3.391 \times 10^{-6} T_{m}^{2}-2.700 \times 10^{-10} T_{m}^{3}
$$

(Equation 6.3-5)

9x9 BWR SNF, no channel in vacuum (no backfill gas):

$$
k_{e}=0.0690+4.340 \times 10^{-4} T_{m}+3.652 \times 10^{-6} T_{m}^{2}+1.786 \times 10^{-10} T_{m}^{3}
$$

(Equation 6.3-6)

9x9 BWR SNF, no channel in nitrogen backfill gas:

$$
k_{e}=0.1044+5.380 \times 10^{-4} T_{m}+3.676 \times 10^{-6} T_{m}^{2}-7.725 \times 10^{-11} T_{m}^{3}
$$

(Equation 6.3-7)

9x9 BWR SNF, no channel in argon backfill gas:

$$
k_{e}=0.0946+5.040 \times 10^{-4} T_{m}+3.644 \times 10^{-6} T_{m}^{2}+4.459 \times 10^{-11} T_{m}^{3}
$$

(Equation 6.3-8)

The following recommendations should be followed when using the effective thermal conductivity data with finite element codes. It should be noted that only even mesh grids (i.e., 10x10, 14x14, etc.) should be used when using the effective thermal conductivity data and finite element codes. This mesh spacing places a local node at the center of the SNF assembly and will calculate a temperature at this location directly. If an odd spacing is used, the mesh will interpolate this point consistent with the finite element method. The accuracy of different mesh densities in a homogeneous SNF assembly is discussed in Section 7.1. When calculating the heat load to apply to the SNF region, use the cross sectional area or volume of the modeled region, not the area or volume of the SNF assembly. Using the SNF assembly area or volume will result in a larger heat load per volume for the modeled region and the calculation will over-predict the peak SNF cladding temperatures. The BWR basket cell width assumed for these analyses was 0.1524 meters ( 6.0 inches). However, the size of the basket opening should not affect the calculation or invalidate the effective thermal conductivity. The derivation of the effective thermal conductivity does not depend on the basket width; it is only an average thermal conductivity for the region being modeled. Also, increasing the gap between the SNF assembly and the basket wall should have a minimal effect since the heat transfer is predominately by radiation; however, this can be affected by fill environment conductivity. Generally, for reasonable basket designs, the gap size will not have a significant impact on the use of the effective thermal conductivity. 


\subsection{Effective Thermal Conductivity Comparisons}

\subsubsection{Fill Environment Effects}

Figure 6.4-1 provides a comparison of the recommended PWR effective thermal conductivities for each fill environment option. While the curves for vacuum, nitrogen, and argon are closely spaced, it is obvious that the use of helium as an SNF container fill gas can significantly reduce peak cladding temperatures. Further, the use of a correlation (such as Wooton-Epstein) developed for assemblies in air could limit the design of SNF containers by over-predicting SNF cladding temperatures. This impact could, for example, be the difference between designing a 21 PWR capacity WP versus a 12 PWR capacity WP as a maximum allowable capacity, for designs limited by peak cladding temperature requirements (the WP cost difference can be large). Again, for fill environments of vacuum, nitrogen, and argon, the Wooton-Epstein correlation is seen to be conservative for higher temperatures and somewhat nonconservative for lower temperatures.

Figures 6.4-2 and 6.4-3 provide comparisons of the recommended BWR effective thermal conductivities for each fill environment option with and without an 80 mil channel, respectively. Similar trending to the PWR SNF is observed for both the channel and no channel cases. For both with and without a channel for the BWR assembly, the fill environments of vacuum, nitrogen, and argon are closely grouped with the results of Wooton-Epstein correlation. Helium, however, provides a much higher effective thermal conductivity, and therefore would provide significantly lower temperatures in SNF containers that are filled with helium.

\subsubsection{Assembly Designs}

Finally, comparisons between PWR and BWR effective thermal conductivities are presented for fill gases of helium and nitrogen in Figures 6.4-4 and 6.4-5, respectively. Figure 6.4-4 also compares the effective thermal conductivities derived from the discrete SNF models with effective thermal conductivities developed by General Atomics for the GA-4 $4^{[33]}$ and GA- $9^{[34]}$ casks. For PWR assemblies, the GA-4 values are found to be just slightly more conservative (mostly at higher temperatures). BWR effective thermal conductivities reported for the GA-9 cask, however, were found to be significantly nonconservative compared to the SNF model results and the WootonEpstein correlation. Also, a single value (at $315^{\circ} \mathrm{C}$ ) for PWR assemblies in helium is reported in the safety analysis for the NAC Storable Transport Cask, ${ }^{[37]}$ and it is seen to agree closely with effective thermal conductivity for the $14 \times 14$ array at the same temperature.

Note that in the comparisons between different assembly geometries, each assembly design ( $17 \times 17$, $15 \times 15$, etc.) will have a different active fuel length, and therefore a different linear heat production (watts/meter length) for each given heat load. This accounts for some of the small differences between cases; for example, the $14 \times 14$ array, with an active length of $3472.2 \mathrm{~mm}$ (136.7 inches), resulted in higher temperatures than the $17 \times 17$ array, with an active length of $3657.6 \mathrm{~mm}$ (144.0 inches), for the same heat load. The BWR assembly lengths ranged from $3657.6 \mathrm{~mm}$ (144 inches) to $3810.0 \mathrm{~mm}$ (150 inches). 


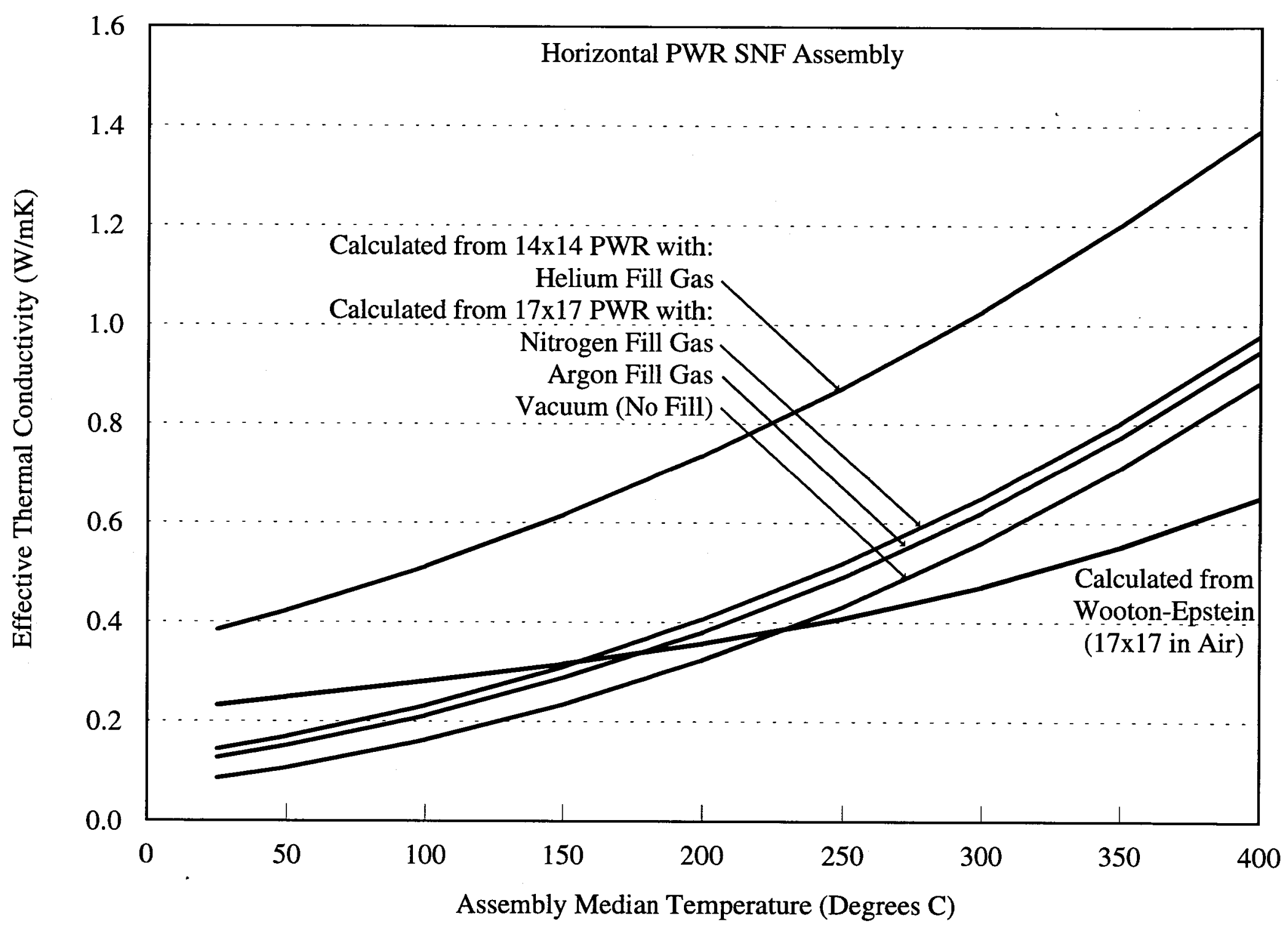

Figure 6.4-1. Fill Gas Comparison for PWR Effective Thermal Conductivities

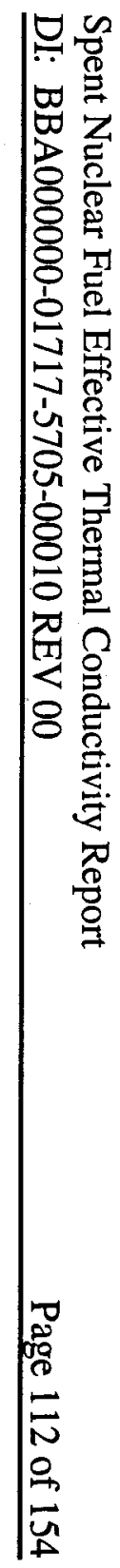




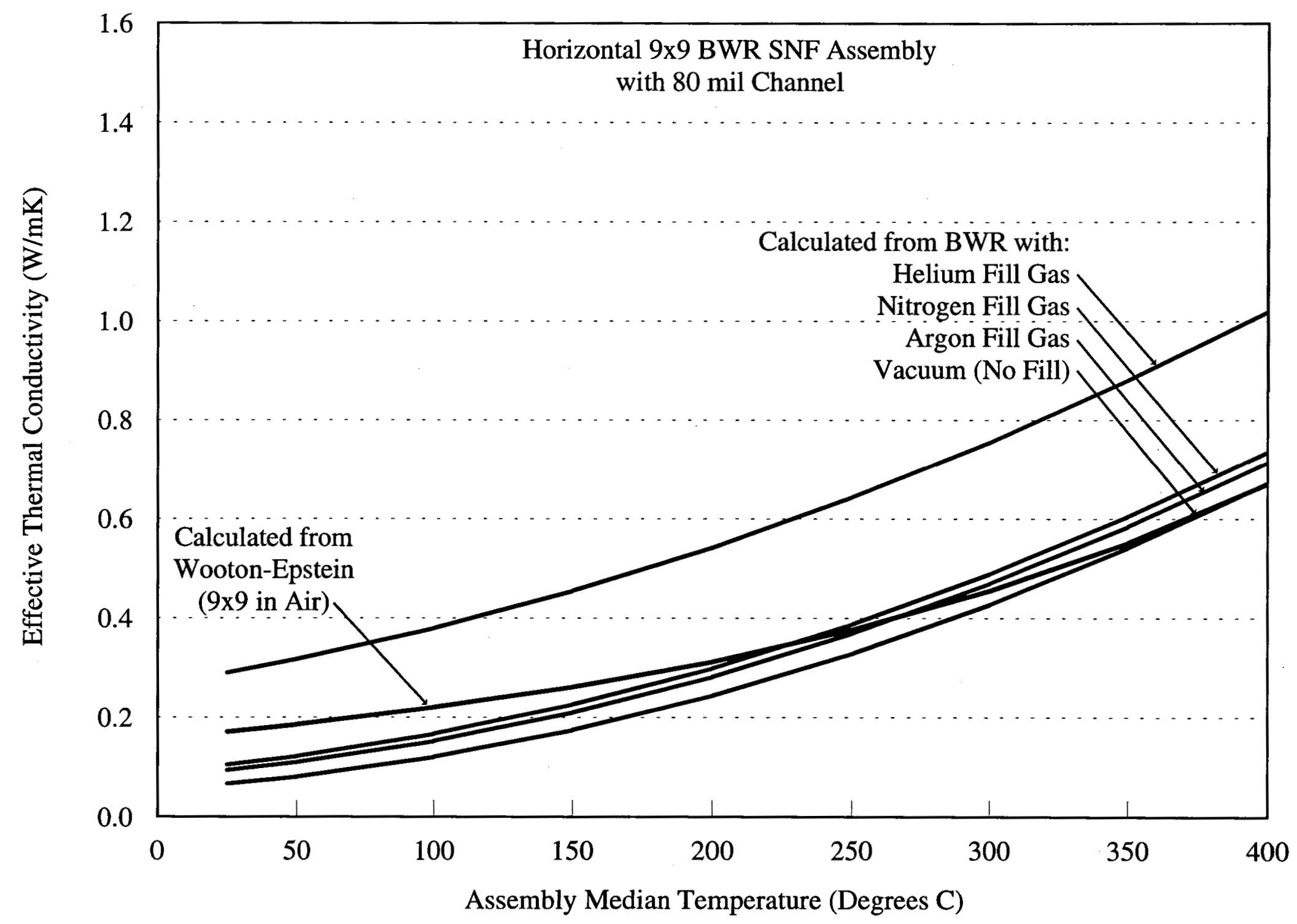

Figure 6.4-2. Fill Gas Comparison for BWR (w/ Channel) Effective Conductivities 


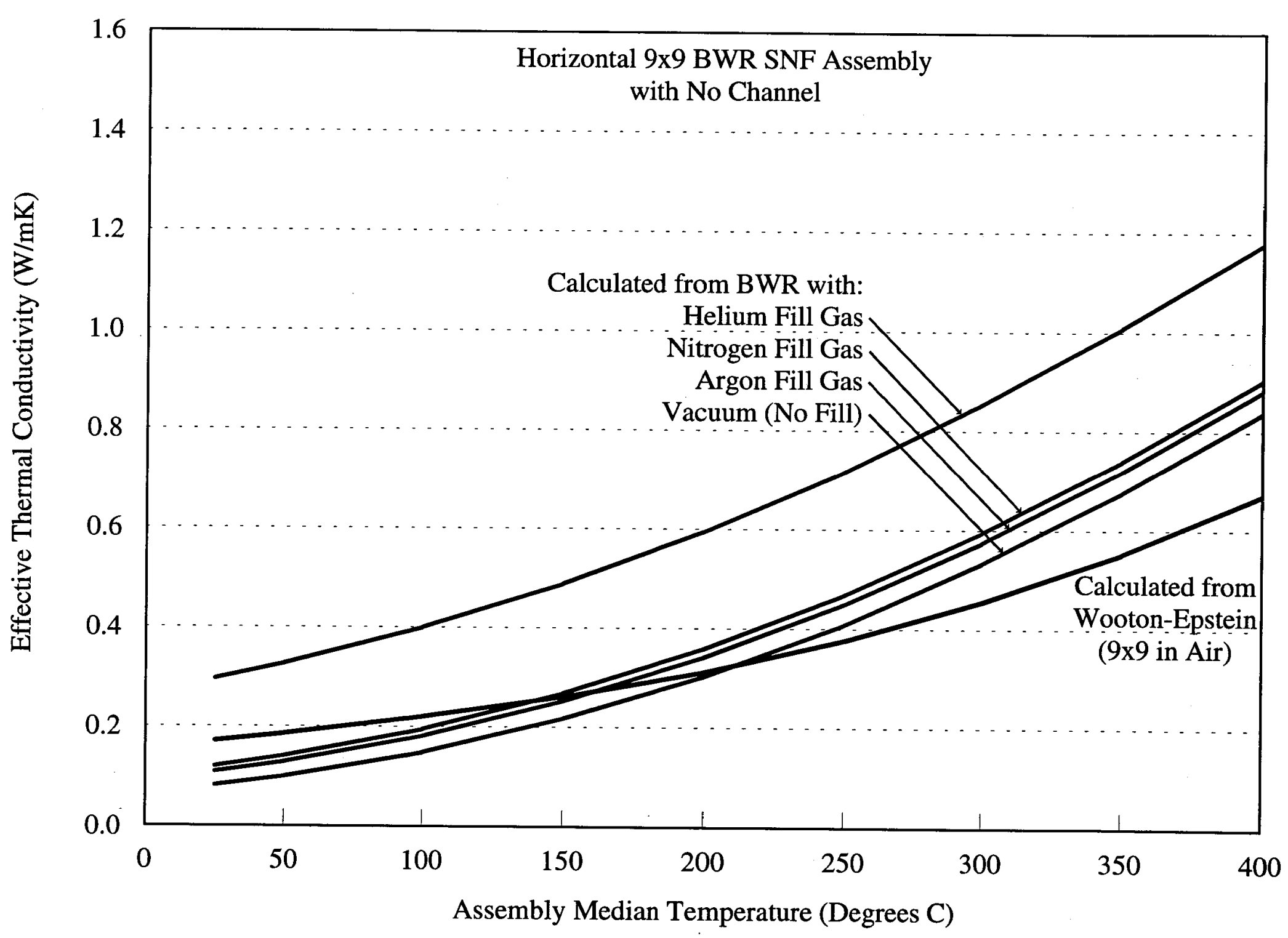

Figure 6.4-3. Fill Gas Comparison for BWR (No Channel) Effective Conductivities 


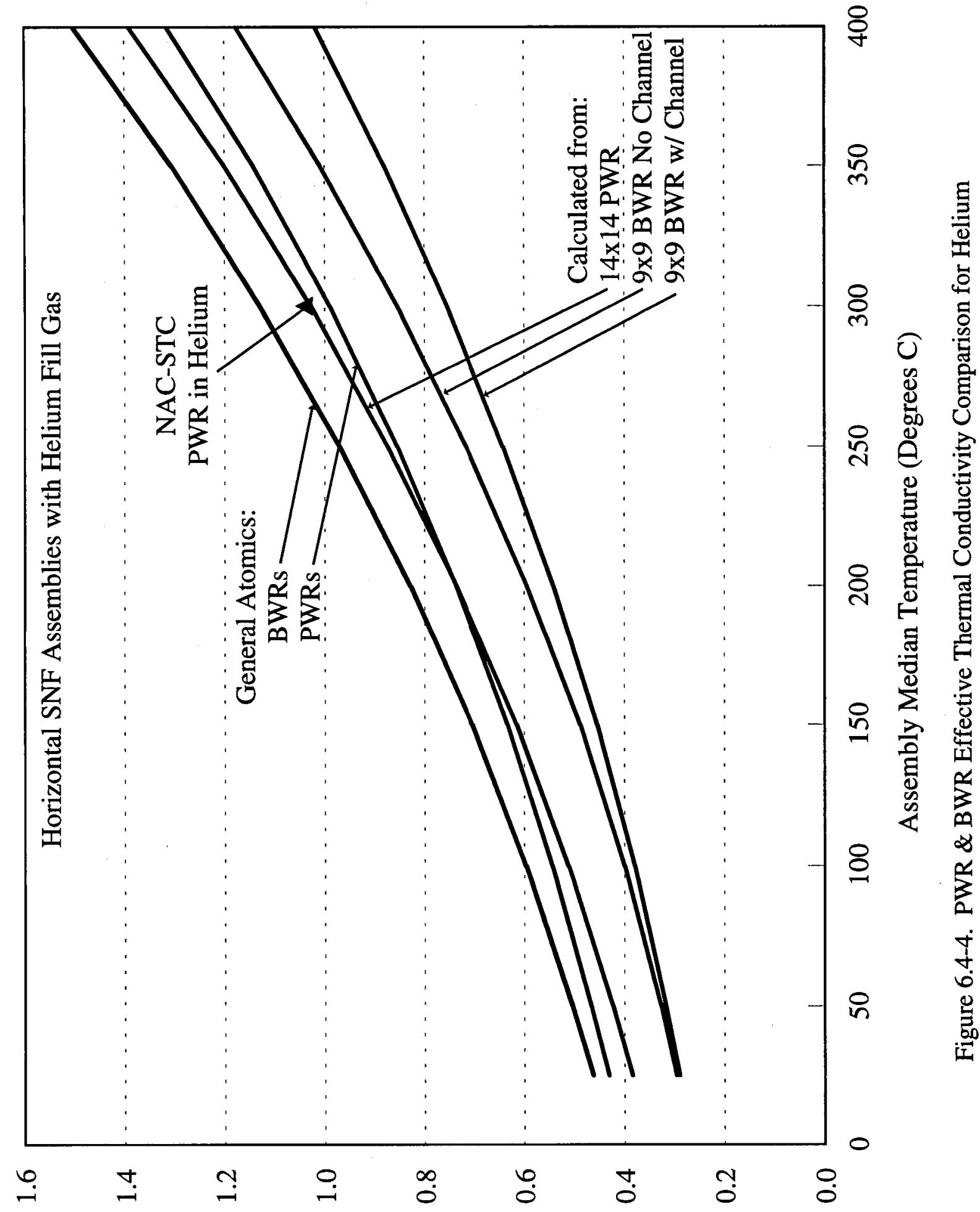

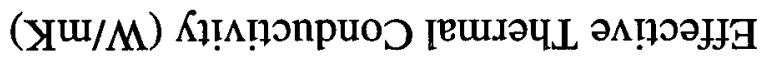




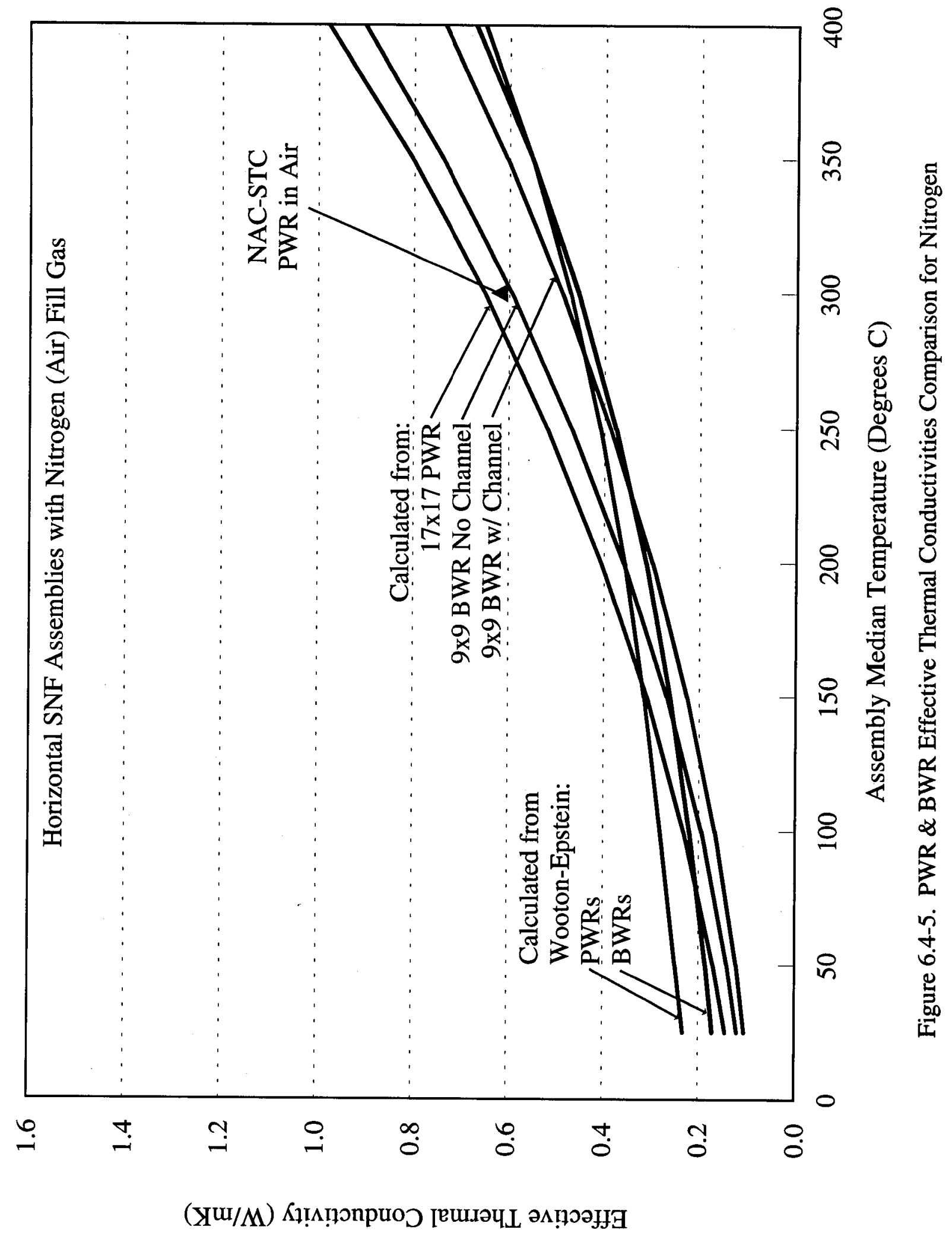


The comparisons between PWR and BWR effective thermal conductivities (Figures 6.4-4 and 6.4-5) show the BWR conductivities to be lower than those for PWR assemblies. However, there is an expectation that peak cladding temperatures in the BWR assemblies should generally be lower than those experienced by PWR assemblies, and therefore the effective thermal conductivities for BWRs would be higher. Thus, the results of comparisons here appear to be counterintuitive. It is important to note, however, that the reason the BWR assemblies generally have lower peak temperatures than PWR assemblies is that BWR assemblies generally produce less heat. They are not necessarily better conductors of heat. In fact, the trending observed here indicates that for a highly conductive fill medium such as helium gas, sparser arrays of rods actually result in higher temperatures than for arrays with more rods when both assemblies generate the same amount of heat. Thus, BWR assemblies have lower effective thermal conductivities than the larger arrays of PWR assemblies (and yet still experience lower peak temperatures due to the lower heat generation rates). 
Spent Nuclear Fuel Effective Thermal Conductivity Report

DI: BBA000000-01717-5705-00010 REV 00

Page 118 of 154

INTENTIONALLY LEFT BLANK 


\section{Back Checks and Benchmarks}

The effective thermal conductivities developed in Section 6 are back checked and benchmarked in this section in three steps. First, to confirm that the effective thermal conductivities were defined correctly, solutions for smeared-property homogeneous models (using the effective thermal conductivity method) are compared to the results of the discrete SNF models of Section 4 for each temperature and SNF heat load considered. Then, effective thermal conductivity and SNF model predictions are compared to single assembly temperatures reported in SNF storage cask testing reports. ${ }^{[23,20]}$ Finally, the use and accuracy of the effective thermal conductivity method is evaluated in a half-cask benchmark against performance tests for the TN-24P storage cask. ${ }^{[23]}$

\subsection{Back Check of Effective Thermal Conductivity}

To perform a simple check of the development of the SNF effective thermal conductivities in Section 6, ANSYS models of homogeneous SNF assemblies were created and evaluated over the same range of temperatures and heat loads used with the discrete SNF models. The back check performed in this section also demonstrates the use of the effective thermal conductivity method for predicting peak cladding temperatures using a smeared-property homogeneous model of an SNF assembly. For PWR assemblies, homogeneous models of the $17 \times 17,15 \times 15$, and $14 \times 14$ arrays in fill environments of helium, vacuum, nitrogen, and argon were considered. For BWR assemblies, homogeneous models of the $9 \times 9,8 \times 8$, and $7 \times 7$ arrays with and without an 80 mil channel in fill environments of helium, vacuum, nitrogen, and argon were considered. Predicted peak temperatures from each homogeneous model (using the appropriate effective thermal conductivity) are compared to the peak cladding temperatures calculated in Section 4.

\subsubsection{PWR Assembly Geometries}

Using the same basket cell width, active length, and peaking factor described in Section 3 for each PWR assembly type, a homogeneous assembly model was developed with smeared material properties representing the assembly area (similar to how it may be done in future waste package thermal evaluations). A square grid (14 by 14) of elements was modeled in the smeared property assembly area. Smeared values for density and specific heat were also assumed; ${ }^{[48]}$ however, for a steady-state analysis as performed here, these two values are unimportant to the calculations.

Each PWR homogeneous model was evaluated over the same range of heat loads and temperatures used in Section 4. As a representative case, a comparison of the difference between the results of the $17 \times 17$ PWR SNF assembly model in a vacuum (from Section 4) and the homogeneous assembly is provided in Table 7.1-1. The greatest differences were observed for the vacuum case (bounding the differences found for the other fill environments); the best correlation was observed for the helium fill gas for all three PWR assembly designs. Table 7.1-2 lists the magnitude (absolute value) of the maximum deviation for each of the cases considered. In every comparison, the maximum difference between the discrete and homogeneous models occurred for the highest heat load and highest temperature case, and was always less than $1.5^{\circ} \mathrm{C}$. Further, in the range of temperatures and assembly heat loads where cladding temperatures may be near limits for disposal, the differences were generally within $0.2^{\circ} \mathrm{C}$. 
The homogeneous model results indicate the ability of the effective thermal conductivity methodology used with finite element codes to predict "best estimate" cladding temperatures in an SNF assembly. The homogeneous model results were very close to the discrete model results; homogeneous predictions were slightly higher for high temperatures, and slightly lower for low temperatures. Any trending which can be seen in the temperature differences with respect to basket wall temperature and heat load is strongly correlated with the curve fit used to generate the effective thermal conductivities for finite element analyses. Also, the accuracy and convergence of the calculation is such that the results of the discrete SNF models and the homogeneous models are not significantly different (i.e., essentially identical).

Table 7.1-1. Peak Temperature Difference (17x17 PWR in Vacuum vs. Hom. Model)

\begin{tabular}{||c||c|c|c|c||}
\hline \multirow{2}{*}{$\begin{array}{c}\text { Basket Wall } \\
\text { Temperature }\end{array}$} & \multicolumn{4}{|c|}{ Assembly Heat Load } \\
\cline { 2 - 5 } & 250 watts & 500 watts & 750 watts & 1000 watts \\
\hline $25^{\circ} \mathrm{C}$ & $1.1^{\circ} \mathrm{C}$ & $1.3^{\circ} \mathrm{C}$ & $1.2^{\circ} \mathrm{C}$ & $1.0^{\circ} \mathrm{C}$ \\
\hline $50^{\circ} \mathrm{C}$ & $0.9^{\circ} \mathrm{C}$ & $0.9^{\circ} \mathrm{C}$ & $0.8^{\circ} \mathrm{C}$ & $1.1^{\circ} \mathrm{C}$ \\
\hline $100^{\circ} \mathrm{C}$ & $0.4^{\circ} \mathrm{C}$ & $0.5^{\circ} \mathrm{C}$ & $0.5^{\circ} \mathrm{C}$ & $0.5^{\circ} \mathrm{C}$ \\
\hline $150^{\circ} \mathrm{C}$ & $0.1^{\circ} \mathrm{C}$ & $0.3^{\circ} \mathrm{C}$ & $0.4^{\circ} \mathrm{C}$ & $0.3^{\circ} \mathrm{C}$ \\
\hline $200^{\circ} \mathrm{C}$ & $0.0^{\circ} \mathrm{C}$ & $0.1^{\circ} \mathrm{C}$ & $0.2^{\circ} \mathrm{C}$ & $0.2^{\circ} \mathrm{C}$ \\
\hline $250^{\circ} \mathrm{C}$ & $0.0^{\circ} \mathrm{C}$ & $0.0^{\circ} \mathrm{C}$ & $0.0^{\circ} \mathrm{C}$ & $0.0^{\circ} \mathrm{C}$ \\
\hline $300^{\circ} \mathrm{C}$ & $0.0^{\circ} \mathrm{C}$ & $0.0^{\circ} \mathrm{C}$ & $0.0^{\circ} \mathrm{C}$ & $0.0^{\circ} \mathrm{C}$ \\
\hline $350^{\circ} \mathrm{C}$ & $0.0^{\circ} \mathrm{C}$ & $0.0^{\circ} \mathrm{C}$ & $0.0^{\circ} \mathrm{C}$ & $0.0^{\circ} \mathrm{C}$ \\
\hline $400^{\circ} \mathrm{C}$ & $-0.1^{\circ} \mathrm{C}$ & $-0.4^{\circ} \mathrm{C}$ & $-0.8^{\circ} \mathrm{C}$ & $-1.4^{\circ} \mathrm{C}$ \\
\hline
\end{tabular}

Table 7.1-2. Maximum Temperature Difference for Homogeneous PWR Back Check

\begin{tabular}{||c||c|c|c|c||}
\hline \multirow{2}{*||}{ PWR Assembly Model } & \multicolumn{4}{|c||}{ Magnitude of Maximum Temperature Difference } \\
\cline { 2 - 5 } & Helium & Vacuum & Nitrogen & Argon \\
\hline \hline $17 \times 17 \mathrm{PWR}$ & $0.4^{\circ} \mathrm{C}$ & $1.4^{\circ} \mathrm{C}$ & $1.1^{\circ} \mathrm{C}$ & $1.2^{\circ} \mathrm{C}$ \\
\hline $15 \times 15 \mathrm{PWR}$ & $0.4^{\circ} \mathrm{C}$ & $1.2^{\circ} \mathrm{C}$ & $0.9^{\circ} \mathrm{C}$ & $1.0^{\circ} \mathrm{C}$ \\
\hline $14 \times 14 \mathrm{PWR}$ & $0.5^{\circ} \mathrm{C}$ & $1.4^{\circ} \mathrm{C}$ & $1.1^{\circ} \mathrm{C}$ & $1.2^{\circ} \mathrm{C}$ \\
\hline
\end{tabular}


Care should be taken not to extrapolate the effective thermal conductivity results to alternate assembly configurations (such as consolidated assemblies) or alternate fill gases for which calculations have not been completed at this time. As can be seen by the data presented in Sections 4,5 , and 6 , small changes in the effective thermal conductivity values may have a significant effect on the peak cladding temperatures which are predicted.

Another issue which needs to be addressed is the question of the minimum mesh density required in order to maintain the accuracy of the finite element effective thermal conductivity. In order to assess this requirement, ANSYS inputs were generated which used the homogeneous $17 \times 17$ PWR model geometry for the vacuum environment with a $2 \times 2,4 \times 4,6 \times 6,8 \times 8,10 \times 10,12 \times 12,14 \times 14$, $16 \times 16,18 \times 18$, and $20 \times 20$ mesh density for the SNF material region to determine the required minimum mesh density to obtain the desired level of accuracy.

The selection of a mesh density is strongly dependent upon the expected thermal gradients in the region to be meshed and is therefore very problem dependent. However, for the relatively mild thermal gradients encountered for the homogeneous models, it is still very instructive to determine the mesh density at which the solution results do not significantly change. Since the gradients which are being examined are relatively mild, the selected mesh density would be the minimum acceptable mesh density for any problem. The vacuum environment was selected for this mesh density parametric because it displays the largest thermal gradient (compared to the other fill environments considered). Use of the vacuum environment minimum mesh density for any other fill gas environment should not impose any significant calculational penalty and therefore shall represent the minimum mesh density for all effective thermal conductivity formulations for PWR SNF.

The solution results show that for mesh densities greater than $14 \times 14$, model results are reasonably consistent, although some small differences due to convergence criteria and solution path are noticeable. The results for mesh densities much less than $14 \times 14$ are clearly changing rapidly and, thus, are inadequate for the problem being analyzed. Thus, it is reasonable to require a minimum $14 \times 14$ mesh density with the use of the PWR effective thermal conductivity method. If larger gradients than those analyzed in this report are expected, then the mesh density should be increased in order to maintain the accuracy of the method.

\subsubsection{BWR Assembly Geometries}

Using the same basket cell width, active length, and peaking factor described in Section 3 for each BWR assembly type (with and without a channel), a homogeneous assembly model was developed with smeared material properties representing the assembly area (similar to how it may be done in future waste package thermal evaluations). A square grid (10 by 10) of elements was modeled in the smeared property assembly area. Smeared values for density and specific heat were also assumed; ${ }^{[49]}$ however, for a steady-state analysis, these two values are unimportant to the calculations here.

Each BWR homogeneous model was evaluated over the same range of heat loads and temperatures as used in Section 4. As a representative case, a comparison of the difference between the results of the 9x9 BWR SNF assembly model with an 80 mil channel in a vacuum (from Section 4) and the 
homogeneous assembly is provided in Table 7.1-3. The greatest differences were observed for the vacuum case (bounding the differences found for the other fill environments); the best correlation was observed for the helium fill gas for all of the BWR assembly design configurations. Table 7.1-4 lists the magnitude (absolute value) of the maximum deviation for each of the cases considered. In most of the comparisons, the maximum difference between the discrete and homogeneous models occurred for the highest heat load and highest temperature case, and was always less than $1.3^{\circ} \mathrm{C}$. Further, in the range of temperatures and assembly heat loads where cladding temperatures may be near limits for disposal, the differences were generally within $0.2^{\circ} \mathrm{C}$.

Table 7.1-3. Peak Temperature Difference (9x9 BWR in Vacuum vs. Hom. Model)

\begin{tabular}{||c||c|c|c|c|c|c||}
\hline \multirow{2}{*}{$\begin{array}{c}\text { Basket Wall } \\
\text { Temperature }\end{array}$} & \multicolumn{7}{|c||}{ Assembly Heat Load } \\
\cline { 2 - 7 } & 100 watts & 200 watts & 300 watts & 400 watts & 500 watts & 600 watts \\
\hline \hline $25^{\circ} \mathrm{C}$ & $1.0^{\circ} \mathrm{C}$ & $0.8^{\circ} \mathrm{C}$ & $0.4^{\circ} \mathrm{C}$ & $0.0^{\circ} \mathrm{C}$ & $-0.4^{\circ} \mathrm{C}$ & $-0.7^{\circ} \mathrm{C}$ \\
\hline $50^{\circ} \mathrm{C}$ & $0.2^{\circ} \mathrm{C}$ & $0.0^{\circ} \mathrm{C}$ & $-0.2^{\circ} \mathrm{C}$ & $-0.5^{\circ} \mathrm{C}$ & $-0.7^{\circ} \mathrm{C}$ & $-0.9^{\circ} \mathrm{C}$ \\
\hline $100^{\circ} \mathrm{C}$ & $-0.1^{\circ} \mathrm{C}$ & $-0.3^{\circ} \mathrm{C}$ & $-0.4^{\circ} \mathrm{C}$ & $-0.5^{\circ} \mathrm{C}$ & $-0.5^{\circ} \mathrm{C}$ & $-0.8^{\circ} \mathrm{C}$ \\
\hline $150^{\circ} \mathrm{C}$ & $-0.1^{\circ} \mathrm{C}$ & $-0.2^{\circ} \mathrm{C}$ & $-0.3^{\circ} \mathrm{C}$ & $-0.3^{\circ} \mathrm{C}$ & $-0.4^{\circ} \mathrm{C}$ & $-0.4^{\circ} \mathrm{C}$ \\
\hline $200^{\circ} \mathrm{C}$ & $0.0^{\circ} \mathrm{C}$ & $-0.1^{\circ} \mathrm{C}$ & $-0.1^{\circ} \mathrm{C}$ & $-0.1^{\circ} \mathrm{C}$ & $-0.1^{\circ} \mathrm{C}$ & $-0.1^{\circ} \mathrm{C}$ \\
\hline $250^{\circ} \mathrm{C}$ & $0.0^{\circ} \mathrm{C}$ & $0.0^{\circ} \mathrm{C}$ & $0.0^{\circ} \mathrm{C}$ & $-0.1^{\circ} \mathrm{C}$ & $-0.1^{\circ} \mathrm{C}$ & $-0.1^{\circ} \mathrm{C}$ \\
\hline $300^{\circ} \mathrm{C}$ & $0.0^{\circ} \mathrm{C}$ & $0.0^{\circ} \mathrm{C}$ & $-0.1^{\circ} \mathrm{C}$ & $-0.1^{\circ} \mathrm{C}$ & $-0.1^{\circ} \mathrm{C}$ & $-0.1^{\circ} \mathrm{C}$ \\
\hline $350^{\circ} \mathrm{C}$ & $0.0^{\circ} \mathrm{C}$ & $-0.1^{\circ} \mathrm{C}$ & $-0.1^{\circ} \mathrm{C}$ & $-0.1{ }^{\circ} \mathrm{C}$ & $-0.1^{\circ} \mathrm{C}$ & $-0.2^{\circ} \mathrm{C}$ \\
\hline $400^{\circ} \mathrm{C}$ & $-0.1^{\circ} \mathrm{C}$ & $-0.2^{\circ} \mathrm{C}$ & $-0.3^{\circ} \mathrm{C}$ & $-0.6^{\circ} \mathrm{C}$ & $-0.8^{\circ} \mathrm{C}$ & $-1.1^{\circ} \mathrm{C}$ \\
\hline
\end{tabular}

Table 7.1-4. Maximum Temperature Difference for Homogeneous BWR Back Check

\begin{tabular}{||c||c|c|c|c||}
\hline \multirow{2}{*}{ BWR Assembly Model } & \multicolumn{4}{|c||}{ Magnitude of Maximum Temperature Difference } \\
\cline { 2 - 5 } & Helium & Vacuum & Nitrogen & Argon \\
\hline \hline 9x9 BWR with Channel & $0.4^{\circ} \mathrm{C}$ & $1.1^{\circ} \mathrm{C}$ & $1.0^{\circ} \mathrm{C}$ & $1.1^{\circ} \mathrm{C}$ \\
\hline 9x9 BWR No Channel & $0.3^{\circ} \mathrm{C}$ & $1.0^{\circ} \mathrm{C}$ & $0.7^{\circ} \mathrm{C}$ & $0.7^{\circ} \mathrm{C}$ \\
\hline $8 \times 8$ BWR with Channel & $0.4^{\circ} \mathrm{C}$ & $1.1^{\circ} \mathrm{C}$ & $0.9^{\circ} \mathrm{C}$ & $1.0^{\circ} \mathrm{C}$ \\
\hline $8 \times 8$ BWR No Channel & $0.3^{\circ} \mathrm{C}$ & $0.9^{\circ} \mathrm{C}$ & $0.6^{\circ} \mathrm{C}$ & $0.6^{\circ} \mathrm{C}$ \\
\hline $7 \times 7$ BWR with Channel & $0.4^{\circ} \mathrm{C}$ & $0.9^{\circ} \mathrm{C}$ & $1.2^{\circ} \mathrm{C}$ & $0.8^{\circ} \mathrm{C}$ \\
\hline $7 \times 7$ BWR No Channel & $0.3^{\circ} \mathrm{C}$ & $0.6^{\circ} \mathrm{C}$ & $0.4^{\circ} \mathrm{C}$ & $0.5^{\circ} \mathrm{C}$ \\
\hline
\end{tabular}


The homogeneous model results indicate the ability of the effective thermal conductivity methodology used with finite element codes to predict "best estimate" cladding temperatures in an SNF assembly. The homogeneous model results also show that for normal container design conditions, the peak cladding temperatures were consistently predicted to be slightly conservative. Any trending which can be seen in the temperature differences with respect to basket wall temperature and heat load is strongly correlated with the curve fit used to generate the effective thermal conductivities for finite element analyses. Also, the accuracy and convergence of the calculation is such that the results of the discrete SNF models and the homogeneous models are not significantly different (i.e., essentially identical).

As for the PWR assemblies, care should be taken not to extrapolate the BWR effective thermal conductivity results to alternate assembly configurations (such as consolidated assemblies) or alternate fill gases for which calculations have not been completed at this time. As can be seen by the data presented in Sections 4, 5, and 6, small changes in the effective thermal conductivity values may have a significant effect on the peak cladding temperatures which are predicted.

In order to assess the question of the minimum mesh density for the finite element effective thermal conductivity, ANSYS inputs were generated which used the homogeneous $7 \times 7$ BWR model geometry for the vacuum environment with a $2 \times 2,4 \times 4,6 \times 6,8 \times 8,10 \times 10,12 \times 12$, and $14 \times 14$ mesh density for the SNF material region to determine the required minimum mesh density to obtain the desired level of accuracy. For the relatively mild thermal gradients encountered for the homogeneous models, it is still very instructive to determine the mesh density at which the solution results do not significantly change (which would be the minimum acceptable mesh density for any problem). The vacuum environment with a channel was selected for this mesh density parametric because it displays the largest thermal gradient (compared to the other fill environments considered). Use of the vacuum environment minimum mesh density for any other fill gas environment should not impose any significant calculational penalty and therefore shall represent the minimum mesh density for all effective thermal conductivity formulations for BWR SNF.

The solution results show that for mesh densities greater than $8 \times 8$, model results are reasonably consistent, although some small differences due to convergence criteria and solution path are noticeable. The results for mesh densities less than $8 \times 8$ are clearly changing rapidly and thus, are inadequate for the problem being analyzed. The results at the $8 \times 8$ mesh density appear to be reasonable accurate; however, a small improvement is seen changing to the $10 \times 10$ mesh density. Thus, it is reasonable to require a minimum 10x10 mesh density with the use of the BWR effective thermal conductivity method. If larger gradients than those analyzed in this report are expected then the mesh density should be increased in order to maintain the accuracy of the method. 


\subsection{Model Benchmark Evaluations}

Several benchmarking evaluations have been performed against performance tests conducted at the Idaho National Engineering Laboratory (INEL) of the TN-24P PWR SNF storage cask ${ }^{[23]}$ and at the General Electric Morris Operation (GE-MO) facility of the REA 2023 BWR SNF storage cask. ${ }^{[20]}$ In the TN-24P test, 24 intact Westinghouse 15x15 PWR SNF assemblies were loaded into a PWR spent fuel storage cask at INEL. In the REA 2023 test, 52 intact GE 7x7 BWR SNF assemblies were loaded into a BWR spent fuel storage cask at GE-MO. For both tests, temperatures were measured with an array of thermocouples and compared to pre-test and post-test predictions with the COBRASFS and HYDRA-II heat transfer computer codes. These test results and model predictions are compared here to discrete SNF model and effective thermal conductivity results for a single assembly. These comparisons are also documented in further detail in the supporting design analyses. ${ }^{[4,49]}$

\subsubsection{Westinghouse $15 \times 15$ Model}

To perform the TN-24P benchmark, the 15x15 PWR SNF model described in Section 3.2.1 was modified to represent a Westinghouse $15 \times 15$ PWR assembly. ${ }^{[4]}$ Besides the slightly different assembly dimensions listed in Table 7.2-1, the Westinghouse assembly also has 20 guide tubes, compared to 16 for the B\&W assembly, and they are in different positions. To match the test as closely as possible, assembly dimensions of Table 7.2-1 were used, as well as a basket opening of $0.221 \mathrm{~m}^{[23]}$ and an assembly heat peaking factor of $1.26^{[23]}$

Table 7.2-1. Westinghouse 15x15 PWR Assembly Dimensions ${ }^{[4,12,48]}$

\begin{tabular}{|c|c|}
\hline Number of Rods & 204 \\
\hline Rod Pitch & $14.30 \mathrm{~mm}(0.563 \mathrm{in})$. \\
\hline UO $_{2}$ Pellet Diameter & $9.29 \mathrm{~mm}(0.3659 \mathrm{in})$. \\
\hline Cladding Outer Diameter & $10.72 \mathrm{~mm}(0.422 \mathrm{in})$. \\
\hline Cladding Thickness & $0.617 \mathrm{~mm}(0.0243 \mathrm{in})$. \\
\hline Number of Guide Tubes & 20 \\
\hline Guide Tube Outer Diameter & $13.87 \mathrm{~mm}(0.546 \mathrm{in})$. \\
\hline Guide Tube Thickness & $0.432 \mathrm{~mm}(0.017 \mathrm{in})$. \\
\hline Instrument Tube Outer Diameter & $13.87 \mathrm{~mm}(0.546 \mathrm{in})$. \\
\hline Instrument Tube Thickness & $0.432 \mathrm{~mm}(0.017 \mathrm{in.})$ \\
\hline Active Fuel Length & $3657.6 \mathrm{~mm}(144.0 \mathrm{in})$. \\
\hline
\end{tabular}




\subsubsection{Comparisons to TN-24P Storage Cask Tests}

Presented here are the results of a benchmark of the discrete SNF model against three of the assemblies in the performance tests of the TN-24P with helium, vacuum, and nitrogen fill environments in a horizontal configuration. Three assemblies from the TN-24P test were chosen for this benchmark as they have both basket and guide tube thermocouple measurements provided in the test report appendix. ${ }^{[23]}$ No thermocouple data for peak cladding temperatures were provided in the reference; only basket and guide tube measurements and computer simulations of cladding temperatures are provided. The chosen assembly positions are identified as D1, D5, and A1 in TN24P Figure 3-17. ${ }^{[23]}$

Since the ANSYS model is a 2-D slice of an assembly, we are interested in temperatures near the axial mid-length of the cask where temperatures are highest (an axial location of about $2.3 \mathrm{~m}$ ). The basket and assembly thermocouples at the axial mid-length and the positions of assemblies D1, D5, and A1 are displayed graphically here in Figure 7.2-1. The thermocouples near the axial mid-length and reported temperatures corresponding to the SNF basket near D1, D5, and A1 are listed below in Table 7.2-2. These basket temperatures are applied as the boundary condition for each assembly comparison evaluation.

Table 7.2-2. TN-24P Basket Thermocouple Temperatures at Axial Mid-Length ${ }^{[23]}$

\begin{tabular}{||c||cc||c|c|c||}
\hline \multirow{2}{*}{ Assembly } & \multicolumn{2}{|c||}{ Position } & Thermocouple & \multicolumn{3}{c||}{ Temperature During Test } \\
\cline { 5 - 6 } & & Horizontal & $\begin{array}{c}\text { Horizontal } \\
\text { Nitrogen }\end{array}$ & $\begin{array}{c}\text { Horizontal } \\
\text { Vacuum }\end{array}$ \\
\hline \hline Position D1 & Center Basket & $\mathrm{TC} 107$ & $192.5^{\circ} \mathrm{C}$ & $222.9^{\circ} \mathrm{C}$ & $242.6^{\circ} \mathrm{C}$ \\
\hline Position D5 & Outer Basket & $\mathrm{TC} 105$ & $127.3^{\circ} \mathrm{C}$ & $147.4^{\circ} \mathrm{C}$ & $176.3^{\circ} \mathrm{C}$ \\
\hline Position A1 & Center Basket & $\mathrm{TC} 107$ & $192.5^{\circ} \mathrm{C}$ & $222.9^{\circ} \mathrm{C}$ & $242.6^{\circ} \mathrm{C}$ \\
\hline
\end{tabular}

The assembly heat outputs for each of the test assemblies, reported for the beginning and ending dates, are provided in Table 3-3 of the TN-24P report. ${ }^{[23]}$ The two dates correspond to the first experiment performed (vertical cask with helium fill gas) and the last experiment performed (horizontal cask with a vacuum). The individual assembly heat loads for the other experiments can be roughly estimated by linear interpolation using the dates reported for each test. Table 7.2-3 provides the results of the heat determination. The heat loads for the TN-24P cask in a horizontal orientation with fill environments of helium, nitrogen, and vacuum were considered in this evaluation. 


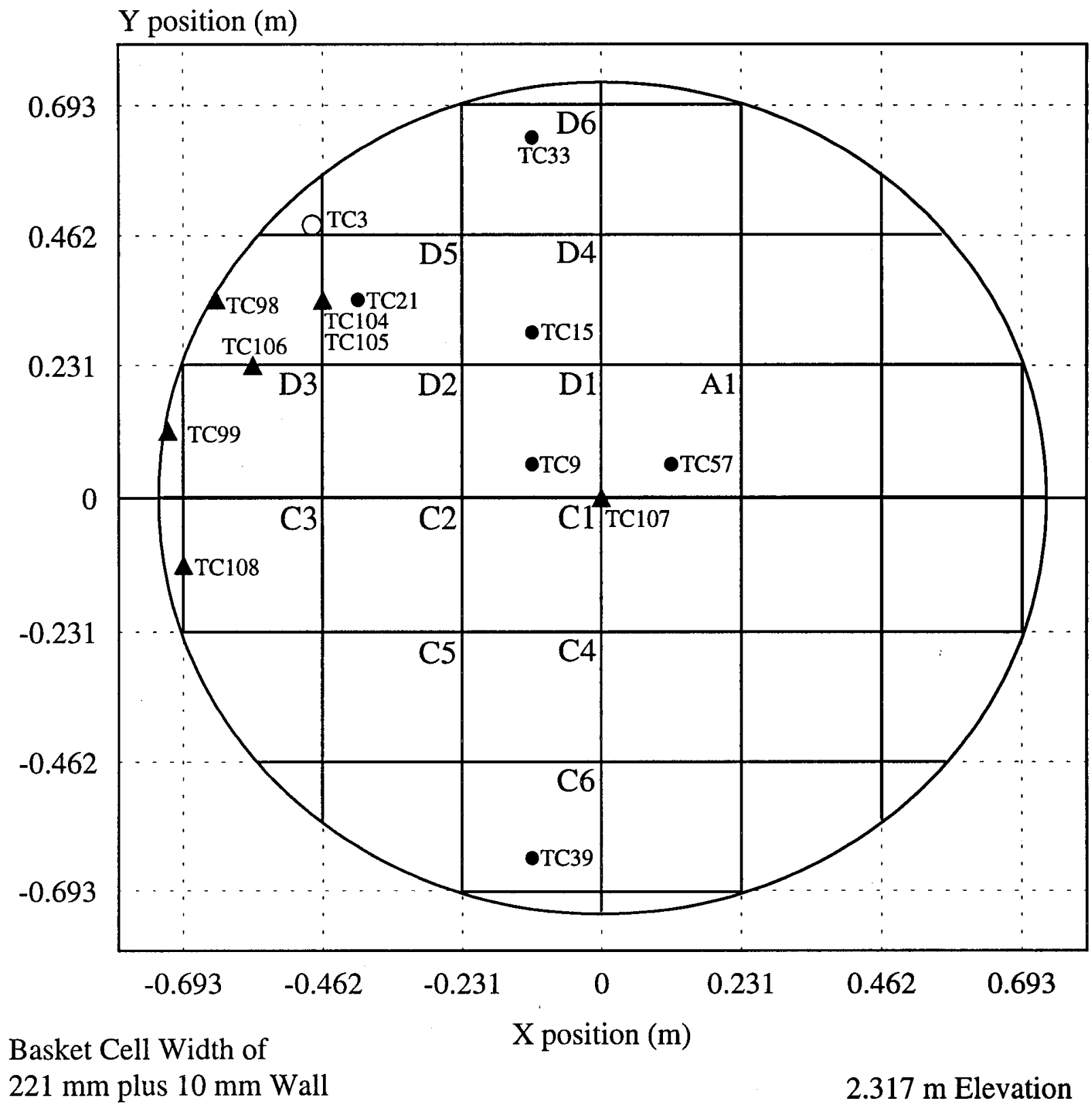

Figure 7.2-1. Basket and Assembly Thermocouple Locations for the TN-24P Test 
Table 7.2-3. TN-24P Assembly Heat Outputs ${ }^{[23]}$

\begin{tabular}{||c|c|c|c|c||}
\hline \multirow{2}{*}{ Assembly } & $\begin{array}{c}\text { Vertical } \\
\text { Helium }\end{array}$ & $\begin{array}{c}\text { Horizontal } \\
\text { Helium }\end{array}$ & $\begin{array}{c}\text { Horizontal } \\
\text { Nitrogen }\end{array}$ & $\begin{array}{c}\text { Horizontal } \\
\text { Vacuum }\end{array}$ \\
\cline { 2 - 5 } & $\begin{array}{c}01 / 14 / 86 \\
\text { Start }\end{array}$ & $01 / 27 / 86$ & $01 / 31 / 86$ & $\begin{array}{c}02 / 06 / 86 \\
\text { End }\end{array}$ \\
\hline \hline $\begin{array}{c}\text { Position D1 } \\
\text { ID Number V18 }\end{array}$ & 919.2 watts & 911.2 watts & 908.7 watts & 905.0 watts \\
\hline $\begin{array}{c}\text { Position D5 } \\
\text { ID Number V16 }\end{array}$ & 870.0 watts & 862.4 watts & 860.0 watts & 856.5 watts \\
\hline $\begin{array}{c}\text { Position A1 } \\
\text { ID Number V03 }\end{array}$ & 870.0 watts & 862.4 watts & 860.0 watts & 856.5 watts \\
\hline
\end{tabular}

For each of the benchmark assemblies, the basket temperature (used as an edge boundary condition) and assembly heat load were applied to the Westinghouse $15 \times 15$ SNF model described in Section 7.1. Figure 7.2-2 displays a sample temperature contour plot (in degrees C) for the helium benchmark case (assembly position D1) with basket temperature from TC107 and heat load from assembly V18 (the hottest case). To complete the benchmark, calculated guide tube temperatures are compared to those measured in the TN-24P test. Measured and calculated guide tube temperatures as well as predictions of cladding temperature are compared in Table 7.2-4. Guide tube temperatures for the discrete SNF assembly model are reported as an average of six points around the guide tubes in positions 5 and 6 (which are located at planes of symmetry in the SNF model). For assembly position D1, guide tube and peak cladding temperatures predicted by the SNF model are compared to pre-test predictions performed by Pacific Northwest Laboratory (PNL) using the COBRA-SFS code as part of the TN-24P testing (estimated from TN-24P Figure 5-18 ${ }^{[23]}$ ).

Additional calculations of estimated peak cladding temperature were also performed using the effective thermal conductivities calculated in Section 6 and the Wooton-Epstein ${ }^{[5]}$ correlation. To determine the peak cladding temperature as estimated by the effective thermal conductivity method, effective thermal conductivities (for each appropriate fill environment) were interpolated from the effective thermal conductivity results of the $15 \times 15$ PWR assembly ${ }^{[48]}$ based on the basket temperatures of Table 7.2-2. To match test conditions as closely as possible (and to show that the effective thermal conductivity method is a good "best estimate" tool), the effective thermal conductivities for a $15 \times 15$ assembly ${ }^{[48]}$ were assumed instead of the more conservative values for the $17 \times 17$ array (as recommended in Table 6.2-1). Then, using Equation 6.1-5, the peak cladding temperatures were solved analytically (to represent a typical use of the effective thermal conductivity in a canister analysis). The Wooton-Epstein correlation was used as described in Section 5 with the assembly and basket dimensions of Table 4.2-1. 
Table 7.2-4. TN-24P Benchmark Temperature Comparisons

\begin{tabular}{|c|c|c|c|c|}
\hline Assembly & Result and Source & $\begin{array}{c}\text { Horizontal } \\
\text { Helium }\end{array}$ & $\begin{array}{c}\text { Horizontal } \\
\text { Nitrogen }\end{array}$ & $\begin{array}{c}\text { Horizontal } \\
\text { Vacuum }\end{array}$ \\
\hline \multirow{7}{*}{$\begin{array}{c}\text { Position D1 } \\
\text { ID Number V18 }\end{array}$} & Measured Guide Tube (TC9) & $206^{\circ} \mathrm{C}$ & $246^{\circ} \mathrm{C}$ & $266^{\circ} \mathrm{C}$ \\
\hline & COBRA-SFS Guide Tube & $216^{\circ} \mathrm{C}$ & $253^{\circ} \mathrm{C}$ & $260^{\circ} \mathrm{C}$ \\
\hline & SNF Model Guide Tube & $215^{\circ} \mathrm{C}$ & $256^{\circ} \mathrm{C}$ & $277^{\circ} \mathrm{C}$ \\
\hline & COBRA-SFS Peak Cladding & $222^{\circ} \mathrm{C}$ & $263^{\circ} \mathrm{C}$ & $270^{\circ} \mathrm{C}$ \\
\hline & SNF Model Peak Cladding & $221^{\circ} \mathrm{C}$ & $265^{\circ} \mathrm{C}$ & $287^{\circ} \mathrm{C}$ \\
\hline & Effective Conductivity Peak Cladding & $221^{\circ} \mathrm{C}$ & $266^{\circ} \mathrm{C}$ & $288^{\circ} \mathrm{C}$ \\
\hline & Wooton-Epstein Peak Cladding & $248^{\circ} \mathrm{C}$ & $274^{\circ} \mathrm{C}$ & $291^{\circ} \mathrm{C}$ \\
\hline \multirow{5}{*}{$\begin{array}{c}\text { Position D5 } \\
\text { ID Number V16 }\end{array}$} & Measured Guide Tube (TC21) & $173^{\circ} \mathrm{C}$ & $211^{\circ} \mathrm{C}$ & $229^{\circ} \mathrm{C}$ \\
\hline & SNF Model Guide Tube & $153^{\circ} \mathrm{C}$ & $192^{\circ} \mathrm{C}$ & $223^{\circ} \mathrm{C}$ \\
\hline & SNF Model Peak Cladding & $160^{\circ} \mathrm{C}$ & $204^{\circ} \mathrm{C}$ & $235^{\circ} \mathrm{C}$ \\
\hline & Effective Conductivity Peak Cladding & $161^{\circ} \mathrm{C}$ & $206^{\circ} \mathrm{C}$ & $237^{\circ} \mathrm{C}$ \\
\hline & Wooton-Epstein Peak Cladding & $189^{\circ} \mathrm{C}$ & $206^{\circ} \mathrm{C}$ & $231^{\circ} \mathrm{C}$ \\
\hline \multirow{5}{*}{$\begin{array}{c}\text { Position A1 } \\
\text { ID Number V03 }\end{array}$} & Measured Guide Tube (TC57) & $208^{\circ} \mathrm{C}$ & $248^{\circ} \mathrm{C}$ & $268^{\circ} \mathrm{C}$ \\
\hline & SNF Model Guide Tube & $214^{\circ} \mathrm{C}$ & $254^{\circ} \mathrm{C}$ & $276^{\circ} \mathrm{C}$ \\
\hline & SNF Model Peak Cladding & $220^{\circ} \mathrm{C}$ & $263^{\circ} \mathrm{C}$ & $285^{\circ} \mathrm{C}$ \\
\hline & Effective Conductivity Peak Cladding & $220^{\circ} \mathrm{C}$ & $263^{\circ} \mathrm{C}$ & $286^{\circ} \mathrm{C}$ \\
\hline & Wooton-Epstein Peak Cladding & $245^{\circ} \mathrm{C}$ & $271^{\circ} \mathrm{C}$ & $288^{\circ} \mathrm{C}$ \\
\hline
\end{tabular}

Table 7.2-4 demonstrates, again, the best estimate prediction with the SNF assembly model in a helium fill gas compared to conservative temperature predictions with the Wooton-Epstein correlation. For assembly position D1 in the helium fill gas, both the COBRA-SFS pre-test and the discrete SNF model slightly over-predicted guide tube temperatures compared to the thermocouple data reported (by about $10^{\circ} \mathrm{C}$ ). Assembly temperatures predicted by the COBRA-SFS were closely matched by the discrete SNF assembly model, and the effective thermal conductivity solution was identical or slightly higher than the assembly model. This same trending was observed for the comparison with the nitrogen fill gas. As expected, the Wooton-Epstein solution (which was developed for assemblies in air) predicted temperatures only somewhat higher than the other prediction methods in nitrogen. 
章U n

NHm

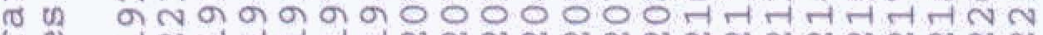

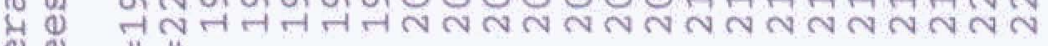

(4) (1) II H

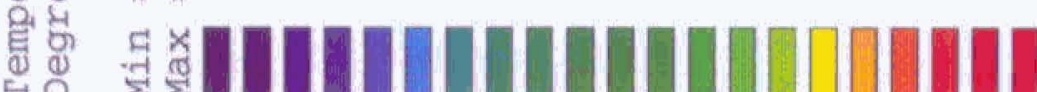

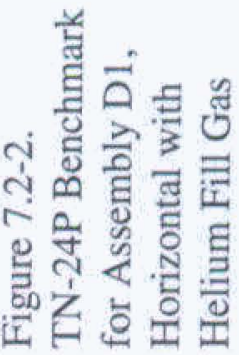

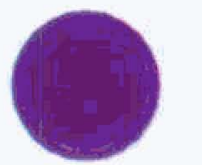
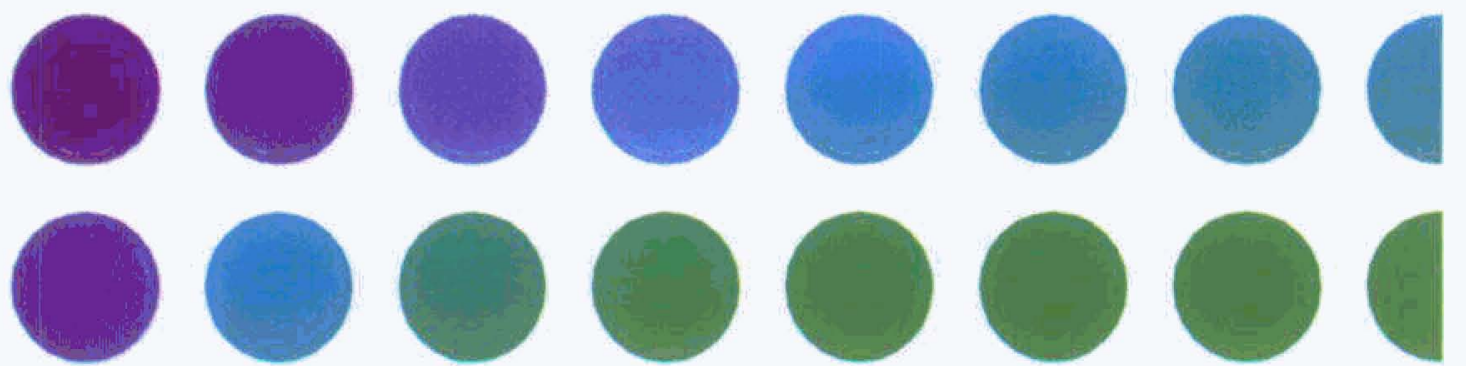

4
4
$\frac{1}{4}$
0
0
0
0
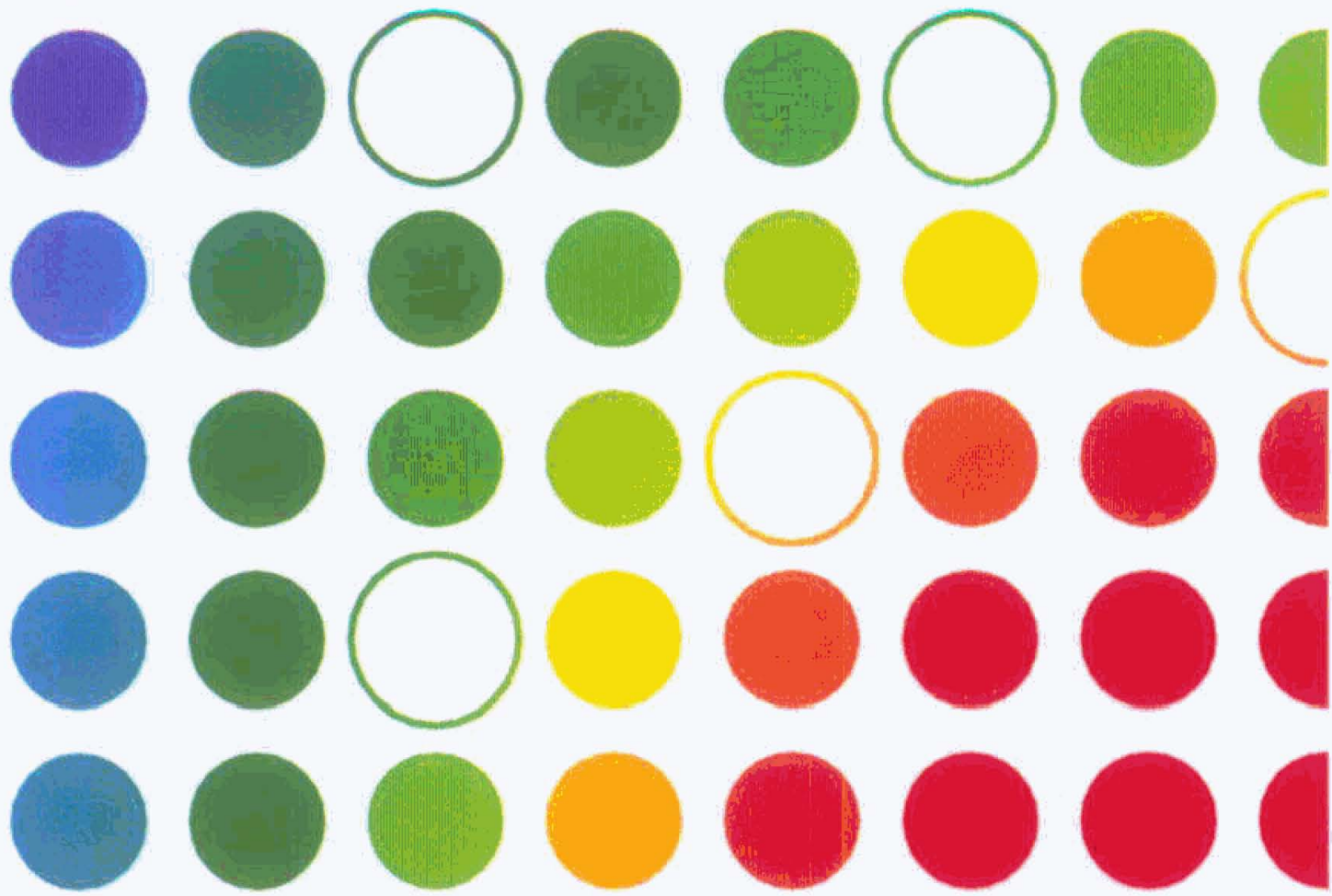

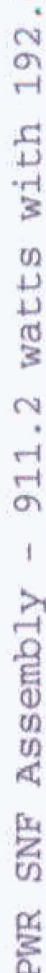
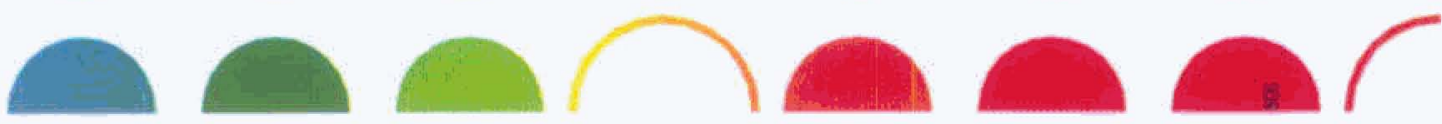
For the comparison of assembly position D1 in a vacuum, the discrete SNF model again predicted about $10^{\circ} \mathrm{C}$ higher than the measurements, and was matched closely by the effective thermal conductivity solution. However, the reported COBRA-SFS solution slightly under-predicted temperatures in this assembly. As expected from the trending in Figure 6.2-2, the Wooton-Epstein solution was only slightly higher than the effective thermal conductivity solution in a vacuum.

For assembly position D5, the discrete SNF model and the effective thermal conductivity predicted temperatures somewhat below the thermocouple measurements. This difference is an expected result considering the assumption of a uniform basket temperature around the SNF model. For assembly positions D1 and A1, the basket thermocouple is in the center of the SNF basket where radial basket temperature gradients are flattest. The basket thermocouple near D5, however, is near the canister wall and is likely not representative of average temperatures around that assembly. Thus, a low basket temperature measurement (assumed to be the SNF model boundary condition) resulted in a low guide tube and cladding prediction. However, if the effective thermal conductivity method were used in a full model of the TN-24P storage cask (see Section 7.3), a range of boundary temperatures would result around the assembly and predicted peak temperatures would be closer to values reported in the tests.

For assembly position $\mathrm{A} 1$, similar results and trending were seen compared to assembly position D1 and demonstrated the expected shift in temperatures due to the lower heat production in assembly V03 compared to assembly V18. In this case discrete SNF model predictions were about $6^{\circ} \mathrm{C}$ higher than thermocouple measurements and were matched closely by the effective thermal conductivity method results. Again, the Wooton-Epstein correlation significantly over-predicted temperatures only for the helium fill gas.

While no thermocouple data is available for peak cladding temperatures for this test, the discrete SNF model predicted cladding temperatures nearly identical to those predicted by the COBRA-SFS analysis for the fill gases of helium and nitrogen. For all three assemblies in helium, the WootonEpstein correlation (which does not really apply to helium fill gas) predicted temperatures more than $25^{\circ} \mathrm{C}$ higher. This benchmark test indicates that the SNF assembly model can accurately predict a "best estimate" of temperatures within a PWR assembly for helium, vacuum, and nitrogen fill environments (for at least the center of an SNF canister where basket thermal gradients are low); and, therefore, can be used to derive effective thermal conductivities (see Section 6) for use in thermal analyses of waste package designs in repository emplacement. Further, the effective thermal conductivities defined in this report provide cladding temperature predictions which are in adequate agreement with measurements. 


\subsubsection{Comparisons to REA 2023 Storage Cask Tests}

Presented here are the results of a benchmark of the SNF finite element effective thermal conductivity model (i.e., a homogeneous representation of a BWR SNF assembly in a single fuel tube as presented in Section 7.1) against two of the assemblies in the performance test of the REA 2023 storage cask with helium, nitrogen, and vacuum environments in both vertical and horizontal configurations. ${ }^{[20,21]}$ To perform this benchmark, the BWR effective thermal conductivities for finite element analysis, described in Section 6, for the GE-2 $7 \times 7$ assembly without channel ${ }^{[49]}$ were modeled as a homogeneous BWR assembly. In the REA 2023 storage cask tests, 52 GE-2 7x7 BWR assemblies with the channels removed were measured and loaded. To predict temperatures in this benchmark comparison as closely as possible (and to show that the effective thermal conductivity method is a good "best estimate" tool), the effective thermal conductivity for a 7x7 BWR assembly (provided in a supporting design analysis ${ }^{[49]}$ ) was used instead of the bounding (more conservative) 9x9 BWR results recommended in Section 6. Other GE-MO experiment conditions used here include an SNF basket opening of $0.1524 \mathrm{~m}$ (6.0 inches) $)^{[20]}$ and an axial power peaking factor of $1.20 .^{[21]}$

Two assemblies from the REA 2023 storage cask experiments were chosen for this benchmark as they have basket and center fuel rod cladding thermocouple measurements provided in the test report appendix, ${ }^{[20]}$ and they represent the center-of-cask and edge-of-cask conditions. The chosen assemblies are identified as CZ346 and CZ246 in positions 2J and 2G in the REA 2023 test report Figure 3.5. ${ }^{[21]}$ Thermocouple positions within the storage cask are displayed graphically in Figures 5.1, 5.2, and G.1 of the test report. ${ }^{[20]}$ Since the ANSYS model is a 2-D slice of a homogeneous assembly, we are interested in temperatures near the axial mid-length of the cask where temperatures are highest (an axial location of about $3.33 \mathrm{~m}$ ). The thermocouple data for the selected BWR assemblies at the desired radial and axial positions, corresponding to the BWR SNF basket wall and BWR assembly center rod cladding temperatures, for the modeled experiment runs $6 \mathrm{~B}, 7,10$, and $11 \mathrm{~A}$ are listed below in Table 7.2-5.

Table 7.2-5. REA 2023 Thermocouple Temperatures at Axial Mid-Length ${ }^{[20]}$

\begin{tabular}{||c|c|c|c||}
\hline \multirow{2}{*}{ Assembly } & $\begin{array}{c}\text { Thermocouple Radial } \\
\text { Position }\end{array}$ & Position Description & Temperature \\
\hline \hline $\begin{array}{l}\text { Run 6B Position 2J } \\
\text { ID Number CZ346 }\end{array}$ & $0.25 \mathrm{~m}$ & Tube Wall Between 2J \& 2G & $132.2^{\circ} \mathrm{C}$ \\
\cline { 2 - 4 } & $0.13 \mathrm{~m}$ & Center Rod Cladding & $172.8^{\circ} \mathrm{C}$ \\
\hline $\begin{array}{l}\text { Run 7 Position 2G } \\
\text { ID Number CZ246 }\end{array}$ & $0.25 \mathrm{~m}$ & Tube Wall Between 2J \& 2G & $116.0^{\circ} \mathrm{C}$ \\
\hline $\begin{array}{c}\text { Run 10 Position 2J } \\
\text { ID Number CZ346 }\end{array}$ & $0.38 \mathrm{~m}$ & Center Rod Cladding & $146.3^{\circ} \mathrm{C}$ \\
\cline { 2 - 4 } & $0.25 \mathrm{~m}$ & Tube Wall Between 2J \& 2G & $73.3^{\circ} \mathrm{C}$ \\
\hline $\begin{array}{c}\text { Run 11A Position 2J } \\
\text { ID Number CZ346 }\end{array}$ & $0.13 \mathrm{~m}$ & Center Rod Cladding & $92.1^{\circ} \mathrm{C}$ \\
\cline { 2 - 5 } & $0.25 \mathrm{~m}$ & Tube Wall Between 2J \& 2G & $86.7^{\circ} \mathrm{C}$ \\
\hline
\end{tabular}


The fuel tube corner with the highest temperature was selected to be used as the uniform basket wall temperature around the homogeneous assembly model. In the center of the REA 2023 design, there is a thermal shunt to the shell of the storage cask (a plate of copper) which lowers the centerline temperature below that of next diagonal corner. Therefore the basket (tube) temperature at the $0.25 \mathrm{~m}$ radial position was used instead of the temperature at the center $(0.0 \mathrm{~m}$ radial position).

The assembly heat generation rate for each of the test assemblies at the experiment start date $(01 / 13 / 85)$ along with a reduction rate in the assembly heat generation rate (in watts per day) is provided in the test report. ${ }^{[21]}$ Thus, the assembly heat output on the day of each test can be determined from the recorded date for the measurements (initial heat minus the number of days times the daily decay rate). Table 7.2-6 provides the date of each test considered here and the result of the assembly heat determination.

Table 7.2-6. REA 2023 Assembly Heat Outputs ${ }^{[21]}$

\begin{tabular}{||c|c|c|c||}
\hline Assembly / Experiment Date & $\begin{array}{c}\text { Heat at Date } \\
01 / 13 / 85\end{array}$ & Daily Decay Rate & $\begin{array}{c}\text { Heat at Date of } \\
\text { Experiment }\end{array}$ \\
\hline \hline $\begin{array}{c}\text { Position 2J - ID CZ346 } \\
\text { Run 6B 01/19/85 }\end{array}$ & 360.0 watts & 0.36 watts/day & 357.8 watts \\
\hline $\begin{array}{c}\text { Position 2G - ID CZ246 } \\
\text { Run 7 01/25/85 }\end{array}$ & 316.0 watts & 0.36 watts/day & 311.7 watts \\
\hline $\begin{array}{c}\text { Position 2J - ID CZ346 } \\
\text { Run 10 02/14/85 }\end{array}$ & 360.0 watts & 0.36 watts/day & 348.5 watts \\
\hline $\begin{array}{c}\text { Position 2J - ID CZ346 } \\
\text { Run 11A 02/05/85 }\end{array}$ & 360.0 watts & 0.36 watts/day & 351.7 watts \\
\hline
\end{tabular}

For each of the benchmark assemblies, the basket temperature (used as an edge boundary condition) and assembly heat load were applied to the homogeneous BWR SNF assembly model. To complete the benchmark, calculated peak cladding temperatures are compared to those measured in the REA 2023 storage cask test. Measured and calculated cladding temperatures as well as Wooton-Epstein predictions of cladding temperature are compared in Table 7.2-7. For each case, peak cladding temperatures predicted by the homogeneous SNF model, using the effective thermal conductivity method, are compared to post-test predictions performed by Pacific Northwest Laboratory using the HYDRA and COBRA-SFS codes as part of the REA 2023 storage cask testing (estimated from Appendix D and Appendix $E$ of the test report ${ }^{[21]}$ ). Additional calculations of estimated peak cladding temperature were also performed using the Wooton-Epstein ${ }^{[5]}$ correlation. The WootonEpstein correlation is used as described in Section 5 with the assembly and basket dimensions of Table 3.3-3. The fuel tube temperature of Table 7.2-5, assembly heats of Table 7.2-6, and a peaking factor of 1.20 were also used. 
Table 7.2-7. REA 2023 Temperature Benchmark Comparisons

\begin{tabular}{|c|c|c|}
\hline Assembly & Result Source & $\begin{array}{c}\text { Peak Cladding } \\
\text { Temperature }\end{array}$ \\
\hline \multirow{2}{*}{$\begin{array}{l}\text { Position 2J - ID CZ346 } \\
\text { Run 6B 01/19/85 }\end{array}$} & REA 2023 Measured & $173^{\circ} \mathrm{C}$ \\
\hline & Effective Conductivity Model & $174^{\circ} \mathrm{C}$ \\
\hline \multirow[t]{3}{*}{ Vertical / Vacuum } & COBRA-SFS ${ }^{[21]}$ & $167^{\circ} \mathrm{C}$ \\
\hline & HYDRA $^{[21]}$ & $179^{\circ} \mathrm{C}$ \\
\hline & Wooton-Epstein & $162^{\circ} \mathrm{C}$ \\
\hline \multirow{2}{*}{$\begin{array}{l}\text { Position 2G - ID CZ246 } \\
\quad \text { Run } 7 \text { 01/25/85 }\end{array}$} & REA 2023 Measured & $146^{\circ} \mathrm{C}$ \\
\hline & Effective Conductivity Model & $149^{\circ} \mathrm{C}$ \\
\hline \multirow[t]{3}{*}{ Vertical / Nitrogen } & COBRA-SFS ${ }^{[21]}$ & $133^{\circ} \mathrm{C}$ \\
\hline & $\mathrm{HYDRA}^{[21]}$ & $129^{\circ} \mathrm{C}$ \\
\hline & Wooton-Epstein & $144^{\circ} \mathrm{C}$ \\
\hline \multirow{2}{*}{$\begin{array}{l}\text { Position 2J - ID CZ346 } \\
\text { Run } 10 \text { 02/14/85 }\end{array}$} & REA 2023 Measured & $92^{\circ} \mathrm{C}$ \\
\hline & Effective Conductivity Model & $95^{\circ} \mathrm{C}$ \\
\hline \multirow[t]{3}{*}{ Horizontal / Helium } & COBRA-SFS ${ }^{[21]}$ & $96^{\circ} \mathrm{C}$ \\
\hline & HYDRA $^{[21]}$ & $113^{\circ} \mathrm{C}$ \\
\hline & Wooton-Epstein & $109^{\circ} \mathrm{C}$ \\
\hline \multirow{2}{*}{$\begin{array}{l}\text { Position 2J - ID CZ346 } \\
\text { Run 11A 2/05/85 }\end{array}$} & REA 2023 Measured & $106^{\circ} \mathrm{C}$ \\
\hline & Effective Conductivity Model & $108^{\circ} \mathrm{C}$ \\
\hline \multirow[t]{3}{*}{ Vertical / Helium } & COBRA-SFS ${ }^{[21]}$ & $118^{\circ} \mathrm{C}$ \\
\hline & HYDRA $^{[21]}$ & $117^{\circ} \mathrm{C}$ \\
\hline & Wooton-Epstein & $121^{\circ} \mathrm{C}$ \\
\hline
\end{tabular}

Table 7.2-7 demonstrates the best estimate peak cladding temperature predictions with the effective thermal conductivity method is reasonably good. The homogeneous SNF model slightly overpredicts the peak cladding temperatures for each of the experimental conditions by $1^{\circ} \mathrm{C}$ to $3^{\circ} \mathrm{C}$. The over-predicted peak cladding temperatures may be due to the method used to place thermocouples near the cladding in the cask test. The thermocouple was placed on a thin metal bracket which was then friction fitted into the BWR assembly such that the thermocouple was next to the center rod clad and the other end of the bracket was on the outer edge of the BWR assembly. Thus, a small 
conduction path from the center rod of the assembly to the outer edge of assembly was created at this location by the metal bracket. This may influence the local temperature and may cause the cladding temperature measurements to be slightly low. Thus, the effective thermal conductivity should be considered a best estimate method to predict peak cladding temperatures, and these few benchmarks indicate that it is reasonably accurate.

The benchmark comparisons were performed for both vertical and horizontal orientations. The effective thermal conductivity method over-predicted peak cladding temperatures for the horizontal orientation by no more than $3.2^{\circ} \mathrm{C} .^{[49]}$ Since the effective thermal conductivity was developed with the assumption that the BWR SNF assembly does not contact the basket wall, it should be expected that peak cladding temperatures will be consistently high for horizontal orientations. However, the horizontal benchmark indicates that the effective thermal conductivity model performs reasonably well.

It should be noted that if the effective thermal conductivity method were used in a full model of the REA 2023 storage cask, a range of boundary temperatures would result around each assembly, and predicted peak temperatures could be slightly different than those reported in this evaluation. (The homogeneous SNF model assumes a uniform basket wall temperature.) Also, the assembly positions selected for the benchmarks are in the center of the storage cask where radial basket temperature gradients are flattest. A full scale benchmark model using the effective thermal conductivity method for BWR assemblies has not been completed at this time; however, a half cask benchmark for a PWR cask is provided in Section 7.3.

The COBRA-SFS and the HYDRA models used full three-dimensional representations of the storage cask and the individual BWR assemblies. The peak cladding temperatures predicted with these codes was typically within $12 \%$ of the measured data. ${ }^{[2]]}$ The initial indications provided by the results in Table 7.2-7 are that the effective thermal conductivity method may provide peak cladding predictions with equivalent or even better accuracy than realized with the COBRA-SFS and the HYDRA models.

The Wooton-Epstein correlation consistently over-predicted the peak cladding temperatures for the helium fill gas benchmarks. This should be expected since Wooton-Epstein was developed for air which has a significantly lower thermal conductivity than helium. However, for the vacuum and nitrogen cases the Wooton-Epstein correlation is not necessarily conservative. This is due to the fact that the Wooton-Epstein correlation was developed from experimental data based upon air with convection and radiation heat transfer in a $17 \times 18$ rod array. The storage cask analyses for the vacuum and nitrogen cases do not include the convection heat transfer mode, and the vacuum case will not have conduction or convection heat transfer. Thus, it is expected that significant deviations are observed for the comparisons to the Wooton-Epstein correlation. And, as seen in previous sections, the high conductivity of helium more than compensates for the air convection term of the Wooton-Epstein correlation. 


\subsection{Half Cask Benchmark of Effective Thermal Conductivity}

To demonstrate and benchmark the use of the effective thermal conductivity method, a half cask model of the TN-24P storage cask ${ }^{[23]}$ was developed and evaluated. As described in Section 7.2.2, several performance tests were conducted at INEL with the TN-24P in horizontal and vertical orientations with fill environments of helium, nitrogen, and vacuum. For each test, temperatures were measured with an array of thermocouples and compared to pre-test and post-test predictions with the COBRA-SFS heat transfer computer codes.

The test most applicable to repository disposal considered a horizontal cask with helium fill gas. Using the ANSYS code, a 2-D model of one-half of the TN-24P storage cask was developed to match the conditions of this test with measured cask surface temperatures applied as external boundary conditions and reported assembly heat loads applied to the (assumed) homogeneous assembly areas. Each assembly area in the model was represented by a $14 \times 14$ element mesh with smeared properties, including the effective thermal conductivities for use in finite element analysis (see Section 6). To match test conditions as closely as possible (and to show that the effective thermal conductivity method is a good "best estimate" tool), the effective thermal conductivities for a 15x15 PWR assembly in helium fill gas ${ }^{[48]}$ were assumed instead of the more conservative values for the 17x17 array (as recommended in Table 6.2-1).

Since the ANSYS model is a 2-D slice of the cask, we are interested in temperatures near the axial mid-length of the cask where temperatures are highest (an axial location of about $2.3 \mathrm{~m}$ ). The basket and assembly thermocouples at the axial mid-length and the positions of assemblies considered in the model (positions D1 through D6 and C1 through C6) are displayed graphically in Figure 7.2-1 (in Section 7.2.2). Not shown in Figure 7.2-1 are the thermocouples around the TN-24P surface. Temperatures from the horizontal helium test for the surface thermocouples near the axial midlength, used as boundary conditions here, are listed below in Table 7.3-1. These temperatures were distributed around the outer surface of the ANSYS model.

Table 7.3-1. TN-24P Surface Thermocouple Temperatures at Axial Mid-Length ${ }^{[23]}$

\begin{tabular}{||cc|c|}
\hline Position & Thermocouple & $\begin{array}{c}\text { Temperature During } \\
\text { Horizontal Helium Test }\end{array}$ \\
\hline \hline Top Surface $\left(0^{\circ}\right)$ & $\mathrm{TC} 64$ & $75.9^{\circ} \mathrm{C}$ \\
\hline Side Surface $\left(270^{\circ}\right)$ & $\mathrm{TC} 78$ & $75.2^{\circ} \mathrm{C}$ \\
\hline Bottom Surface $\left(180^{\circ}\right)$ & $\mathrm{TC} 74$ & $83.1^{\circ} \mathrm{C}$ \\
\hline
\end{tabular}


The assembly heat outputs for each of the test assemblies, reported for the beginning and ending dates, are provided in Table 3-3 of the TN-24P report. ${ }^{[23]}$ The two dates correspond to the first experiment performed (vertical cask with helium fill gas) and the last experiment performed (horizontal cask with vacuum). The individual assembly heat loads for the other experiments can be roughly estimated by linear interpolation using the dates reported for each test. Table 7.3-2 provides the results of the heat determination. The heat loads for the TN-24P cask in a horizontal orientation with a fill gas of helium were considered in this benchmark.

Table 7.3-2. TN-24P Assembly Heat Outputs ${ }^{[23]}$

\begin{tabular}{||c|c|c|c||}
\hline Assembly & $\begin{array}{c}\text { Vertical } \\
\text { Helium }\end{array}$ & $\begin{array}{c}\text { Horizontal } \\
\text { Helium }\end{array}$ & $\begin{array}{c}\text { Horizontal } \\
\text { Vacuum }\end{array}$ \\
\cline { 2 - 4 } & $\begin{array}{c}01 / 14 / 86 \\
\text { Start }\end{array}$ & $01 / 27 / 86$ & $\begin{array}{c}02 / 06 / 86 \\
\text { End }\end{array}$ \\
\hline \hline $\begin{array}{c}\text { Position D1 } \\
\text { ID Number V18 }\end{array}$ & 919.2 watts & 911.2 watts & 905.0 watts \\
\hline $\begin{array}{c}\text { Position D2 } \\
\text { ID Number W44 }\end{array}$ & 852.0 watts & 844.7 watts & 839.0 watts \\
\hline $\begin{array}{c}\text { Position D3 } \\
\text { ID Number W46 }\end{array}$ & 852.0 watts & 844.7 watts & 839.0 watts \\
\hline $\begin{array}{c}\text { Position D4 } \\
\text { ID Number W06 }\end{array}$ & 859.0 watts & 851.7 watts & 846.0 watts \\
\hline $\begin{array}{c}\text { Position D5 } \\
\text { ID Number V16 }\end{array}$ & 870.0 watts & 862.4 watts & 856.5 watts \\
\hline $\begin{array}{c}\text { Position D6 } \\
\text { ID Number W02 }\end{array}$ & 845.5 watts & 838.0 watts & 832.3 watts \\
\hline $\begin{array}{c}\text { Position C1 } \\
\text { ID Number V10 }\end{array}$ & 870.0 watts & 862.4 watts & 856.5 watts \\
\hline $\begin{array}{c}\text { Position C2 } \\
\text { ID Number W38 }\end{array}$ & 852.0 watts & 844.7 watts & 839.0 watts \\
\hline $\begin{array}{c}\text { Position C3 } \\
\text { D Number W45 }\end{array}$ & 845.5 watts & 838.0 watts & 832.3 watts \\
\hline $\begin{array}{c}\text { Position C4 } \\
\text { ID Number W27 }\end{array}$ & 859.0 watts & 851.7 watts & 846.0 watts \\
\hline $\begin{array}{c}\text { Position C5 } \\
\text { ID Number W28 }\end{array}$ & 852.0 watts & 844.7 watts & 839.0 watts \\
\hline $\begin{array}{c}\text { Position C6 } \\
\text { ID Number W23 }\end{array}$ & 845.5 watts & 838.0 watts & 832.3 watts \\
\hline
\end{tabular}


The ANSYS model of the TN-24P cask was evaluated for the conditions of the horizontal helium test. Figure 7.3-1 displays the resulting temperature contours (in degrees $\mathrm{C}$ ) for the benchmark case. To complete the benchmark, calculated temperatures for positions throughout the basket and positions in the homogeneous assembly (where guide tubes would be) are compared to those measured in the TN-24P test. The measured and calculated temperatures as well as predictions of peak cladding temperatures are presented in Table 7.3-3. Comparisons for all of the thermocouples at the axial mid-length of the cask (left side) are provided (see Figure 7.2-1 for thermocouple and assembly positions). Peak cladding temperatures for assembly positions D1 and D5 are also compared to pre-test predictions performed by PNL using the COBRA-SFS code ${ }^{[23]}$ and alternate calculations (see Section 7.2.2) using the Wooton-Epstein ${ }^{[5]}$ correlation.

Table 7.3-3. TN-24P Half Cask Temperature Benchmark Comparisons

\begin{tabular}{|c|c|c|c|}
\hline Position & Thermocouple & $\begin{array}{c}\mathrm{TN}-24 \mathrm{P} \\
\text { Experiment }\end{array}$ & $\begin{array}{l}\text { ANSYS Half } \\
\text { Cask Model }\end{array}$ \\
\hline Corner Guide Lance & $\mathrm{TC} 3$ & $152^{\circ} \mathrm{C}$ & $139^{\circ} \mathrm{C}$ \\
\hline Guide Tube in D1 & TC9 & $206^{\circ} \mathrm{C}$ & $208^{\circ} \mathrm{C}$ \\
\hline Guide Tube in D4 & TC15 & $199^{\circ} \mathrm{C}$ & $193^{\circ} \mathrm{C}$ \\
\hline Guide Tube in D5 & $\mathrm{TC} 21$ & $173^{\circ} \mathrm{C}$ & $156^{\circ} \mathrm{C}$ \\
\hline Guide Tube in D6 & $\mathrm{TC} 33$ & $161^{\circ} \mathrm{C}$ & $141^{\circ} \mathrm{C}$ \\
\hline Guide Tube in $\mathrm{C} 6$ & TC39 & $148^{\circ} \mathrm{C}$ & $144^{\circ} \mathrm{C}$ \\
\hline Inside Cask Surface & TC98 & $93^{\circ} \mathrm{C}$ & $91^{\circ} \mathrm{C}$ \\
\hline Inside Cask Surface & TC 99 & $93^{\circ} \mathrm{C}$ & $91^{\circ} \mathrm{C}$ \\
\hline Basket Near D5 & TC104 & $123^{\circ} \mathrm{C}$ & $126^{\circ} \mathrm{C}$ \\
\hline Basket Near D5 & $\mathrm{TC} 105$ & $127^{\circ} \mathrm{C}$ & $126^{\circ} \mathrm{C}$ \\
\hline Basket Near D3 & TC106 & $122^{\circ} \mathrm{C}$ & $121^{\circ} \mathrm{C}$ \\
\hline Center Basket & TC107 & $193^{\circ} \mathrm{C}$ & $193^{\circ} \mathrm{C}$ \\
\hline Basket Near C3 & TC108 & $148^{\circ} \mathrm{C}$ & $108^{\circ} \mathrm{C}$ \\
\hline \multirow[t]{2}{*}{ Peak Cladding in D1 } & COBRA-SFS & $222^{\circ} \mathrm{C}$ & \multirow{2}{*}{$214^{\circ} \mathrm{C}$} \\
\hline & Wooton-Epstein & $248^{\circ} \mathrm{C}$ & \\
\hline Peak Cladding in D5 & Wooton-Epstein & $189^{\circ} \mathrm{C}$ & $178^{\circ} \mathrm{C}$ \\
\hline
\end{tabular}


It should be noted that this benchmark evaluation is not an attempt to perfectly match every feature of the TN-24P storage cask performance test; it is a demonstration of a method for predicting peak cladding temperatures within an SNF container. A detailed analysis of the TN-24P storage cask would require complete detailed design and assembly descriptions with specific dimensions which is not necessary here since it has already been performed by PNL using the COBRA-SFS code. It would be sufficient to compare temperature drops across the assemblies to verify the effective thermal conductivity method.

The first points to compare are the temperatures on the inside wall of the cask (TC98 and TC99). A $2^{\circ} \mathrm{C}$ temperature difference indicates that the half cask model is estimating the temperature drop across the cask wall and radiation shielding material with reasonable accuracy. Next, the temperatures measured at various places throughout the aluminum plate basket are compared (TC104, TC105, TC106, TC107, and TC108). Thermocouples TC104 and TC105 were placed at the same location on the basket wall and indicate the reliability of the thermocouples (they differed by $4^{\circ} \mathrm{C}$ ). The half cask model both over-predicted (by $3^{\circ} \mathrm{C}$ ) and under-predicted (by $1^{\circ} \mathrm{C}$ ) this position. Thermocouple TC106 was matched within $1^{\circ} \mathrm{C}$; and TC107, at the center of the basket near assembly position D1, was matched within $0.2{ }^{\circ} \mathrm{C}{ }^{[48]}$ Thermocouple TC3 was placed in a lance tube near the basket plate supports; since neither of these structures were modeled here, it is not surprising that a $13^{\circ} \mathrm{C}$ difference was observed. Thermocouple TC108, for which the largest difference $\left(40^{\circ} \mathrm{C}\right)$ was found, may be an anomalous reading or it may not have been compared to the correct position in the SNF basket here.

The last values to be compared are the thermocouples placed within assembly guide tubes in several of the assemblies (TC9, TC15, TC21, TC33, and TC39). Generally, the effective thermal conductivity method under-predicted assembly temperatures in locations where basket temperature gradients were high, and more accurately predicted temperatures where gradients were low (such as in the center of the basket). TC9, the guide tube in assembly position D1, was over-predicted in the homogeneous assembly by $2^{\circ} \mathrm{C}$. This correlates well, given the match in the nearby basket temperature, with the trending for assembly D1 observed in the single assembly benchmark (Table 7.2-4). In the single assembly analysis, the SNF model over-predicted the guide tube temperature by about $10^{\circ} \mathrm{C}$ due to the assumption of a uniform basket wall temperature around the assembly. In this case, with the basket completely modeled, a better match was predicted. Peak cladding temperatures in assembly D1 were predicted to be about $6^{\circ} \mathrm{C}$ higher than the predicted guide tube temperature. This matches the temperature drop of $6^{\circ} \mathrm{C}$ (peak to guide tube) estimated in the COBRA-SFS calculation (see Table 7.2-4).

Thermocouples TC33 and TC39 are located at opposite sides of the TN-24P cask (see Figure 7.2-1). As discussed in the TN-24P report, ${ }^{[23]}$ the SNF basket and assemblies settled toward the bottom of the cask when oriented horizontally. This resulted in a better heat transfer path through the bottom portion of the cask and higher temperatures toward the top. Since the basket and assembly settling was not modeled here, this is a likely reason for a $21^{\circ} \mathrm{C}$ difference for TC33 (at the top) and only a $4{ }^{\circ} \mathrm{C}$ difference for TC39 (at the bottom). 
The guide tube temperature within assembly position D5 (TC21) was under-predicted by the effective thermal conductivity method by $17^{\circ} \mathrm{C}$. However, the peak cladding temperature in assembly position $\mathrm{D} 5$ was found to be $18^{\circ} \mathrm{C}$ higher than the single assembly prediction in Table 7.24. In the single assembly analysis, it was estimated that the discrete SNF model under-predicted the guide tube temperature due to the assumption of a uniform basket wall temperature (based on the outside edge) around the assembly. In this case, with the basket completely modeled, peak temperatures were significantly higher. Finally, the guide tube in assembly position D4 (TC15) was under-predicted by $6^{\circ} \mathrm{C}$.

Table 7.3-3 demonstrates, again, a best estimate prediction with the effective thermal conductivity method. As expected, the Wooton-Epstein solutions (which really only apply to assemblies in air) predicted temperatures significantly higher for the helium fill gas. While no thermocouple data is available for peak cladding temperatures for this test, the effective thermal conductivity method predicted cladding temperatures consistent with those predicted by the COBRA-SFS analysis. This benchmark test indicates that the effective thermal conductivity method can accurately predict a "best estimate" of temperatures within a PWR assembly for at least the center of an SNF canister where basket thermal gradients are low and peak SNF temperature typically occur. 


\section{Conclusions and Recommendations}

As part of the engineered barrier system for the containment of radionuclides, the waste package must be shown to comply with all regulations and requirements that govern the conditions of the emplaced spent nuclear fuel and the near-field rock at the repository horizon. Temperatures in the WP and near-field host rock are key to radionuclide containment, as they directly affect oxidation rates of the metal barriers and the ability of the rock to impede particle movement.

A key thermal goal for SNF waste package design is the $350^{\circ} \mathrm{C}$ cladding temperature limit. To determine SNF cladding temperatures in each of the SNF waste package design concepts, a four level approach has been assumed. A 3-D transient finite element model of the WP emplacement drift and surrounding rock provides the WP surface temperature history for use as a boundary condition in a detailed WP design model. At times greater than 1000 years after emplacement, these temperature predictions are augmented with the results of a 2-D axisymmetric disk model of the entire repository to correct for position within the repository and repository edge effect cooling. WP surface temperatures provide the boundary condition for a more detailed thermal analysis of WP internal structures. Finally, resulting SNF basket wall temperature predictions from the WP model provide the boundary for an estimation of peak SNF cladding temperatures. Cladding temperatures are predicted in the WP model using a homogeneous SNF assembly with an effective thermal conductivity (defined in this report).

The objective of this report is to describe the development of effective thermal conductivities for PWR and BWR SNF assemblies as a methodology for performing future waste package thermal analyses. As identified in Section 1.2, the input data and assumptions used in this report will require further confirmation as the waste package design proceeds. Finite element models of various SNF assembly types with fill environments of helium, vacuum, nitrogen, and argon have been developed and then used as the basis for the determination of effective thermal conductivities of assemblies with smeared (homogeneous) properties. Effective thermal conductivities are defined here using detailed models of intact SNF assemblies evaluated over a range of temperatures and heat loads. Effective thermal conductivities are an alternate methodology to the Wooton-Epstein correlation ${ }^{[5]}$ for the prediction of SNF cladding temperatures. Cladding temperatures determined using derived effective thermal conductivities are compared to temperatures using other cladding temperature prediction methods; and the finite element models and effective thermal conductivities are benchmarked against SNF storage cask tests. The SNF assembly thermal models also provide the trending and thermal behavior of SNF assemblies with a dry fill gas (and filler material, see Reference 47) including the effects of channels, water rods, oxidation thickness, and basket wall gradients.

Over-prediction of SNF cladding temperatures due to excessive conservatism can constrain waste package design and limit the capacity of potential waste package design concepts. The analyses performed here indicate that the discrete SNF models are more accurate and realistic than other approaches for predicting SNF cladding temperatures. Further, the effective thermal conductivities, calculated using SNF model results, were found to be primarily a function of temperature, generally 
not a function of assembly heat load, and suitable for use in predicting best estimate temperatures of PWR and BWR SNF assemblies in fill environments of helium, vacuum, nitrogen, and argon (for at least the center of an SNF container where basket thermal gradients are low).

The effective thermal conductivities, both the basket wall temperature based values and the median temperature based values for use in finite element analyses, presented in Section 6, can be applied to SNF containers in a vertical or horizontal orientation. However, in a vertical orientation the effective thermal conductivity as developed in this evaluation does not account for natural convection heat transfer of the fill gas and may over-predict peak cladding temperatures. This can be significant for buoyant fill gases such as air, nitrogen, or argon. Also, in a horizontal orientation the effective thermal conductivity does not account for any contact between the SNF assembly and the basket wall which would lower temperatures compared to the effective thermal conductivity predictions. However, the effect of neglecting convection and contact with the assembly is to introduce a small conservative bias into the effective thermal conductivity method which is acceptable from a design point of view.

The discrete SNF assembly model results were compared to Wooton-Epstein ${ }^{[5]}$ correlation temperature predictions. For each helium fill gas case, the temperature drop across the assembly was roughly twice that predicted by the ANSYS SNF models. For fill environments of vacuum, nitrogen, and argon, the Wooton-Epstein correlation was seen to be conservative at higher basket wall temperatures, but somewhat nonconservative at lower temperatures (where SNF cladding temperatures would not be near design limits). The Wooton-Epstein results are not surprising, however, as the correlation was developed for PWR-sized assemblies in air.

Back check tests of the effective thermal conductivities for FEA were performed. The results showed cladding temperatures within $1.5^{\circ} \mathrm{C}$ of those estimated with the PWR and BWR discrete models (and less than $0.2^{\circ} \mathrm{C}$ in the heat load and temperature range of interest for disposal). The PWR and BWR effective thermal conductivities (for FEA) were also compared to numerical and experimental studies performed for the TN-24P ${ }^{[23]}$ and REA $2023^{[20,21]}$ storage casks. For the single assembly comparisons to the TN-24P tests, the discrete PWR SNF model and effective thermal conductivities slightly over-predicted center assembly guide tube temperatures compared to thermocouple data reported. While no thermocouple data was available for peak cladding temperatures in that test, the discrete PWR SNF model predicted peak cladding temperatures nearly identical to those predicted by the COBRA-SFS numerical analysis conducted as part of the TN-24P test. For the half cask benchmark of the TN-24P, the inclusion of basket wall gradients around the homogeneous assemblies (with effective thermal conductivities) resulted in center assembly and basket temperatures that closely matched the experimental data. However, for locations where basket gradients were high (near the cask perimeter) the effective thermal conductivity method was seen to under-predict assembly temperatures. Finally, for the single assembly comparisons to the REA 2023 tests, the BWR effective thermal conductivities (for FEA) slightly over-predicted the cladding temperature of the BWR assembly center rod compared to thermocouple data reported. Also, the effective thermal conductivity method predicted comparable peak cladding temperatures to those predicted by the HYDRA and COBRA-SFS numerical analyses conducted as part of the REA 2023 tests. 
For intact PWR and BWR assemblies, the conductivities derived from the discrete SNF models should provide a best estimate of SNF cladding temperatures. Effective thermal conductivities derived from the discrete PWR SNF models compare quite well with effective thermal conductivities developed by General Atomics for the GA-4 cask ${ }^{[33]}$ which were found to be just slightly more conservative. BWR effective thermal conductivities reported for the GA-9 cask, ${ }^{[34]}$ however, were found to be significantly nonconservative compared to the discrete SNF model results and the Wooton-Epstein correlation. Care should be taken, however, not to extrapolate the effective thermal conductivity results to alternate assembly designs (such as consolidated assemblies or assembly sizes not bounded here) or alternate fill gases for which calculations have not been completed at this time.

Bounding effective thermal conductivity recommendations for PWR SNF and BWR SNF (with and without channels) were made in Section 6. Table 8.0-1 summarizes the recommended bounding PWR effective thermal conductivity values to be used in conjunction with Equation 6.1-5 for analyses to predict the peak cladding temperature (based on a known basket wall temperature) without modeling the SNF assembly explicitly. Table 8.0-2 summarizes the recommended bounding PWR effective thermal conductivity values to be used with finite element (or finite difference) methods which explicitly model the SNF assembly as a homogeneous heat source.

Table 8.0-1. Average Effective Conductivities for PWR SNF (Basket Wall Based)

\begin{tabular}{||c||c|c|c|c||}
\hline $\begin{array}{c}\text { Basket Wall } \\
\text { Temperature }\end{array}$ & $\begin{array}{c}\text { Average } \mathrm{k}_{\mathrm{e}} \\
(\mathrm{W} / \mathrm{m} \cdot \mathrm{K}) \\
\text { in Helium }\end{array}$ & $\begin{array}{c}\text { Average } \mathrm{k}_{\mathrm{e}} \\
(\mathrm{W} / \mathrm{m} \cdot \mathrm{K}) \\
\text { in Vacuum }\end{array}$ & $\begin{array}{c}\text { Average } \mathrm{k}_{\mathrm{e}} \\
(\mathrm{W} / \mathrm{m} \cdot \mathrm{K}) \\
\text { in Nitrogen }\end{array}$ & $\begin{array}{c}\text { Average } \mathrm{k}_{\mathrm{e}} \\
(\mathrm{W} / \mathrm{m} \cdot \mathrm{K}) \\
\text { in Argon }\end{array}$ \\
\hline \hline $25^{\circ} \mathrm{C}$ & 0.412 & 0.136 & 0.185 & 0.170 \\
\hline $50^{\circ} \mathrm{C}$ & 0.451 & 0.157 & 0.210 & 0.195 \\
\hline $100^{\circ} \mathrm{C}$ & 0.540 & 0.209 & 0.272 & 0.253 \\
\hline $150^{\circ} \mathrm{C}$ & 0.643 & 0.277 & 0.347 & 0.326 \\
\hline $200^{\circ} \mathrm{C}$ & 0.762 & 0.363 & 0.440 & 0.417 \\
\hline $250^{\circ} \mathrm{C}$ & 0.898 & 0.469 & 0.551 & 0.525 \\
\hline $300^{\circ} \mathrm{C}$ & 1.053 & 0.596 & 0.682 & 0.654 \\
\hline $350^{\circ} \mathrm{C}$ & 1.224 & 0.743 & 0.832 & 0.804 \\
\hline $400^{\circ} \mathrm{C}$ & 1.414 & 0.914 & 1.005 & 0.976 \\
\hline
\end{tabular}


Spent Nuclear Fuel Effective Thermal Conductivity Report

Table 8.0-2. Effective Conductivities for PWR SNF (for FEA)

\begin{tabular}{|c|c|c|c|c|}
\hline $\begin{array}{c}\text { Assembly } \\
\text { Median } \\
\text { Temperature }\end{array}$ & $\begin{array}{l}\mathrm{K}_{\mathrm{e}} \text { for FEA } \\
\text { (W/m } \mathrm{W} \text { ) } \\
\text { in Helium }\end{array}$ & $\begin{array}{l}\mathrm{K}_{\mathrm{e}} \text { for FEA } \\
\text { (W/m.K) } \\
\text { in Vacuum }\end{array}$ & $\begin{array}{c}\mathrm{K}_{\mathrm{e}} \text { for FEA } \\
\text { (W/m } \mathrm{K} \text { ) } \\
\text { in Nitrogen }\end{array}$ & $\begin{array}{c}\mathrm{K}_{\mathrm{e}} \text { for FEA } \\
(\mathrm{W} / \mathrm{m} \cdot \mathrm{K}) \\
\text { in Argon }\end{array}$ \\
\hline $25^{\circ} \mathrm{C}$ & 0.384 & 0.086 & 0.144 & 0.127 \\
\hline $50^{\circ} \mathrm{C}$ & 0.423 & 0.107 & 0.170 & 0.152 \\
\hline $100^{\circ} \mathrm{C}$ & 0.512 & 0.163 & 0.232 & 0.212 \\
\hline $150^{\circ} \mathrm{C}$ & 0.616 & 0.234 & 0.310 & 0.288 \\
\hline $200^{\circ} \mathrm{C}$ & 0.736 & 0.324 & 0.406 & 0.380 \\
\hline $250^{\circ} \mathrm{C}$ & 0.874 & 0.432 & 0.519 & 0.491 \\
\hline $300^{\circ} \mathrm{C}$ & 1.028 & 0.561 & 0.651 & 0.622 \\
\hline $350^{\circ} \mathrm{C}$ & 1.201 & 0.711 & 0.804 & 0.774 \\
\hline $400^{\circ} \mathrm{C}$ & 1.392 & 0.884 & 0.978 & 0.948 \\
\hline
\end{tabular}

For BWR assemblies, sufficient difference was observed between assemblies with the channels and assemblies with the channels removed, that separate effective thermal conductivities are provided for each. Tables 8.0-3 and 8.0-4 (with and without a channel) summarize the recommended bounding BWR effective thermal conductivity values to be used in conjunction with Equation 6.1-5 for analyses which predict peak cladding temperatures based on a known basket temperature without modeling the SNF assembly explicitly.

Table 8.0-3. Average Effective Conductivities for BWR SNF, with Channel

\begin{tabular}{||c||c|c|c|c||}
\hline \begin{tabular}{c}
\hline Basket Wall \\
Temperature
\end{tabular} & $\begin{array}{c}\text { Average } \mathrm{k}_{\mathrm{e}} \\
(\mathrm{W} / \mathrm{m} \cdot \mathrm{K}) \\
\text { in Helium }\end{array}$ & $\begin{array}{c}\text { Average } \mathrm{k}_{\mathrm{e}} \\
(\mathrm{W} / \mathrm{m} \cdot \mathrm{K}) \\
\text { in Vacuum }\end{array}$ & $\begin{array}{c}\text { Average } \mathrm{k}_{\mathrm{e}} \\
(\mathrm{W} / \mathrm{m} \cdot \mathrm{K}) \\
\text { in Nitrogen }\end{array}$ & $\begin{array}{c}\text { Average } \mathrm{k}_{\mathrm{e}} \\
\text { (W/m/K) } \\
\text { in Argon }\end{array}$ \\
\hline \hline $25^{\circ} \mathrm{C}$ & 0.303 & 0.094 & 0.128 & 0.118 \\
\hline $50^{\circ} \mathrm{C}$ & 0.332 & 0.110 & 0.147 & 0.136 \\
\hline $100^{\circ} \mathrm{C}$ & 0.396 & 0.150 & 0.192 & 0.180 \\
\hline $150^{\circ} \mathrm{C}$ & 0.470 & 0.202 & 0.250 & 0.235 \\
\hline $200^{\circ} \mathrm{C}$ & 0.556 & 0.278 & 0.320 & 0.304 \\
\hline $250^{\circ} \mathrm{C}$ & 0.655 & 0.348 & 0.405 & 0.386 \\
\hline $300^{\circ} \mathrm{C}$ & 0.768 & 0.446 & 0.505 & 0.485 \\
\hline $350^{\circ} \mathrm{C}$ & 0.892 & 0.560 & 0.621 & 0.602 \\
\hline $400^{\circ} \mathrm{C}$ & 1.032 & 0.692 & 0.755 & 0.735 \\
\hline
\end{tabular}


Table 8.0-4. Average Effective Conductivities for BWR SNF, No Channel

\begin{tabular}{||c||c|c|c|c||}
\hline $\begin{array}{c}\text { Basket Wall } \\
\text { Temperature }\end{array}$ & $\begin{array}{c}\text { Average } \mathrm{k}_{\mathrm{e}} \\
(\mathrm{W} / \mathrm{m} \cdot \mathrm{K}) \\
\text { in Helium }\end{array}$ & $\begin{array}{c}\text { Average } \mathrm{k}_{\mathrm{c}} \\
(\mathrm{W} / \mathrm{m} \cdot \mathrm{K}) \\
\text { in Vacuum }\end{array}$ & $\begin{array}{c}\text { Average } \mathrm{k}_{\mathrm{e}} \\
(\mathrm{W} / \mathrm{m} \cdot \mathrm{K}) \\
\text { in Nitrogen }\end{array}$ & $\begin{array}{c}\text { Average } \mathrm{k}_{\mathrm{c}} \\
(\mathrm{W} / \mathrm{m} \cdot \mathrm{K}) \\
\text { in Argon }\end{array}$ \\
\hline \hline $25^{\circ} \mathrm{C}$ & 0.311 & 0.110 & 0.144 & 0.134 \\
\hline $50^{\circ} \mathrm{C}$ & 0.344 & 0.130 & 0.166 & 0.156 \\
\hline $100^{\circ} \mathrm{C}$ & 0.419 & 0.180 & 0.223 & 0.210 \\
\hline $150^{\circ} \mathrm{C}$ & 0.507 & 0.246 & 0.293 & 0.279 \\
\hline $200^{\circ} \mathrm{C}$ & 0.611 & 0.327 & 0.380 & 0.364 \\
\hline $250^{\circ} \mathrm{C}$ & 0.730 & 0.429 & 0.486 & 0.467 \\
\hline $300^{\circ} \mathrm{C}$ & 0.867 & 0.550 & 0.611 & 0.591 \\
\hline $350^{\circ} \mathrm{C}$ & 1.021 & 0.693 & 0.756 & 0.736 \\
\hline $400^{\circ} \mathrm{C}$ & 1.192 & 0.858 & 0.922 & 0.902 \\
\hline
\end{tabular}

Tables 8.0-5 and 8.0-6 (with and without a channel) summarize the recommended bounding BWR effective thermal conductivity values to be used with finite element (or finite difference) methods which explicitly model the SNF assembly as a homogeneous heat source.

Table 8.0-5. Effective Conductivities for BWR SNF (for FEA), with Channel

\begin{tabular}{|c|c|c|c|c|}
\hline $\begin{array}{c}\text { Assembly } \\
\text { Median } \\
\text { Temperature } \\
\end{array}$ & $\begin{array}{l}\mathrm{K}_{\mathrm{e}} \text { for FEA } \\
\text { (W/m.K) } \\
\text { in Helium }\end{array}$ & $\begin{array}{c}\mathrm{K}_{\mathrm{e}} \text { for FEA } \\
\text { (W/m } \cdot \mathrm{K} \text { ) } \\
\text { in Vacuum }\end{array}$ & $\begin{array}{l}\mathrm{K}_{\mathrm{e}} \text { for FEA } \\
\text { (W/m.K) } \\
\text { in Nitrogen }\end{array}$ & $\begin{array}{c}\mathrm{K}_{\mathrm{e}} \text { for FEA } \\
\text { (W/m } \mathrm{W} \text { ) } \\
\text { in Argon }\end{array}$ \\
\hline $25^{\circ} \mathrm{C}$ & 0.290 & 0.067 & 0.105 & 0.094 \\
\hline $50^{\circ} \mathrm{C}$ & 0.317 & 0.081 & 0.122 & 0.110 \\
\hline $100^{\circ} \mathrm{C}$ & 0.379 & 0.121 & 0.167 & 0.153 \\
\hline $150^{\circ} \mathrm{C}$ & 0.455 & 0.175 & 0.226 & 0.210 \\
\hline $200^{\circ} \mathrm{C}$ & 0.542 & 0.244 & 0.299 & 0.282 \\
\hline $250^{\circ} \mathrm{C}$ & 0.643 & 0.328 & 0.387 & 0.369 \\
\hline $300^{\circ} \mathrm{C}$ & 0.755 & 0.427 & 0.489 & 0.470 \\
\hline $350^{\circ} \mathrm{C}$ & 0.881 & 0.542 & 0.605 & 0.585 \\
\hline $400^{\circ} \mathrm{C}$ & 1.019 & 0.673 & 0.736 & 0.715 \\
\hline
\end{tabular}


Table 8.0-6. Effective Conductivities for BWR SNF (for FEA), No Channel

\begin{tabular}{||c||c|c|c|c||}
\hline $\begin{array}{c}\text { Assembly } \\
\text { Median } \\
\text { Temperature }\end{array}$ & $\begin{array}{c}\mathrm{K}_{\mathrm{e}} \text { for FEA } \\
\text { (W/m } \mathrm{K} \text { ) } \\
\text { in Helium }\end{array}$ & $\begin{array}{c}\mathrm{K}_{\mathrm{e}} \text { for FEA } \\
\text { (W/m/K) } \\
\text { in Vacuum }\end{array}$ & $\begin{array}{c}\mathrm{K}_{\mathrm{e}} \text { for FEA } \\
\text { (W/m·K) } \\
\text { in Nitrogen }\end{array}$ & $\begin{array}{c}\mathrm{K}_{\mathrm{e}} \text { for FEA } \\
\text { (W/m/K) } \\
\text { in Argon }\end{array}$ \\
\hline \hline $25^{\circ} \mathrm{C}$ & 0.296 & 0.082 & 0.120 & 0.109 \\
\hline $50^{\circ} \mathrm{C}$ & 0.327 & 0.100 & 0.141 & 0.129 \\
\hline $100^{\circ} \mathrm{C}$ & 0.400 & 0.149 & 0.195 & 0.181 \\
\hline $150^{\circ} \mathrm{C}$ & 0.489 & 0.217 & 0.268 & 0.252 \\
\hline $200^{\circ} \mathrm{C}$ & 0.595 & 0.303 & 0.359 & 0.342 \\
\hline $250^{\circ} \mathrm{C}$ & 0.717 & 0.408 & 0.468 & 0.449 \\
\hline $300^{\circ} \mathrm{C}$ & 0.855 & 0.533 & 0.595 & 0.575 \\
\hline $350^{\circ} \mathrm{C}$ & 1.009 & 0.676 & 0.740 & 0.719 \\
\hline $400^{\circ} \mathrm{C}$ & 1.178 & 0.838 & 0.903 & 0.882 \\
\hline
\end{tabular}

BWR assemblies without channels can be evaluated using the effective thermal conductivities for assemblies with channels, however, this approach may be overly conservative for some evaluations. Therefore, the conductivities for BWR assemblies both with and without channels are reported here. However, if a "generic" BWR assembly is the target of a thermal evaluation, it is recommended that the effective thermal conductivities for channeled BWR assemblies be used to be conservative. Also, while the different BWR assembly designs resulted in minor differences that can be bounded by one assembly array, results for different fill environments varied significantly. Therefore, the appropriate effective thermal conductivity should be chosen for use based on the expected fill gas for thermal evaluations of SNF containers.

The following recommendations should be followed when using the effective thermal conductivity data with finite element codes. It should be noted that only even mesh grids $(14 \times 14$ suggested for PWR assemblies and 10x10 suggested for BWR assemblies) should be used when using the effective thermal conductivity data and finite element codes. This mesh spacing places a local node at the center of the SNF assembly and will calculate a temperature at this location directly. If an odd spacing is used, the mesh will interpolate this point consistent with the finite element method. The PWR and BWR basket cell widths assumed for these analyses were 0.2235 meters ( 8.8 inches) and 0.1524 meters (6.0 inches), respectively. However, the size of the basket opening or the assembly should not affect the calculation or invalidate the effective thermal conductivity. The derivation of the effective thermal conductivity does not depend on the basket width; it is only an average thermal conductivity for the region being modeled. Also, increasing the gap between the SNF assembly and the basket wall should have a minimal effect since the heat transfer is predominately by radiation; however, this can be affected by fill gas conductivity. Generally, for reasonable basket designs, the 
gap size will not have a significant impact on the use of the effective thermal conductivity. When calculating the heat load to apply to the SNF region, use the cross sectional area or volume of the modeled region, not the area or volume of the SNF assembly. Using the SNF assembly area or volume will result in a larger heat load per volume for the modeled region and the calculation will over-predict the peak SNF cladding temperatures.

Temperature-dependent SNF effective thermal conductivities provide a simple method for calculating best estimate SNF peak cladding temperatures. The conductivities reported here were developed in a reproducible calculation with an industry standard code, with limited benchmarks to work previously performed within the Civilian Radioactive Waste Management System (CRWMS), such that some confidence can be given to these reported results. Preliminary results indicate that the effective thermal conductivities are suited for the thermal analysis of SNF container designs. 


\section{References}

1. Yucca Mountain Site Characterization Project Q-List, YMP/90-55Q, REV 3, U.S. Department of Energy (DOE) Office of Civilian Radioactive Waste Management (OCRWM).

2. Activity Evaluation: "Perform Criticality, Thermal, Structural, and Shielding Analyses", Document Identifier (DI) Number: BB0000000-01717-2200-00025 REV 02, Civilian Radioactive Waste Management System (CRWMS) Management and Operating Contractor (M\&O).

3. Quality Assurance Requirements and Description, DOE/RW-0333P, REV 5, U.S. DOE OCRWM.

4. Characteristics of Potential Repository Wastes, DOE/RW-0184-R1; Volume 1, U.S. DOE OCRWM, July 1992.

5. Heat Transfer from a Parallel-Rod Fuel Assembly in a Shipping Container, R. O. Wooton and H. M. Epstein, Battelle Memorial Institute, Columbus, Ohio, August, 1963.

6. Activity Evaluation: "Develop Technical Documents", DI Number: BB0000000-017172200-00007 REV 02, CRWMS M\&O.

7. Activity Evaluation: “Formal Review of Technical Documents", DI Number: BB000000001717-2200-00009 REV 03, CRWMS M\&O.

8. 1986 ASME Boiler and Pressure Vessel Code, Section III, The American Society of Mechanical Engineers, July 1, 1986.

9. Technical Document Preparation Plan for the Spent Nuclear Fuel Effective Thermal Conductivity Report, DI Number: BBA000000-01717-4600-00009 REV 01, CRWMS M\&O.

10. MATPRO - Version 11 (Revision 2), A Handbook of Materials Properties for Use in the Analysis of Light Water Reactor Fuel Rod Behavior, NUREG/CR-0497 TREE-1280, REV 2, U.S. DOE/E.G.\&G. Idaho National Engineering Laboratory, August 1981.

11. Introduction to Heat Transfer, F. P. Incropera and D. P. DeWitt, John Wiley \& Sons Inc., 1985.

12. Preliminary Waste Form Characteristics Report, Version 1.0, UCRL-ID-108314 REV 01, Lawrence Livermore National Laboratory (LLNL), October 1991.

13. Multi-Purpose Canister (MPC) Implementation Program Conceptual Design Phase Report, Volume II.A, DI Number: A20000000-00811-5705-00002 REV 00, CRWMS M\&O. 
14. Station Nuclear Engineering Manual, GE Mechanical \& Nuclear Engineering Training, NEDO-24810 / 80NED032, General Electric Co., September 1980.

15. Waste Package Tube Assembly Weldment (44-BWR), DI Number: BBA000000-01717-210015054 REV 00A, CRWMS M\&O, June 1994, RPC Batch Number: MOY-960314-12, RPC Accession Number: MOL.19960619.0012-0133.

16. Engineered Barrier Design Requirements Document, YMP/CM-0024, REV 0, ICN 1, Yucca Mountain Site Characterization Project.

17. Waste Package Development Technical Document, DI Number: BBA000000-01717-570500009 REV 01, CRWMS M\&O.

18. Controlled Design Assumptions Document, DI Number: B00000000-01717-4600-00032 REV 03, CRWMS M\&O (TBV-221-DD).

19. Site Characterization Plan Thermal Goals Reevaluation, DI Number: B00000000-017175705-00005 REV 00, CRWMS M\&O.

20. BWR Spent Fuel Storage Cask Performance Test; Volume I; Cask Handling Experience and Decay Heat, Heat Transfer, and Shielding Data, PNL-5777-Vol. I, Pacific Northwest Laboratory (PNL), February 1986.

21. BWR Spent Fuel Storage Cask Performance Test; Volume II; Pre-and Post-Test Decay Heat, Heat Transfer, and Shielding Analyses, PNL-5777-Vol.II, Pacific Northwest Laboratory (PNL), June 1986.

22. Spent Nuclear Fuel Storage - Performance Tests and Demonstrations, PNL-8451, Pacific Northwest Laboratory (PNL), April 1993.

23. The TN-24P PWR Spent-Fuel Storage Cask: Testing and Analysis, EPRI NP-5128, PNL6054, PNL/Virginia Power Company/EG\&G, Idaho National Engineering Laboratory (INEL), April 1987.

24. The Castor-V21 PWR Spent-Fuel Storage Cask: Testing and Analysis, EPRI NP-4887, PNL5917, Virginia Power Company/PNL/EG\&G, INEL, November 1986.

25. The MC-10 PWR Spent-Fuel Storage Cask: Testing and Analysis, EPRI NP-5268, PNL6139, PNL/Virginia Power Company/EG\&G, INEL, July 1987.

26. Emplacement Scale Thermal Evaluations of Large and Small WP Designs, DI Number: BB0000000-01717-0200-00009 REV 00, CRWMS M\&O. 
27. Waste Package Tube Assembly Weldment (21-PWR), DI Number: BBA000000-01717-210015061 REV 00A, CRWMS M\&O, June 1994, RPC Batch Number: MOY-960314-12, RPC Accession Number: MOL.19960619.0012-0133.

28. Thermal Evaluation of the Conceptual 21 PWR UCF Tube Basket Design Disposal Container, DI Number: BBAA00000-01717-0200-00003 REV 00, CRWMS M\&O.

29. Thermal Evaluation of the Conceptual 44 BWR UCF Tube Basket Design Disposal Container, DI Number: BBAA00000-01717-0200-00001 REV 00, CRWMS M\&O.

30. Technical Basis for Storage of Zircaloy-Clad Spent Nuclear Fuel in Inert Gases, A. B. Johnson Jr., E. R. Gilbert, PNL-4835, PNL, September 1983.

31. COBRA-SFS: A Thermal-Hydraulic Analysis Computer Code, PNL-6049 Vols. I-III UC-85, U.S. DOE/PNL, November 1986.

32. BR-100 ton Rail/Barge Spent Fuel Shipping Cask, Final Design Package, No. 51-120340001, B\&W Fuel Company, November 1991.

33. GA-4 Legal Weight Truck From-Reactor Spent Fuel Shipping Cask, 910353/0, U.S. DOE/OCRWM/General Atomics, December 1993.

34. GA-9 Legal Weight Truck From-Reactor Spent Fuel Shipping Cask, 910354/0, U.S. DOE/Idaho Operations Office/General Atomics, September 1993.

35. Mined Geologic Disposal System Multi-Purpose Canister Design Considerations Report, Section 2 of the Multi-Purpose Canister (MPC) Implementation Program Conceptual Design Phase Report, Volume V, DI Number: A20000000-00811-5705-00008 REV 00, CRWMS $\mathrm{M} \& \mathrm{O}$.

36. Waste Package Design Status Report, Fiscal Year 1993, DI Number: B00000000-017175705-00007 REV 00, CRWMS M\&O.

37. Safety Analysis Report for the NAC Storable Transport Cask, No.71-9235, Rev. 2, Nuclear Assurance Corporation, Norcross, Georgia, July 1993.

38. Spent Nuclear Fuel Assembly Thermal Model, DI Number: BBA000000-01717-4200-00009 REV 00, CRWMS M\&O.

39. Conceptual Waste Package Designs for Disposal of Nuclear Waste in Tuff, ONWI-439, J. R. Schornhorst, et al, Westinghouse Electric Corporation AESD, Pittsburgh, PA, April 1983.

40. Thermal Modeling of Nuclear Waste Package Designs for Disposal in Tuff, UCRL-89820, J. N. Hockman, W. C. O'Neal, LLNL, February 1984. 
41. Thermal Performance of a Buried Nuclear Waste Storage Container Storing a Hybrid Mix of PWR and BWR Spent Fuel Rods, UCID-21414 Rev. 1, G. L. Johnson, LLNL, November 1991.

42. Determination of Effective Thermal Conductivity for a Full-Scale Mock-Up of a 217-Element Breeder Reactor Fuel Assembly Subjected to Normal Shipping Conditions, SAND85-2827, L. C. Sanchez, M. L. Hudson, Sandia National Laboratories (SNL), December 1986.

43. Effective Thermal Conductivity of Debris Beds, I. Cook and R. S. Peckover, Proceedings of the Fifth Post Accident Heat Removal Information Exchange Meeting, July 1982, pp. 40-45.

44. Conduction of Heat in Solids, Second Edition, H. S. Carslaw, J. C. Jaeger, Oxford University Press, 1959.

45. An Experimental Study of Natural Convection In Horizontal Rod-Bundle Enclosures, M.S. Thesis, T. E. Dalton, Department of Mechanical and Aerospace Engineering, University of Tennessee, Knoxville, Tennessee, December 1994.

46. Data Reduction and Error Analysis for the Physical Sciences, P. R. Bevington, McGraw-Hill Book Co., 1969.

47. Initial Review/Analysis of Thermal and Neutronic Characteristics of Potential MPC/WP Filler Materials, DI Number: BBA000000-01717-5705-00001 REV 00, CRWMS M\&O.

48. Determination of PWR SNF Effective Conductivity, DI Number: BBA000000-01717-020000007 REV 01, CRWMS M\&O.

49. Determination of $7 x 7$ Rod Array BWR SNF Assembly Effective Thermal Conductivity, DI Number: BBA000000-01717-0200-00015 REV 00, CRWMS M\&O.

50. Determination of $8 x 8$ Rod Array BWR SNF Assembly Effective Thermal Conductivity, DI Number: BBA000000-01717-0200-00017 REV 00, CRWMS M\&O.

51. Determination of 9x9 Rod Array BWR SNF Assembly Effective Thermal Conductivity, DI Number: BBA000000-01717-0200-00018 REV 00, CRWMS M\&O. 


\section{Spent Nuclear Fuel Effective Thermal Conductivity Report}

\section{Robert H. Bahney III Thomas L. Lotz Thomas W. Doering August 7, 1996}

B\&W Federal Services

Duke Engineering \& Services, Inc. Fluor Daniel, Inc.

Framatome Cogema Fuels

Integrated Resources Group

INTERA, Inc.

JAI Corporation
JK Research Associates, Inc.

Kiewit/Parsons Brinkerhoff

Lawrence Berkeley Laboratory

Lawrence Livermore National Laboratory

Los Alamos National Laboratory

Morrison-Knudsen Corporation
Science Applications International Corporation Sandia National Laboratories

TRW Environmental Safety Systems Inc.

Woodward-Clyde Federal Services

Winston \& Strawn

Cooperating Federal Agency: U.S. Geological Survey 


\section{Description of Deliverable}

ALT6226 - Waste Package Thermal Conductivity Methods Analysis

Completion Criteria:

"Defines the methods for performing future waste package thermal analyses. Establishes an effective thermal conductivity for spent nuclear fuel in waste package designs." 


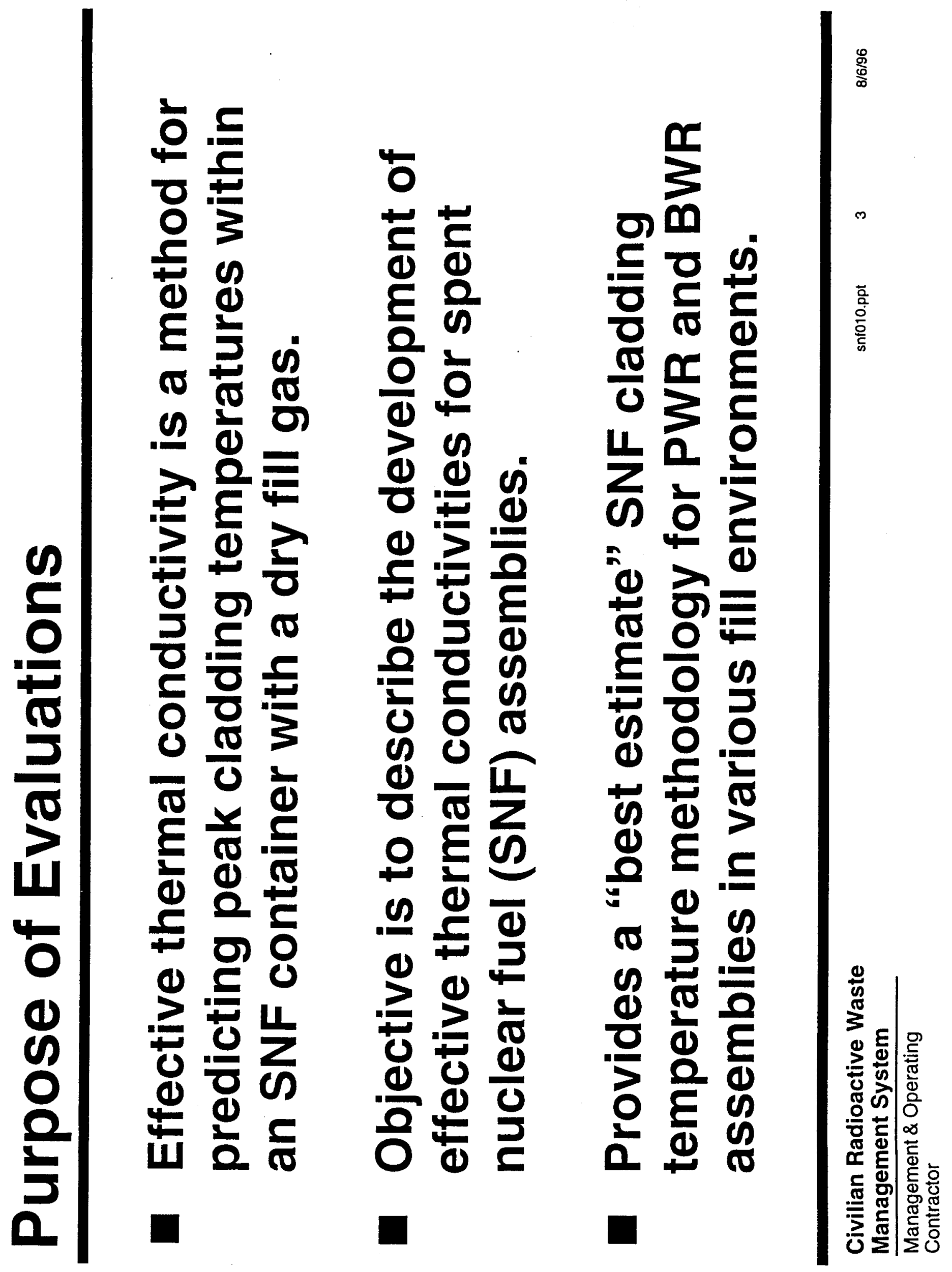




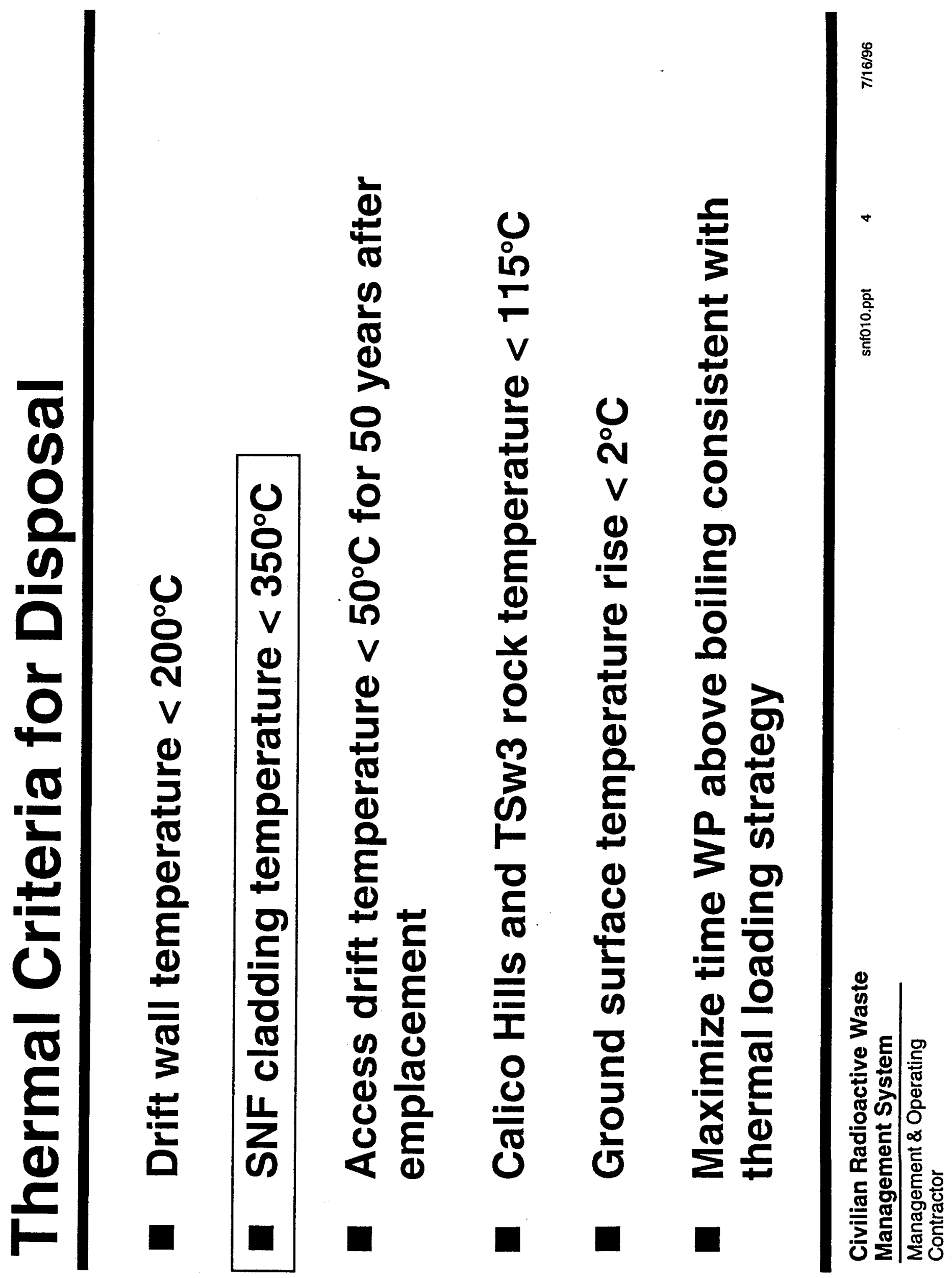




\section{Four Model Thermal Analysis Approach}
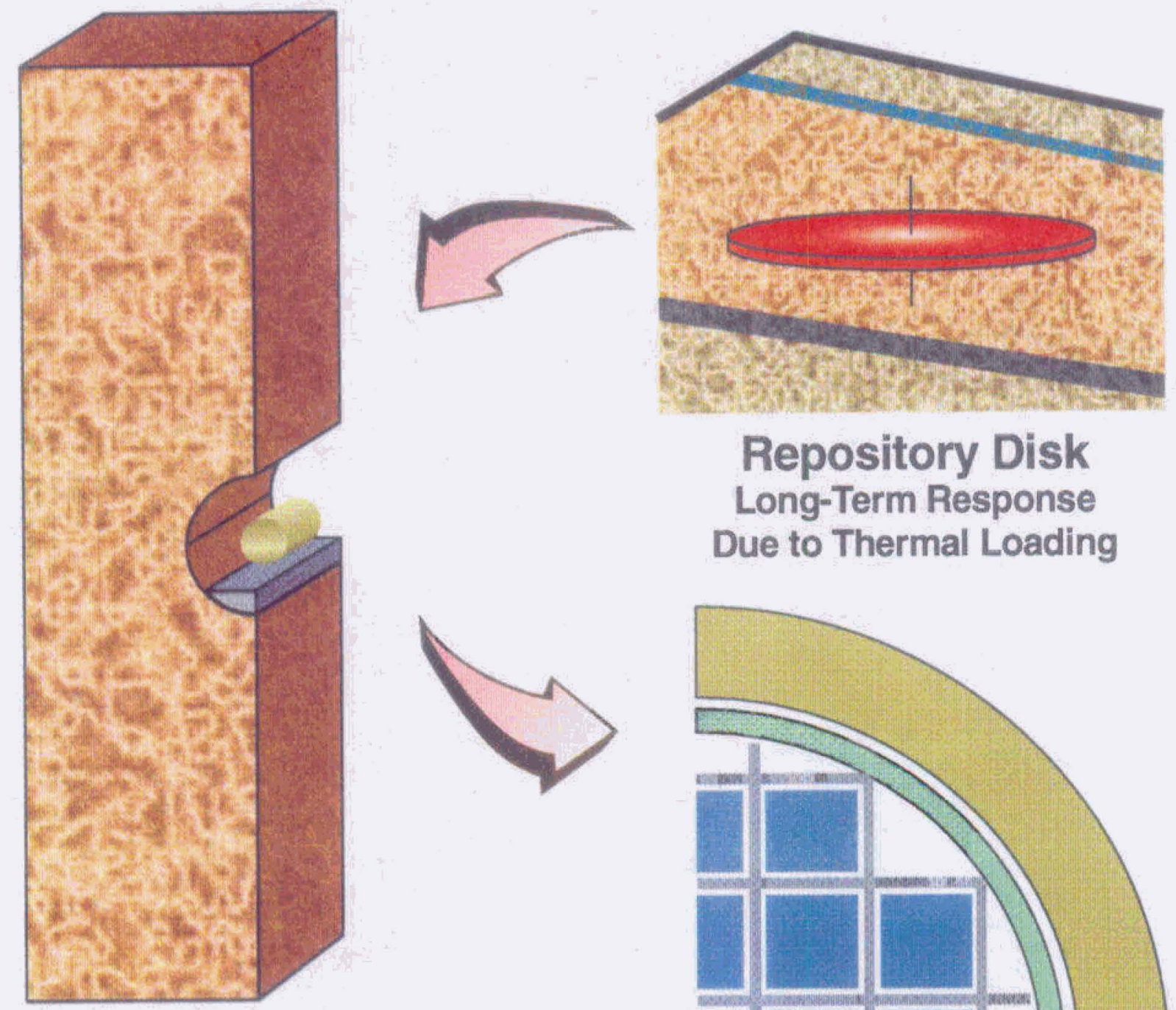

Drift Emplacement

Provide Time-Dependent

Boundary Conditions

for Near-Field
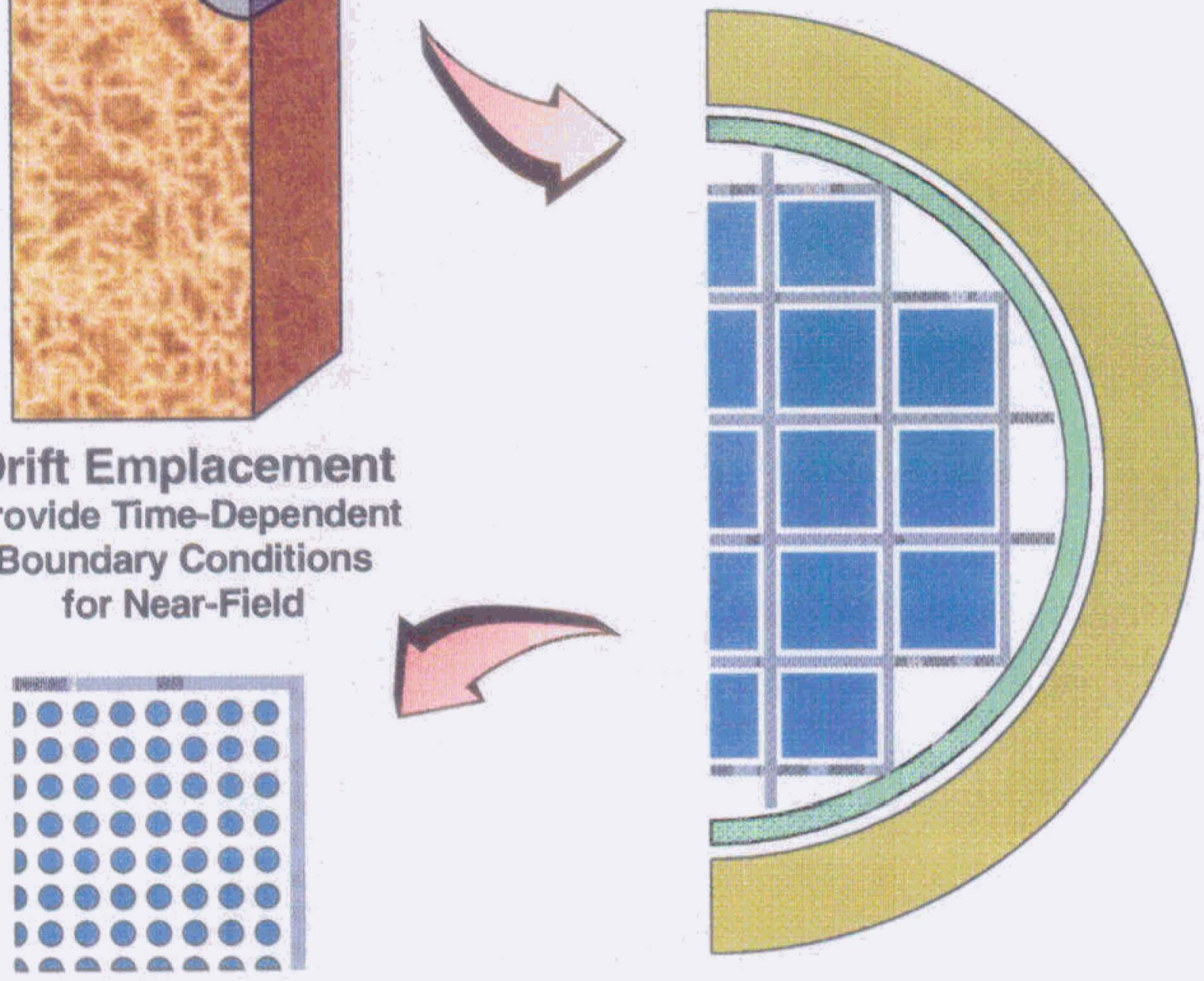

\section{1/4 SNF Assembly}

Peak Cladding Temperatures

(Effective Conductivity)

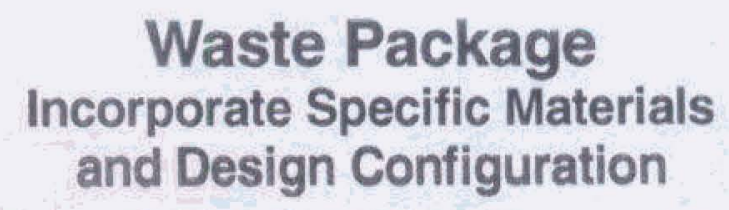




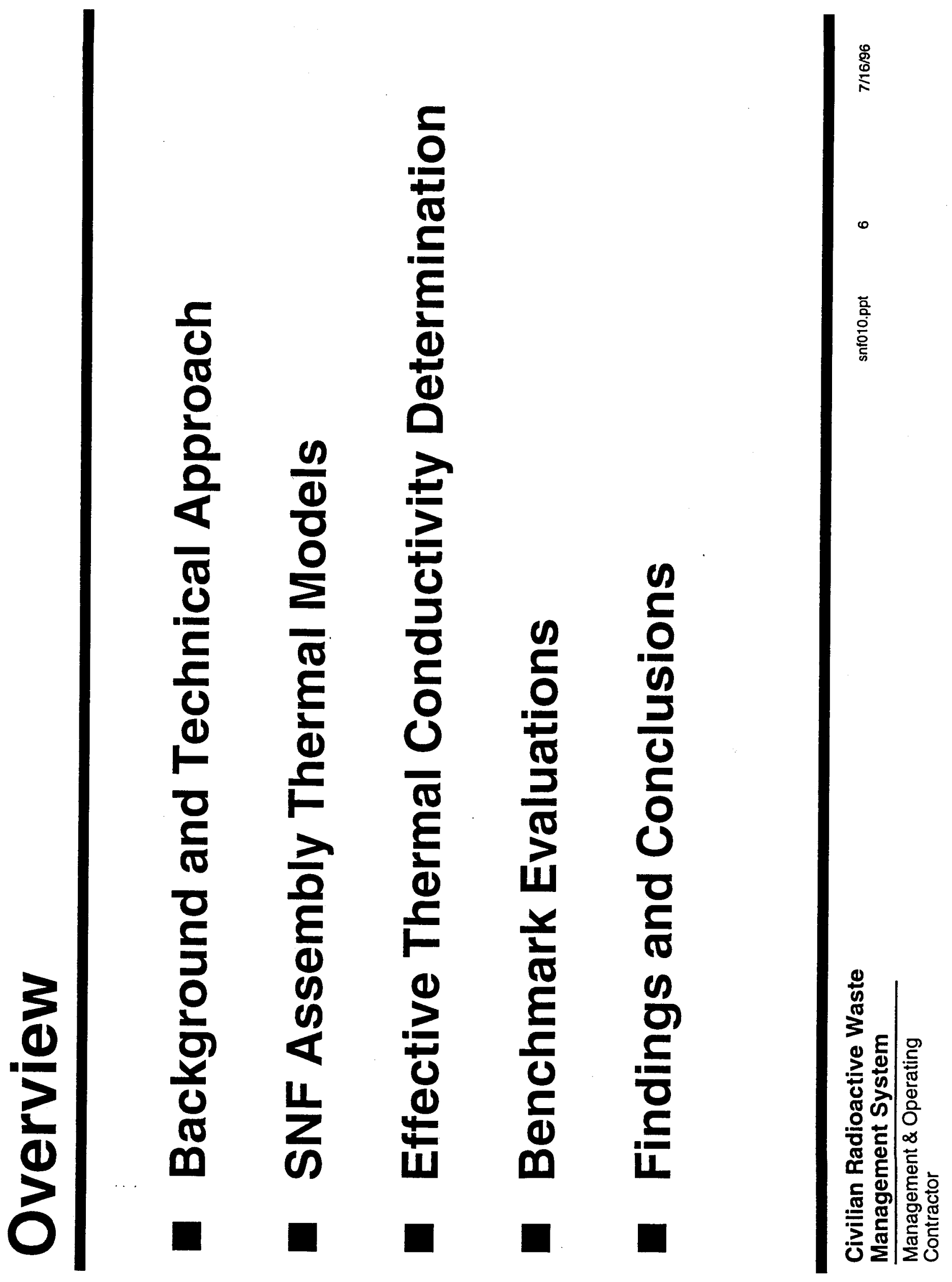




\section{Cladding Temperature Estimation Methods}

- Explicit model of every rod and heat transfer mechanism

Most accurate estimation

Costly in setup and computational time III-suited for parametric evaluation

- Empirical correlation (Wooton-Epstein)

Conservative estimation Limited range of applicability Multiple calculation steps 


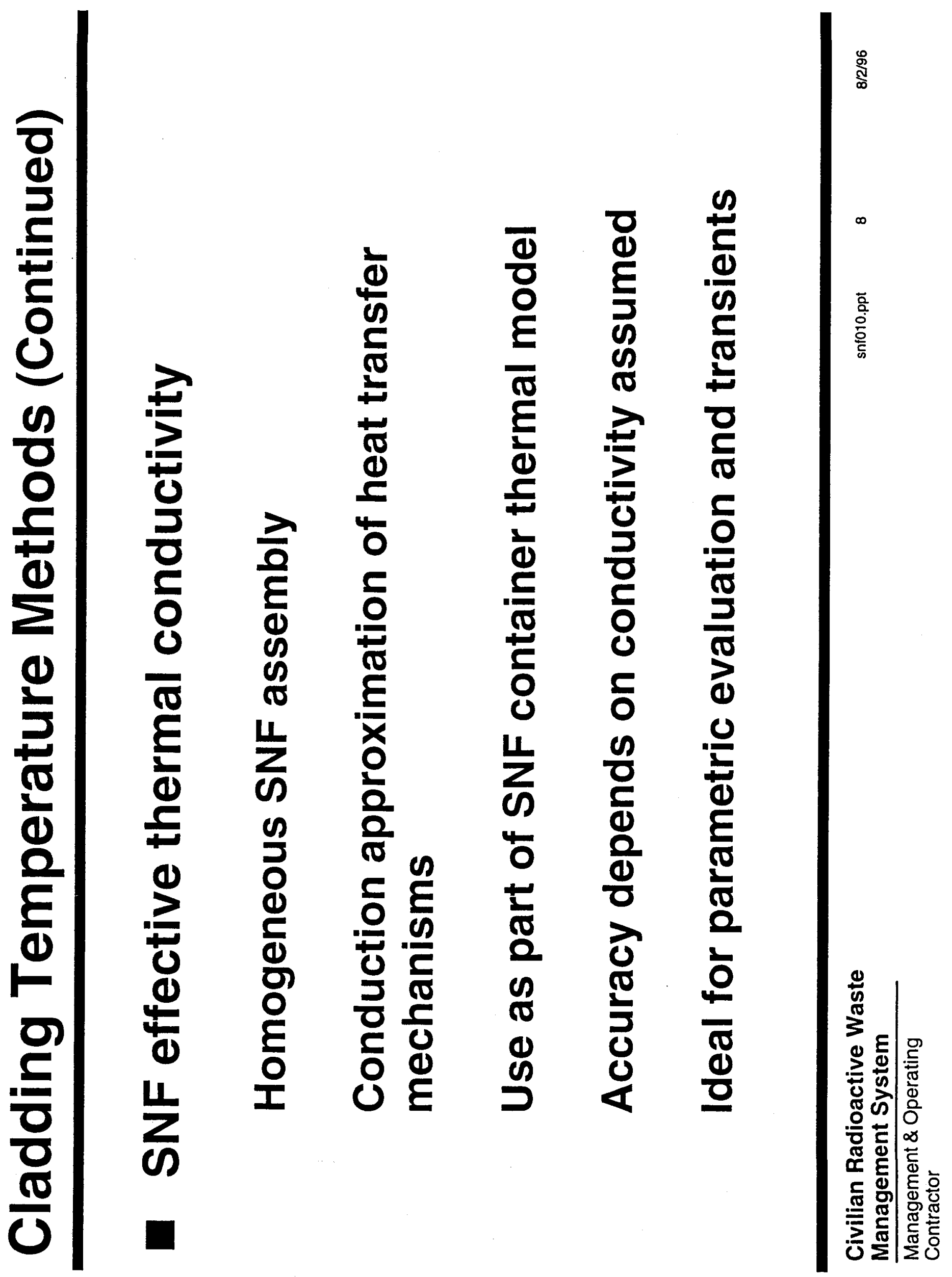




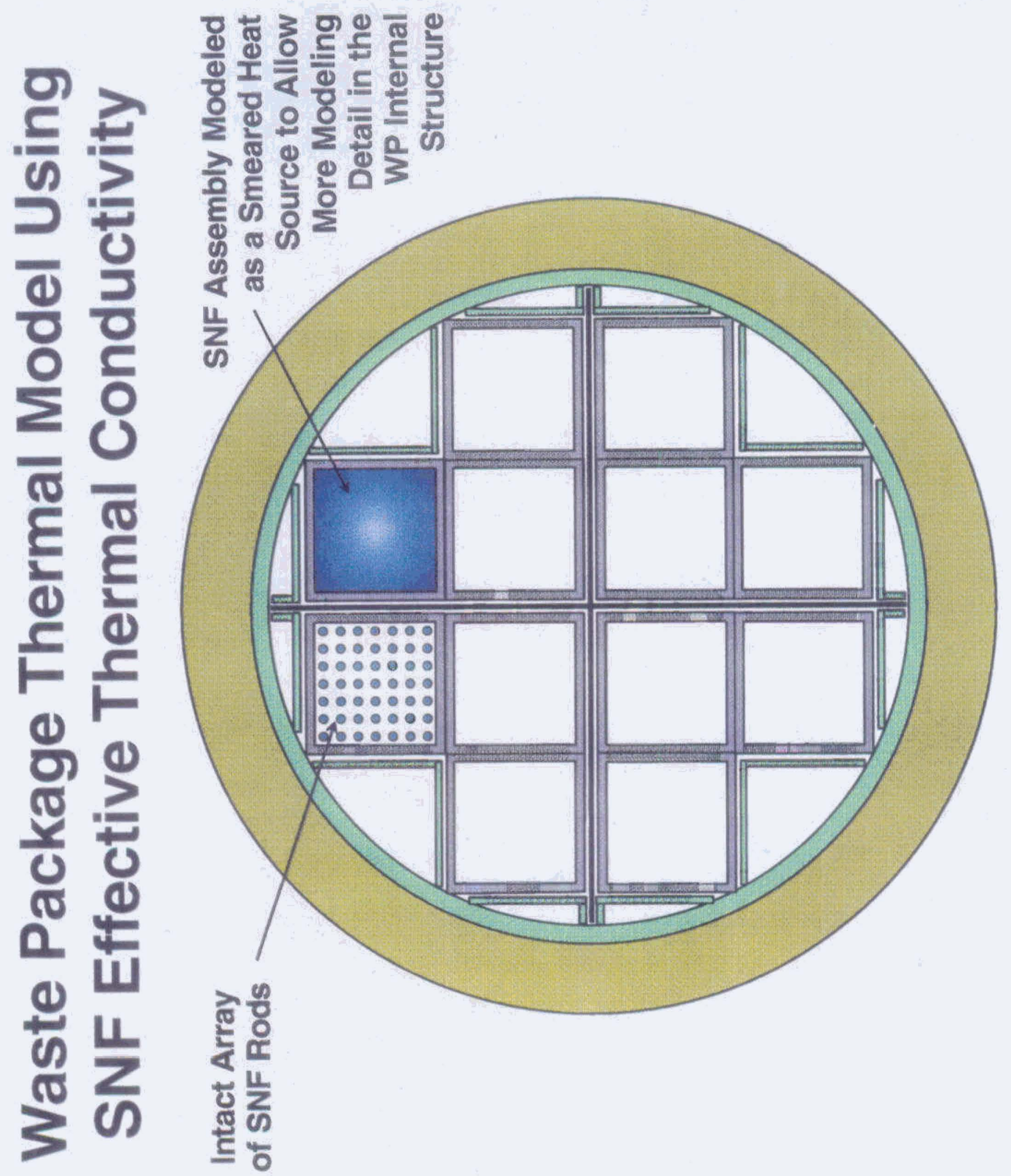




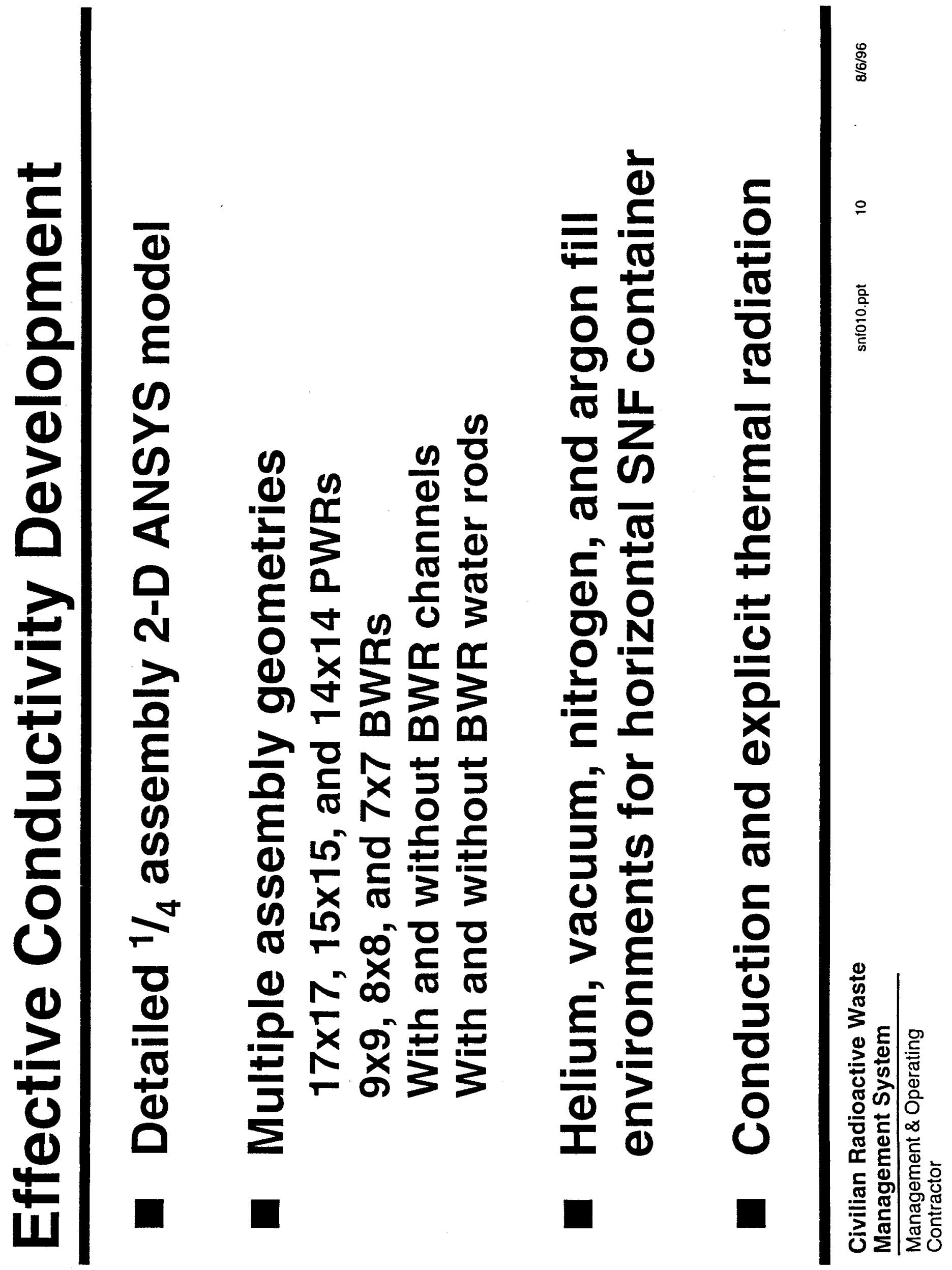




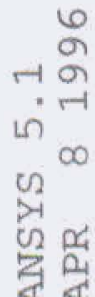

(1)

Hु 0

(o) $U 2$

(4) 1

(1) (1)

م. 4

है

E-1
ONOHNMM II

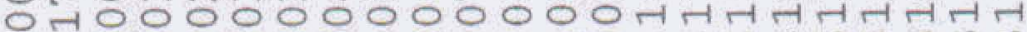

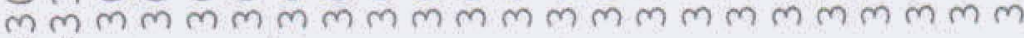
g. $\subseteq \frac{4}{2}$

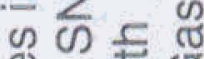

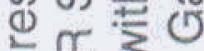

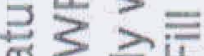

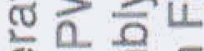

का है

은등

$E \bar{x}$

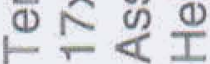




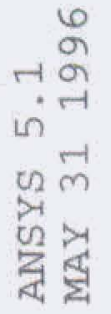

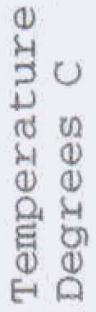

QHOHHNNM

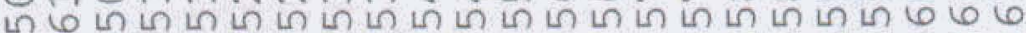

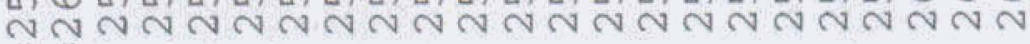
,

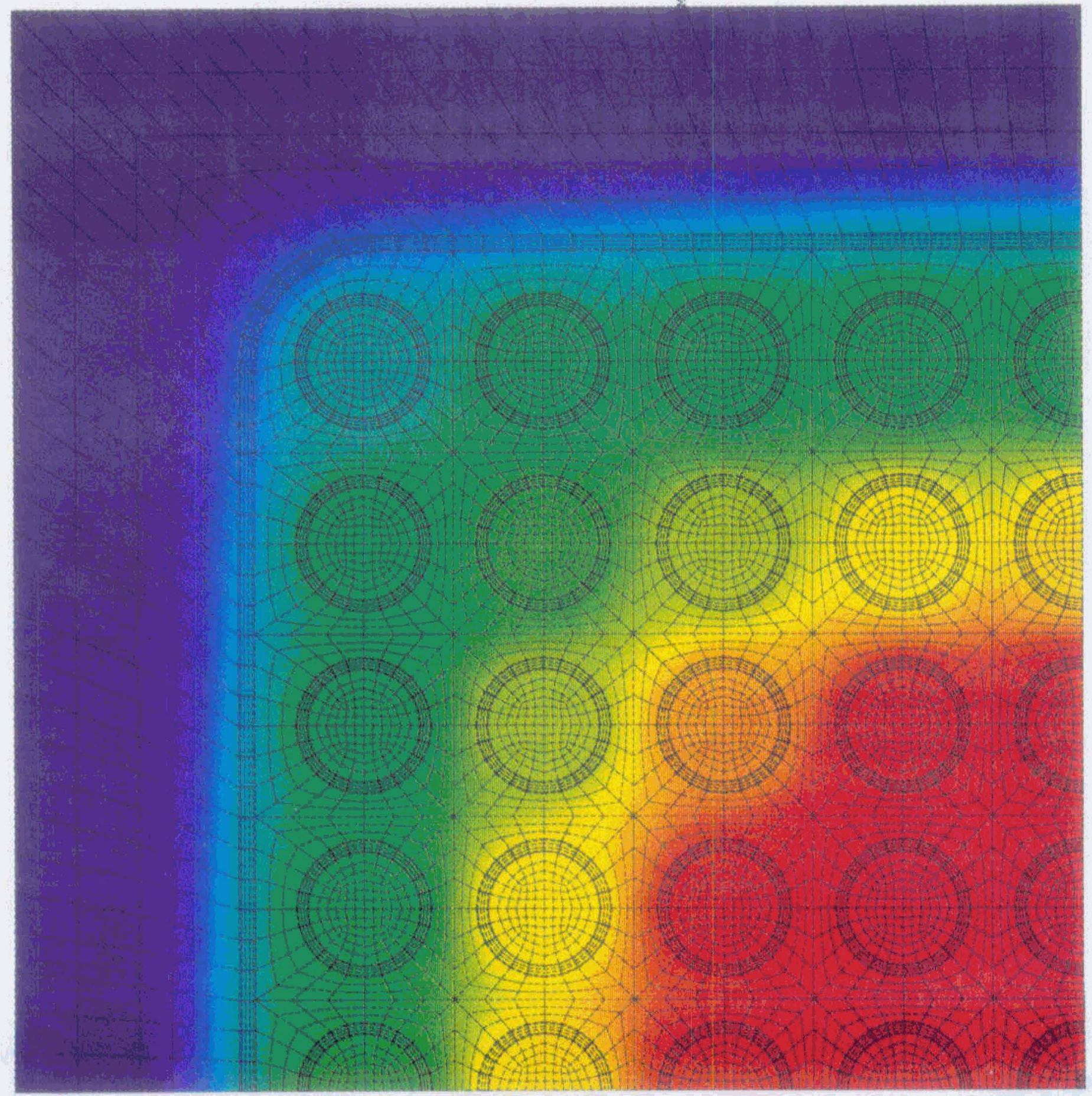




\section{SNF Assembly Thermal Model Results}

- Evaluated over a parametric range:

$25,50,100,150,200,250,300,350,400^{\circ} \mathrm{C}$

250, 500, 750, 1000 watts for PWRs

$100,200,300,400,500,600$ watts for BWRs

- Results indicate that detailed SNF model provides "best estimate" of cladding temperatures

- Cladding to basket temperature drop is non-linear function of SNF basket temperature (due to radiation component) and decay heat of assembly

- Alternate Wooton-Epstein calculation predicts about twice the temperature drop for helium fill gas 


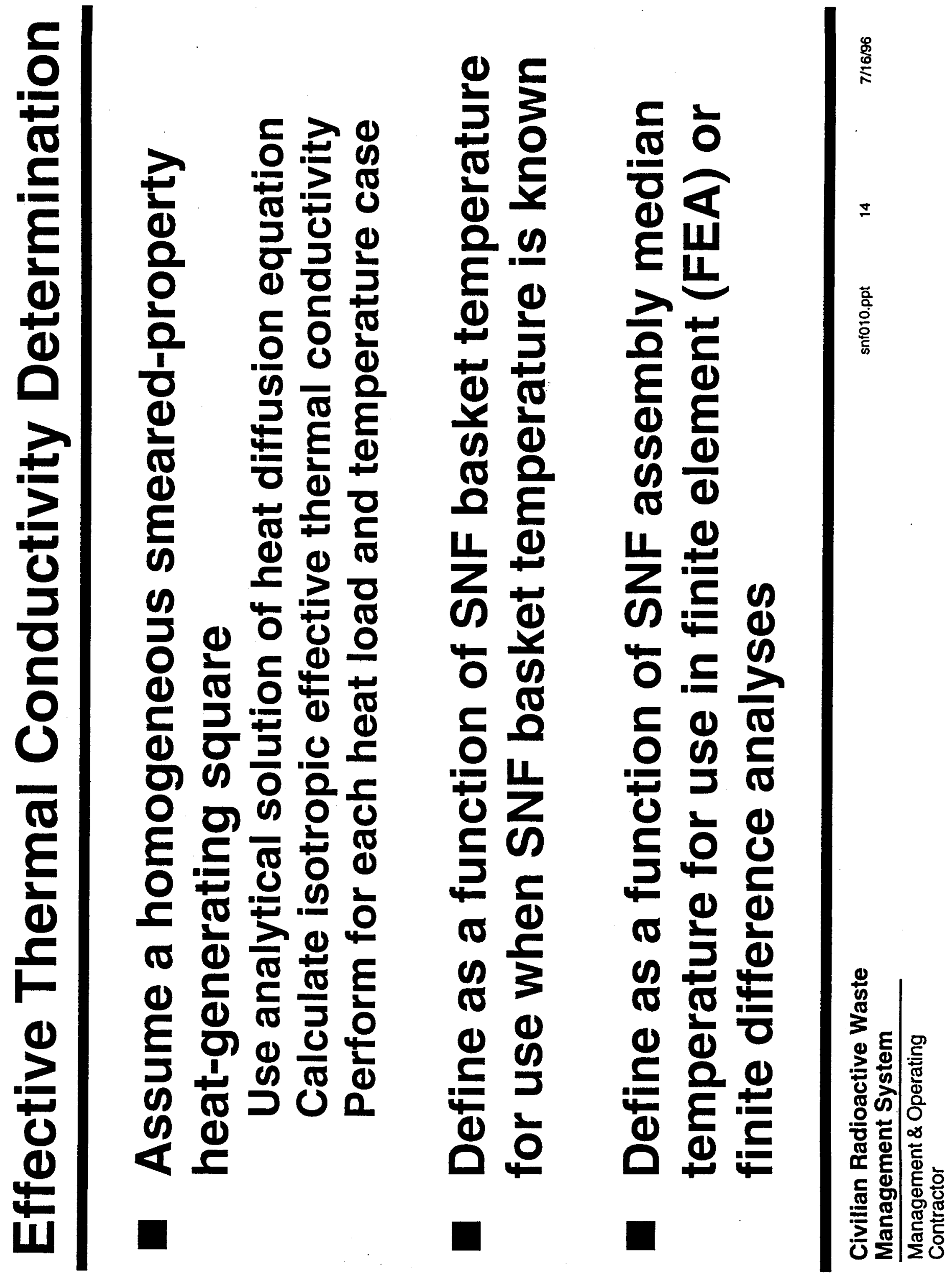




\section{PWR Effective Thermal Conductivities}

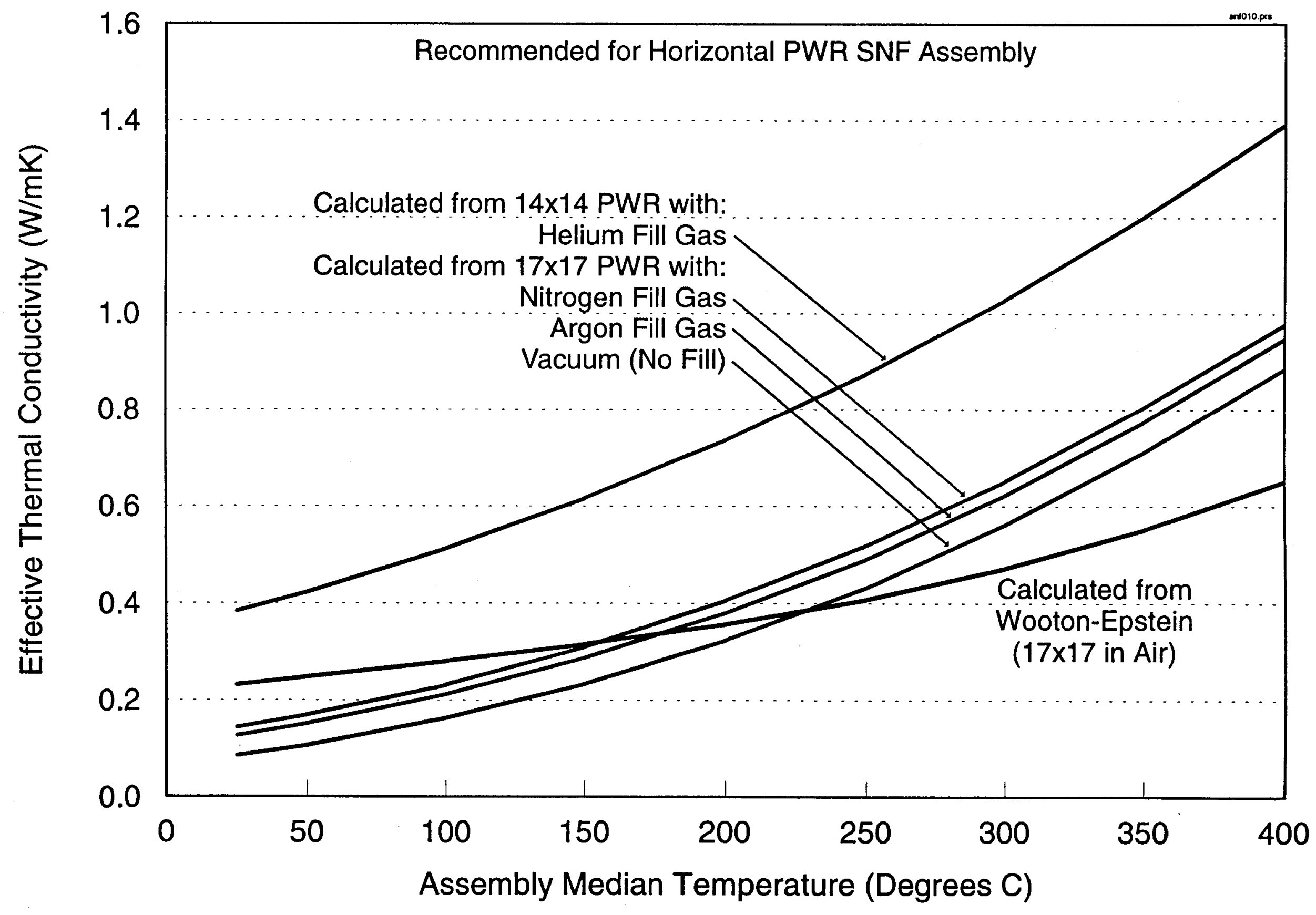




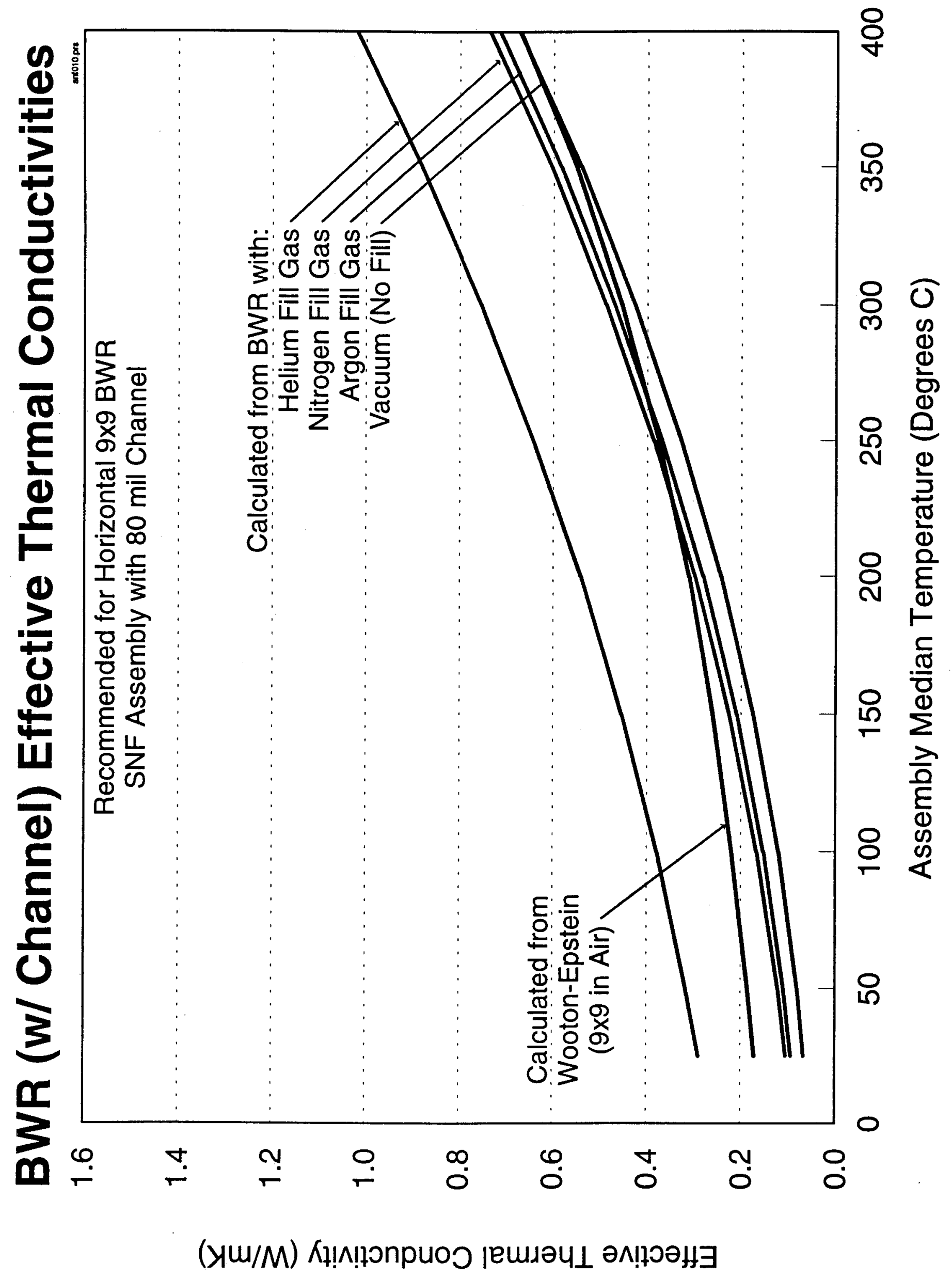




\section{BWR (No Channel) Effective Thermal Conductivities}

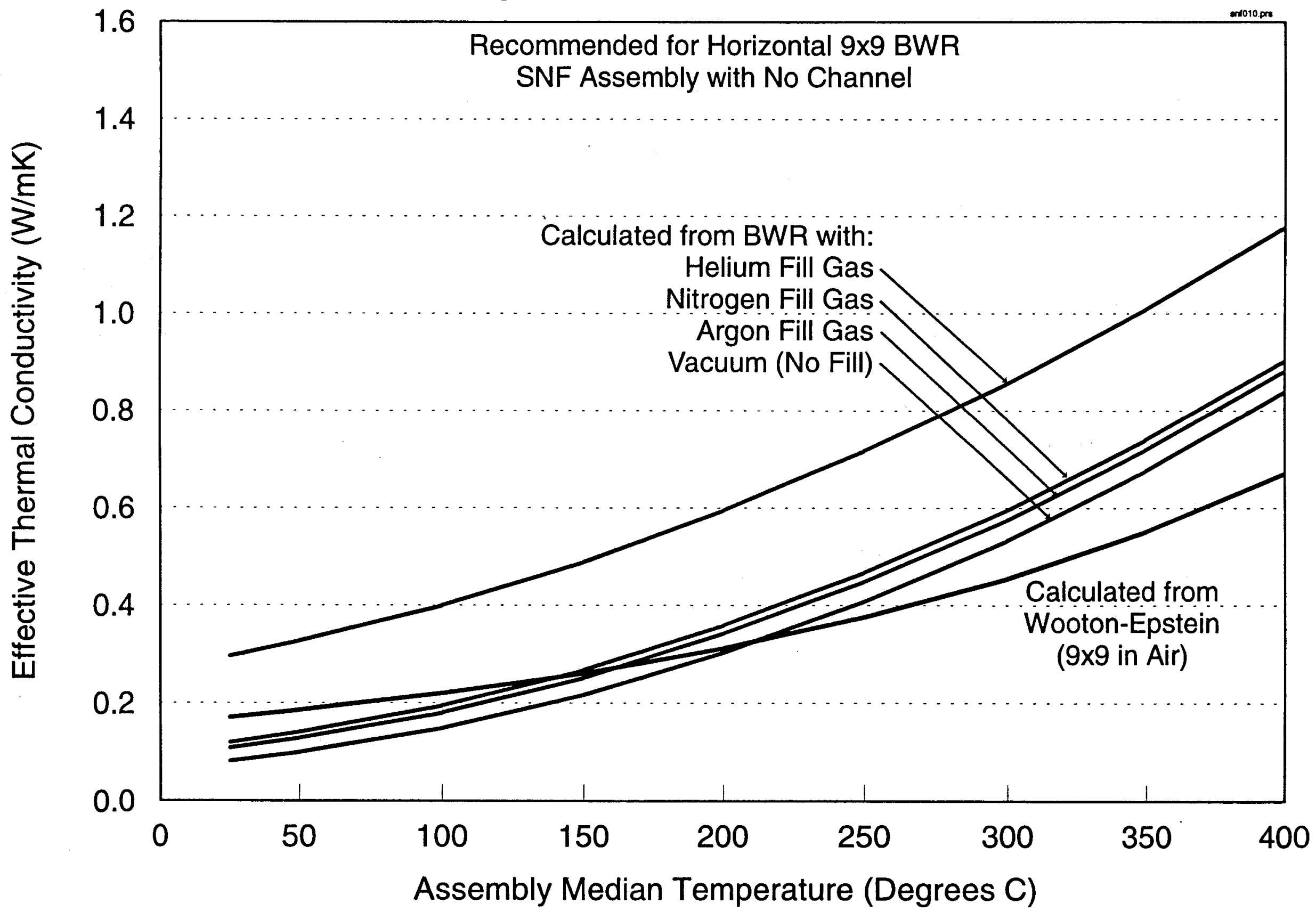




\section{Effective Conductivity Comparison for Helium}

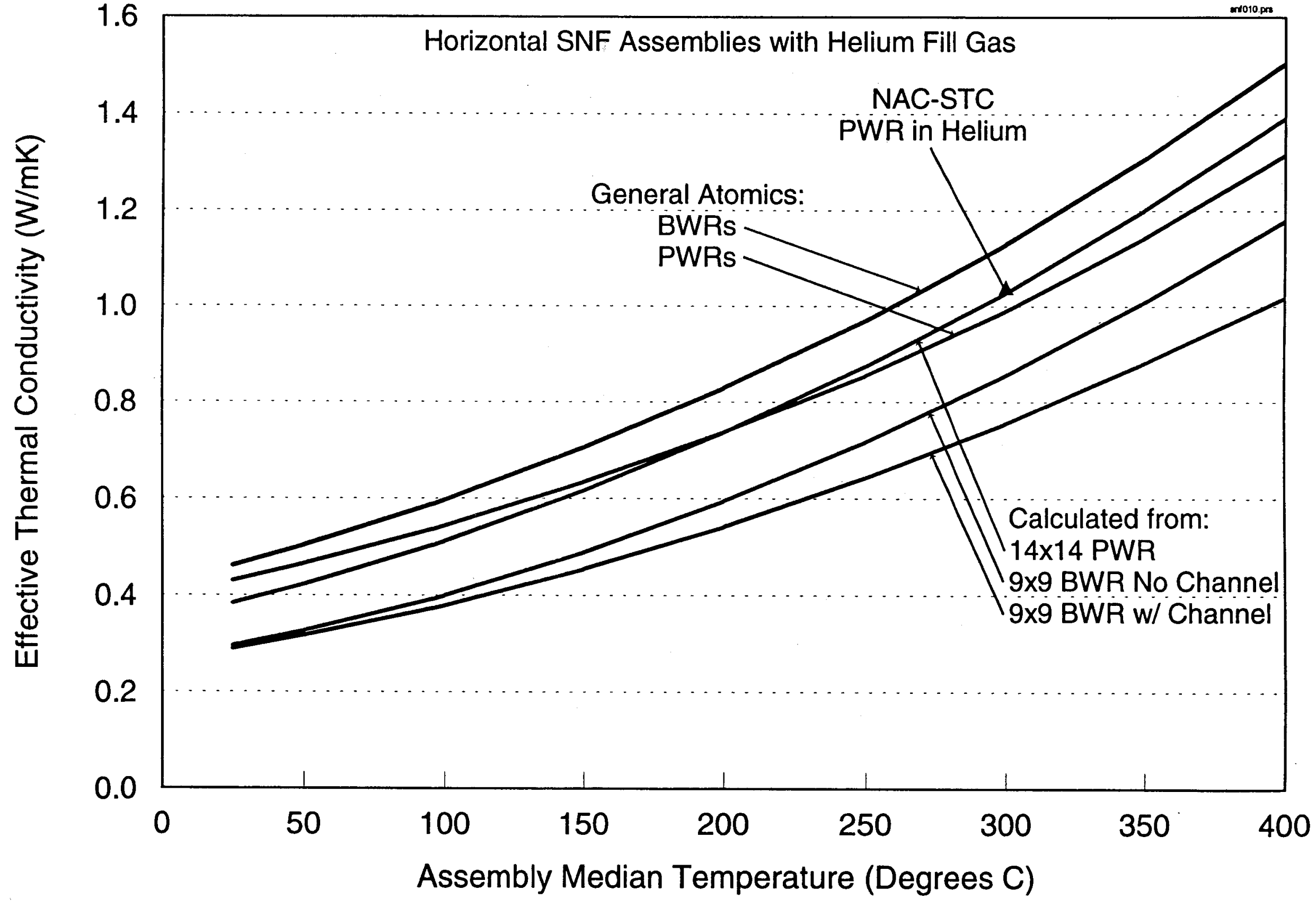




\section{Effective Conductivity Comparison for Nitrogen}

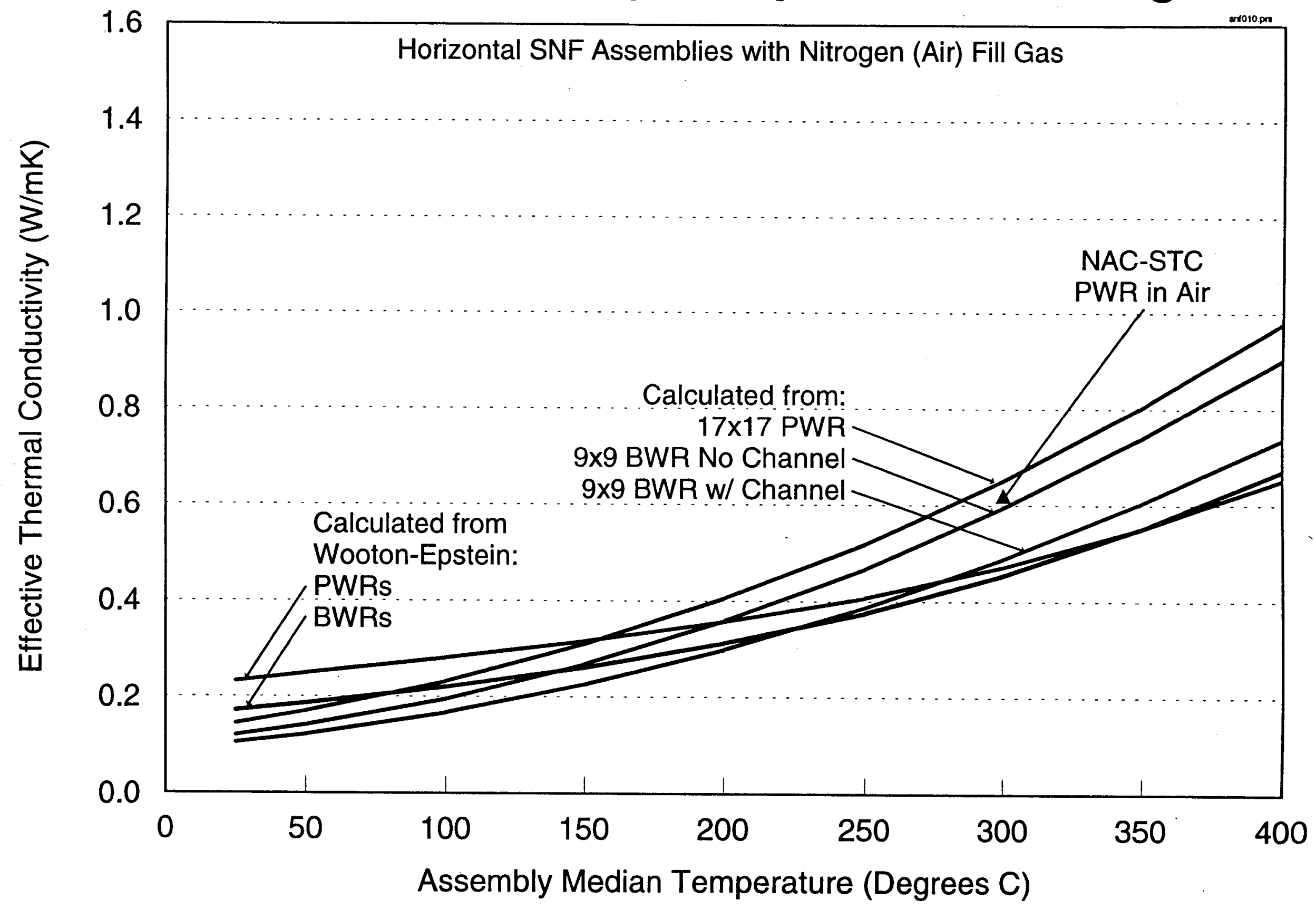


6
oे
음

เก

ज ल

군

है

瓜要
选U เ

(4)

पै 1

단

हैं

ह- Eिष

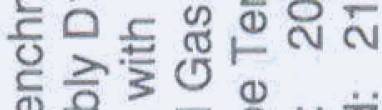

NHmサI I

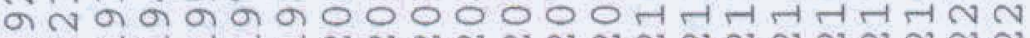

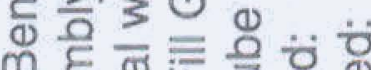
HNHनतम

世记 \& क क ह

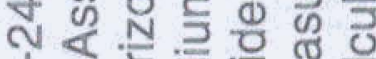
g.

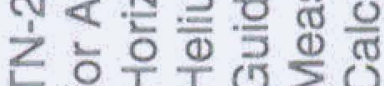

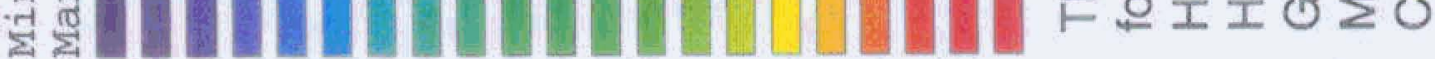

द
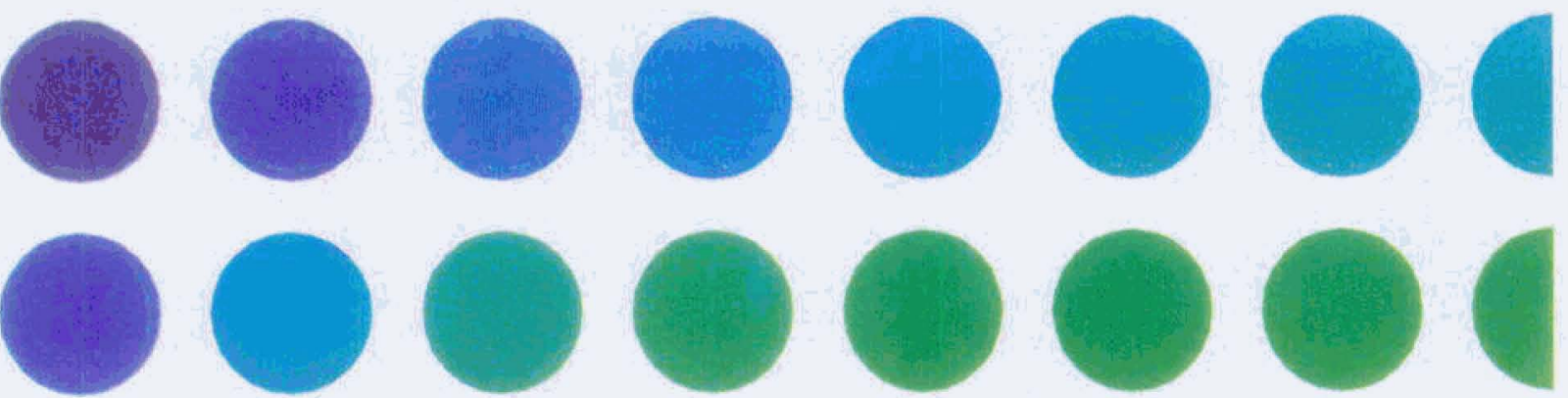

$+\overrightarrow{0}$
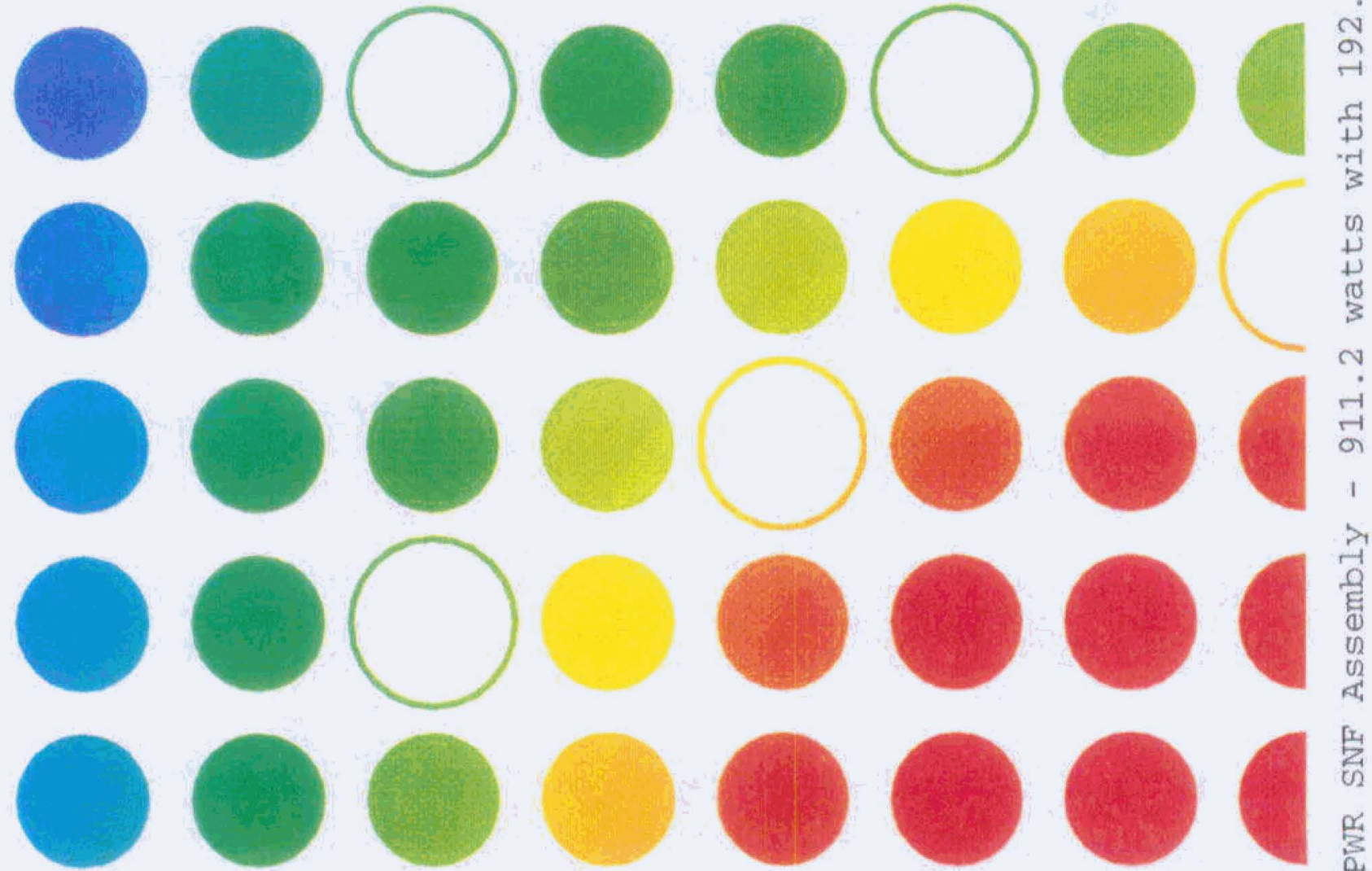

党
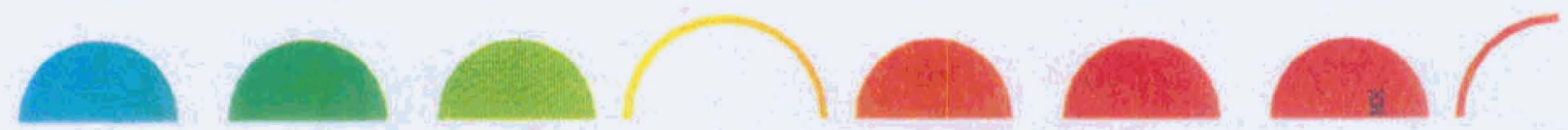

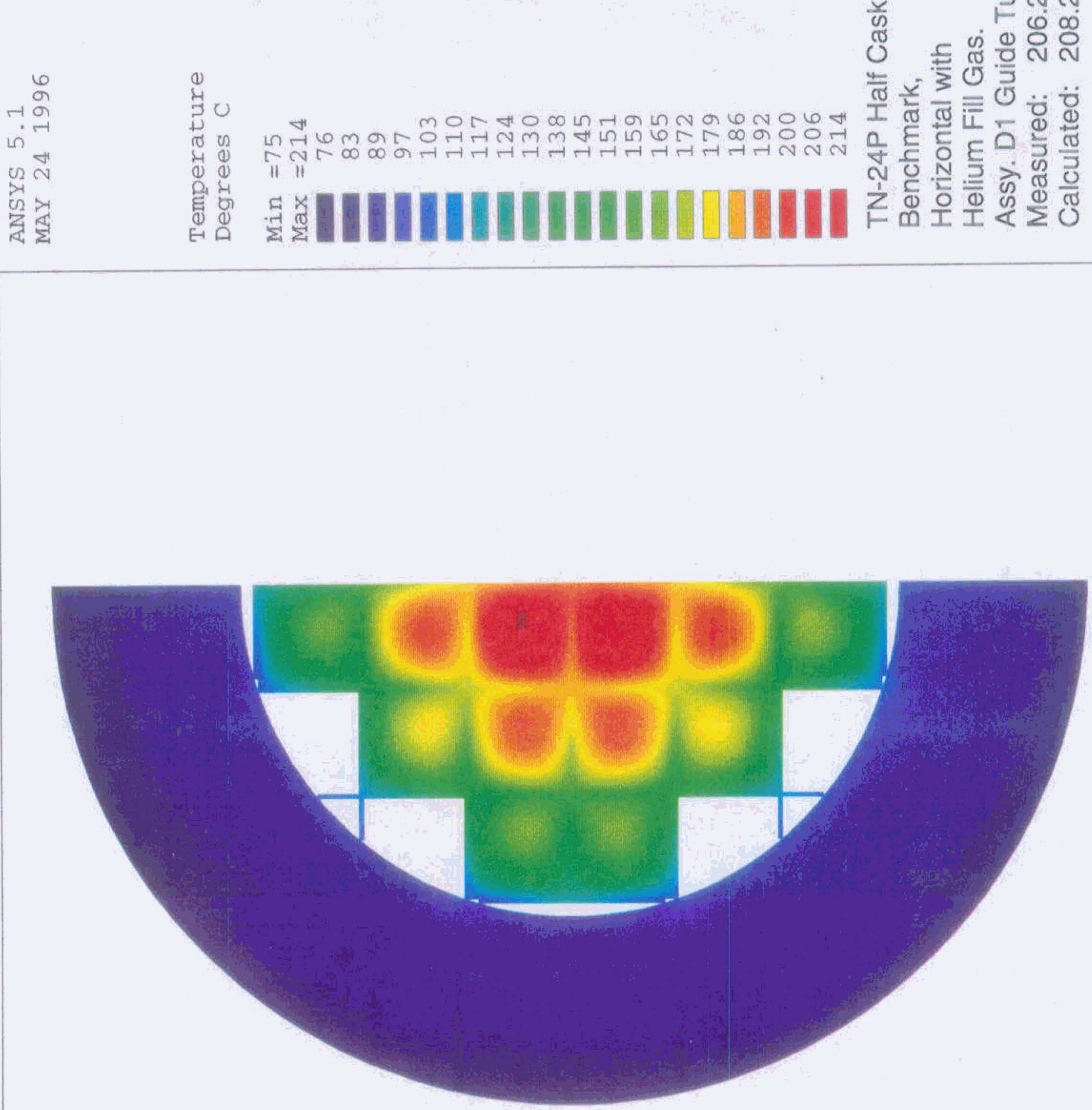


\section{Findings and Conclusions}

- Temperature-dependent SNF assembly effective thermal conductivities developed to provide a simple method for calculating a "best estimate" of SNF peak cladding temperature

- Benchmark results agreed with reported SNF storage cask testing

- Reproducible calculation using an industry standard code (ANSYS) 

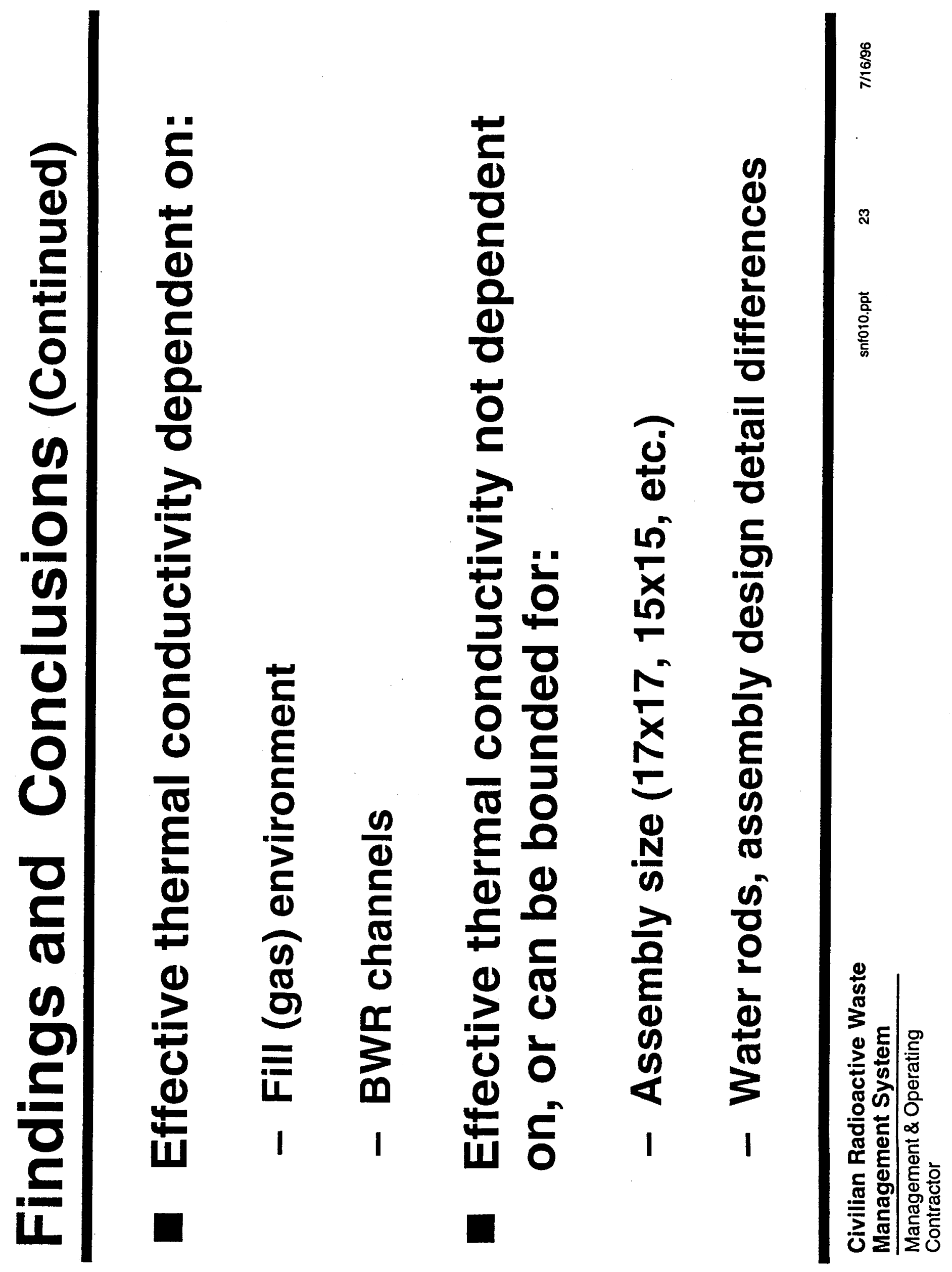


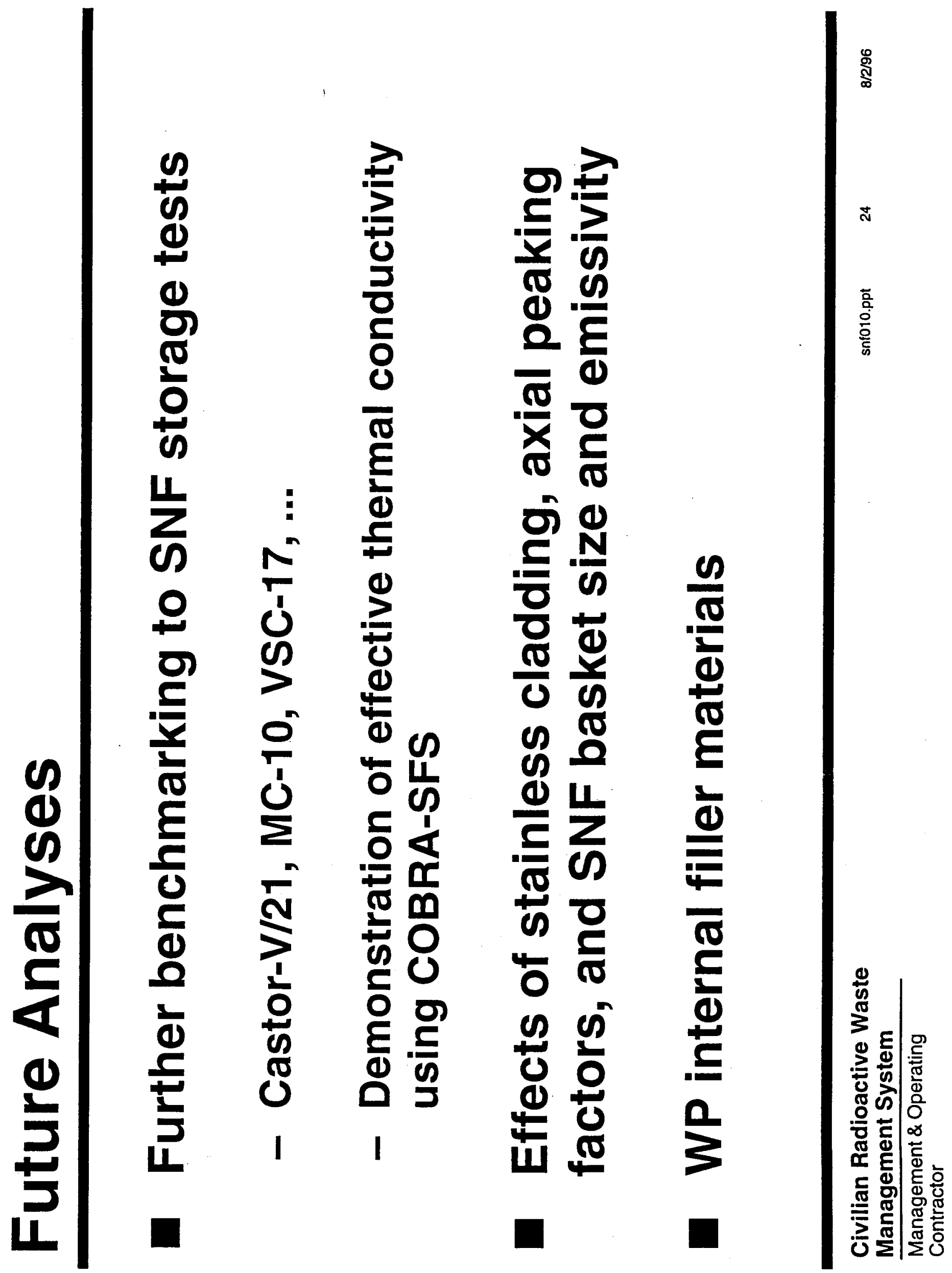




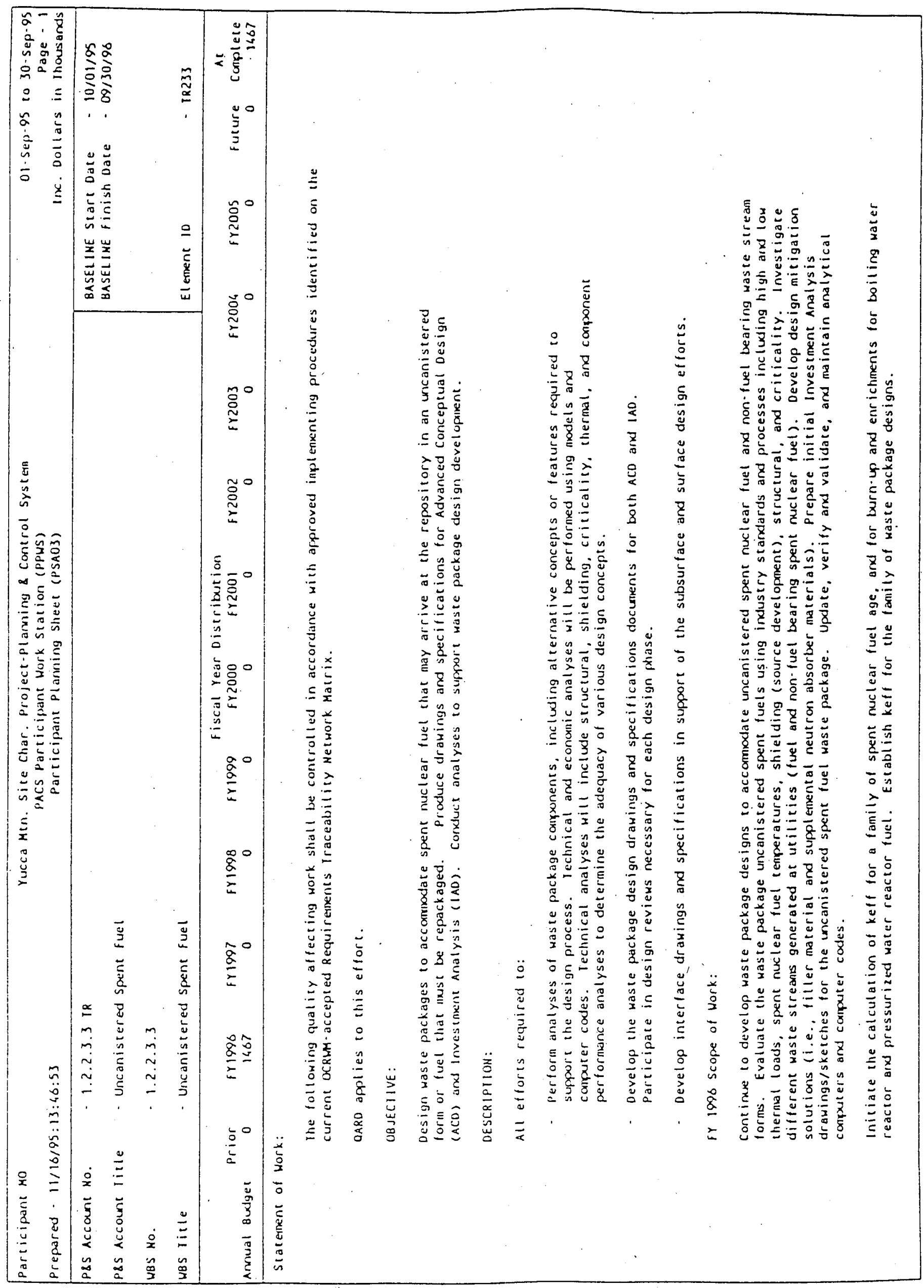




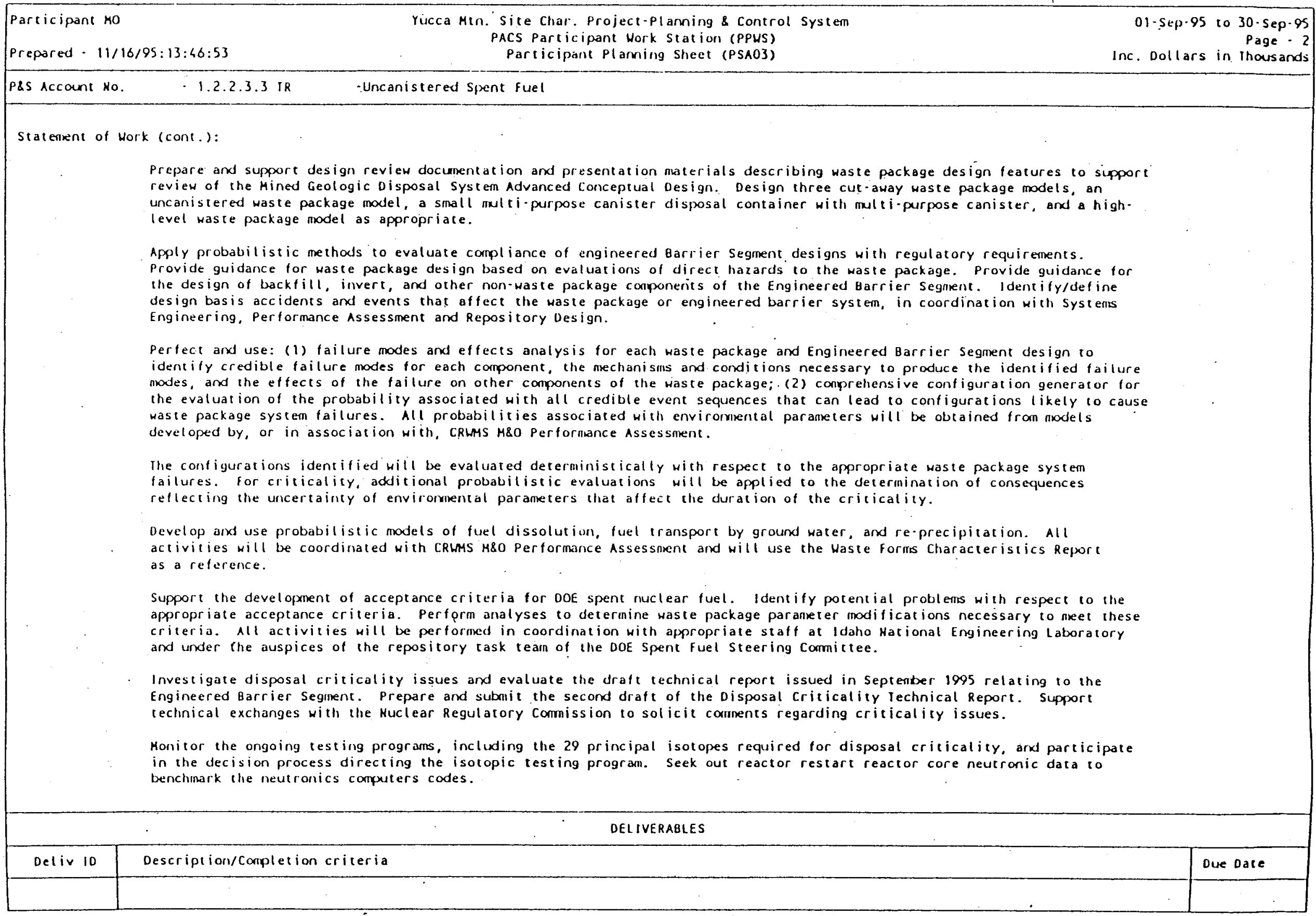




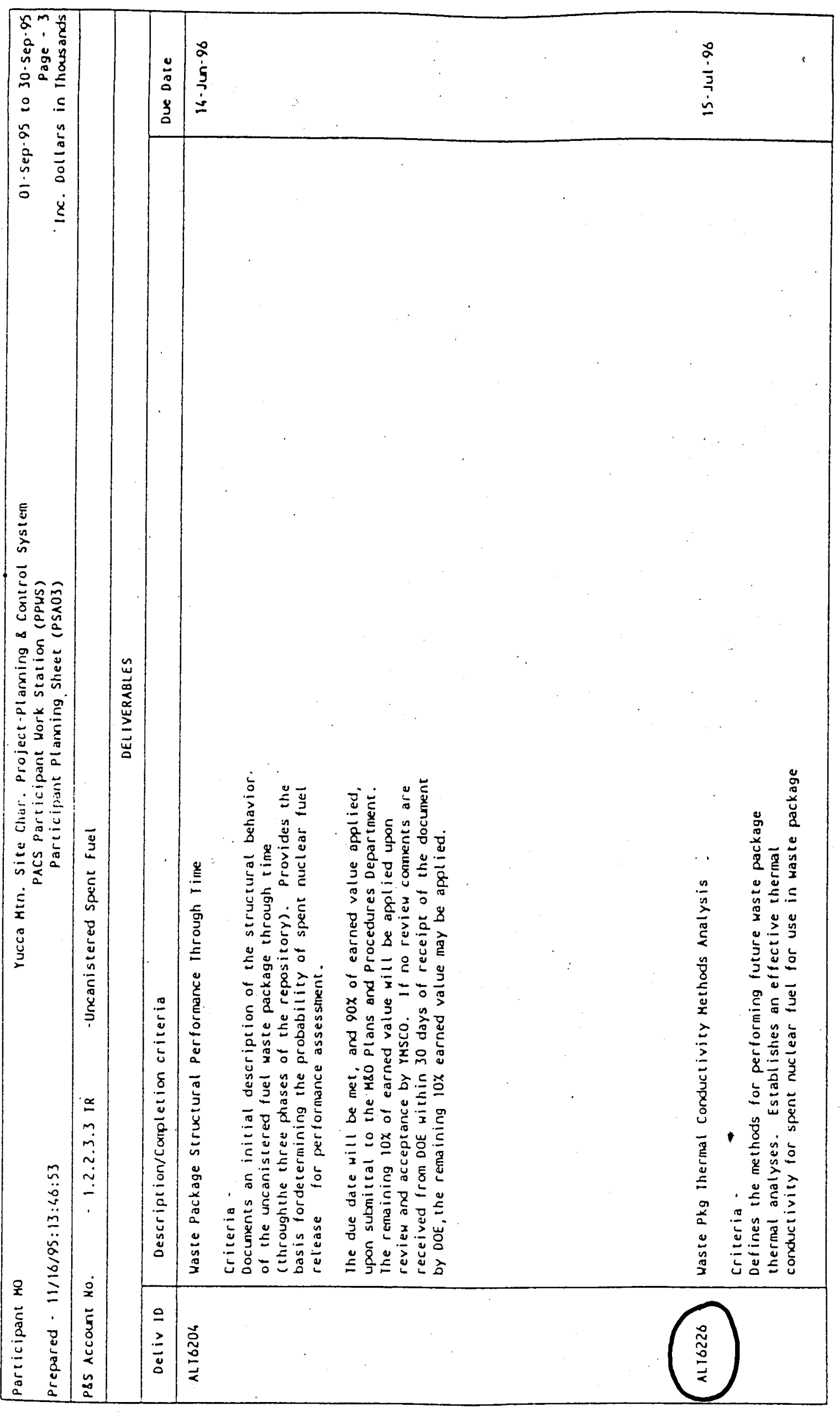




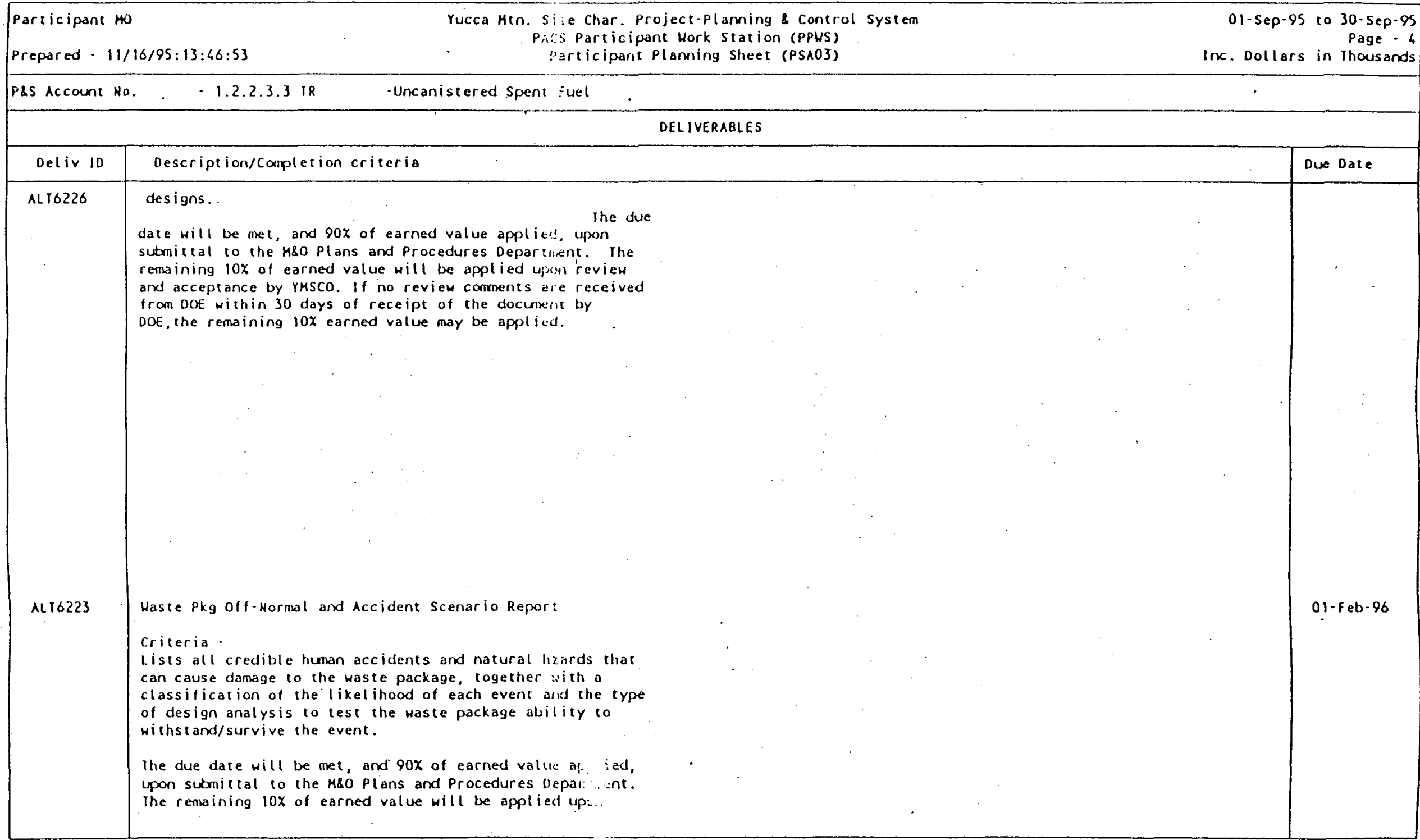




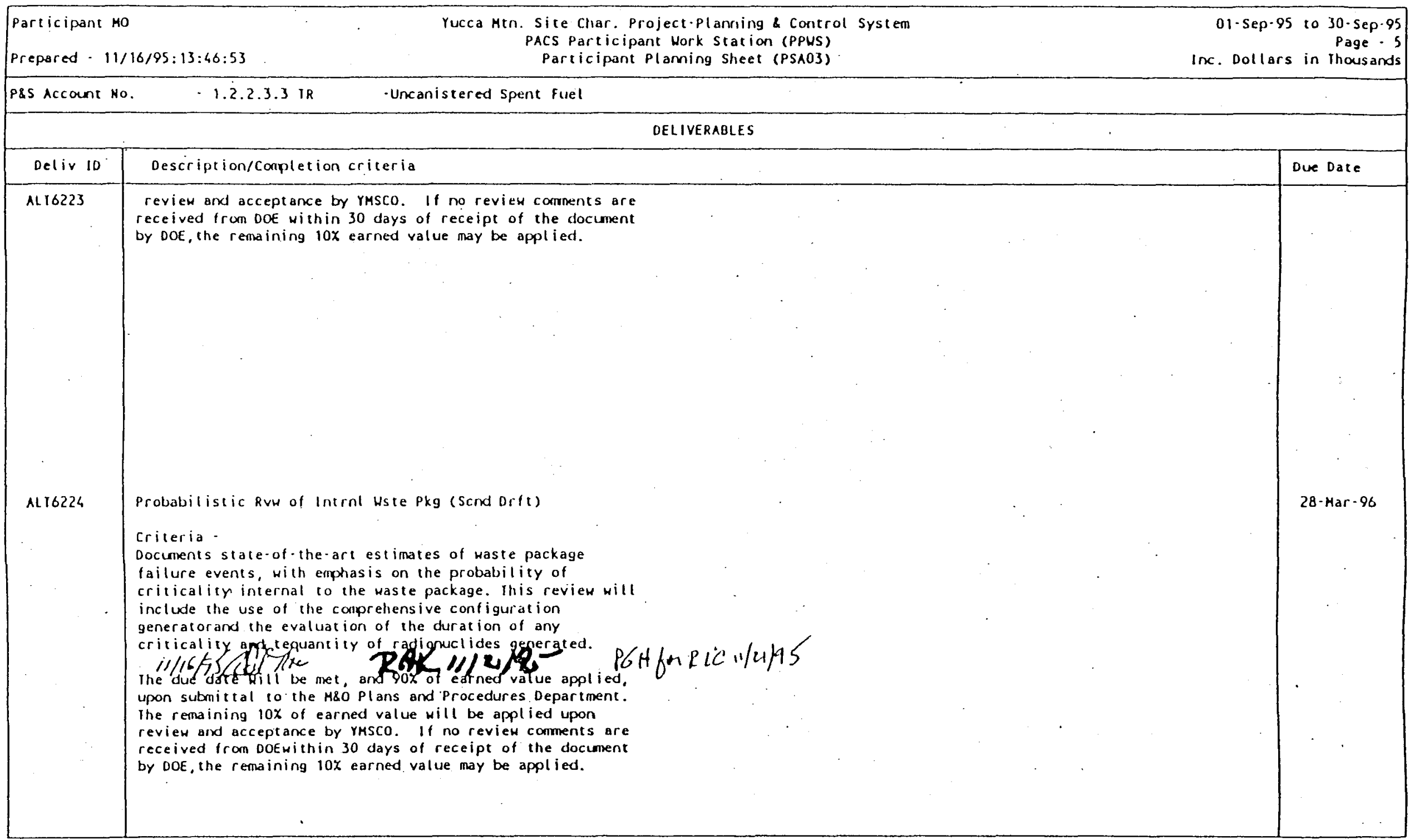




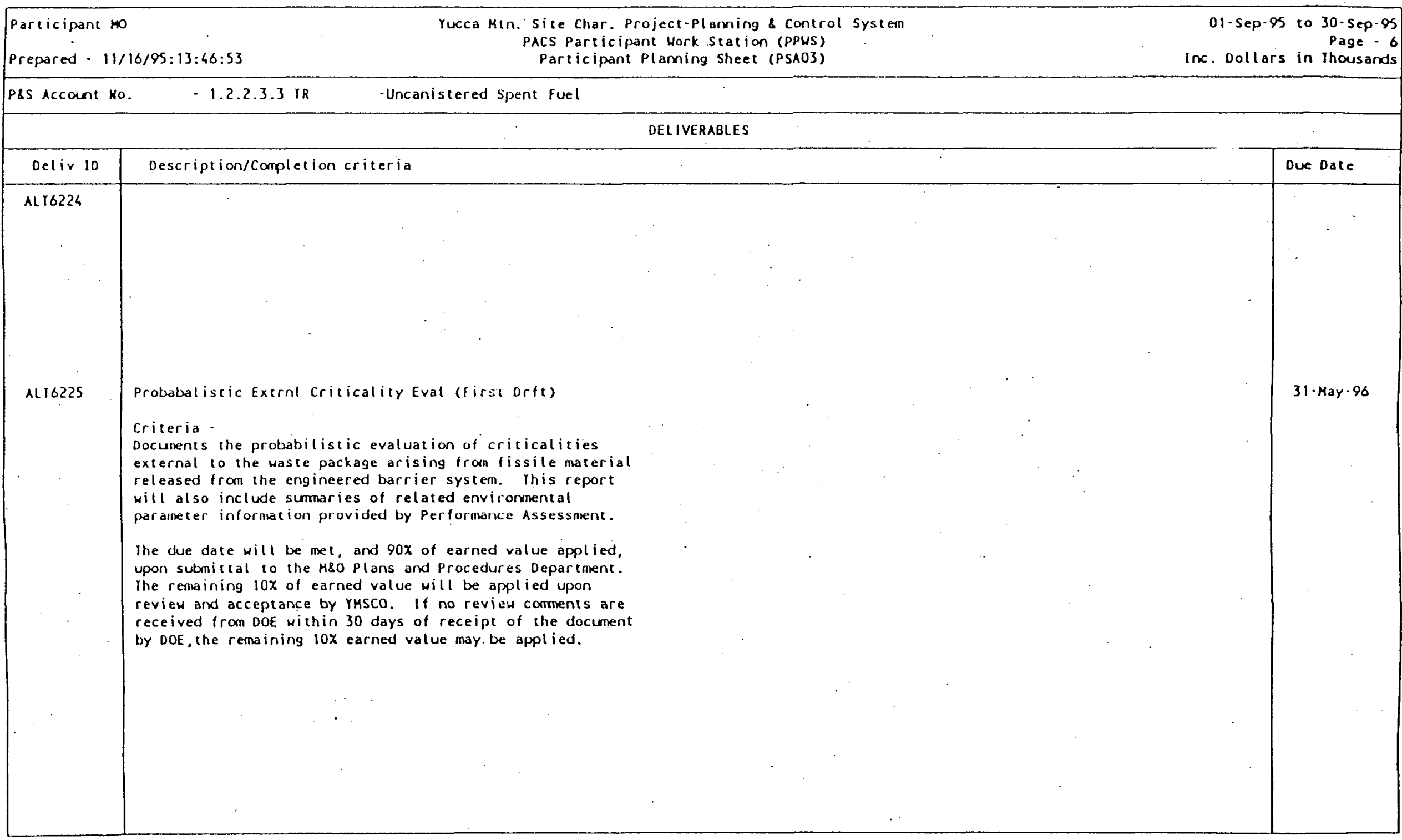




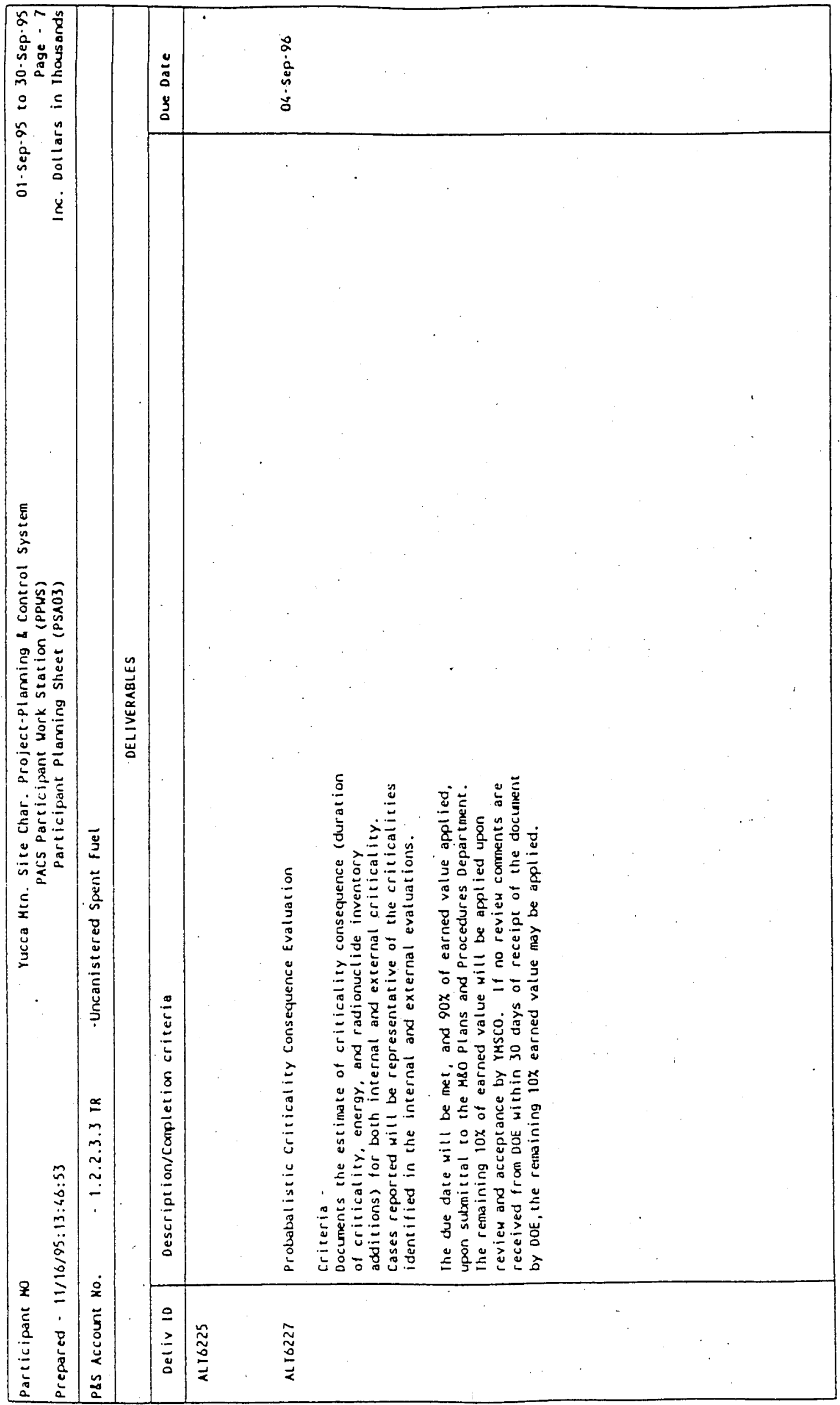




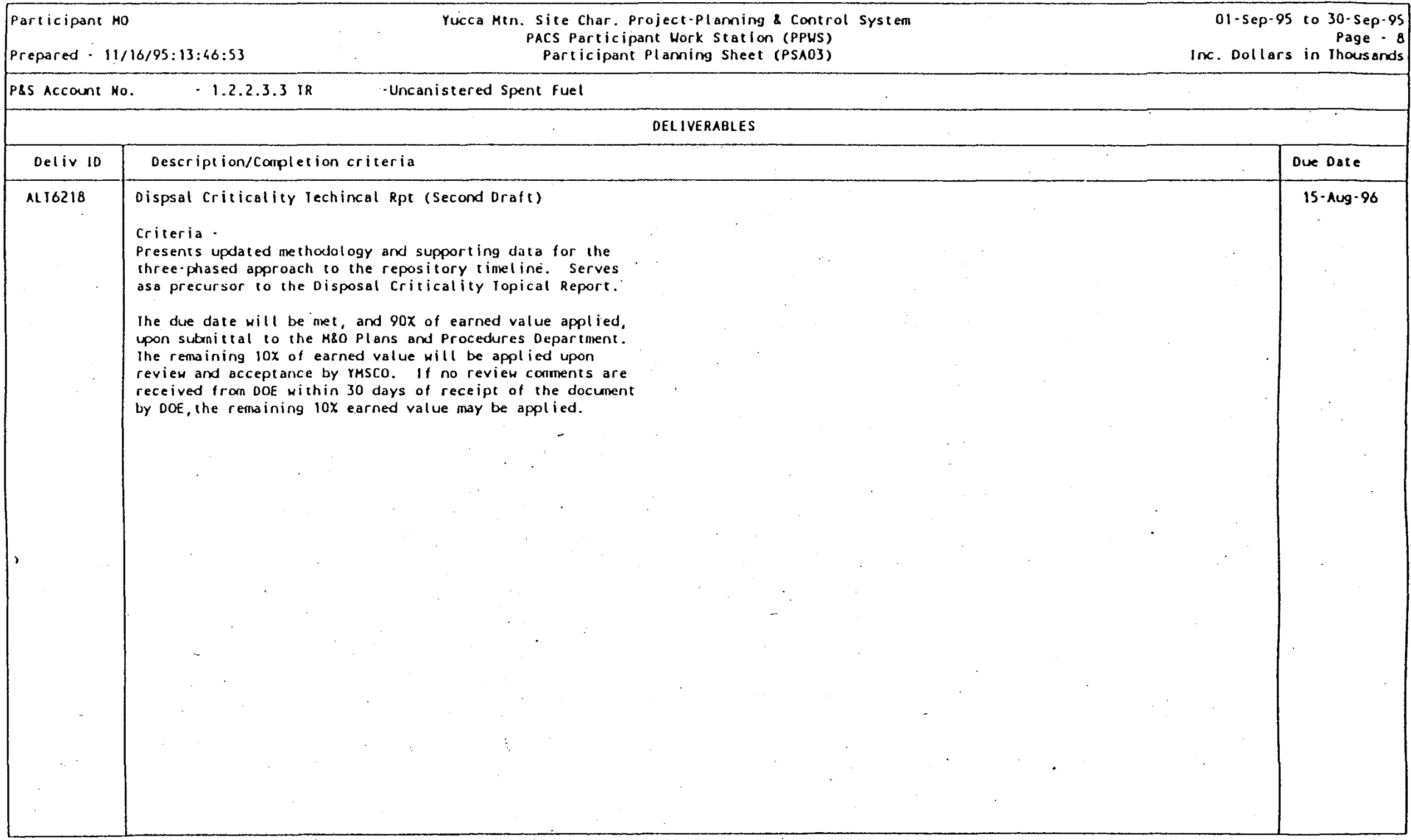




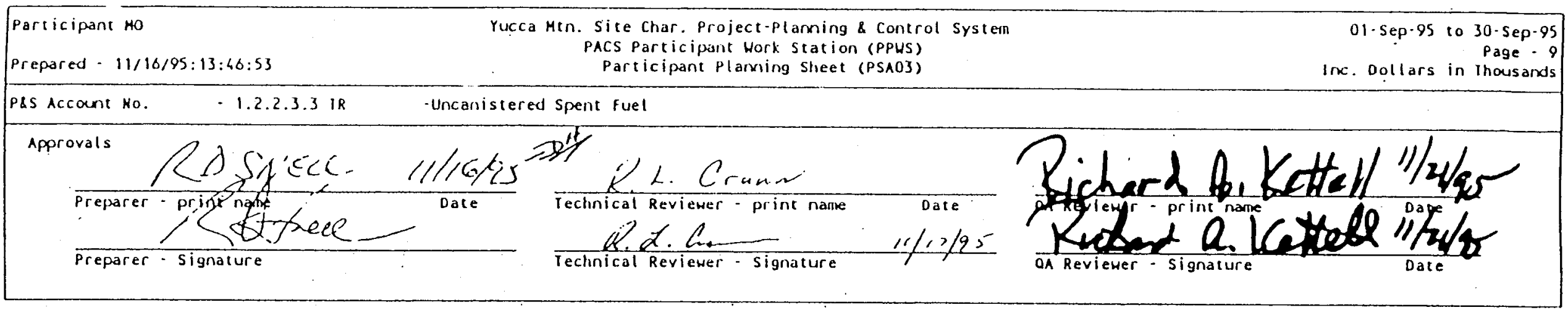

